

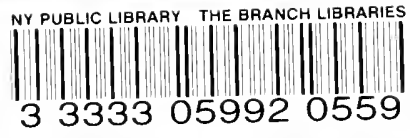

j'58 o hounsberry

5238 Wild flower book 
$580 \mathrm{~h} 5238$

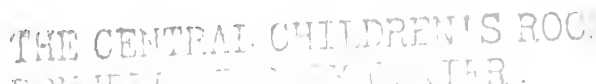

20 yon, $y .20019$ 
$y_{1}^{1} \quad 18$ 


\section{THE WILD FLOWER BOOK FOR YOUNG PEOPLE}





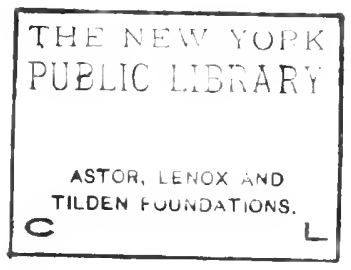




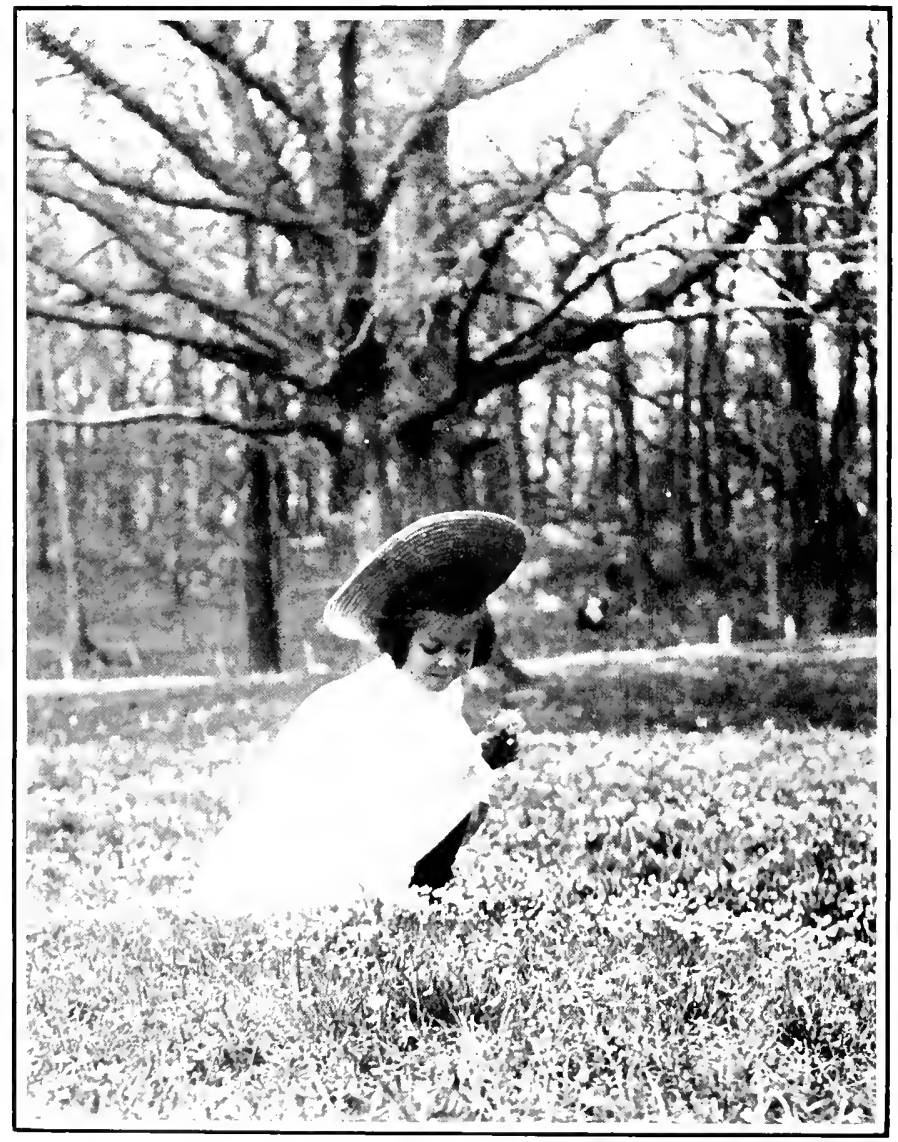

I'LATE V.-WHERE WE FULNI) LITTLE TRUDY 


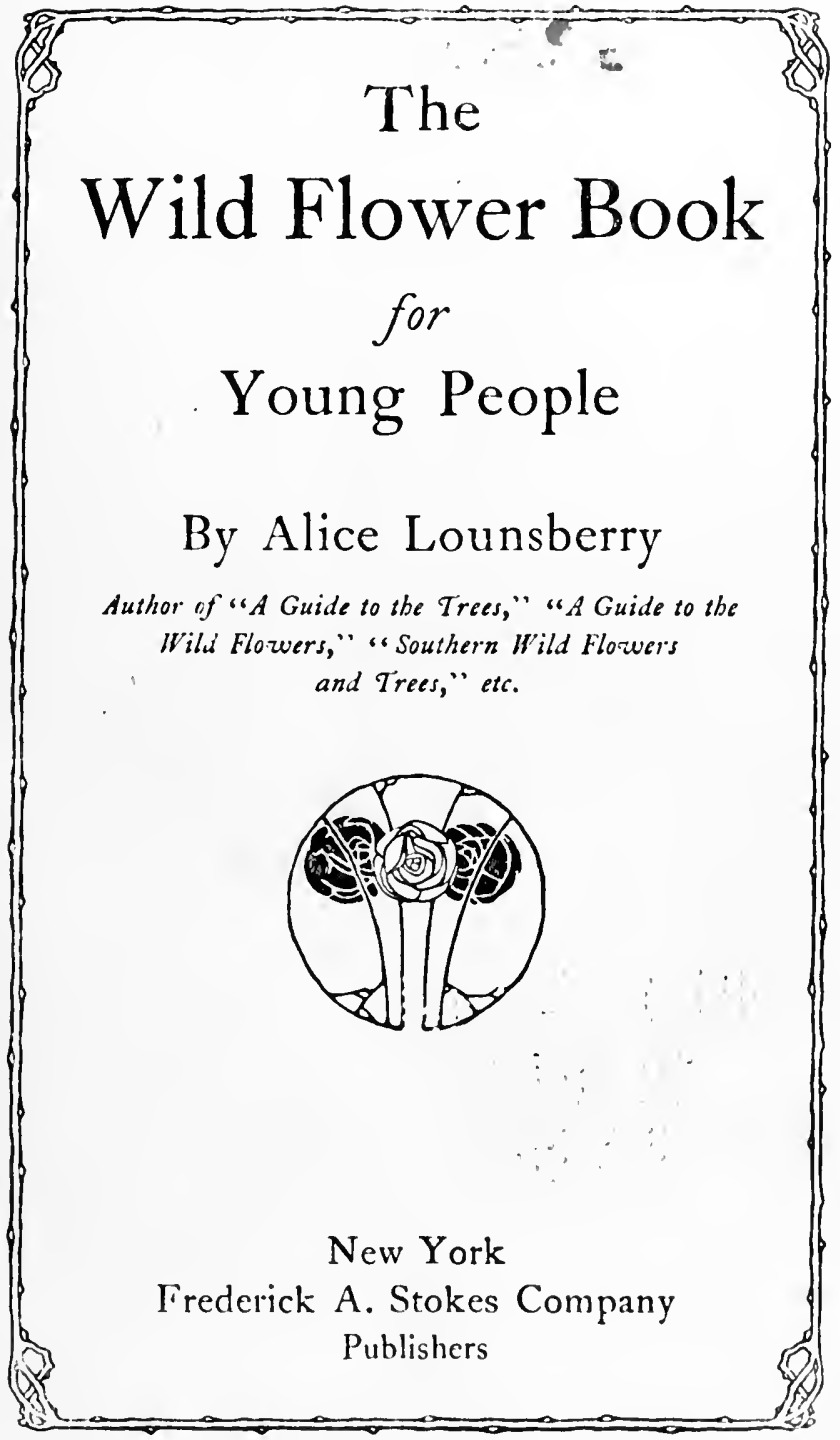




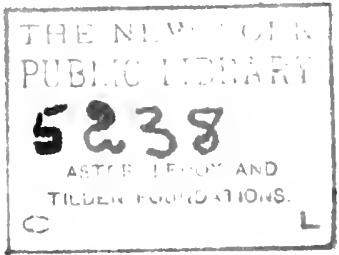

Copyright, 1906, uy FREDERICK A. STOKES COMPANY

This Edition published in August, 1906

All rights reserved

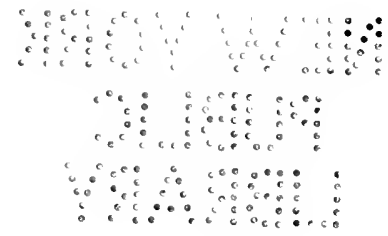




\section{580 L}

To

MY MOTHER

WHOSE LOVE OF CHILDREN AND FLOWERS

LIVES ON THROUGH MEMORY

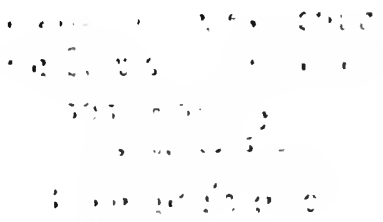




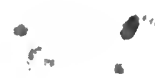

8

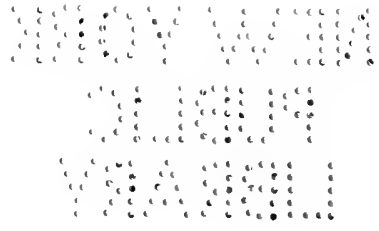




\section{PREFACE}

The little girl who tells this story goes from the city to live in the country with her grandmother. There, through the spring, summer, and the cool, crisp autumn, she roams through woods, meadows and swamps, and sees many things that pique her curiosity. Most often it is the wild flowers she wishes to know about; although she notices the birds, the trees, and even a bullfrog. She sees that the sky changes, and wonders why the dewdrops cling so long to blades of grass.

In her own way this little girl writes about these things, using neither botanical terms nor difficult words.

The flowers she finds are the ones common throughout the northeastern States of her country, where hundreds of them bloom every year near large cities. Now, however, the rarer flowers are moving to places far away from men's dwellings, because they have been picked so much by those who think little of their preservation. She learns that wild flowers have tender feelings, and that they resent cruel treatment, even though they cannot complain in the language of children. This 


\section{PREFACE}

little girl loves the flowers dearly, and listens eagerly to stories told her about them by a boy named Tommy. Indeed, she makes friends with girls and boys in the country, and Dame Nature guides her by various paths to the heart of many secrets.

In this book there are pictures showing a number of wild flowers, and also these bright-eyed children as they played among them out-of-doors.

On some days another author besides the little girl went with the children, tramping across fields and by deep streams. They told her, too, tales about the fun they had together, and showed her places where certain wild flowers bloom each year. They helped her in many ways, and for their companionship, and gay chatter, she now sends her most loving thanks. 


\section{CONTENTS}

CHAPTER

I I go to the Country or of in 1

II Early Flowers and the Visit of Francis : 8

III The Real Spring and Little Trudy . . 17

IV Violet Mysteries . • • • • 22

V The Spirit of Secret Valley . • . 29

VI What Sallie found out about Bloodroots • 34

VII Answers to Francis's Letter - a. 4 I

VIII Jack-in-the-Pulpit and his Friends 47

IX When Dogwood blooms • • : $\quad 53$

$\mathrm{X}$ More Flowers, and why Tommy felt

Ashamed . . . . . . . . 59

XI Columbine's Glory • • • • • 66

XII The Large Yellow Lady's Slipper $\quad$ 10. 73

XIII Old Adam's Gaiety • • to • 80

XIV iThe Find by the Road, and Little Pipes . 86

XV Wild Geranium and Poor Robin's Plantain 92

XVI Philip hears about Three New Flowers - 99

XVII The First Day in June • $\quad$ • to 106

XVIII Little Trudy's Blue Flowers . : : : II3

XIX Professor Bonn's Letter to Philip . . II9 
CHAPTER

XX On Wild Rose s Highway . • . I25

XXI Philip goes for a Bouquet of

Meadow-Sweet • . . . 131

XXII When Berries are Ripe • . . 137

XXIII Letters from Francis and Sallie . . I44

XXIV Helping weed the Pasture . . I5I

XXV St. John's-wort Flowers and Witches' Work

- 158

XXVI When Tommy and his Father were

Afield

- 165

XXVII Philip's Hunt • • • • 172

XXVIII The Picnic on Old Adam • • 178

XXIX White Flowers and a Mischievous

Fairy

XXẌ Finding Odd Flowers . . . . 193

XXXI Midsummer • $. . \quad . \quad . \quad .200$

XXXII The Drive to Great Rock • • . 207

XXXIII Philip finds Flowers but no Girl • . 214

XXXIV In Miss Amelia's Meadow • • . 220

XXXV The Cardinal Flower • • • 227

XXXVI Another Part of the Stream . . 233

XXXVII To Indian Monument • • :

XXXVIII Flowers that have escaped . . . 247

XXXIX Since Autumn has come • • . 254

$\mathrm{XL}$ Joe Pye-Weed, the Strange Girl and

Others • • • • • . 261 


\section{CONTENTS}

CHAPTER

XLI The Studio Favorite and Turtle-Heads . 268

XLII Blue Flowers that come Late • • 274

XLIII Indians in the Goldenrod • • • • 28I

XLIV Concerning Asters • • : : : $\quad$ : 287

XLV Real Autumn . เ. . . .

XLVI Nutting Time • • • • • • 299

XLVII The Dream . • • • • • 306 


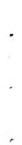




\section{LIST OF ILLUSTRATIONS}

I "He was going up a tree when I saw him first" • • . • • . . • 4

II "It is like them in looks and yet a little different" • • • • : • • • IO

III Dutchman's Breeches . • • IV Early Saxifrage • • • • • • 18

V Where we found Little Trudy - Frontispiece VI "After we had started" • . . . . 24 VII Early Blue Violet, Downy Yellow Violet,

Common Blue Violet • • . . 26

VIII Secret Valley . • • • • • •

IX The Spice Bush • • • • • 32

$\mathrm{X}$ Bloodroot • • • • • • • 36

$\mathrm{XI}$ "'His ears were lifted up and he looked surprised to see me'” • • • • 38

XII Spring Beauty • • • • • $\quad 4^{2}$ XIII The Large-flowered Wake-robin • •. 44 XIV Jacks in the spring woods • • • . 48 XV Sallie and Dogwood . • • . . 56 ix 
PLATE

XVI "They were woven together'" . 64

XVII Wild Columbine • • 68

XVIII "There was only one flower" - -76

XIX Rock Pinks . - * is 80

XX Good-bye to the Rock Pinks .. เ: 84

XXI Pink Azalea * * * 86

XXII Naked Broom-rape, or "Pipes" 90

XXIII Wild Geranium and the White Fern • 94

XXIV Poor Robin's Plantain • • *. 96

XXV The True and the False Solomon's

Seals . . . • * $\quad .100$

XXVI False Lily-of-the-Valley • • • 104

XXVII "Little Trudy was in the swamp" I. I Io

XXVIII The Larger Blue Flag • • . II4

XXIX Philip stops on the way by Rocks like

Steps • • • • • • • 120

XXX The Four-leaved Silkweed . . 122

XXXI Wild Rose . . • • • . 126

XXXII Talking to Wild Rose . • เ. . I 28

XXXIII Meadow-sweet • • • $\quad 132$

XXXIV When Gentlemen meet • • • 134

XXXV Tommy's Seat • • • • • I40

XXXVI "First he ate one, then he gave me one" . . . . . . . 142

XXXVII "She stops to pick Daisies on her way home" . . . . . . 148 
XXXVIII "Tommy lay down in the grass" . 154 XXXIX "A few Daisies and Buttercups and

Black-eyed Susans in my basket" . I56

XL "The witch held out a piece of St. John's-wort" • .. $\quad$ • : $\quad$ • 164

XLI Spreading Dogbane i. (เ) (1) 166

XLII The Strange Girl among the Wild Lilies

- 170

XLIII Starry Campion . . is:

XLIV Bulb-bearing Loosestrife • • . I76

XLV Wild Bergamot • . . . . I 84

XLVI The Ghost Flower and its Neigh-

bors . . . . . . . 186

XLVII Prince's Pines and the Queer Flower 190 XLVIII Rattlesnake-weed • • • • • 194 XLIX The Monkey Flower • • • 198

L Sallie in a Bush of Sweet Melilot . 200

LI The Downy False Foxglove • 204

LII "A girl was lying among the pink blossoms" • • • • • . 212

LIII "He sat down among the flowers" . 218

LIV Moth Mullen . .. t. . . 224

LV Simpler's Joy • • 1. •. 226

LVI The Cardinal Flower . • • $\quad$ • 228

LVII "He walked back by the little path" . 230

LVIII Butter and Eggs . :- : • . 234 
LIX "Kate Hood walking through the Purple-spiked Loosestrifes" . . 242

LX Wild Phlox and Rubber Plant • . 248 LXI Everlasting, or Sweet Balsam • . 254 LXII Roadside Thistles . • • • . 258 LXIII Joe Pye-weed • • • • • • 262 LXIV Milfoil and Boneset . : • . 264 LXV Wild Carrot • • • . . . 270 LXVI Turtle-head . • • • • 272 LXVII Great Lobelia . • • • • . 276 LXVIII The Old Rock • • • • 278 LXIX Goldenrod • • • • • 282 LXX Indians in the Goldenrod • • 286 LXXI Michaelmas Daisy • • • • 288 LXXII New England Aster and Blue Aster . 290 LXXIII Little Trudy with Wild Sunflowers . 294 LXXIV Pokeweed . • • • • . 296 LXXV Witch-hazel • • • • • • 302 LXXVI The Large-leaved Holly . • 304 LXXVII The School-house in the Woods • . 3ro 


\section{The Wild Flower Book for Young People}

\section{CHAPTER I}

\section{GO TO THE COUNTRY}

I kNOW nothing about this beautiful country where we have come to live; only that it is away from the city and the friends who went to school with me there. It is chilly and no leaves have come out yet on the trees. But then it is only March.

Our house here is not nearly as pretty as the one we have left in town. My Grandmother calls it forlorn; so it must be the wild flowers when they are in bloom, and the country round about that she thinks I will learn to love so dearly.

When Grandmother was a little girl no older than I am she lived in this house; and still remembers a great many places where wild flowers grew, and birds built their nests. She can tell wonderful stories about flowers, and how they have ancestors and relatives just like the people in history.

One thing already makes me happy here which in the city I rarely saw at all, and then only as a roof over the high buildings. That is the blue sky. In the evening it is filled with shining stars. From our veranda on clear nights we can see besides that it is far away and very wide; and I have often wondered if some one up in the heavens lit 
thousands of little candles, and then went about snuffing them all out before we awoke in the morning. When I asked Grandmother if this could be true she smiled, but said that I was not thinking in just the right way about the stars. They are always there, she told me, only we cannot see them until it grows dark.

Although it is still too cold for wild flowers to open, ever so many little birds are piping and singing. Early in the mornings they fly to a tree near my window, and there they make so many chirps and give such long, sweet calls to each other that I spring out of bed to run and look at them. I see birds with blue backs, and many that are all brown, and some are smaller than the others. Numbers of them have bits of straw or grass in their mouths, and this makes me feel sure they are nodding and whispering about building nests.

Just below the side of our house there runs a stream. One day on its bank I saw an odd looking creature. In parts he was as green as grass, his eyes bulged out, and his voice sounced as though he had a very bad cold. I knew at once that he was a bullfrog, but I did not know, until Grandmother told me, his reason for croaking. It was because spring had come. I often saw him after this, but he usually jumped right in the stream when he heard my footsteps. He was not sociable.

Another day a little farther along the stream 
I met a boy, and later we became real friends. He was going up a tree when I saw him first, and I shouted to him to know the name of his dog, who didn't seem to like my being there. He quickly slid down the tree, calling, "Here Peter, here Pete." I asked him his own name, and he said it was Tommy, that his father's name was Tom, and their cat's Old Tom. This I thought very strange, as the cat is younger than either he or his father.

Tommy said he had a notion a crow was beginning to build in the tree he was just shinning up, and that he wanted to mark it, so as to get one of the young birds to tame. He said that he could do this any day though. He seemed to know that I was the little girl who had come to live in the old house, for he told me his father knew Grandmother, and that he lived in the next place. It was Saturday, so he wasn't at school.

Tommy told me that very morning that he loved wild flowers, and that he knew most of the places where they grew. These places he calls "bunks," and those of very rare flowers he seldom talks about to anybody. But he is not hunting much for flowers now, it is too early; he tries to see little green things, like tiny spears of grass, or bits of moss just the color of emeralds. Besides, he is keeping his eyes open for the Skunk Cabbage. Just as soon as the days are really warm I shall have little time for dreaming; there will be so 
many things for me to find out-I mean real secrets about the wild flowers. Perhaps I shall have adventures while hunting for them. When Grandmother was a girl she says she thought life in the spring was most exciting.

It is very fortunate that I called out to Tommy that morning, for he often comes to see us now, and Grandmother says that he is "reliable." Yesterday we walked down the side of the stream to where little low trees were leaning over its edge, and looking as though they might take a tumble any minute. There were no more leaves on them than on any of the other trees, but along the sides of their twigs little buds were sticking out as soft and gray as the back of a pussy. I ought to have known that these were Pussy Willows, for I had often seen them for sale, tied in bunches; only here they looked so much softer and grayer, holding tight to the bare tree.

Tommy finds fewer of them every year, because they are picked by many people to sell; and some day he thinks they will only dare to peep out miles and miles away from houses and trolleys.

"So you found Pussy Willow to-day?" Grandmother said in the evening. "Next you will come telling me all about Skunk Cabbage."

We had seen this plant the very first day it pushed a spike of green through the ground; Tommy was showing me the swampy place where it grows every year. Since then, as we told Grand- 


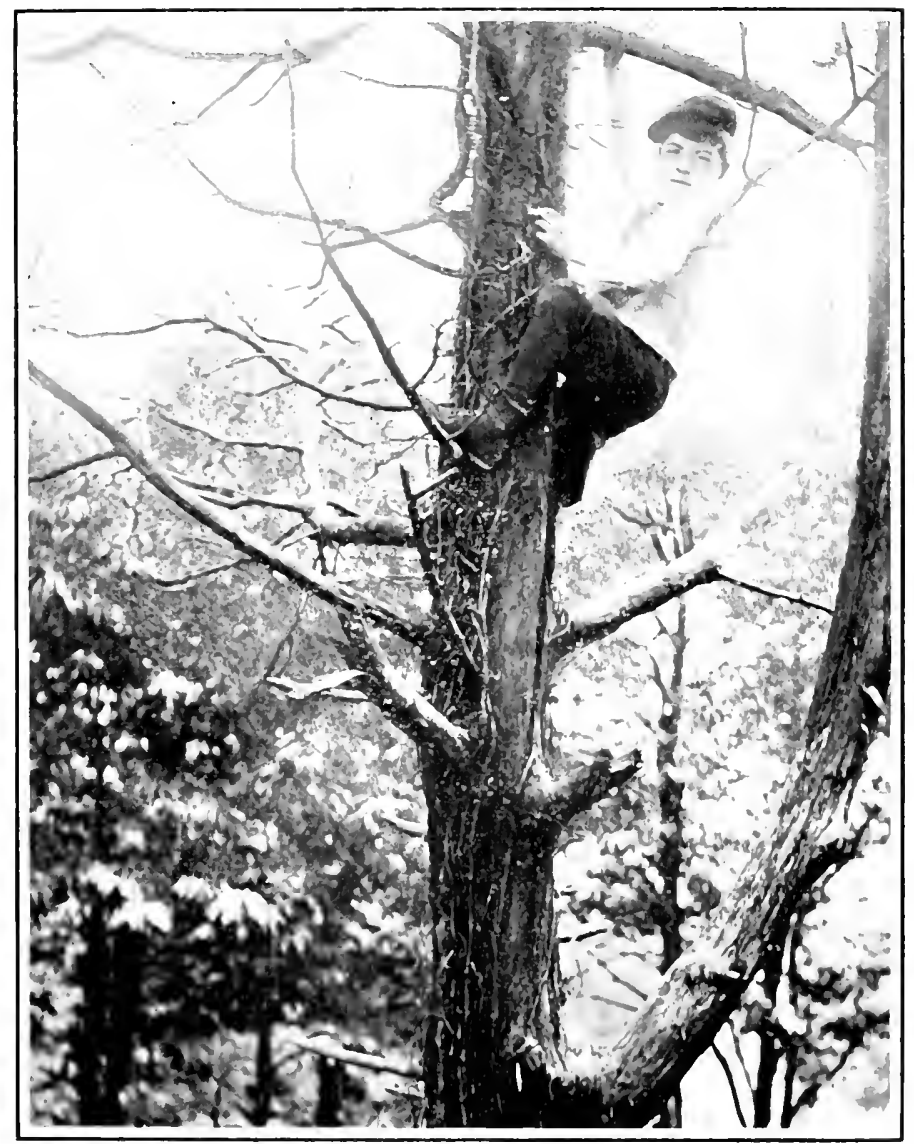

PLATE I.-" HE WAS GOING UP A TREE WHEN I SAW IHM FIRST" 


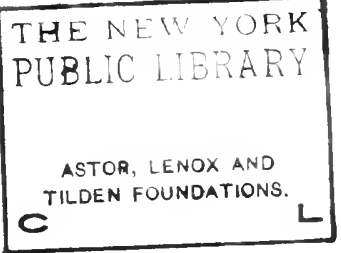




\section{GO TO THE COUNTRY}

mother, we had watched the spikes unfold until they looked like little green and purple hoods. Inside each one there stands a piece like a stick with hundreds of tiny florets growing about its sides. The hoods, Tommy says, are just to protect these florets from cold and wind. He laughed when I picked one of them, and then threw it down because it smelled like a mustard-plaster.

"There'll soon be other flowers much better than that to pick," he said, "only by the time they're here Skunk Cabbage will have lost its hoods, and its great green leaves will begin to make this swamp look like a cabbage-patch."

Each day in the country now there are so many surprises that it seems quite as though we had come to live in fairy land, only things don't vanish here when we awake in the morning. Everything is real.

At last there is one beautiful little flower above the ground. This morning Tommy took me out to look for it. Its name is Hepatica, or sometimes he calls it Blue Eyes. He had picked four white, three blue, and a pink one before I had found any. His eyes are sharp. But when I pushed aside some dried leaves with a stick I also spied a few, full open and blinking in the sunshine. The Hepaticas are such dear little flowers. They grow in groups together and don't seem to mind having no other playmates than dead leaves. I wondered if they felt something as I did when 
Grandmother gave me my fur collar and muff at Christmas. For all along their stems, and on the green leaves under the flowers, there is surely a soft and silky fur. I was so curious to know if it made them feel warm that I slipped my finger all around their stems, thinking perhaps I might find out for myself if they were warmer than the dead leaves.

Tommy says it is all a made-up story that flowers ever speak, but sometimes I have my own thoughts about them, and like to play I hear the Hepatica saying:

"Once there was a little girl who was grieved when she saw me; grieved because I wasn't a Violet. She had lived all her life in the city, and thought that the Violet was the first spring flower. She didn't know that the Violet could never come out as early as I; for its stems are covered with no warm fuzz, and its leaves have not stayed green, and snuggled about it, and kept it warm all winter. When the little girl found all this out she called me very brave, and loved me for my own sake. She might have stayed with me a long time in the wood, only she wore a little ticking thing on her dress, and whenever she looked at that she said it was time for something."

Just then I looked at my watch. It was surely time to go back to Grandmother, so I up and ran home, making a great noise in the dried leaves.

In the evening Grandmother told us that $\mathrm{Mr}$. 


\section{GO TO THE COUNTRY}

Hamilton Gibson, a very great botanist, had sometimes found these little blossoms as early as the last of February.

Since then Grandmother showed Tommy and me how to make a bird's nest basket with moss and Pussy Willow. This was not difficult to do, for Tommy had a little basket that some figs had come in, almost the shape of a bird's nest. First Grandmother laid moss all around its outer side, and fastened it well with a needle and long black thread; and the twigs of Pussy Willow were so soft that she could bend them to make the handle of the basket. Afterward we slipped more of them in and out through the moss, so that they might imitate tiny twigs, bits of straw, and the strings that birds carry when nest building. We sprinkled it then with water, thinking it would keep fresh for many days.

When all this was done we laid our bunches of Blue Eyes in the conter, making believe they were eggs.

Then Tommy asked: "What next?" 


\section{CHAPTER II}

EARLY FLOWERS AND THE VISIT OF FRANCIS

When I lived in the city, I never knew that great, gray looking trees were ever covered with tiny flowers, yet in the country in April this is plain for any one to see. All the little twigs have now a lively look; but by far the prettiest blossoms are hanging from the Red Maples. No one could ever count them, there are so many; and they are far too high for me to reach. Still I can see that they are something like tiny, crimson bells with very many yellow clappers. From a distance they make the trees look as though pink clouds were paying them a visit. Tommy says he always keeps half an eye toward the sky when hunting for flowers, and I feel sure this is how he learns so much about tree blossoms.

There is no longer any need to push aside dried leaves when hunting for Hepaticas. They stand up boldly for any one to see. I think that perhaps they were lonely in the woods, for just a few days ago some other little flowers came beside them. Tommy was at school and Grandmother was busy when I found them first, so if any one helped me it was Tommy's dog, Peter, although his master still thinks he was just turning out some snake hole. 
For some time Peter didn't like our coming to live in the old house which all his life long had bcen closed; but now that he has grown used to us, he runs and plays with me just as he does with Tommy.

Peter is a great hunter, and knows every woodchuck hole in this county. His legs are long, and he can run very fast. The morning he went alone with me into the woods he trotted on, always a little way ahead, and then turned around sometimes and barked to ask if I were coming. I thought perhaps he had something to tell me, and twice I called him back and said: "What is it, Peter; what is it?" But he only wagged his tail and ran on.

When I stopped to pick some Hepaticas, he came back of his own accord, looking over the ground for something. Then suddenly he put his nose in a hole and began tossing up the earth and leaves in a hurry. I ran to see what he could be doing, and there just by his shaking head were four little white flowers. Their names I now know were Wind-flowers, or Wood-anemones.

Just one delicate blossom grew alone at the top of each stem, and they were not solidly white, for two were tinted with blue, and the one on the tallest plant was quite pinkish. The green leaves underneath the flowers were divided into five, sharp, little parts; and those that were not quite open had a pinched-together look. 
These flowers were rocking to and fro in such a gale of wind that it seemed strange they were not torn from the earth and carried away. I wondered for some time if the wind sought them out to play with, and if this could be why they were called Wind-flowers. Indeed Grandmother says there is an old story that Father Wind blows them open, and then blows their petals away, so it is quite reasonable that they should bear his name.

I think perhaps flowers love the wind just as much as they do the sun. The wind is so lively; it hardly keeps still a minute. Sometimes it makes sounds that are low and sweet, and it touches the flowers gently; or else it is very mischievous, tossing dead leaves in the air, and carrying the flowers' pretty leaves away. But when it is really angry, it howls and roars and bends their stems almost double. The wind, though, is very kind to the flowers. After they are wet by the rain, it blows against them, and dries them quite nicely; and when their seeds are ready to be sown, the wind lifts them up and carries them off, and puts them down in some little bed of earth where they can grow. I'm sure now that the wind is wise and useful, although when I lived in the city I thought it only cared to blow my hat off.

Now so many Wind-flowers are blooming in some places that I must take long jumps so as not to step on them. What also seems curious to me 


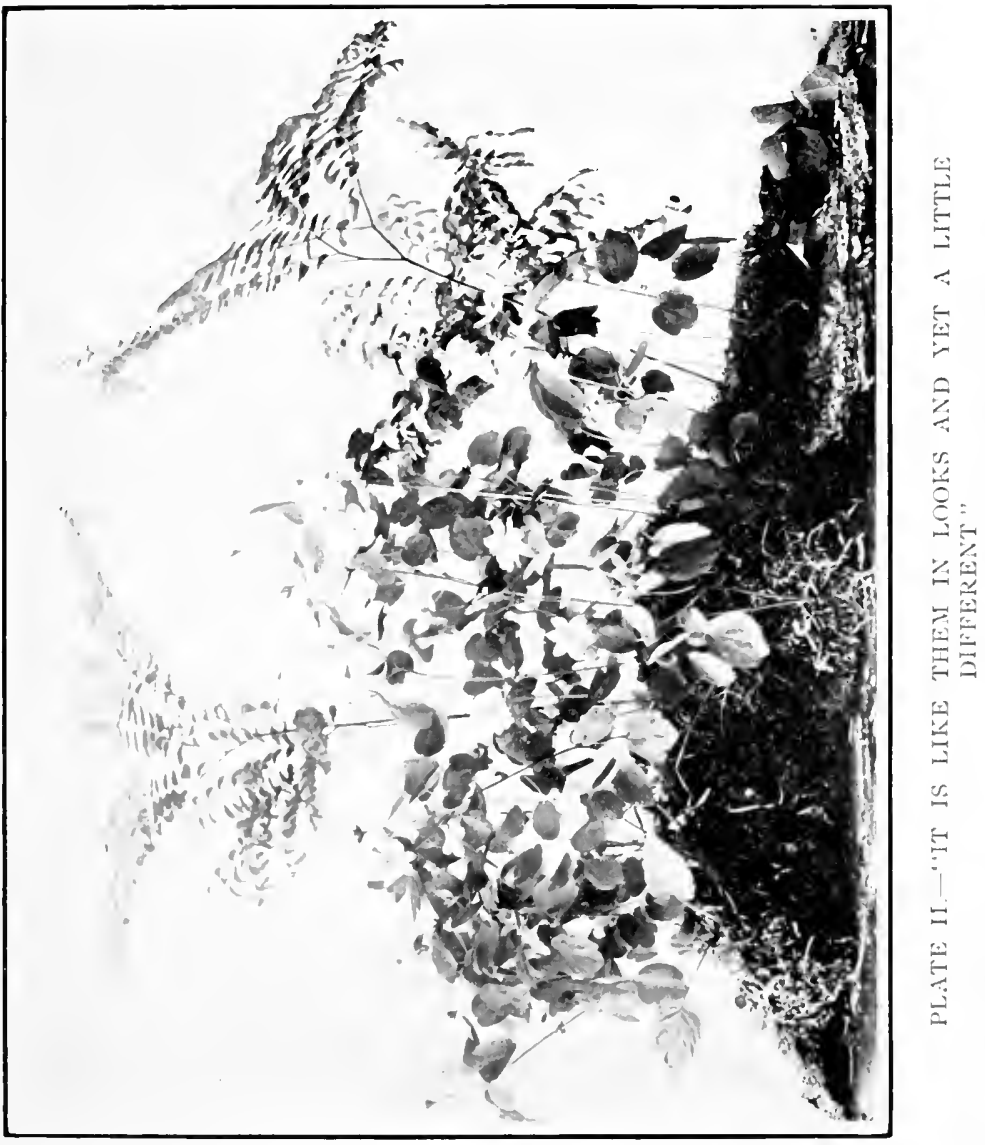




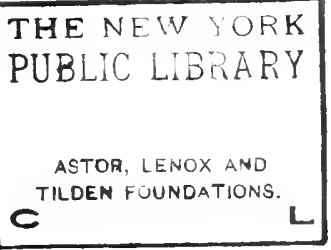


is that another little flower has come by the Windflowers. It is like them in looks, and yet it is a little different, and is called Rue-anemone.

At the top of its stem it sends out little, white flowers, all very much like the one blossom of the Wind-flowers. Its green leaves are round, and notched in three places, and very thin and smooth. It is a cousin of Wind-flower's, so perhaps it is not strange they should look so much alike. One beautiful, little company of them grows in a clump of thick moss; and two Maidenhair Ferns stand up over their heads. Perhaps they wish to shade the flowers.

The part of the woods where we find Rue-anemone belongs to Tommy's father. He wishes no one to pick it, because, he says, it is very easy to drive it away even from places that suit it well. It vanishes when it is torn up by the roots, or abused, and only a great deal of coaxing will bring it back again. It is like the buffaloes that Grandmother has told us about. Years ago, she says, there were many of them in the great west of this country. But then people lassoed them, and killed them for their skins in such numbers that they left the places near where white men were making cities and towns; and after a while there were only a few of them left anywhere.

So it is a pity to take Rue-anemone from its cool, shady home. Everything there helps to make it beautiful, even the insects, and a bright, little lizard 
I saw not far away. And when it is picked its leaves curl up soon, and it dies.

One day Tommy found quite a large bunch of Maidenhair Fern that had been taken from their woods, and thrown down later by the roadside. This had been done by some one because it was fading; some one who cared more for picking flowers for the sake of picking than for the flowers themselves.

In the rock's crevices, and in dry, sunny spots of the woods, there is still another flower blooming. Tommy calls it Dutchman's Breeches. It is white, tinted a little with yellow, and shaped quite differently from any other wild flower that I have seen. Just now I cannot think of anything exactly the shape of these little flowers. Some people think they look like Soldier's Caps, and others call them White Hearts. They are not a bit like Dutchman's Breeches, unless these should be closed at the bottoms, and turned upside down. It is easier, I think, to describe the leaves, for they are cut into many slender parts, and look like ferns.

After Tommy had found the first Dutchman's Breeches that opened we tried to think of another and prettier name for them. My choice was Butterflies' Banners. No one knows exactly the shape of such things, but perhaps butterflies could think of nothing better for banners that these little flowers. Tommy had found them by the great 


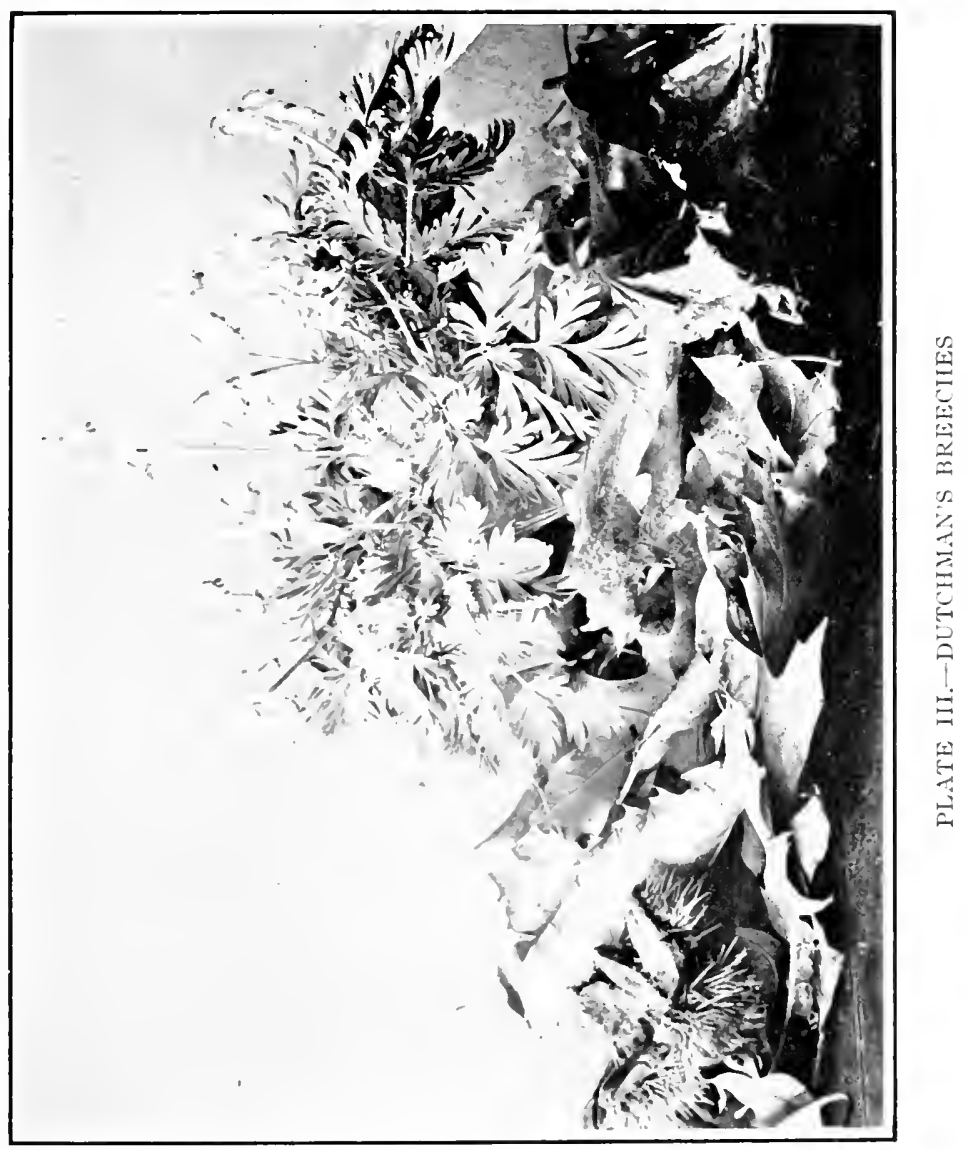




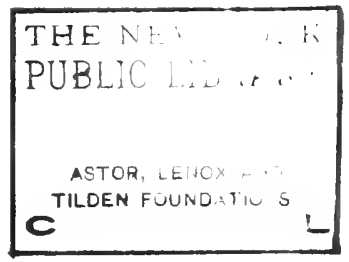


rock in the woods he calls Adam, because it is so old.

That very afternoon my cousin Francis came from his home in New England to visit us. $\mathrm{He}$ is a fine boy, just Tommy's age. When he jumped from the carriage, I saw that he had a little box in his hand, and once he was going to give it to Grandmother; but she had a visitor just then, so he kept it by him closely.

When I introduced Tommy to him, saying that he loved flowers, Francis threw the box down on the table, and put his head back, as much as to say: "Match that if you can."

In the box there was a little bunch of Trailing Arbutus, or Mayflower. Its scent was like the dew on the ground, only far sweeter. Of course Tommy knew he could not hope to find it near his home, and he said so at once. Then Francis said we had no other flower half so pretty. Now' Tommy is very proud of the flowers that grow around here, and he felt angry. He said nothing then to Francis, but ran out and brought in the few Dutchman's Breeches he had picked in the morning.

"Isn't that a more beautiful flower?" he asked. "Look at its fern-like leaves and see how curious it is."

"No," said Francis.

"You think those stiff leaves of your flower pretty?" asked Tommy. 
"The flower is pretty," said Francis.

"This flower has a particular insect that visits it," argued Tommy.

"This flower was the first to welcome the Pilgrims to this country," argued Francis.

"This flower-" said both together.

It was fortunate then that Grandmother came back to the room, since Tommy and Francis were growing red in the face.

"My boys," she said, "each flower is beautiful. Francis, you may not know that once in New York State the Arbutus grew in many places, even close to the largest cities. It snuggled up against wooded banks, and spread thick patches of glossy green leaves, and pink-faced blossoms in sandy spots where the sun shone brightly. It was so sweet, and so much more charming than its companions that people from far and near picked it in great quantities. Many took it also and tied it in bunches to be sold on the streets.

"Even the people who thought they loved it paid little heed to its welfare. They picked it most carelessly, tearing it up from the ground by its slender, running rootlets. The Arbutus blossom, as you know, has but a short stem of its own, and to pick it with care is slow work. But even so, the plant has been a long time growing, and when its young shoots are torn off more than a year's labor is destroyed.

"So it was that the patches about here became 
smaller each year, and lost besides their lusty, vigorous look, until now they have entirely vanished. Tell this story, Francis, to those about your home, so that the same thing may not happen in the land of the Pilgrims."

Grandmother spoke most seriously. Francis answered that near his home the Arbutus spread such large sheets of bloom over the ground that people might pick for a hundred years and still it would be there. Again Grandmother cautioned him to pick it with great care. Then Tommy, who had really been still for a long time, said:

"Dutchman's Breeches is vanishing. Not because it is much torn up by the roots; its bloom is easier to pick than that of the Arbutus, and of course it does not spread itself by running under the ground. It is because most girls and boys gather as many flowers as their two hands can hold, and never think of leaving a few on each plant to be fertilized by insects, and to form and sow seed."

"Indeed," said Grandmother, "we should never prevent plants from attending to that matter. It is one of Nature's great laws."

Francis and Tommy asked Grandmother many questions about how flowers make their seed, and about their friendship with the bees and butterflies. She said she would answer them all another time, because then we were soon going to have dinner.

It was so cool in the evening that we sat by the 
wood fire in the library, and Francis told Grandmother and me a story about a Ghost-flower. $\mathrm{He}$ thinks I may find it here in our own woods, although there is no use looking for it before July. If I find it then, I'll remember to repeat the story. 


\section{CHAPTER III}

THE REAL SPRING AND LITTLE TRUDY.

IN the sunshine now it is really warm. The gardener has given up saying that there may yet come a frost to catch the impatient blossoms, and Grandmother no longer urges me to wear my winter coat. Tommy seems excited by these real spring days, and has hardly time to talk with Peter. He is busy keeping watch on the crow's nest, and many little flowers which, he says, are as timid as fairies, and wait for no one.

It was the day Francis went away that we had our first talk about Early Saxifrage. Tommy had picked a small piece of it to put in a bouquet for Francis with Hepaticas, Dutchman's Breeches, Anemones, and Dog's-tooth Violet. But Francis, who was pleased with the other flowers, asked him to take the Saxifrage out because he said it wasn't pretty.

Now both Tommy and I think it a dear, fleecy little flower, only as Francis was going home, Tommy did as he asked without a word. It was not until after we had seen him off at the station that Tommy told me he was sure Francis would be an artist when he grew up, as he mostly cared for things that pleased his eyes; and that although he didn't like the Saxifrage, he could 
see beauty in many things that other people thought ugly. I know besides that Grandmother thinks Tommy will be a naturalist.

"The reason I care so much for Early Saxifrage," Tommy said, "isn't for its looks, but because it's such a useful little plant, and about as brave as Hepatica. It only asks for the least little bit of soil to grow in, and often none at all, as it comes up in rock crevices. There it pushes its tiny roots around until it causes strong rocks to crumble. As they fall away they make more soil. I've heard, too, that all the relatives of the Early Saxifrage make themselves useful to the earth in this same way."

I thought it very fine indeed of the Saxifrage to work so hard because, like Francis, I believed flowers were only meant to be pretty, and grew for us to pick. I never had heard before of their helping to make soil. But I'm sure Tommy is right, and that this is perhaps one of Mother Nature's secrets which he has found out.

Another of these secrets I found out myself, and I think it disappointed me a little. It was that Dog's-tooth Violet isn't a Violet at all, but a small yellow bell, something like a baby lily. Tommy had been telling me to watch for it down by the stream, and had showed me its soft, green leaves covered with purple spots as they stood up straight about some old trees. It is there that the greatest number of them are found blooming, and 


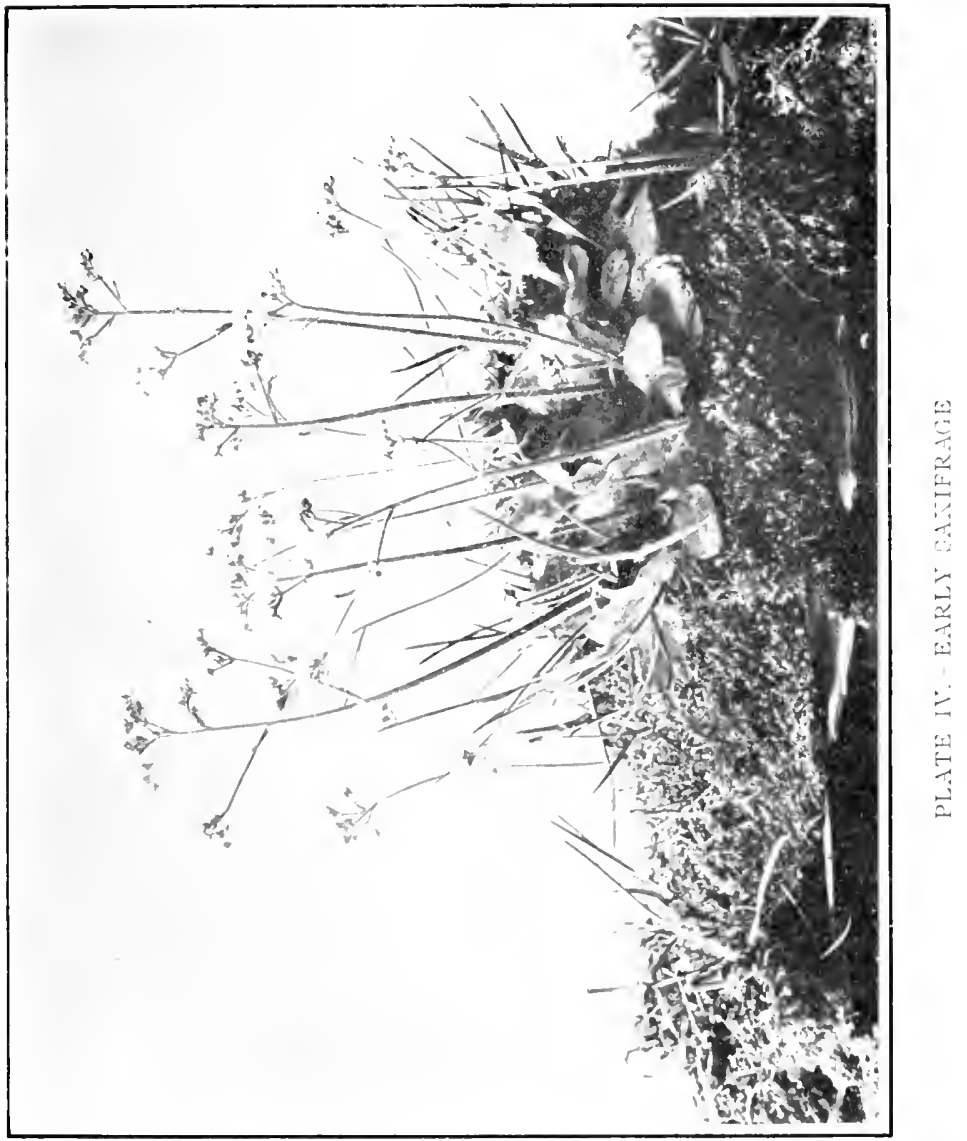




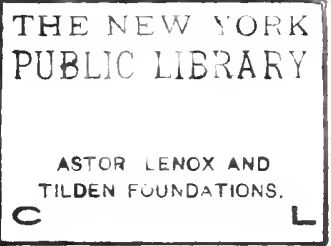


I shouldn't at all woncer if that was the very place where Tommy learned to say spring flowers were like fairies. When many of the little bells are open, the patch seems more like a playground for elves than for the feet of real people; and when I am with them there I can quite forgive them for being Lilies instead of Violets.

Even Grandmother could not tell me why the plant is named Violet, although she thought it was on account of its root being pointed and sharp that it was called Dog's-tooth Violet. The few blossoms that I carried home closed up tightly on the way, and although we tried to coax them open by putting their stems in hot water, it was of no use. I felt sorry that I did not leave them out under the great tree.

I have not told you yet that Tommy has a sister. She is only four years old, and her hair is straight and black. She looks like no other little girl I have ever seen, and not a bit like Tommy, whose hair is red. She wants to do just what Tommy does, although he is a boy, and so much older. Some days she will sing for us, and be very good; but at other times she stamps her little foot, and shakes her black hair, and runs and hides just when we want her most. Every one calls her Little Trudy.

Tommy is very proud of Little Trudy, and last Saturday he was going to take her to a boys' party in the village, only when it was time for her to 
be dressed, she couldn't be found. Tommy ran over to our house to see if she were there, and then he called, "Little Trudy, Little Trudy," so loud that many small birds on the lawn flew up in the air.

Grandmother and I started out with him to help find her. Even Peter knew something was wrong and ran ahead barking. Tommy said she couldn't walk as far as the woods, and she didn't like the stream because it made her feet wet. It might be that she had gone down in the meadow.

We turned that way and walked quickly, shouting, "Little Trudy." When we came to the barbed-wire fence Grandmother turned back, saying she would wait for us at Tommy's house. He and I slipped under the fence though, and came into the meadow next the woods. Here, we had not gone very far, when we both saw something white that looked like Little Trudy's dress. Tommy called again and we ran on. When we came closer we knew we had found her. She was half sitting down on the ground, picking Bluets.

"Little Trudy get bunch of pretty flowers to take to party," she said to Tommy. "Little Trudy pick very fast."

All over the meadow where she was sitting the ground was blue with tiny flowers. Tommy calls them Quaker Ladies, as well as Bluets; but Little Trudy, who doesn't yet know the names of flowers, 
says they are "get-me-nots." And I, who had never seen them before, thought also that they were Forget-me-nots. I see now they are not quite so deep a blue, and that their flowers have but four little leaves, while Forget-me-nots have five. Then the green leaves of Bluets are tiny and rounded, and snuggle so close to the ground that they look like one great bed of soft moss. The little plants are all sprightly and sweet, and perhaps for this reason they have been called Quaker Ladies. I think also it may be because quantities of them grow about Philadelphia, the Quaker City.

They must like the moist soil of the meadow, for so many hundreds and thousands of them grew together there that we could not always help stepping on them. Little Trudy had already picked her two hands full. She just took them up. in clumps, root and all. This displeased Tommy, but he lifted her up on his back and carried her most of the way home. She can't walk as fast as he and I, and Tommy didn't want to be late getting to the party. 


\section{CHAPTER IV}

\section{VIOLET MYSTERIES}

The way I first knew that Violets had come was by finding two little dead ones lying in the middle of a dusty road. I thought that some child had found them close by, and dropped them there. I climbed over the fence that separates the road from a large field, where usually the men plant corn. There I hunted for a long time, hoping every minute to see a Violet. But when the bell rang for me to go in to luncheon, my hands were still empty.

Grandmother asked me what I had been doing so long in the corn-field, and why I looked so disappointed. I told her all about my search, and showed her the two dead Violets I had found in the road.

"It may be," she said, "you have not looked in the right places for Violets. Later we will go out together, although not in the corn-field."

Grandmother loves wild Violets quite as much as I do. She says they make her think of her own childhood, and the joy she had when they returned each spring, and the turf grew soft and green. Tommy didn't go with us that day. Grandmother knows even better than he where Violets 
are to be found here, for they still grow in the very same places they did when she was a young girl.

After we had started Grandmother said: "It's likely we shall find several kinds of Violets today. They are not all purple with round, heartshaped leaves, as my little city girl supposes. There are besides White Violets, Yellow Violets, and purple ones with leaves queerly cut all about their edges. They all begin to open when Windflowers and Dog's-tooth Violets unfold, and as you have already found these, we cannot be too early to catch the Violets."

I said I should be happy if I could only find a purple one. White, or Yellow Violets were strange to me. First we walked along by the side of the stream where the grass grows tall. All the way I was looking for Violets. Suddenly I spied a little white one. It was almost under my foot. It was such a wee thing that I thought at first it could not be a Violet at all, yet its leaves were the same round, heart shape as those of the Purple Violet. Fine, brown lines ran through the blossom's white leaves, and it had a sweet scent, almost as tiny as itself.

"I used to call it the little Sweet White Violet," Grandmother said. "I think it has the sweetest scent of them all."

She started to walk on, but I stayed with the tiny Violets until I had to run to catch up with 
her. Then she called to me, and asked: "What color is the ground here, child?"

I was so excited that I called out "green," although it really was purple with Violets.

"Here are our city friends," said Grandmother, "long-stemmed Purple Violets, with rounded, heart-shaped leaves. They are the socalled Common Blue Violets, although you and I think they are purple." Here, in the high grass, many of them grew very tall, for they had to lift their buds up high enough for the sunshine to kiss them open. We each picked a bunch of these Violets. It could do them no harm, Grandmother said, because, like Pansies in the garden, the more they were picked the better they would bloom.

All through the grass we saw small, white flowers, with three, pretty, pointed leaflets which grew on slender stems. The blossoms, I noticed, had five petals, as I have learned to call flower leaves, and in shape they reminded me of a beautiful Wild Rose. Only they were not nearly so large.

"Do not pick them," Grandmother said. "They fade very quickly, while if left here each little blossom will turn into a wild strawberry."

"Then I can pick and eat them," I cried.

Before going on to the woods we went into the swampy field, and just after we left the wet place, where we can only keep our feet dry by stepping on big tufts of grass, Grandmother stooped down 


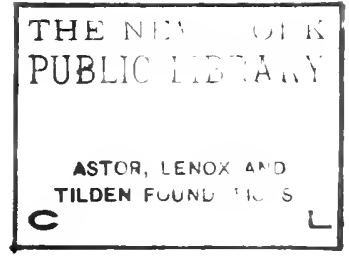


and said: "Here is our other White Violet; out bright and early."

Its blossoms were almost as large as those of the Purple or Common Blue Violet, and its leaves were rounded and heart-shaped. They grew from the sides of its stems. Any one would have known it was a Violet. I thought it a little strange seeing it so white, although its upper petals were tinted a little with purple. It is called Canada Violet, and surely it is much larger than the first little white one we had found. Grandmother said that it grew taller than most wild Violets.

In the woods we found two other kinds of Violets. One was tall and its deep purple face was very much like the Purple or Common Blue Violet; only its leaves, instead of being rounded, were jagged all about the edges. They looked as though they had been cut with scissors. Grandmother thought it was properly called Early Blue Violet, and that I should find it most often in the woods.

We did not see the Violet with leaves something the shape of a bird's foot, called Bird'sfoot Violet. It grows in more sandy places than our woods, and although I have searched again since then I have never found it yet, nor been quite sure I saw the little marks of bird's feet the Violet was named after. Even when I do find the Bird'sfoot Violet Grandmother says I must not pick it, as it is the one of the family that is growing rarer every year. 
After finding the Early Blue Violet, $I$ held in my hand four different kinds of these flowers. Then Grandmother reminded me there was still the yellow one which should be in bloom. She found it first. The pale yellow blossom was small and looked, with its fine brown lines, something like the Sweet White Violet. It had no fragrance. One thing about it that I could not help noticing was that its leaves grew out from the sides of the tall stem which held the flowers. They did not come up straight from the ground as did those of all the others we had found except the Canada Violet. These leaves, besides, were covered with a thick down, and I wondered if the plant was chilly and needed something to keep it warm, as the Hepaticas need their fuzz. Its name is Downy Yellow Violet.

It seemed strange to me that all these Violets should look enough alike for any child to know they were Violets, and still be so different. Yet Grandmother says there are many more kinds of them, and that I must be sharp-eyed to learn the names of all those even that grow about our home. In the book that I am soon to have for pressing flowers, I shall put in one of each sort that I find. Perhaps I will do this on rainy days and holidays, when Tommy pastes stamps in his album.

While Grandmother and I looked at the Downy Yellow Violet, I thought I should like to dig one up from the ground and plant it at home. So I 


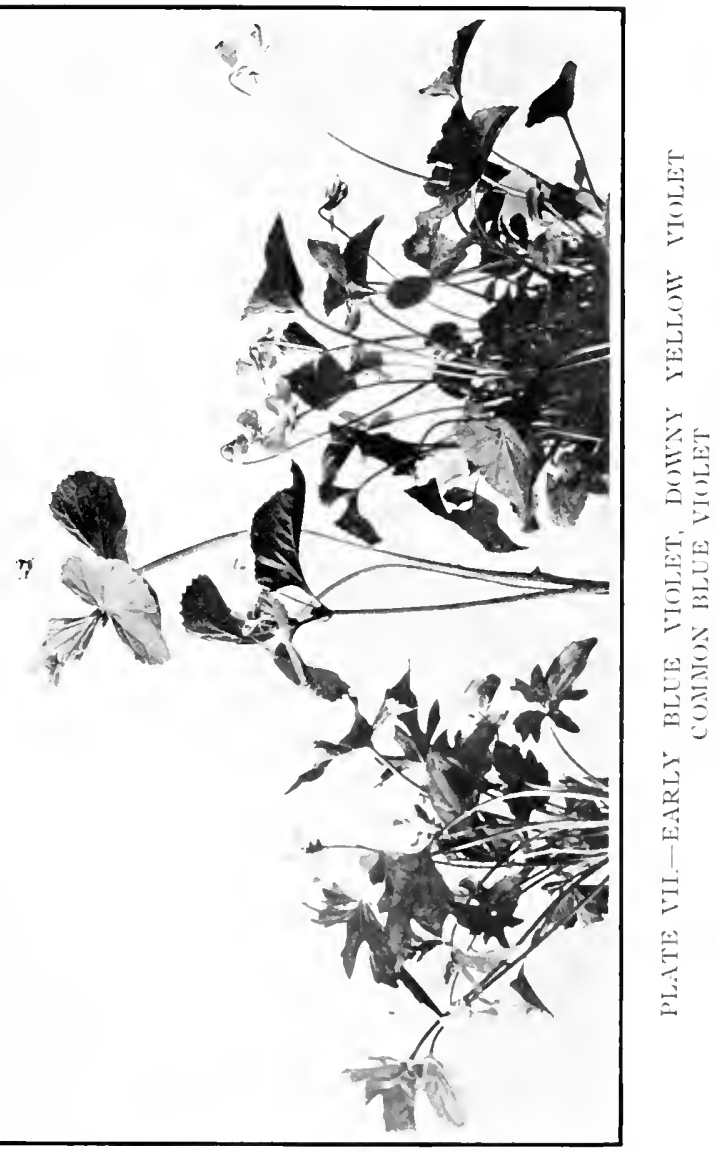




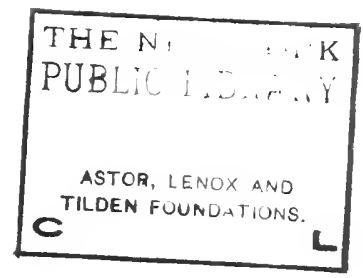


found a sharp stone and dug down in a circle around its roots. I was careful not to hurt it, and when I lifted it Grandmother quickly wrapped its roots and earth in some dried leaves. It was easy then to carry it home, and we planted it in a little fig basket, the same one that we had used in March for making a bird's nest basket, and put it on the window-seat, where it is shady, and it can have cool, fresh air like that in the wood.

When Tommy came to see us again he was surprised to hear many of the things Grandmother had to tell us about Violets. He didn't know for one thing that the purple ones were favorite flowers of Napoleon.

Just why Grandmother thinks them so much more modest than other flowers, and why the poets have written about their being modest, neither Tommy nor I could understand. I said I loved the Violet best, but that I thought the white Hepatica had a more modest look than any Violet. Tommy thought the Yellow Violet looked downright pert. He asked Grandmother if Napoleon were a modest man, and if he loved modest people. When she answered, "No, oh dear, no," it only made things more confusing.

But she said that we should love flowers for their own sake, and have our own impressions about them, no matter what other people thought or wrote about them.

When I went to bed that night, I felt that I 


\section{VIOLET MYSTERIES}

had learned a great deal about Violets. It all seemed very mysterious to me then, and with the white and yellow ones I still felt strange. In the morning, I thought, I will run out and pay them another visit. 


\section{CHAPTER V}

\section{THE SPIRIT OF SECRET VALLEY.}

Although Tommy calls the places where he knows certain wild flowers grow "bunks," he talks sometimes about Secret Valley. It is far away from any house and dark enough to scare most girls, even when the sun shines, and so full of water that no one could go there and come out again without getting pretty wet. One day he said:

"The trouble with Secret Valley is that you never know just where your foot is going when you put it down. You think to set it on a little hill of grass, but it often slips off, and you go knee-deep in the water. Peter would rather do anything than go to Secret Valley. The water there is not the kind he likes for a good swim. It is covered with pale green stuff, like seaweed, and never looks bright and shiny."

It is in the spring that Tommy goes to Secret Valley. Then he can see better where he is stepping than when tall weeds cover up the slippery places. The valley always looks cheerful in the spring because then the Spice Bush is blooming, and thousands of its tiny, yellow flowers give the place a real sunshiny look.

Like the Red Maple it blooms in early April, 
and because it is a bush instead of a tall tree, it is easy to get up close to it and look at its pretty, fluffy flowers. They are quite a pale yellow, and grow together in little bunches all along the sides of the bare twigs. As yet there is not a single leaf on the bushes. They burst out later.

Grandmother thinks that when the Red Maple and Spice Bush are blooming the woods are more beautiful than at any other time. She told me also that when we had our great War of the Revolution, many housewives used the dried leaves and berries of Spice Bushes in their cakes, instead of spices. It was not easy then for people to buy everything they wanted.

But because the Spice Bush grows in our woods and all along a little path on the way to the village, I know it is not especially to see it that Tommy goes to Secret Valley.

The last time he came back from there he had a very queer look, and I felt sure that something had happened to him. He said he had gone to the valley for a flower called Marsh Marigold; but he came home without the least little sprig of it, and this seemed strange as he wanted to show it to me. I asked him what Marsh Marigold looked like, and he said: "A big Buttercup, only it is wide awake while the Buttercup is still asleep."

Its leaves are very large and shiny, and it grows in swampy places, where it is hard to reach. Often Tommy finds it near Skunk Cabbage. 


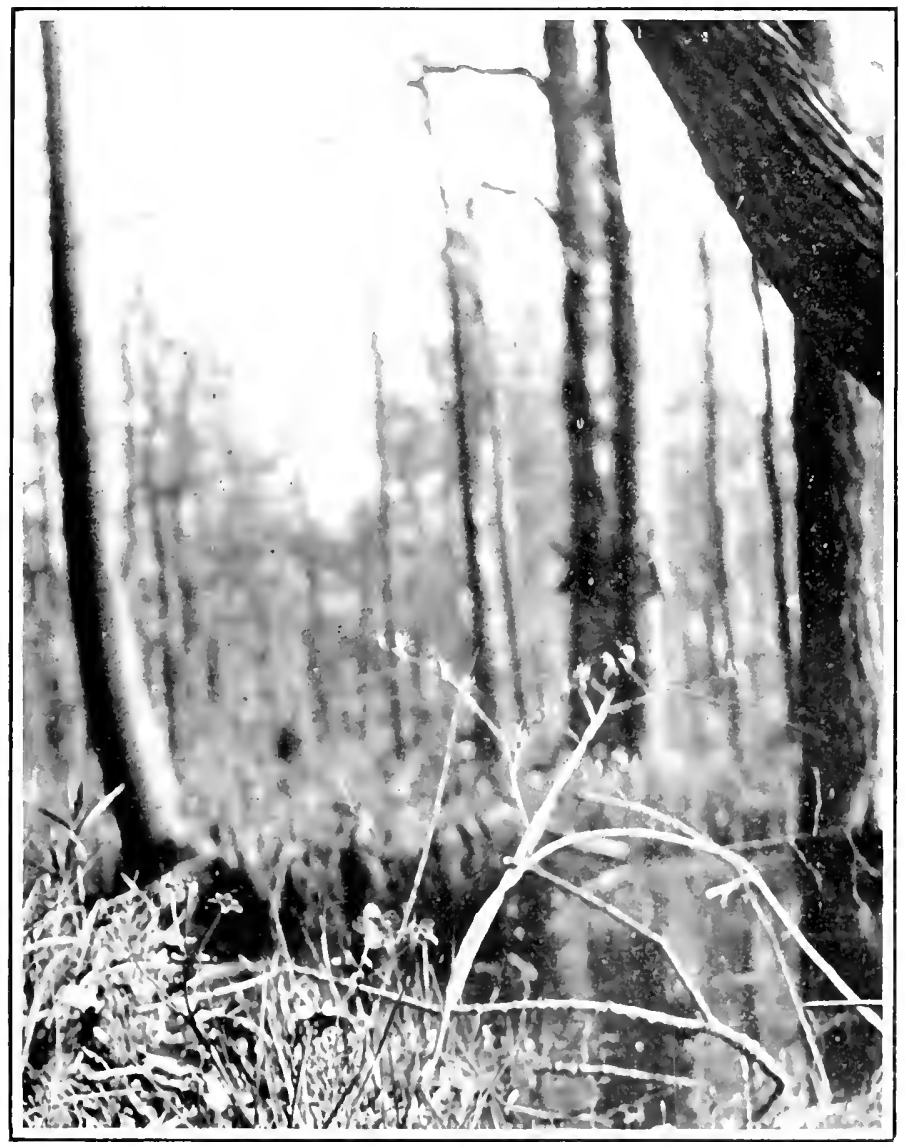

PIATE VII SIETRLT V.M.J.J 


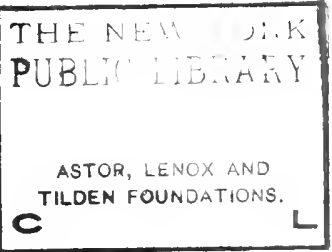


Country peopie scrape its young shoots and boil them to eat, as the cook does asparagus. They also call it Cowslip, which is not the right name for it, because that belongs to a flower which grows in England. Shakespeare's name for it was Mary-bud, the prettiest one of all.

I feel sorry not to have seen Marsh Marigold, altiough I think I shall know it when I do, from what Tommy has said.

The curious way he has acted since coming back from Secret Valley is still puzzling. $\mathrm{He}$ surely saw something there besides the Spice Bush and Marsh Marigold. He has been very solemn and whenever he speaks it is to say that girls are "great muffs." Once he said they were very bold. I think on Sunday, when there isn't much to do, that he may tell us what has changed him so much. I know already that Philip Todd told him there was a nest of white crows in Secret Valley.

Philip sits in the next pew to Grandmother and me at church, and he is in Tommy's class at school. They are great friends. But Philip does not care much about wild flowers. He likes animals better, and has a great many pigeons and pets. All his books are about animals. Sometimes he and Tommy have long arguments together. Now Tommy never tells anything about wild flowers that is not really true. He never makes them out one bit more wonderful than they are-he doesn't have to. But Philip tells some stories about ani- 


\section{2}

\section{THE SPIRIT OF SECRET VALLEY}

mals that seem very hard to believe. I think what he said about white crows has had something to do with Tommy's strange look since he came back from the valley.

On Sunday, after church, I asked him if that was not so, and then it all came out. $\mathrm{He}$ told Grandmother and me the whole story as we were walking home through the garden.

He did go up to Secret Valley to find out if Philip's story was true, and looked into every bird's nest he saw that was built high enough for a crow's. But they were all as black as ink. Then he sat for a long time watching to see if any white crows were flying about, and again every one he saw was black. It was beginning to grow cool, and the sun had almost given up peering like tiny gold spots through the trees when Tommy looked up and saw, just in the middle of the wet ground, and standing on the trunk of a dead tree, not a white crow, but a girl.

She held her head up high, and reminded Tommy of the girls he had read about. Her hair was straight, and her hands hung down by her sides. She didn't appear to notice that a plant called Baneberry stood up beside her.

Tommy thought this very queer, for the plant had bloomed earlier than those in our woods. Perhaps it was better suited with the rich soil of Secret Valley. Its bunch of soft white flowers, which appear to be all fluff, for their little petals 


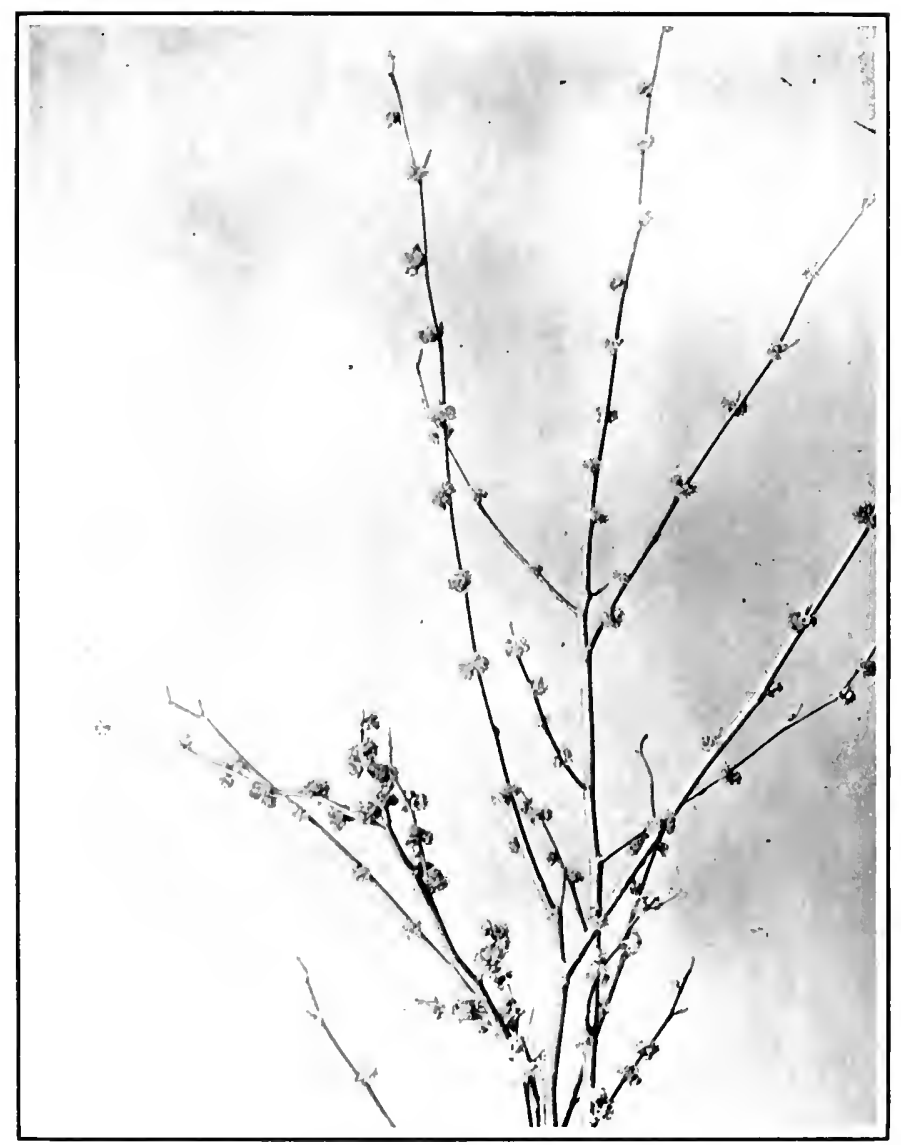

PLATE IX. THE SPIV BUSH 


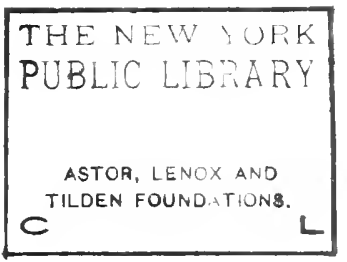


are small and short, had already fallen, and in their places were left only little stems where round berries were forming. But neither they nor the Baneberries' beautiful pointed leaflets made this strange girl look at them, and she didn't mind a bit that a darning needle was close by her hand.

She never spoke to Tommy, although she must have seen him sitting there watching for white crows; and she looked so much like a statue on the tree's stump that he didn't speak to her. After awhile he crept away very softly, and forgot all about bringing home a bit of Marsh Marigold.

Since then he has been wondering who this girl could be. He had never seen her before, although he knows every one who lives near here and in the village. He says she looked as though she never intended to leave that stump, or Secret Valley.

He has told Philip Todd nothing about all this because he doesn't want him to know he ever believed there were white crows in the valley. Besides, he says he will go again in a few days to see if the girl is still standing on the old tree's stump.

Grandmother called out to him: "Keep well awake, Tommy, if you do; for surely you were half asleep and dreamed that you saw the girl spirit of Secret Valley."

Then Tommy declared that he was wide awake every minute, and that he had seen a real girl with straight hair. 


\section{CHAPTER VI}

WHAT SALLIE FOUND OUT ABOUT BLOODROOTS

The bullfrog is not croaking so much now as when we first came to live in the country, but his appetite for crickets is as keen as ever. His life is quite apart from that of the little woodland flowers, and lately I have not seen so much of him. Another reason for this is because it has rained for two whole days. There has been no sunshine nor bright blue sky; even the soft, white clouds have been away. Things have just looked dull and gray all over.

While it has been raining so hard, I have thought of the flowers in the woods-the Violets, the Wind-flowers, Rue-anemones, and Dog's-tooth Violets-and wondered if they were drowning. Hepaticas and Early Saxifrage and Dutchman's Breeches were already gone before the rain came. Even now that the blue has come back to the sky, and the sun is peeping out a little, I cannot run out to see if the flowers are still there. The ground is very wet, and besides we are expecting Sallie.

Sallie's full name is Sarah Hubbard. Grandmother chose this time for her to visit us because she wanted her to see the country looking so beautiful. She lives in the city most of the year, and I 


\section{ABOUT BLOODROOTS}

think she knows very little about the country. She is only a year older than I, but much taller. She loves dogs, and even cats, and she has been across the ocean six times.

When she comes to-day it will be too late to go out in the woods and much too wet; but in the morning I shall show her some of Tommy's bunks. I feel sure she doesn't know that wild flowers come up every year in the same places, and that people who live in the country learn to know just where to find them. Then there is Tommy's dried collection of plants for her to see, and Philip Todd's pets and ever so many other things.

Sallie has come. She has grown taller since I saw her last, and her hair is braided instead of hanging down her back. She says that she loves wild flowers, though she seldom sees them, because almost every summer she goes to Europe, and to places where there are cathedrals and picture galleries, but no flowers. For a minute I felt as if I wanted to go and see such places too; but when I remembered all the little flowers that were coming out, I thought it would be hard to leave them.

Tommy came to-day while Grandmother was having tea in the library, and the first words he said were: "There's another flower out for you to show Sallie."

Grandmother asked him to tell us all about it. 
"Its name is Bloodroot," he said, " and it is very white, as white as snow. It opens in the shape of a cup, just fit for butterflies to sip from, and its center of little fluffy things is the color of gold. The most wonderful thing about Bloodroot is the good care its leaves take of the young flowers. They stand up straight from the ground and stay wrapped around the buds to keep them warm until they can open without getting frost-nipped. Then another curious thing about Bloodroot is that right under the flowers there are two tiny leaves-botanists call them floral leaves -which look brown and crisp like tissue paper. Very few grown-up people have ever seen them," he went on to say, "because they fall off before the flowers are fully open."

Tommy spoke very wisely, yet Sallie said: "Tissue-paper leaves must look queer; have you seen them, Tommy?"

Tommy answered: "No, I have only read about them."

After we had had luncheon the next day, and the wind had blown things dry again, we all went out to see Bloodroot on the high ridge in the woods. It looked to me even more beautiful than Tommy had said, and both Sallie and I could see quite plainly how some of the large leaves were still taking care of the young flowers. But under the flowers we found no leaves that looked like tissue paper. All the stems we saw were bare 


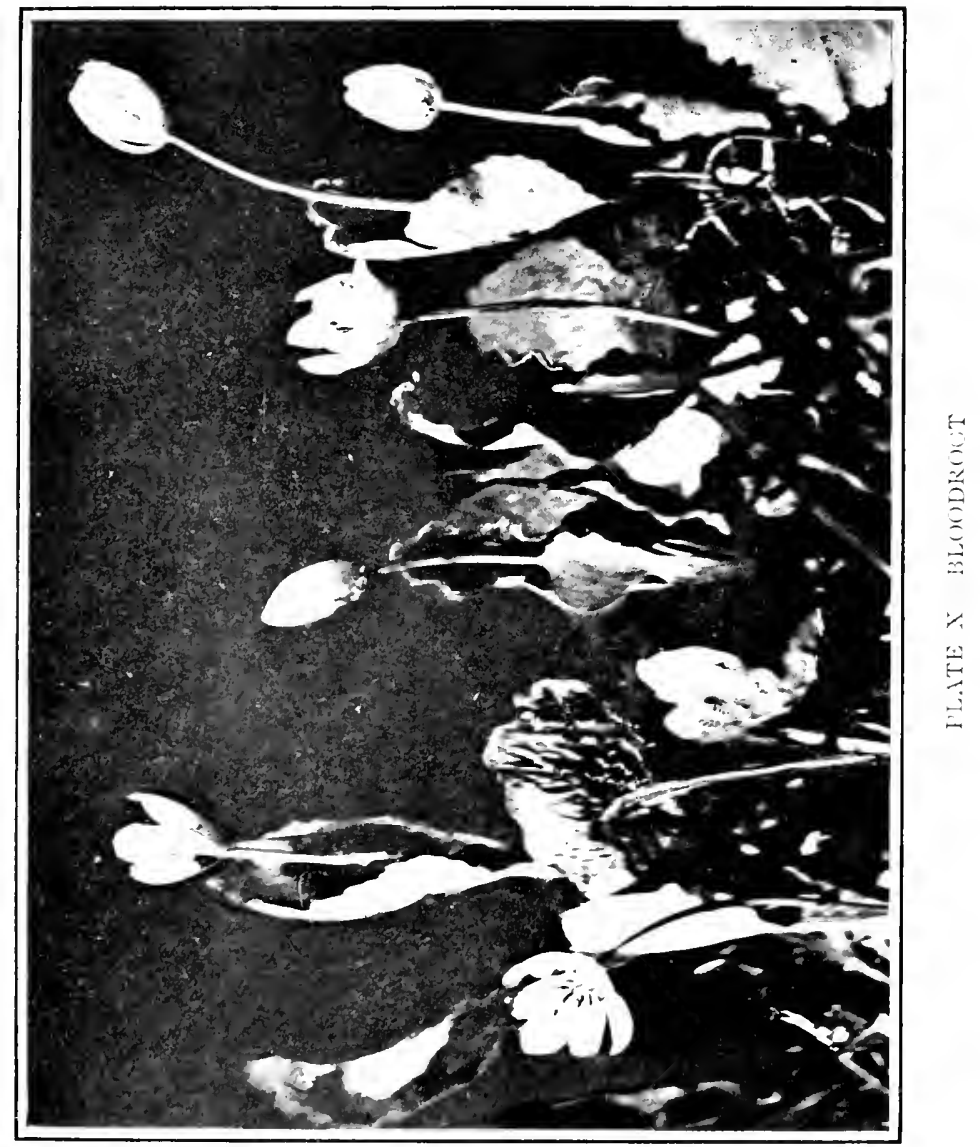




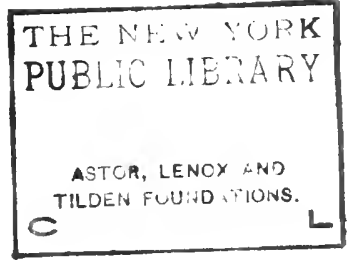


and smooth, and at their tops sat the pure white Howers.

"Perhaps we are not out early enough for the little brown leaves," Tommy said. "Daybreak might be the time to catch them."

Sallie was the most disappointed of us all at not finding them, and went on looking under each flower long after Tommy and I had given them up. I thought perhaps they might be just as hard to find as Philip's nest of white crows.

Afterward, when we were gathering Violets to take home to Grandmother we forgot about Bloodroot and the tissue-paper leaves.

In the morning, as soon as I was dressed, I ran downstairs to find Sallie, for she was not in her room; neither was she in the dining-room nor on the veranda. Grandmother was beginning to wonder where she could possibly be when she came in. She had her hat on and in her hand were some Bloodroots.

"So you have been to the woods already?" Grandmother said. "My little girl here is never out so early."

Sallie was so delighted about something that she danced all around the table. Then when Grandmother said it was the country air that made her so lively, she put down the Bloodroots, and under one of them there were two little leaves looking just like tissue paper.

"Even at daybreak," Sallic said, "they are not 
easy to find. The birds awaked me chirping, and after that I could not help thinking how fine it would be to go out and search for those little leaves."

I knew that Sallie must have been up very, very early, as the birds are about as soon as dawn breaks, taking breakfast and singing in between times.

"When I was really up," Sallie said, "I made great haste to get out of the house. Everything here was so still. But it was cool out-of-doors, and once $I$ had a mind to run back and cuddle again into my soft, warm bed. Then the sun peeped out to cheer me and I ran on. The dew was hanging on the grasses like tiny soap-bubbles. I was not a fraid being out so early; but once I had a little scare.

"It was as I turned from the open field to go toward the Bloodroot ridge. I heard such a funny, bounding noise, and just as I was thinking which way to run, a rabbit gave a leap behind me and sat quite still. His ears were lifted straight up, and he looked surprised to see me out so early. My heart beat very fast. Indeed I was about to ask him if he wasn't also frightened when he bounded away. It seemed silly to be so frightened at just meeting a rabbit, and afterward I laughed at his funny look. Then, in a few minutes, I was with the Bloodroots.

"They were all asleep. Even those which we 


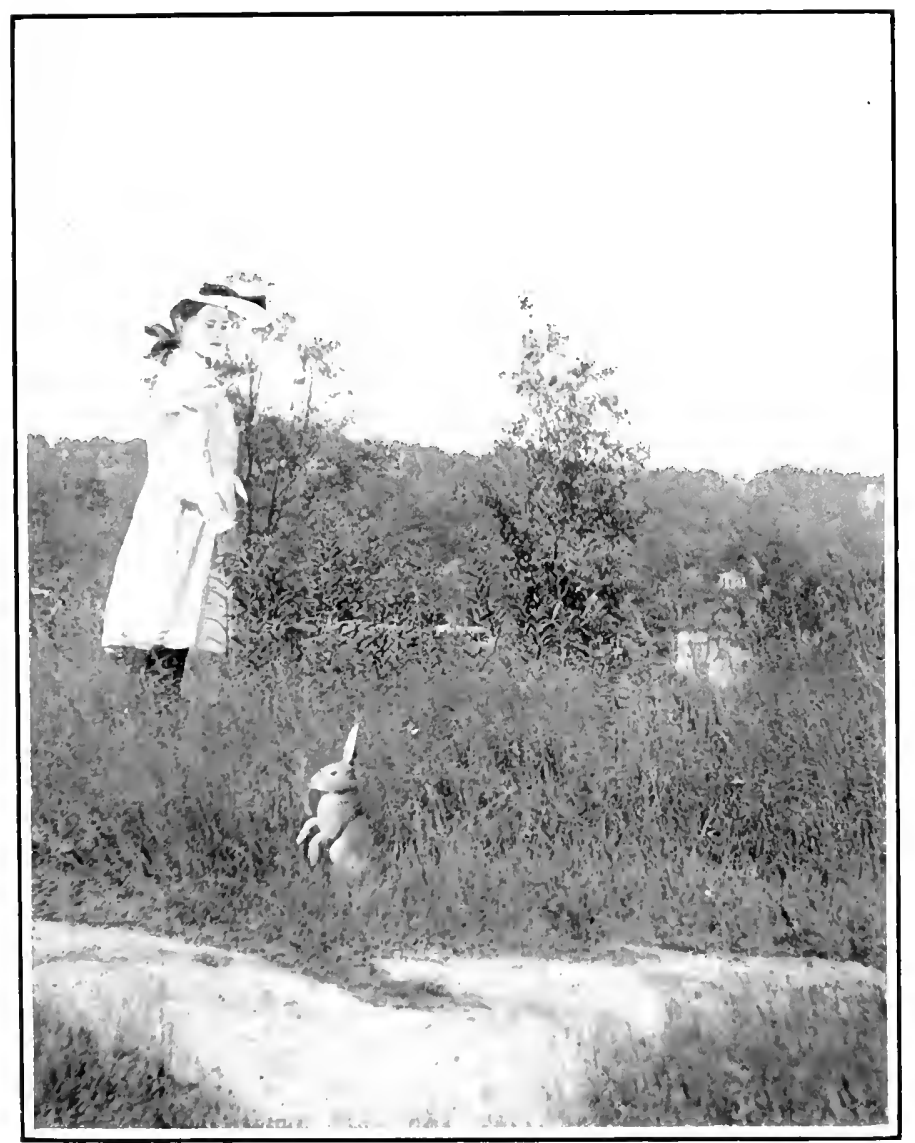

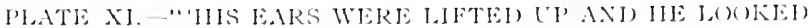
SL'RIRISED TO SEE NE'" 


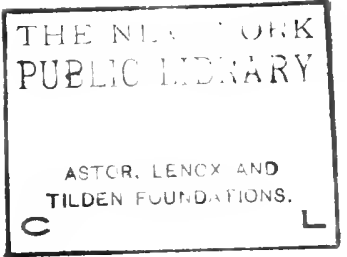


saw yesterday wide open were tightly closed, like buds. I had no idea when they might awake, so I began passing from one to another, looking under the closed heads to see if there were anything like two thin, brown leaves. After a while I wondered if Tommy had not made a mistake.

"It was lonely in the wood with only the Bloodroots about me, and they fast asleep. Soon it seemed to me as if they were awakening. The sunshine had begun to slant in upon them. Indeed they were opening. One was wide awake. A green leaf that I watched appeared still a little uncertain about opening very far to let the bud come out, so I slipped my finger down through its top, and helped it along a little. The bud on the straight stalk inside was snug and warm. And something else I saw: the two mysterious little leaves. They clasped the white bud like a brown paper wrapping. Tommy was quite right. I broke off the stalks close to the ground, and here they are, just as I found them, the green leaf wrapped around the bud, with its thin, brown leaves underneath. My hands, after picking them, were covered with a red and yellow stain."

I took the Bloodroots from Sallie and put them in a cool spot on the window-sill.

"It seems as if I had been gone a long time from the house," she said, "I am so hungry."

"You will both be botanists when you grow up," Grandmother said, as she laughed. " It will 
be a good beginning to know about those little floral leaves. When I was a child I learned that Bloodroot had been a very good friend to the Indians. It was with its sap that they painted their faces and dyed their feathers and straws for their baskets. Sometimes it is called Indian Paint, or Red Puccoon."

I was just a little sorry not to have heard this story before Francis went home. 


\section{CHAPTER VII}

\section{ANSWERS TO FRANCIS'S LETTER}

The first letter that Grandmother received from Francis was nearly all about flowers, and he asked so many questions that she thought she could not answer them all at one writing. Tommy and I decided to help her a little.

Francis had spent almost every minute since his return to New England in the woods. He had found Butterflies' Banners, as he still called Dutchman's Breeches, and was sorry that the time had come for them to fade. He wrote: "I wonder if you all love Spring Beauty. It fairly covers the ground here, and its delicate white blossom is very like the Wind-flower, only running through it are fine pink lines. Its leaves look very much like grass, that is, they would if thcy stood up straighter, and it is by them and the pink veins in the flower that any one can tell it from Wind-flower, or Rue-anemone. In our woods it spreads out like mats over the ground. But I have noticed that it is quite a fair-wcather lover, for when it is cloudy, or rain is falling, the pretty blossoms close tightly. I think this is because too much wet is not good for its health.

"Please write me," he went on, "if it grows 


\section{ANSWERS TO FRANCIS'S LETTER}

in your woods about the stumps of old trees, and if you are not more fond of it than Butterflies' Banners."

Tommy told Grandmother he thought a good answer to send Francis about Spring Beauty would be that thousands and thousands of them grew through our woods, and about old treestumps, and even out in sunny spots, and that it lasted some time after Wind-flowers had faded. Then he wanted Grandmother to say that he didn't care for it nearly as much as for Butterflies' Banners, and that he really loved it most on account of its sleepiness. "You might add," he said to Grandmother, "that the Spring Beauty is always sleepy unless the sun touches it and coaxes it to keep awake. I've read that it turns its blossoms around to face the sun, only I don't believe that is true."

I thought Tommy's answer would do, because Spring Beauty had disappointed me by closing up its flowers when I had put a pretty little bouquet of them in a glass bowl.

Francis told us in his letter about a plant called Large-flowered Wake-robin. "It is one of the Trilliums," he wrote. Now this excited Tommy very much, for although he had read and knew about the same flower, he had never found it.

"It was when I was looking for Jack-in-thepulpit that I saw it," Francis wrote. "Its leaves are something like Jack's, only there is but one 


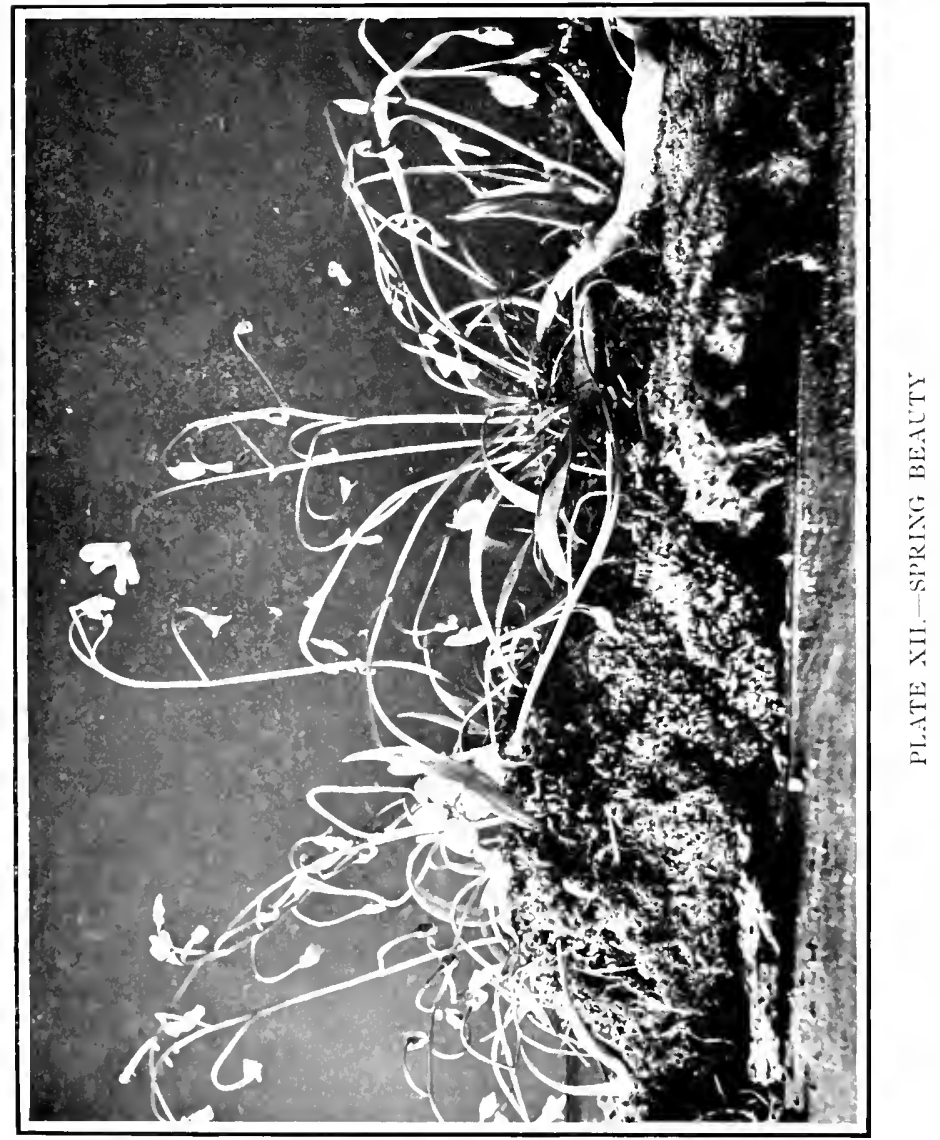




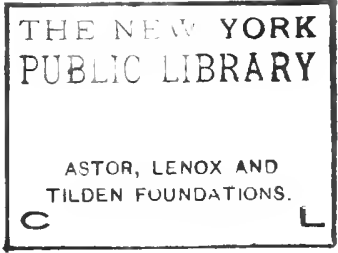


stalk to bear them, while the Preacher has two. The Wake-robin has just three pointed, large leaves, and they grow around the top of the stalk, underneath the flower. This is white, with also three pointed leaves, or petals, and it looks something like a fine lily that grows in mother's conservatory. There is only one place in our nearest woods where it grows, and there Spring Beauty is on one side of it, and a little distance the other way a stalk of Solomon's Seal is in bud."

Francis didn't understand why the plant was called Wake-robin, for he wrote he had never seen that bird in shooting distance of it.

Grandmother said this was from a pretty legend telling that as the Trilliums, or Wake-robins, blossomed early in the spring, they were the flowers chosen to wake the robins.

"But they don't open nearly as early as robins are awake," Tommy argued. "And if Trilliums live only in deep woods, I doubt that robins go near them at all. They like to hop around on lawns and build nests in orchards. They are almost as fond of the sun as Spring Beauty."

Tommy asked Grandmother to write that he should not give up trying to find Wake-robins somewhere near our home, and he wanted her also to tell Francis that two days ago he had seen three Scarlet Tanagers sitting on a fallen tree-trunk near the rock called Old Adam. He looked around by accident and there they were in a row, their wings 


\section{ANSWERS TO FRANCIS'S LETTER}

brighter than flames of fire. First one called out its note, and flew off, then another followed. No skyrocket on Fourth of July, Tommy said, was ever so beautiful as these birds, darting through the tree-tops. For a long time the third one sat alone on the tree-trunk. Tommy stayed where he was and did not make a sound. Then a shower of dead leaves fell through the air and the bird was up and off in the same direction as the others.

Grandmother wrote herself to Francis that she would offer a prize for the child finding the first Wake-robin. It was not to be picked. She must just be told where it grows, so that she might go and look at it. We all know now that Trilliums are rare flowers, and that we shall have to hunt hard to find them. Tommy thinks besides that they are most likely to grow farther away from our house than I can walk. "The rare wild flowers," his father told him, "don't like man, and as he draws nearer they move farther away, and hide in dense woods.

Tommy said: "It must be a terrible thing for a delicate flower to have a man, or even a boy come near it. Ten to one he means mischief. If he sees it and it's pretty, he's very apt to pick it, because he thinks that's what it's for; but if his head is filled with shooting birds, or something else he's likely to stamp it to death without seeing it at all. If flowers could talk they surely would have something to say about how they trembled 


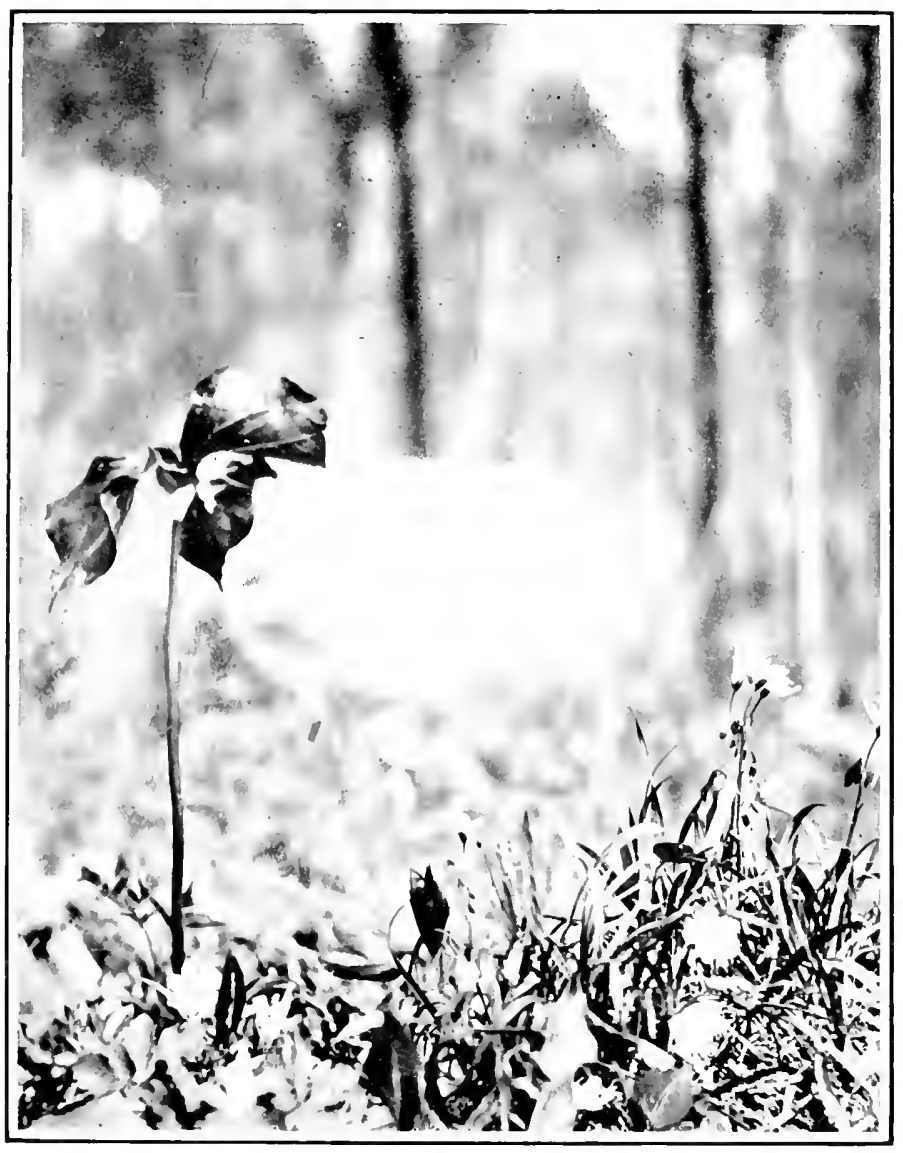

PLATE XII.-TIE LARGE-FLOUEREIS WAKE-ROHIN 


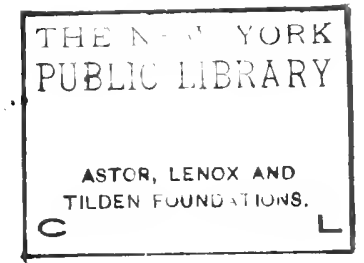


and turned pale, and how their hearts beat whenever they felt the earth about them stirred by footsteps.

"Even when they are picked they are carried off to see a world they know nothing about, and then are thrown away because they fade. It's very odd," Tommy went on, for he was in one of his talking moods, "that grown people sometimes say flowers have no feelings. Many flowers go to sleep, like the Spring Beauty, and awake just as regularly as I do. Others are so sensitive that they close their leaves at the slightest touch of my hand. It is a pity that they can never speak out boldly and let people know how much they feel. They can't even cry like babies, until they get just what they want."

"Am I to put all that in Francis's letter?" Grandmother asked. "It seems that a boy with so much feeling for flowers has small mercy for our postman's shoulders."

Tommy laughed and said perhaps he had better write a letter to Francis himself; but that he should not do it until after he had had a good tramp hunting for Wake-robins.

Philip Todd is quite sure he is going to get Grandmother's prize, and says any flower is easy enough to find; but I think it will either be Sallic or Tommy who first tells her where the Wakerobin grows. Tommy himself seems to think that Sallie will win the prize. I have noticed that 
46 ANSWERS TO FRANCIS'S LETTER

since she went out at daybreak and found the Bloodroot's queer little leaves, he has quite ceased to think of her as a city girl who knows nothing about wild flowers. 


\section{CHAPTER VIII}

\section{JACK-IN-THE-PULPIT AND HIS FRIENDS}

Ever since Violets have bloomed, Jack-in-thepulpit has been in the woods. I have not mentioned this before because there were so many other things to say; and also because most boys and girls already know Jack quite well.

It would be a hard matter, I think, for any one to miss seeing the Preacher, as Jack-in-the-pulpit is also called. First of all two tall, large leaves come up from the ground and they are both divided into three pointed leaflets. They stand up straight above the flower's head, quite as though it were their intention to make sure it should have enough shade. For even in the thick woods where the Preacher loves to grow there slips in sometimes warm, bright sunlight, which doesn't suit Jack. But with the two leaves flaring overhead, the flower is just as well shaded as though it had a parasol.

The flower part, that every one calls the pulpit, grows on a little stalk of its own which is tucked in between the leaves. It looks like a funny leaf, closed together at the bottom, and ending in a long point which hangs down. Grandmother says it is something like the hood over an old-fashioned 
pulpit; a kind that I have never seen. This pulpit is green or else green streaked with purple.

Just inside it there is a little straight piece, and this is Jack, or the Preacher that stands always in his pulpit. Now what is very curious is that neither the pulpit nor the Preacher are true flowers, although each Jack-in-the-pulpit bears very many. These are tiny little things, growing around the bottom of the stick that every one calls the Preacher. Indeed these florets grow in the same way, and are just as little seen as those of Skunk Cabbage.

Grandmother says they both belong to the same family. They are first cousins, at least, and in many things their ways are alike. I believe they are even more alike than Francis and I; although Skunk Cabbage is coarse and has a bad odor, while Jack-in-the-pulpit is very refined and has no odor at all, except one that is like the green woods.

I think that Jack-in-the-pulpit has more friends than any other plant. Tommy speaks of it as though it were a real friend.

He says, "There's a fine fellow," when he sees one that is taller than others; and he calls this plant "he," instead of it. This must be on account of its name, for I never heard him speak of Skunk Cabbage as "he," nor of a Violet, nor any other flower.

"Jack-in-the-pulpit is very much like us," I 


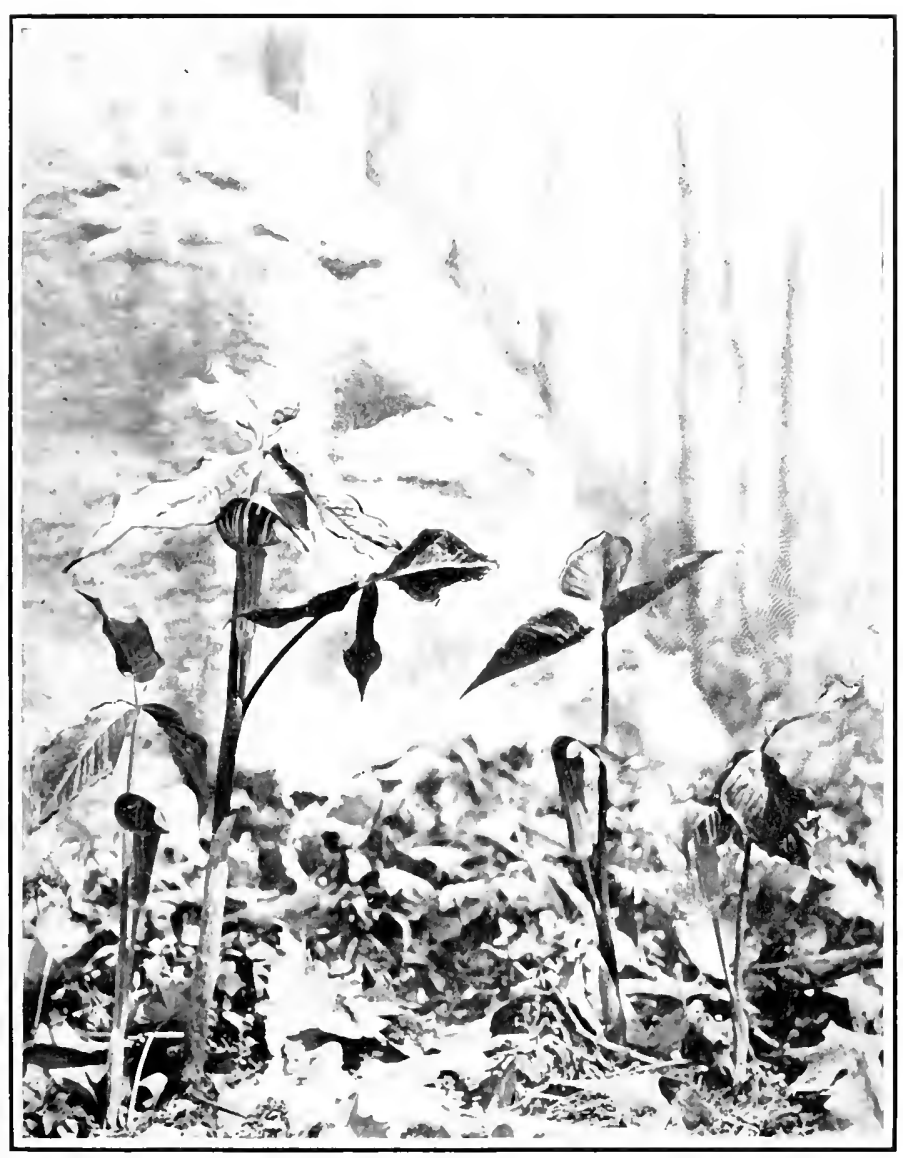

PLATE XIY-JACKS IN THE SPRING WODS 


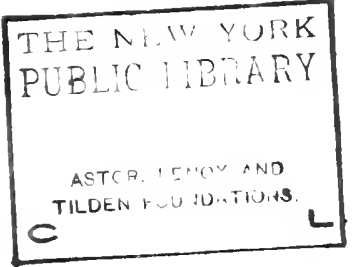


heard him telling Philip Todd. Philip said, with one of his queer laughs, "He hasn't much Christian charity."

After this they talked a long time about the Preacher, and I learned that they both think it punishes little insects that crawl into the pulpit for the sake of sipping the tiny florets' nectar. It is easy enough for them to get down into the pulpit, but when they want to come out they find that its inner sides are too slippery for them to walk over. Then above where the florets cluster around the little piece called Jack, it grows larger, forming a ledge, which makes it quite impossible for small insects to get out by using their wings. Just why the Preacher wishes to keep them down in the pulpit until they die neither Tommy nor Philip knew.

But an old gentleman who comes to see Grandmother sometimes, and who is a botanist, has told us since then that it is because the plant really wants them for nourishment. It uses them after they are quite dead, as we do food.

At the Botanical Garden at Bronx Park, I saw a plant which did this very same thing, only in a different way. It was called Venus's Fly-trap, and its leaves were exactly like little traps with hinges in the middle. All around their edges were sharp bristles. I saw these leaves catching the flies that visitors to the garden fed them; and the people said the plant was known 
the world over because it had such a wonderful appetite for flies.

Sallie has seen Venus's Fly-trap at Kew Gardens, near London. She was there last year in April, so she saw also its white blossoms. These grow on stems much higher than the leaves and have just five white petals. At Kew the plants were shown as very great curiosities, and so many people went to see them that a guard stood close by, asking every one not to give them anything to eat.

"They have been overfed to-day," he said, "and their traps are not working."

In America, Venus's Fly-trap grows in very few places. One of these is near Wilmington, in North Carolina. But Tommy says it has a relative that grows in bogs near here, called Sundew.

'Another thing that Sallie learned in England is that there Jacks-in-the-pulpit are called Lords and Ladies. The ones most green are the Ladies, and the ones with purple stripes are Lords.

Tommy said to Grandmother: "No matter where you are in the woods the Preacher never lets you forget him. I'm just as fond of him when his pulpit has fallen to pieces and he has turned into a beautiful cluster of red berries, as I am when he first comes, and has about him Windflowers and Rue-anemones, Bloodroots, Dog'stooth Violets and a whole gay company."

All through our woods I have noticed other 
leaves than Jack's that grow tall, and are rounded, and have a soft feeling like velvet. But I cannot find their flowers. I have turned them over and over, and peeped under them, and still there is not a bud in sight. It isn't as though I had only seen one or two of these leaves. I might have forgotten them then. But I meet them very often, and quite a number of them grow together. There are places in the woods where they snuggle by each other very closely. I thought it was not yet time for them to bloom, so when Philip Todd told me they already had their flowers, I kept very still, thinking he was playing some joke.

"I'll show you those flowers," he said, "and when I do, you'll say, no wonder you didn't find them yourself."

We went to a patch of leaves, and Philip got down on his knees and began poking in the soil with his finger. I thought every minute he would let his joke out, and so I was surprised when he did lift up from the earth a real flower. It was a curious little brown thing, shaped something like a bell, and covered with earth. It seemed to want to cuddle down, and fairly get inside the earth. I said: "So you are a little flower that doesn't want to lift up your pretty head."

Philip said: "It wants to burrow into the earth like a woodchuck. Its name is Wild Ginger, and the reason it is called that is because 
the root has a taste like ginger. There's a lot of it about here, and every year it plans for more to come. That little hiding flower forms a capsule filled with many round seeds. Then when it bursts, it does so very quickly and the seeds fly out in all directions. You see, it doesn't run the risk of being picked that other flowers do by standing up and letting every one see that they are pretty." Philip had talked so much about Wild Ginger that he said he felt hungry. We went back to the house, and it was just the time that Grandmother was taking her afternoon tea. The cook brought her in some cake besides and we had jam on our bread-and-butter. 


\section{CHAPTER IX,}

\section{WHEN DOGWOOD BLOOMS}

WheN May came there were still many flowers in the woods that had begun to bloom in April; and many others were unfolding that were strangers to me, and whose names I did not know. The little early spring blossoms that I had seen and cared for like Hepaticas, Wind-flowers, Dutchman's Breeches, Saxifrage and Dog's-tooth Violet were all gone, although Violets stayed, and so many Spring Beauties were awake in the woods that often I nearly stepped on them. Tommy knew that Wake-robins still bloomed; but no girl or boy had yet won Grandmother's prize by finding one. The woods in May quite lost their bare look; most of the dried leaves had blown away, and tall weeds and grasses sprung up everywhere. I thought it more difficult to find wild flowers than when the ground was bare.

But there is one flower now in the woods which every one must see. It is Dogwood, a large white blossom that comes on shrubs or small trees. Now that it is in bloom the woods look gayer than if they were going to a party. These blossoms can be seen from a long way off, and no one could help thinking that they made the country beautiful, even if he didn't love flowers.

I used to think that Dogwood blossoms had four 
beautiful white leaves, each with a little pink notch in the middle of its edge. This I know now to be a mistake, and that the leaves which nearly all children think are white flowers are just envelopes keeping the true Dogwood flowers from suffering any harm, just as a real envelope keeps a letter tidy. These true flowers are tiny, little, green things, and we see them all packed together in the center of the beautiful white leaves. It isn't likely that many would know about them, and certainly no one would call them beautiful, if the white envelopes didn't wave so gayly, calling to hundreds of people to look their way.

Insects see them as well as people, and when they fly up to make them a visit, they soon get to know the little green flowers which otherwise they might never see.

It seems very strange to me that flowers could never live happily and bloom if they were not visited by insects. They are their messenger boys, and carry the golden dust which helps them to form seeds. They take it from one flower to another, and if it touches just the right spot, seeds soon begin to form and to grow. Sometimes the insects don't even know they are carrying the golden dust. It is light, like powder, and clings to their legs and wings. At the next flower's house they visit, they perhaps spill a little of it, and this, of course, is just what the flowers want.

So, it is really to catch the insects' eyes that 
Mother Nature has given the plain little Dogwood blossoms the beautiful white floral envelopes.

All this I found out from Grandmother's gardener, Herr Wilhelm Fritz. The rest of his name is too long and hard for me to write. He was talking about Dogwood the day the men were planting corn in the field.

"Ven it plooms," he said, " der time has come ter drop in der corn kernels. Der tree is pretty veather vise."

Since then I have heard Tommy talk about Dogwood. He thinks people, and especially girls, look so long and so much at the white floral envelope that they never notice all the other things that are beautiful about the tree.

"There are its twigs," he said; " almost before the winter is past they show glimmers of bright colors; and when the ground is bare again and Jack Frost is here, its red berries have a look as gay as holly."

Sallie is enchanted with Dogwood. She loves to get close up to the trees, and when the boughs hang low enough, she takes them in her arms, and looks and looks at the flowers. I can tell by her face that she is thinking very hard about something. Sallie writes wonderful compositions at school, so perhaps she will write one about Dogwood, telling how it looks when it is just budding; how gay it makes the woods in May, and then how bright its berries are in the autumn. 
Francis has already sent Grandmother a little sketch that he made of Dogwood. He also wrote a note to Tommy and said it was most "paintable." In his letter he wrote besides that he had quite decided to be an artist.

Philip Todd has grown to love Dogwood, just as much as he does his pets. He went out yesterday to hunt for wild flowers with Sallie and me. Tommy had gone away by himself some time before we started. We passed ever so many people coming away from our woods, and every one of them had bunches of Dogwood in their arms. Grandmother is very much displeased with the people who break off large branches from the trees. She says they are thoughtless, and have no knowledge of the harm they are doing. Most of them also throw the branches away before they reach their homes, as the flowers fade quickly. Grandmother thinks it will only be after they have truly learned to know flowers and to love them that they will stop being so cruel.

Philip Todd doesn't care sometimes how he treats flowers, and he carries such a large jackknife in his pocket that there's little he can't get. But we have all noticed that he treats Dogwood with great respect.

"It's this way," he said. "I once had enough of cutting Dogwood to last me my whole life. 'It was last summer when I had strayed into Uncle Hiram's woods." 


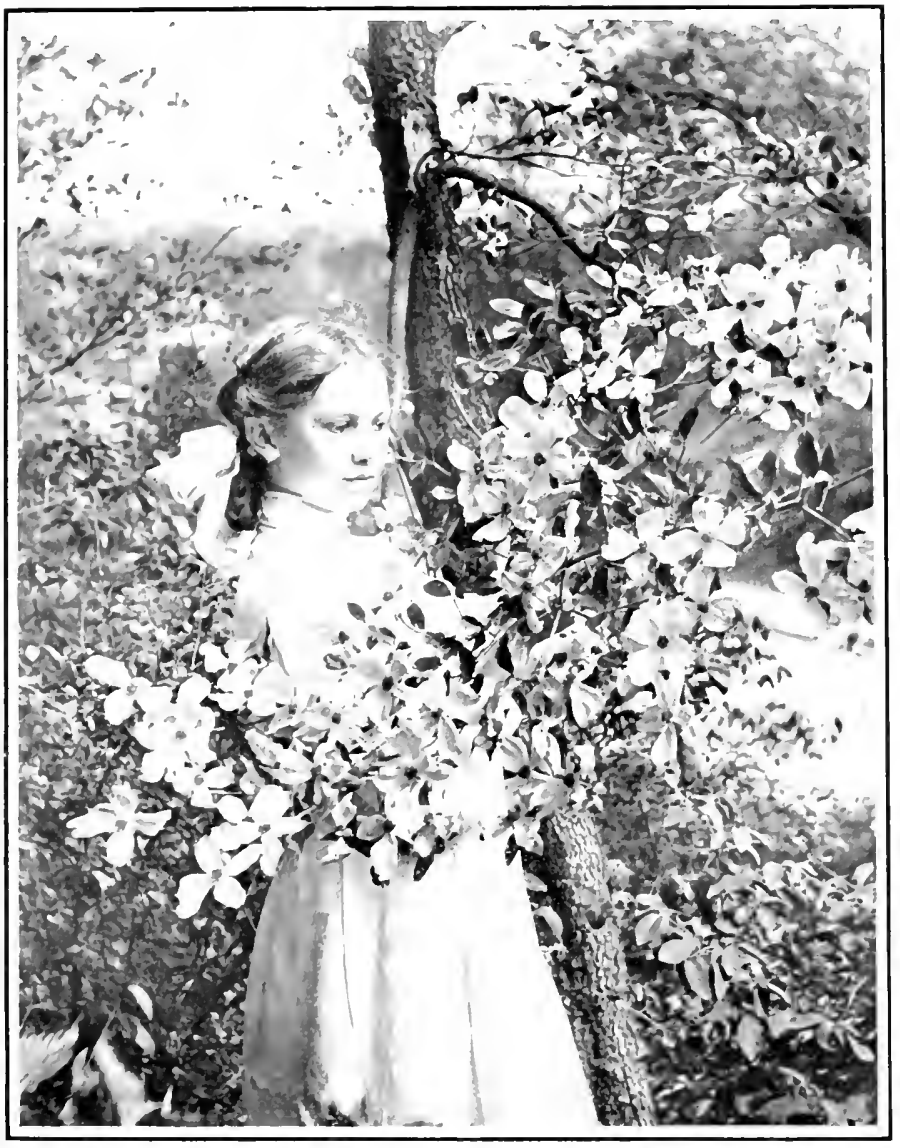

ILATE XV-SALLIE AND DUG WOOD 


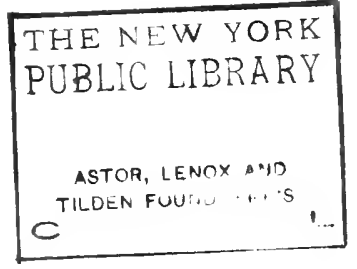


I began to listen very sharply, for he is the queer neighbor whom nobody likes, and yet everybody calls him Uncle Hiram.

Philip went on: "I climbed right up one of his Dogwood trees, took out my jack-knife, and had cut off three big branches when I heard a great, gruff voice calling out to me. I knew it must belong to Uncle Hiram. Before I could get down and run, he was under the tree, and held up in the air a monstrous shining saw. It was the biggest saw in the whole world.

" 'Come down from there!' Uncle Hiram called. 'Come down and let me saw your arms off; it's a good thing for such young chaps as you to know how it feels to be without a limb or two!'

"I wasn't frightened, of course, only I thought it best to stay up in the very top of that tree. It was more than half a day before I came down, and when I did I had promised Uncle Hiram never to cut off a Dogwood limb again as long as I lived. Uncle Hiram knows I mean to keep my word, and he talks with me sometimes now. He says I'll make a more useful man than if he had taken my arms off that day."

We were near Old Adam when Philip told us this story, and the sun was shining very brightly. The rock looked much whiter than on days when clouds hang over the sun. I was just telling Sallie that before she went home we were to have a picnic, and eat our luncheon on Old Adam, when 
I saw a girl lying down among the grass. A Dogwood blossom was in her hair, and a great branch of Dogwood blossoms drooped down over Old Adam.

I had never seen this girl before; but that very minute I felt sure she was the same one Tommy had seen in Secret Valley. Her hair hung straight by the sides of her face, and she never once moved, even when we ran up and jumped down on the other side of the rock. I asked Sallie and Philip if they had seen her there in the grass, and each said "no," which I thought very queer.

We went quickly to Tommy's house, for I wanted to tell him about seeing the strange girl. He said he had caught no glimpse of her, although he'd been sitting on the top of Old Adam for a good part of the afternoon. We both wondered then if what Grandmother had said was true, and if she could be the spirit of the Dogwood, as well as of Secret Valley. Tommy surely had seen her and so had I, and each time she was quite still.

"When I see her," Philip Todd said, "I'll call out something to make her move."

"Only this afternoon I saw an elf in a Dogwood nest," Tommy told us, quite seriously; "a smiling little elf, and one that asked funny questions whenever I went near."

But Tommy didn't deceive us, for we all knew the elf he meant was Little Trudy. 


\section{CHAPTER $\mathrm{X}$}

MORE FLOWERS, AND WHY TOMMY FELT ASHAMED

ONE of the strange things in the country is that sometimes when you are searching the hardest for a certain flower, you find another that you hadn't expected to see at all. Lately we have all been looking for Wake-robins, but each day passes without our finding them, and Grandmother is beginning to think they have vanished from this part of the country. This is, of course, because the people about here have already picked too many of them.

To-day when Tommy came he again shook his head about Wake-robins; but he had some other little flowers to show us. They were quite as fresh as when he picked them, for he had brought them home in the tin box he sometimes wears strapped over his shoulder. This box keeps the air away from flowers, and while in it they do not fade.

The Star of Bethlehem which he took out first is indeed like a star. It is just the shape of one, and bright yellow. But its leaves are so like grass that it would be hard to tell them apart, if it were not that the flower holds up its head and blinks so gayly.

Grandmother and Tommy didn't quite agree about the name of this flower; for she says that 
when she was a girl the plant we call Spring Beauty was known as Star of Bethlehem. Then Tommy ran home to fetch his books about flowers, and we all saw that he was quite right.

"Things are changed now," Grandmother said, "but Tommy, I do think your flower much more like the bright Star of Bethlehem than the sleepy Spring Beauty could ever be."

"Many people call it just Yellow Star Grass," Tommy answered, "only I think the other name is prettier."

Another flower that Tommy had in his box he called Bellwort. It also was yellow, but very different looking from the Star of Bethlehem. The blossoms were so pale that I thought them the color of straw, and two of them hung down from the top of each stem like little bells. The leaves hugged very closely to the stalk, without having any stems of their own, and they were a soft green color. Underneath them we also noticed a pale bloom, something like that on purple grapes.

I was just a little reminded of Dog's-tooth Violet when I saw this flower, although they do not even belong to the same family. I think this was because the flowers were something like pale yellow bells that fairies might ring.

Tommy had found it close to the Star of Bethlehem. There are many of them now in bloom, he says; but the one he brought home is to be pressed for his collection. 
This Bellwort has besides a near relative which he hopes to find in the woods. The way he will know it from the one he already has is because its leaves will clasp the stem even more closelyso closely that they will look as though they were pierced by the stem. The little bells then will hang out above these leaves, and as Tommy says they are fragrant, I think perhaps I shall care more for this relative called Perfoliate Bellwort than for the one which we have just seen.

There was a reason, Tommy said, that he seldom went to the woods where he had found the Bellwort, although once his favorite bunks were there. He meant the woods the other side of Uncle Hiram's, which belong to Miss Amelia, his mother's friend. It wasn't because he didn't want to go, he said, but because he once did something there that made him ashamed.

Grandmother asked him how that could be, and then he told us this story:

"Before last year," he began, "I had never seen a flower called Lousewort, or Wood Betony. $I$ had read about it, and seen pictures of it, and I knew besides that it was a curious wild flower. But I had never found it, although I had hunted for it much more than I have this year for Wakerobins.

"It's a flower that can't be mistaken. It's just one of the few that has a look something like an animal. You may think it very strange, but each 
of these little flowers that grow in a bunch together looks quite like the head of a walrus. It's yellow, or purple, or sometimes flowers of both colors grow on the same plant. The reason it looks like a walrus is because the upper leaves of the flowers stand straight up, and turn over in front. Then two tiny bits hang down like the long white teeth of a walrus. The leaves are something like a coarse sort of fern.

"Philip Todd told me one day that he had found it, and even showed me one of its pressed flowers, so that I might know he was playing no joke. Of course he kept its bunk a secret. The next morning I was up as early as I usually am on Fourth of July. It couldn't have been later than five o'clock. The birds were taking their breakfasts, and sipping at the spring in the meadow, and ever so many were singing in the bushes by the stream's side.

"I felt determined to find that flower, yet I hardly noticed where I was going. When I came to a turn, I didn't stop to think, ' shall I go this way, or that way?' I just somehow went. But when I did begin to think, I saw I was way down in Miss Amelia's woods, and farther away from home than I'd ever been, at least before breakfast. There was a fine old chestnut-tree in the woods, and I thought to lean up against it a few minutes to rest. Then just as I went toward it a little oven bird, or golden crowned thrush 
darted up and flew by me so swiftly I could hear her wings whizz.

" 'It's strange,' I thought, 'that little bird isn't out taking breakfast, or singing its morning carol.' But I knew also that when a bird starts up just in front of your face, she has some good reason for staying just where she is until the last minute before she expects to be covered by a strange foot. 'The lady has left her nest and eggs,' I thought, and then I looked about to see where they were.

"But now comes the strange part of the story. I saw two things at once: The Wood Betony and the nest of the golden thrush. In it there were five white eggs, speckled with brown. Perhaps it was the flower I saw first; but about that I'm not sure. Anyway the flower grew all around and above the nest, which was flat on the ground, and thatched over the top and almost hidden by some old leaves. You know the little oven birds build their nests so as to enter at the sides.

"I suppose I can never make any one understand how excited I was when I saw that flower. I forgot everything but that I had found it, and that it was there before my eyes. I forgot about treating flowers well, and that their lives are as dear to them as mine is to me. I forgot altogether about the little golden thrush. I just remembered that I wanted that flower. I stooped down and tore it up from the ground, root, nest 
and all. They were so woven together that one could not come without the other. I held them both in my hands. Then I heard a sharp voice crying, ' Cheep, cheep, cheep.'

"I looked up and there, on a bough, was the golden thrush. I felt her round eye looking me through and through, and all the time she cried, 'Cheep, cheep, cheep!' Things then got worse, for her mate had flown on the bough beside her, and he also made a great noise. They hopped up and down the bough, always crying 'Cheep, cheep,' and kept their round eyes on me till I felt more ashamed than I'd ever done in my life.

"I started to get away from that place quickly; but even after I'd turned my back on them I could feel they were still looking at me.

"I knew I'd nearly broken the heart of that little bird, and perhaps I should have quite, if her mate had not come to her so quickly to help her cry 'Cheep.' I felt sad enough when I walked away, and until to-day I've never been in those woods since.

"I had now and then taken one egg from a bird's nest. The hen doesn't mind that. She often lays another egg to take its place. But that day I tore up even the nest, just as though it were worth no more than a handful of dried leaves. That pair of little birds must have felt pretty badly when they saw me walking off with all they had in the whole world. For a long time 


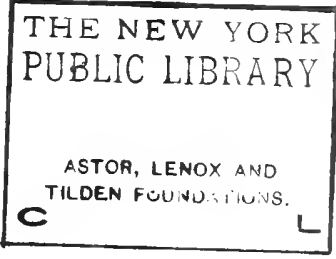




\section{WHY TOMMY FELT ASHAMED}

I kept the nest and eggs in my room. Then I traded them with Philip for a hornet's nest. The Wood Betony that I had stolen the nest to get, faded before I reached home."

"Even the sorrowful little birds must have forgiven you by this time," said Grandmother; " you will not do it again." 


\section{CHAPTER XI}

\section{COLUMBINE'S GLORY}

EVERY girl and boy, I think, has one flower which they care for more than any other. Francis loves the Arbutus best; my favorite is the same as Napoleon's, the Common Blue Violet; and Sallie cares most for the Rose. Grandmother says that great men also have had favorite flowers; and that among all the plants Lord Tennyson chose the Ivy, and Solomon preferred Balsam. The President of the United States wears a Carnation in his buttonhole; and the Emperor of Germany has an Edelweiss.

Nearly all nations have a flower for an emblem; and it does seem strange that America should have no especial one called her national flower. Perhaps this is because she is a free country, and there are so many flowers here people cannot agree to like one better than the others. America could not have the Thistle, for that is Scotland's emblem; nor the Shamrock which belongs to Ireland. The Lily represents France, and the Peony is the royal flower of China. A Chrysanthemum forms the imperial crest of Japan, and England's flower is the Rose. 
Now Tommy thinks that the Wild Columbine is the most beautiful flower in the whole of America, and that it would be much better for a national one than the Mayflower, which welcomed the Pilgrims, or the Goldenrod, which grows in every State in the Union. He says it is a flower that has true glory.

It is red and yellow, and nods over from the end of a slender stem, something as if it were a bell. Then the flower's leaves, or petals as I should say, are curiously folded together in the shape of horns of plenty, and the way their ends come together makes some people think of an eagle's five talons. This means power. The flower's full face is like a star with five rays, and when its center is seen in another position, it looks as if a ring of five turtle doves were there. These birds are emblems of peace, and Grandmother says this is why Columba, or Columbine, was chosen as a name for this plant, and that peace and power should be part of America.

It is a little like hunting for animals, or faces, in puzzle pictures, to see all these signs, but it is on their account that Tommy thinks Columbine would make such a fine national flower. Its leaves, besides, are very, very pretty. They are fine and graceful, like ferns.

Then what Tommy likes about Columbine is that it is so wild. It chooses to grow in the wildest places, usually by rocks, and to reach it we have 
often to take a high climb. Sometimes we call it Rock Bells.

Tommy's father hopes it will never be chosen as a national flower, because he thinks that if all the people knew it as such, they would pick it until it would disappear in one season. Already it is a vanishing wild flower, like the Arbutus and Dutchman's Breeches.

It is vanishing because, although every year it should make and sow its own seed, often each flower in a little group of plants is picked and then no seeds are sown, and the next year there are fewer blossoms.

The first day this spring that Tommy and his dog went to the well-known places where Columbine grows they found hardly any plants, and those they did find had a sickly, stunted look. This his father thinks is because they were too much picked last year. Next year perhaps they will not come up at all.

Tommy had a hard tramp with Peter that day, in high, rocky places, and sometimes over trees that had been struck by lightning. In the night there had been a great storm, and the sun had not yet come out very brightly. That day also Tommy heard hundreds of noises; not the kind that people hear in the city, though, screeching, rumbling noises, but noises insects make shaking their wings, and tall plants flapping, and birds chirping. 


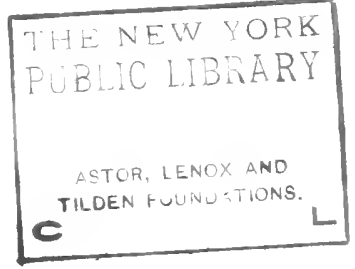


Peter loyes the woods best on such days and climbs to the highest places with his master. Sometimes they meet no one $w^{\prime}$ ' $m$ they know; but Tommy doesn't mind that, $f_{c}$ ne talks as much to flowers and to birds as he does to people. When he came to see Grandmother in the afternoon he told us about this long walk he and Peter had had, and then said:

"There's a bunk of Columbine not too high nor too rough for you to reach; and it's there, if anywhere, that you can see its full glory."

Grandmother said she should like to see it blooming at its best, and that there was no time like the present. So we started, Tommy being the guide.

What we had not expected was that he would take us into our own woods, for they are flat, with only the Bloodroot Ridge and Old Adam for a rock. About there now there are but a few Columbines.

We went on over the ridge, and soon Tommy bent down and crawled under some bushes. $\mathrm{He}$ held them up then for Grandmother to pass through, and I slipped under next.

Before this Tommy had shown me these bushes. They were Maple-leaved Arrow-woods, and higher than Grandmother's head. Besides, they were in bloom. Very many of their tiny white flowers grew together in flat bunches, and the leaves had almost exactly the same look as those of a young 
Maple-tree. They are beautiful wild shrubs, and are called Arrow-woods because their twigs are so straight, being without a bend, or curve. The Indians used them to make their arrows.

I had always thought that these Arrow-woods grew solidly in a clump together; but after we had slipped through, I saw they made only part of a circle and inside-well, it was just Columbine's glory.

The Arrow-wood bushes had hidden these Columbines so completely that perhaps for a long time not a single one of their flowers had been picked. Every year they had grown thicker together. Grandmother noticed at once that the blossoms here were almost twice as large as those near the top of Old Adam.

"This is enchanting," she said. "Tommy, you are right: Columbine's glory is here in this hidden place."

We all stood quite still, not venturing to move lest we should tread on the flowers. Then came a ruby-throated humming-bird, darting in and out among them, and looking as though he would whisper a word or two to each.

Tommy said: "He steals their sweetness. He sips the nectar that is in the flowers. See, he can poise himself on his wings and sip and sip; but that old bumble-bee must alight on the flowers. before trying to taste their sweets. His weight bears them down, and even then he cannot reach 
the nectar like ruby-throat with his long-pointed bill. It seems as though this humming-bird should be Columbine's mate, although nearby, perhaps, he has one of his own and fledglings.

The butterflies amid Columbine's glory could not keep still a minute, and when the wind came through the Arrow-woods, the whole company nodded and swayed their flowers and rocked to and fro together. After awhile they were still again, with only the ruby-throated humming-bird, the butterfly and the heavy bee visiting them in turn.

"We are invaders," Grandmother said.

"I'm the only boy that knows this bunk," Tommy replied, " and I've known it now for two years. It's hidden by the bluff on one side and the Arrow-woods on the other. There's just, I think, a dozen boys who'd give their best jackknives to know this place."

Grandmother asked him how he had found it, and then he told us. "It was when Peter was a puppy. He was just beginning to learn things, and had a way of poking into places of his own accord. One day he slipped right under the Arrow-woods where we came through. I thought he'd be out again soon; but even when I gave him a call, he stayed under. Then I parted the bushes to see where he could be, and he was just looking at Columbine's glory as hard as possible. In the autumn then father came up here and set in some other Arrow-woods, which now make the screen so thick. 
He says if the flower should vanish there will still be this secret place to show its full beauty."

"Even Philip Todd doesn't know I have this bunk," Tommy added. "I don't tell it because if these flowers were picked by all the people that pass through the woods, they'd soon have the same look of old soldiers without arms and legs, that those have about Old Adam. Nearly every one loves to pick flowers; but when some people see a Columbine it seems as though they must take the whole clump and carry the earth away as well.

"Father met a school-teacher in these woods one day. She had come out from the city, because she heard this was a good place for finding wild flowers. In her hand she had the largest bunch of Columbine that father had ever seen, and she had picked it all from around Old Adam. She said she was going to distribute it among her class the next day. Father then told her the harm she had done, and she was truly sorry. She said she didn't know that there were some wild flowers which shouldn't be picked. I thought that was worse than not knowing the queer things they ask in arithmetic."

Grandmother laughed. "Let us hope," she said, "that the school-teacher has learned her lesson, and that in future Tommy will know his."

Then we took a farewell look at Columbine's glory, and slipped away as Tommy lifted up the Arrow-wood branches. 


\section{CHAPTER XII}

THE LARGE YELLOW LADY'S SLIPPER

IT will be Tommy's birthday on Saturday and he is to have a party. Sallie is going with me, and Philip Todd will be there. Little Trudy has a new dress to wear and also one for her doll. Indeed we are all thinking what we can do to make Tommy happy.

Grandmother is going to give him a beautiful book about flowers and birds and Philip has spent all the money he had in his bank to buy him a kodak. Herr Wilhelm Fritz knows that Tommy's birthday is near and he is holding back some beautiful roses to send him in a basket. I have been thinking that I should like to gather Tommy a bunch of the wild flowers he loves so much, only he seldom picks them himself and it would not make him happy if I were to take him any that he thought were vanishing.

He has invited all the boys and girls that live near here, and has written to Francis to say that he would like him to come also. The only thing that makes him feel sorry is that he doesn't yet know the name of the girl with straight hair whom he saw in Secret Valley.

When Saturday morning came I heard Herr 


\section{LARGE YELLOW LADY'S SLIPPER}

Wilhelm Fritz whistling very loudly outside the dining-room window. He does that sometimes, and especially when his flowers are growing well. I called out to know if he remembered it was Tommy's birthday, and then he crooked up his finger and nodded in a way that made me think he wanted me to come out. I said I would as soon as we had had breakfast, and he called back, "rubber boots." Herr Wilhelm Fritz never thinks a girl can go anywhere unless she wears rubber boots. But I put them on before going out as there is not a single thing that Herr Wilhelm Fritz likes to be contradicted about. I thought he was just going to show me which flowers he had saved to send Tommy, only when we were near Grandmother's rose garden, he said:

"If little Miss like ter take ter der pardy der most wunderschoen of all der vild flowers, Wilhelm Fritz is der man ter know where it grows." He never says wonderful, because he thinks wunderschoen is " near enough."

I could hardly think what he meant. Before this he had always called wild flowers, weeds, and said he had better flowers in the garden. But when he asked: "Yer vant ter go?" I said yes, although I didn't know at all where we were going.

I waved my hand to Sallie and Grandmother, who were still at the window, and went on with Herr Wilhelm Fritz. He started off toward our 
LARGE YELLOW LADY'S SLIPPER 75

own woods, just as Tommy did when we went to see Columbine's glory. Herr Wilhelm Fritz is a very fast walker, and when he is going he never stops to look at anything on the way. He just walks and walks and walks until he gets there. When we came to the Bloodroot Ridge, he didn't climb up over it but kept on near the bottom, walking along its side.

We went farther down this way than I had ever been before, and he lifted me over the stone wall that divides Grandmother's woods from Uncle Hiram's. I said:

"Nobody is allowed to trespass on Uncle Hiram's property, the sign says so."

"Dat's all right: you vid me now," and Her Wilhelm Fritz laughed a very little.

He had carried a flower-pot all the way and a little trowel, and I felt really frightened to think that he might be going to take up something from Uncle Hiram's ground. The woods here were much thicker than Grandmother's; Herr Wilhelm Fritz said the trees had never been thinned out, and the weeds had grown wherever they pleased. He said Uncle Hiram couldn't tell a rose from a cabbage. Then he almost whispered:

"Little Miss, ve are near der spot. Ve are here. Vat you tink of sech flower as dat?"

Already Herr Wilhelm Fritz was down on his knees before the flower; and I slipped down on the ground the other side. There was only one 
flower, but it was even more wonderful than Columbine's glory.

"It's der Large Yellow Lady's Slipper," Herr Wilhelm Fritz said, "and it's an Orchid, just so sure as der ones Wilhelm Fritz tries so hard ter make grow in der glass house."

Its leaves grew out one above the other from different sides of the stem; and while larger, they were no more curious than the leaves of the Lily-of-the-Valley. It was the flower at the very top of the stem that was so wonderful. It was not like a real flower, but like an elf, or a sprite that nobody ever sees; for I think things that people only hear about are surely more wonderful than the ones they sometimes see and can touch.

The color of this flower was yellow, and at first I thought it something the shape of a tiny balloon. At its sides there hung down two curling sidepieces quite long, and narrow.

"Lady's Slipper," said Herr Wilhelm Fritz, "but strings untied," and he touched the little side-pieces.

Then he told me that the balloon-like part was one of the flower's petals which had taken that funny shape, and that the long strings were other petals.

"Wunderschoen, wunderschoen!" he said again; but not to me this time. He whispered to the flower.

He slipped his trowel all around it, and patted 


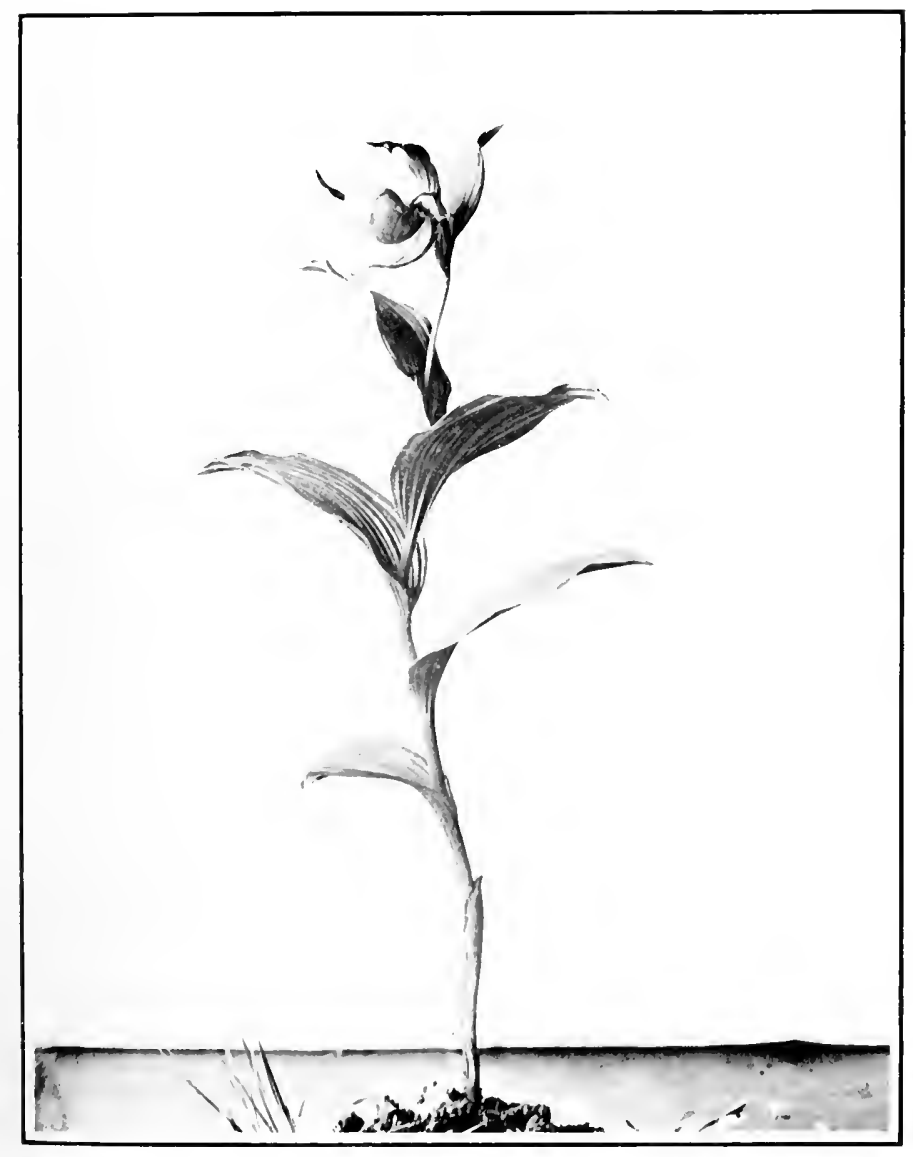

PLATE XVIII.-"TIERE WAS ONLY ONE FLOWER" 


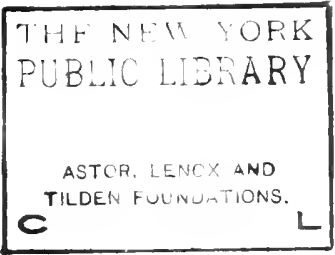


the earth about its roots and very quickly put it in the flower-pot.

"Oh, Herr Wilhelm Fritz," I cried, "we must leave it here. It is wild," for I thought he meant to keep it in the glass house.

"Ve fetch it back after pardy," he said. "It take no harm."

Then I knew that he meant to let me take it to Tommy, and I jumped and skipped about Herr Wilhelm Fritz all the way home, while he muttered to himself, and to the Lady's Slipper.

"Not like Orchids in glass house, but just so wunderschoen, just so wunderschoen," I heard him saying.

He called me back once and told me I must hunt every day for another Lady's Slipper, "wunderschoen pink, very like dis one, only it have but two leaves and dey come up from der ground, not out from stem. Very wunderschoen!"

$\mathrm{He}$ even told me I might find another yellow one almost exactly like the one he had in the pot, only smaller and a little bit fragrant.

I thought how delighted Tommy would be to see this rare flower, and what fun I should have in telling him it grew in a bunk of mine. Herr Wilhelm Fritz put moss around the pot, and when the time came to go I carried it to the party, and Sallie took the basket of roses from the glass house.

We were very early; but other children were 


\section{LARGE YELLOW LADY'S SLIPPER}

already there. When Tommy saw what I had for him, he rushed right off to get his book and to see if the flower were exactly the same as the Lady's Slipper in the picture. Then for the first time since we came to live in the country Tommy quite lost his voice.

"I know its bunk," I said; but Tommy did not speak.

"It's name is Large Yellow Lady's Slipper." Tommy said nothing.

"These are the strings of the slipper." $\mathrm{He}$ kept quite still.

"There's a pink one in bloom, very like it," I said, "and another almost the same, only the flower is smaller."

"Miss Wiseacre," Tommy said, and Sallie clapped her hands when he found his voice, "it must have been Herr Wilhelm Fritz who showed you that bunk, and who put the Orchid in this pot with the moss around. It's a beauty, and the best present I've had to-day."

"We are to take it back to-morrow and plant it in the wood again," I told him.

"Then you can fetch it again for my next birthday," he said.

Sallie gave him the Roses, and a very small boy who had just come brought him a silver pencil. He had many little gifts, but he ran away with the Orchid and took it to his own room.

When all the children were there we played 


\section{LARGE YELLOW LADY'S SLIPPER 79}

games and there were prizes. Little Trudy behaved very well until the mottoes were passed around, and then she upset the dish into her lap. She quickly gathered her dress up at the bottom and was running toward the door with them all when Tommy caught her and brought her back. He said that at the last party she went to she was so little that nobody passed her the mottoes, and he supposed she didn't wish such a mistake to happen again.

As soon as the party was over Tommy went to look again at the Orchid, and he found a big bumblebee held like a prisoner in its balloon-like pouch.

He kept the Orchid three days, and then he went himself with Herr Wilhelm Fritz and they planted it in its own place in the deep, green wood. Some day, Herr Wilhelm says, the flower will die and a large seed-pod will grow on the stem.

Philip Todd now goes with Tommy, and they look at it almost every day. 


\section{CHAPTER XIII}

\section{OLD ADAM'S GAIETY}

IN the city I am sure that most children think a rock like Old Adam can never be gay, because it does not skip, nor laugh, nor sing. It cannot choose which flowers shall grow about it, and even I, who am now almost a country girl, still wonder how it is that Old Adam never looks the same for many days together.

When March was here, it had such a solemn look that I scarcely could believe a tender wild flower would grow near it. Yet the Hepaticas were the first of all the flowers that seemed quite pleased to snuggle by the old rock. Near it we found them pink, which is their most lively color, while in Tommy's other bunks they were more often blue, or white. The Hepaticas, though, are such little flowers and grow so modestly that they didn't change the look of Old Adam very much.

When the trees began to open their leaves, and Butterflys' Banners grew on its top, and Violets were all around, I did think it looked more cheerful. Then when Dogwood and Columbine came Tommy said it was getting frolicsome. They both grow by the side that slants down, and 
. 
is not very high from the ground. Now its highest side is having a turn of gaiety, for lately flowers have opened there which fairly cover it, and the old rock looks as if it were smiling.

The name of these flowers is Rock Pinks, or Wild Pinks, which sounds as if they were really meant to grow on a rock. They are a deep, deep pink, and against Old Adam's gray side they shine out very brightly. They look something like oldfashioned garden Pinks, although their five petals have each but one notch in the middle.

The leaves that grow in a circle about the stem where it touches the ground, are narrow and rounded, and I saw they were quite different from the smaller, pointed ones that grow on opposite sides of the stem. Besides, when I picked these flowers and had the stems in my hands I found out that they were sticky.

Since we came to live in the country I have learned to notice when flower stems are covered with this sticky stuff; for it is to keep little insects from crawling up them and eating the flower's nectar. These mites like very much to sip sweet things; but they are not like the good bee and butterfly, and don't know about carrying the golden dust. Wild Pinks can only save their nectar for butterflies by gumming such little insect crawlers close to their stems and holding them there until they die. I hardly think this matters much; for they are very ugly, and not much use to any 
one. One day on a Rock Pink's stem, and close to the flower, Tommy counted over forty little mites which were quite dead. Only two of them were much larger than the head of a pin. I have noticed, too, that when I hold them in my hand, Rock Pinks do not look nearly so pretty as when we see them growing by the gray rock.

It is not only about Old Adam that these flowers are blooming. Quantities of them are out in other parts of the woods, and on some high banks along the roadsides.

By Old Adam Columbine is still swaying, swaying its red and yellow bells as a jester nods his cap, and beautiful ferns, and plants with leaves like ferns, are growing there. Of course Dogwood is still hanging down over the spot where I saw the strange girl; and even when the woods are dark the sun peeps in and sits there like a crown.

One of the flowers, with leaves like ferns, is called Early Meadow Rue. I have often passed it on my way to the rock, and yet it was only yesterday that I asked Tommy its name.

"We'd miss it about Old Adam," he said, " if anything should happen to drive it away. Its flowers don't look very pretty; but it's just such plain little things as they which sometimes are most curious. They are only a greenish color, and you see how they grow in long, loose bunches 
at the ends of the stems? They haven't what I call a real flower look. I mean they're not beautiful, delicate things which make you want to look at them more than you do at the leaves. I've seen some grasses that were just as pretty as these little blossoms.

"But the odd thing about them is that they're of two sorts. Those that are the least pretty are the girl flowers, and the ones that have so many little yellow things standing out and holding the golden dust are their mates, or the boy flowers."

I asked Tommy next if there were anything queer about the Early Meadow Rue's leaves.

"Only that they are divided up into so many round, little leaflets, with notches in their ends," he answered. "They have a purple, pinchedtogether look before they unfold. Sometimes I have almost mistaken them for Columbine's leaves. Then the plant is all about in the spring woods, and when Rock Pink and Columbine blow we pass it nearly every tramp we take. It's best to know its name, and some time you might pick a sprig of it to put in a bouquet,- that is if Herr Wilhelm Fritz had only a few ferns and wouldn't let you have them."

To-morrow will be the last day of Sallie's visit. We have not done nearly all the things we thought we would, although the only one we much regret is not having the picnic, and eating our luncheon on Old Adam. But it has been raining hard, and 
the earth is still very wet. The sun has only shone out again a little this afternoon, just enough for Sallie to run out and say good-by to the flowers and places she has known since being here. She wanted to fill a box with some of the earth about Old Adam, so as to take it home and plant it with seeds. She thinks then they cannot help sprouting and growing.

Sallie is going from here to the seashore. She will bathe in the salt water every day, and dig in the sand; but there are no woods near-by, and the children there hunt very little for wild flowers. Grandmother thinks though that if she looks in the sandy fields and green places away from the water, she may find very many beautiful flowers. Not just the same kinds as those that grow here perhaps, but others that love sandy soil, and to sniff the cool, salt breeze from the ocean.

Since Sallie has been saying good-by to the Rock Pinks she has written a great deal down in a note-book which she keeps tied to her belt. I have not seen what she has put in the book; but I feel sure it is something she wants to remember, and perhaps she will write compositions about it all next winter. She says she has intentions about wild flowers, only she can't tell them yet.

I think she must have written Old Adam's history and how the rock looks now that its high end is almost covered with Pinks; and also I think she has written about Dogwood and the tissue-paper 


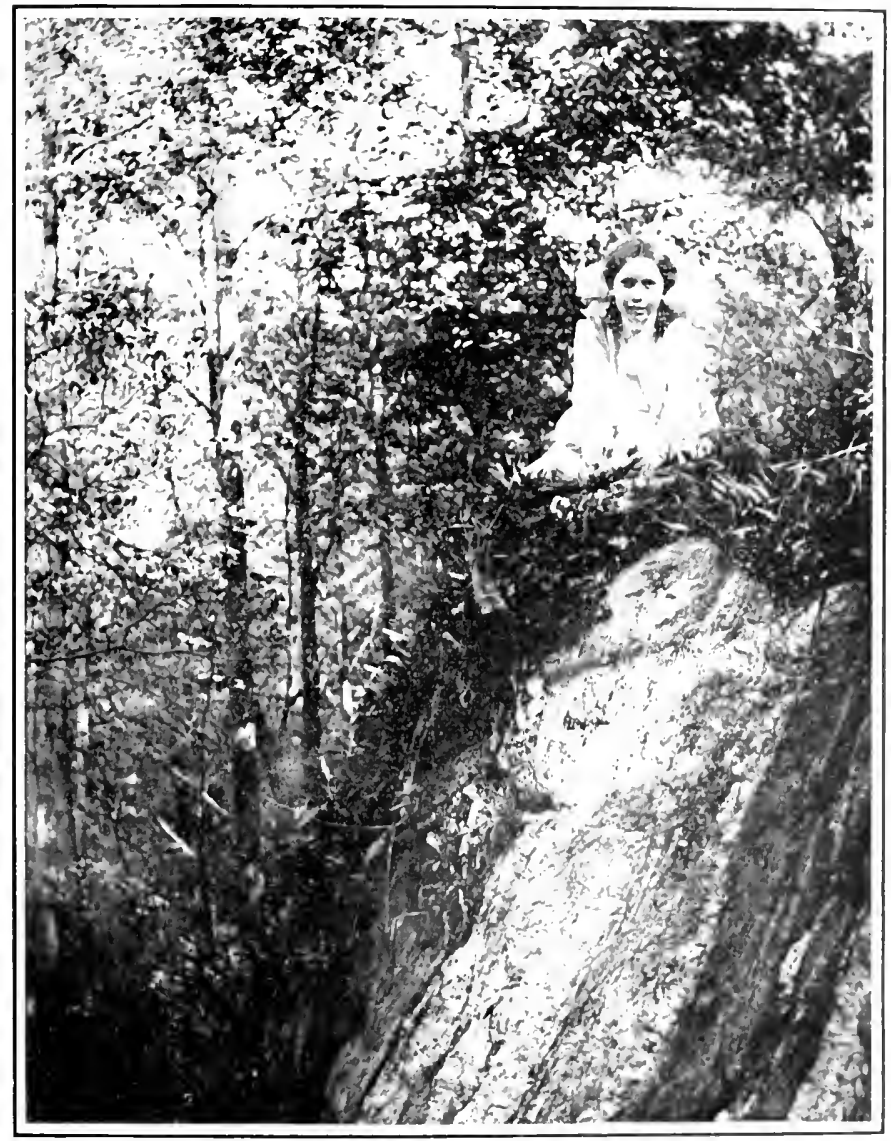

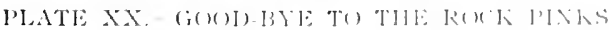




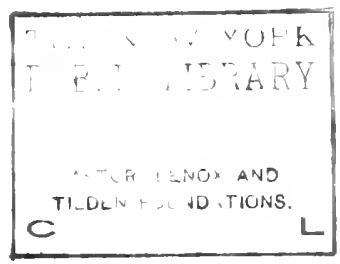


leaves she found under Bloodroot, and perhaps about the Orchid I took to Tommy's party.

Tommy and Philip Todd are both going with us when we take Sallie to the station. Her father is to meet her at the other end of her journey, and this is fortunate, for she has so many things to carry. Philip has given her a rabbit, a pretty little creature, almost all white, and which keeps his nose moving every minute. His eyes are bright pink. Herr Wilhelm Fritz has some Roses and Carnations for her; and Tommy has given her a dear little Pine-tree to plant at the seashore. It is hardly as tall as the rabbit when he sits up, and we all think that it may grow if she puts it where it is not too windy and a little shady. Then, of course, she has her box of Old Adam's earth.

Grandmother thinks Sallie's intentions are more about this earth, and the wild flowers she will try to grow, than about writing compositions at school next winter.

Herr Wilhelm Fritz said to-day that we were not likely to see Old Adam looking half as gay again this season as he does now when the Rock Pinks are blooming. 


\section{CHAPTER XIV}

THE FIND BY THE ROAD, AND LITTLE PIPES

After Sallie had gone I felt very lonely. For some time I could not be quite happy, although Grandmother reminded me how beautiful the country and the flowers were, and of many things that I had yet to do. It was in the house that I felt most lonely. Out in the sunshine I am always gay.

Sallie sent us a note from the seashore. It was written the first evening she reached there, and was very short, so we know nothing more about her intentions, nor how the seeds are growing in Old Adam's black earth.

To-day it is warm for May, and although flowers are blossoming all over the woods, it looks as though the weeds were growing faster. They are getting tangled in among themselves, and some are crowding the flowers out of their right places.

There is something very impertinent about these weeds; but Tommy says for me to wait until midsummer and see how they act then. That will be the time when nobody can get ahead of them. They are not exactly troublesome just now; only it is much harder to find small flowers than before the weeds were grown. Besides, they cover the ground so that I might easily put my feet down on 


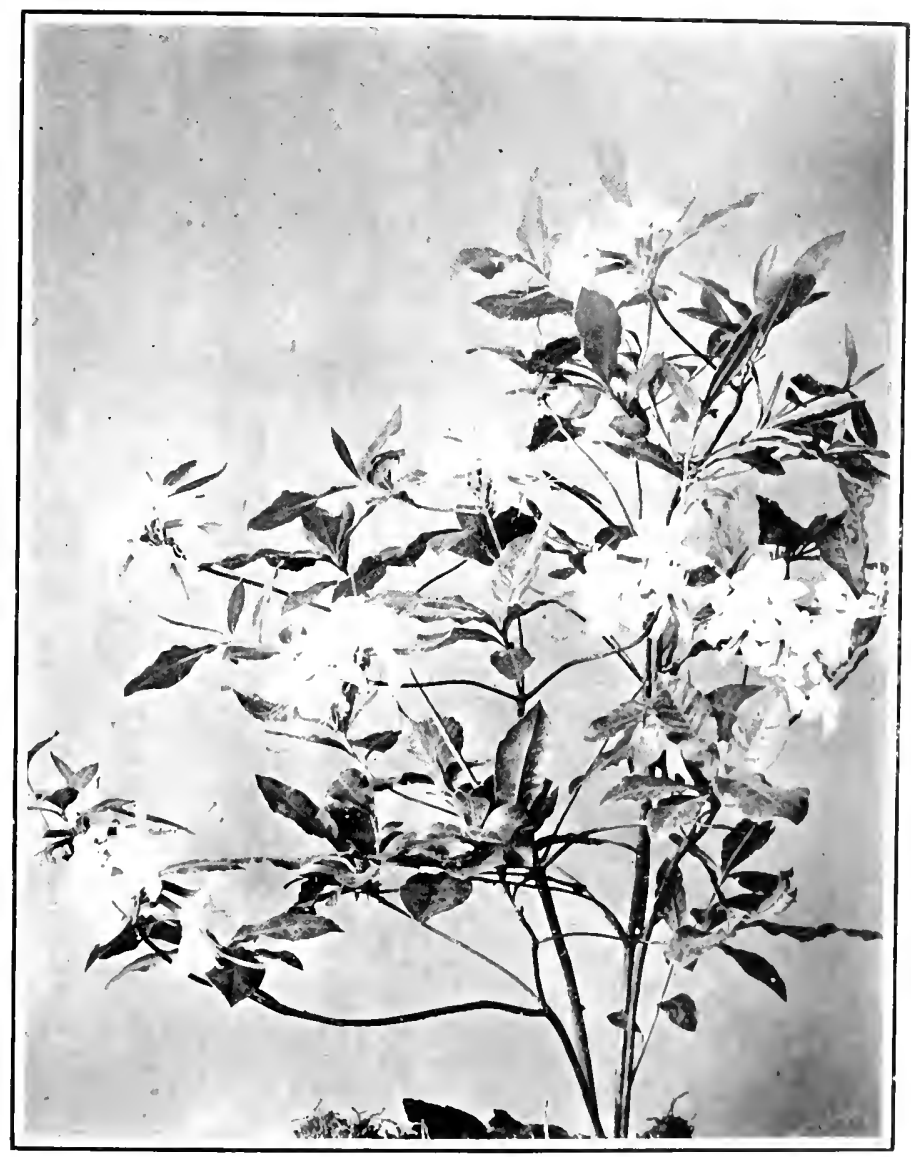

PLITE XXI PINK AZ.ILIA 


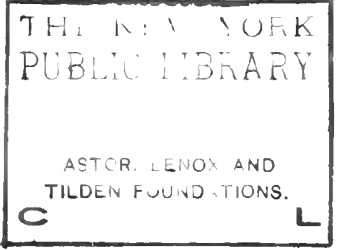


a snake. I have never seen one of these creatures yet; although once in the road Tommy showed me a mark which he said had been made by one that had just crossed. It only looked to me as if a stick had been dragged through the dust.

Yesterday when I was driving with Grandmother we found something that quite put the thought of snakes out of my head. This was a flower that grows on a little bush, and is very beautiful. It is called Pink Azalea or Wild Honeysuckle.

When we found it we were not looking for fowers. We were just driving along the road in the afternoon, as Grandmother docs nearly every day. I had gone with her because I was feeling so lonely without Sallie. At the part of the road where we were, Miss Amelia's woods come nearly down to its edge, and the bank is quite high. Already we had passed a few Rock Pinks blooming on the bank, and then suddenly I cried, "Look, do look, Grandmother!" I knew even then that the flower I saw was a different one from any we had found in the country. It was just like the beautiful Azaleas that florists have in the city and which people send to their friends at Easter.

We had gone by so fast that Grandmother did not see the flower. So Patrick stopped the horses, and I jumped out of the carriage and ran back. I climbed up the bank and just as I had 
thought, the flowers grew on a little bush and looked almost exactly like city Azaleas. They were a real rosy pink, and the little centerpieces grew out very far from the flowers. The name of these little things, Grandmother says, is stamens, and the one in the center is called the pistil. These names are not hard to remember, and perhaps if I use them people will know better what I am talking about than if I call them "little things." The flowers had the faintest kind of a sweet scent, and the leaves, which looked very young and tender, grew together in little bunches on the twigs.

I put my arms around the little bush, and had I not feared to crush the flowers, I might have given it a good hug. Then Grandmother called, and I climbed down the bank again, taking her a little sprig of the bush.

She was delighted. "It's the first one I've seen growing wild for a long time," she said, " although years ago when this road was cut through we used to call it Wild Honeysuckle Path, because these flowers bloomed so thickly along its banks. Run back and look a little farther through the underbrush, and see if there are not other bushes hidden from the road."

I climbed the bank again and when I had slipped under the barbed-wire fence which Grandmother had not seen along its top, I was quite in Miss Amelia's woods. I hardly hunted then 
a minute before I saw more Pink Azalea bushes. The flowers beckoned to me, and I stepped quickly where they were. A little company of them grew together, and I wished that Grandmother could climb the bank and look at them there. I knew I could never tell her how beautiful they were with the sun shining on them in little round spots. I called out to her, but then I remembered the barbed-wire fence. I picked a few sprays of the clustered flowers and leaves, and went back to the carriage. Patrick soon drove on, but not before both of us had noticed that the spot where I slipped under the fence was just opposite a large Buttonball-tree.

Grandmother said: "It's well, child, you picked only a few of the Wild Honeysuckles, for they, too, are vanishing since the road has been here. I grieve to think what will happen when a trolley line is built."

Tommy had already seen these flowers. He has a bunk for them, although it is not the one which Grandmother and I discovered to-day. What he doesn't understand is why they are called Wild Honeysuckles. They look different from true Honeysuckle flowers, and are very much like Azaleas. Another name which he knew for them is Pinxter Flowers, and what this means I have no idea.

Tommy quickly picked a little lump off the side of one of the twigs that I had brought home. 
"What is it," I asked, as he put it in his mouth.

"It's a May Apple," he answered, " and has about the best taste of anything that grows this month."

I thought that the next time I found one I would try it myself.

The other new flowers we have had since Sallie went away, Tommy calls "Pipes," because their real name is Naked Broom-rape and that isn't half as like them as Pipes. When we hold them up lengthwise of the stem they look as if they might be used for smoking. This would not be by real people, of course, but by little woodland folk that perhaps know the flowers, and have ears sharp enough to hear them talking.

There are no leaves on these Pipes, and this seems strange, as leaves are one of the things flowers usually have. A sort of roughness grows along their stems, and these, like the flowers, are faintly blue. The Pipes grow down in the grass of the woods, and soft, wet places, just as though they were timid about peeping out too far.

Those that Tommy saw first this May were brothers and sisters, I think, in the same Pipe family, for four of them stood up together like steps. There were also buds among them, striving to reach as high as the others. I could only feel sure they were real flowers and not makebelieves, when the little one turned its full face. They remind Tommy of the Indian Pipe, or Ghost 


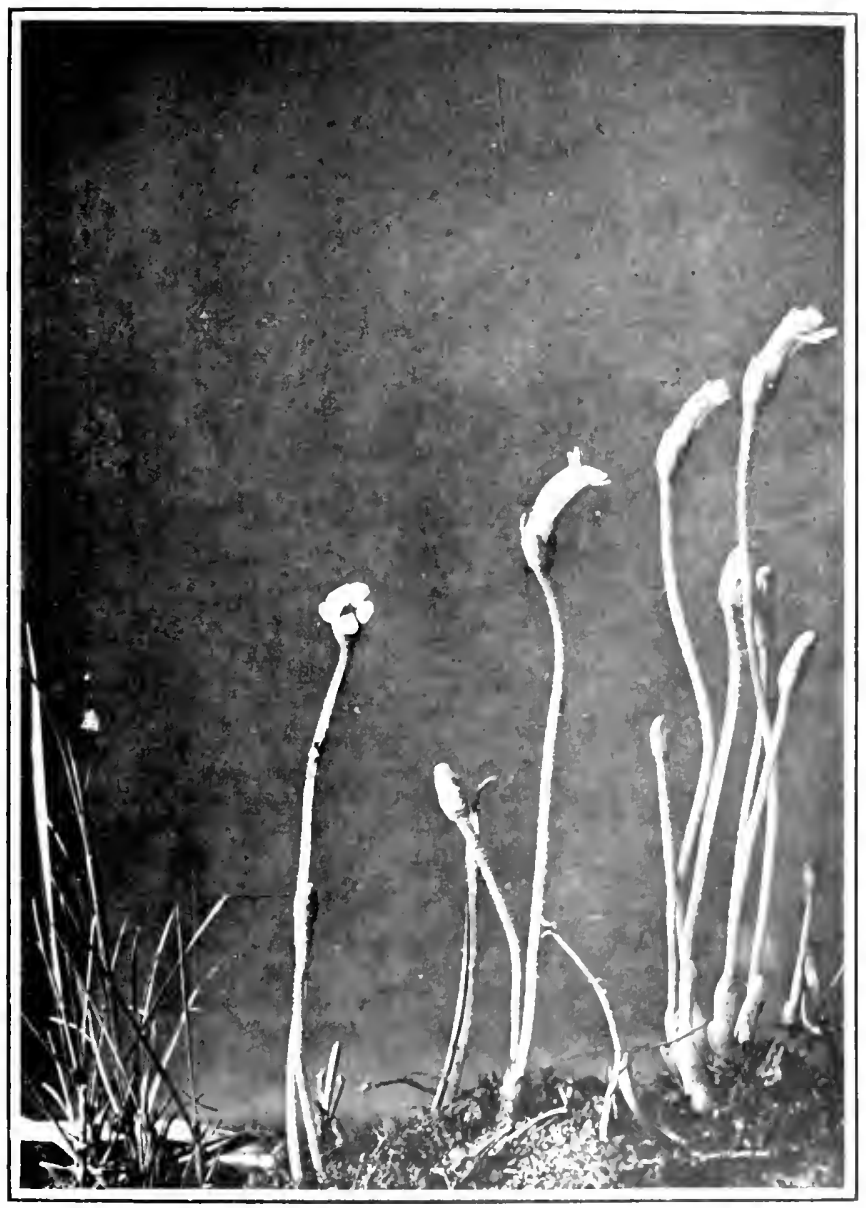

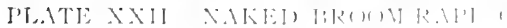




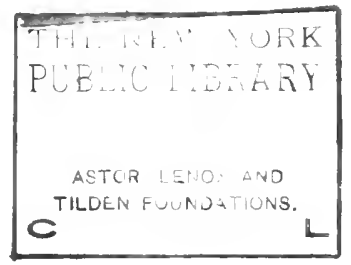


flower, and which must be the one Francis told the story about. Indeed Grandmother thought when Tommy talked about them that he had simply found a company of Indian Pipes, until he told her they were as blue as though Dame Nature had no other color. He said: "They're a soft sky blue."

While Tommy chatted I could not but feel sorry for the four little Pipes. All the flowers that grow about them have leaves.

"They must feel very strange," I said.

"Not at all," Tommy answered. "That's just their way of growing." 


\section{CHAPTER XV}

WILD GERANIUM AND POOR ROBIN'S PLANTAIN

WheN Wild Geranium blooms it does seem as though it wanted to be everywhere. It isn't content with staying in our woods. I can see it all over Uncle Hiram's little hill; it fairly covers Miss Amelia's field, even Tommy's bunk for Wood Betony; it is out blossoming along the roadsides; in the field where there are cows, and it grows rather close to the stream. The color of its flower is lavender, and it is frail and pretty.

It is not exactly the shape of a Buttercup, nor a Wild Rose, and yet it is a little like each. Wild Geranium is smaller than the Rose, and larger than a Buttercup. The flower grows alone, or a few of them are together at the ends of rather thin stems. The leaves remind me of the Geraniums that live in glass houses, or out in the garden in summer, only they have no spicy fragrance.

Sometimes, as they begin to fade, white spots come on a few of them. Besides, when the flowers have fallen, and the seed-pods are made, there is a long piece sticking out which some one must have thought looked like a crane's bill. It is because of these white-spotted leaves, and this long part of the seed-pod that the plant is also called Spotted Cranesbill. 
Tommy says he has found these leaves a deep wine-color and very brilliant quite as often as white-spotted, but this would not be before midsummer, or in the autumn when strange changes pass over all the flowers and leaves.

It makes me sad even now in May to think that flowers and leaves must all fade, and the earth again grow bare and cold. So far, since we have lived in the country, and since Hepaticas bloomed, just as soon as some pretty wild flowers were gone, others unfolded to take their places. We see Wild Geranium much more now than Spring Beauty, whose head is heavy with seeds; and other flowers have come with Wild Geranium which were not here with Rue-anemones, or Bellworts, or the Wood Betony. The Geranium is friendly with Rock Pinks, and of ten I see the two growing in the same places.

I think that if we saw fewer Wild Geraniums we would care more for them. They are not a bit shy and hiding like the Orchids, nor wild and fearless like Columbine. They just seem to want to grow everywhere as though they were weeds.

Tommy chatted and chatted one day about Black Snakeroot until Grandmother asked him what kind of a plant it was. Then we found out it was Wild Geranium, and that this is simply another one of its names. It has many names, just as it loves to grow in many places.

Grandmother told us also that in the south there 
are several plants called Black Snakeroot. People who live far away in the mountains, and who see almost as many rattlesnakes as they do strangers call them by this name, or else Rattlesnake Master, because they think the bites of these creatures can be cured by their leaves and roots. But Grandmother had never heard this pretty flower called by Tommy's name of Wild Geranium, and she thought it a poor one, even though the leaves have a look like the Geraniums in the garden. Two very old country people whom Tommy knows always speak of it as Alumroot. This is because its roots have such a bitter taste.

I said that if I had a pretty flower to name I should never think of looking at its roots first, nor of tasting them. Tommy answered that roots were very wonderful; but, of course, he thought girls would not care for them because they were not as pretty as flowers.

Both Tommy and his father belong to a society for protecting wild flowers, and one of the rules is that flowers must not be taken up by the roots for fear of their vanishing. Still they both think it would do little harm if the country people were to gather a few Wild Geraniums to use instead of alum, or to cure snake-bites.

Tommy says: "It all depends on the plant whether or not it should be taken up by the roots. Of course it would have been very dreadful if 


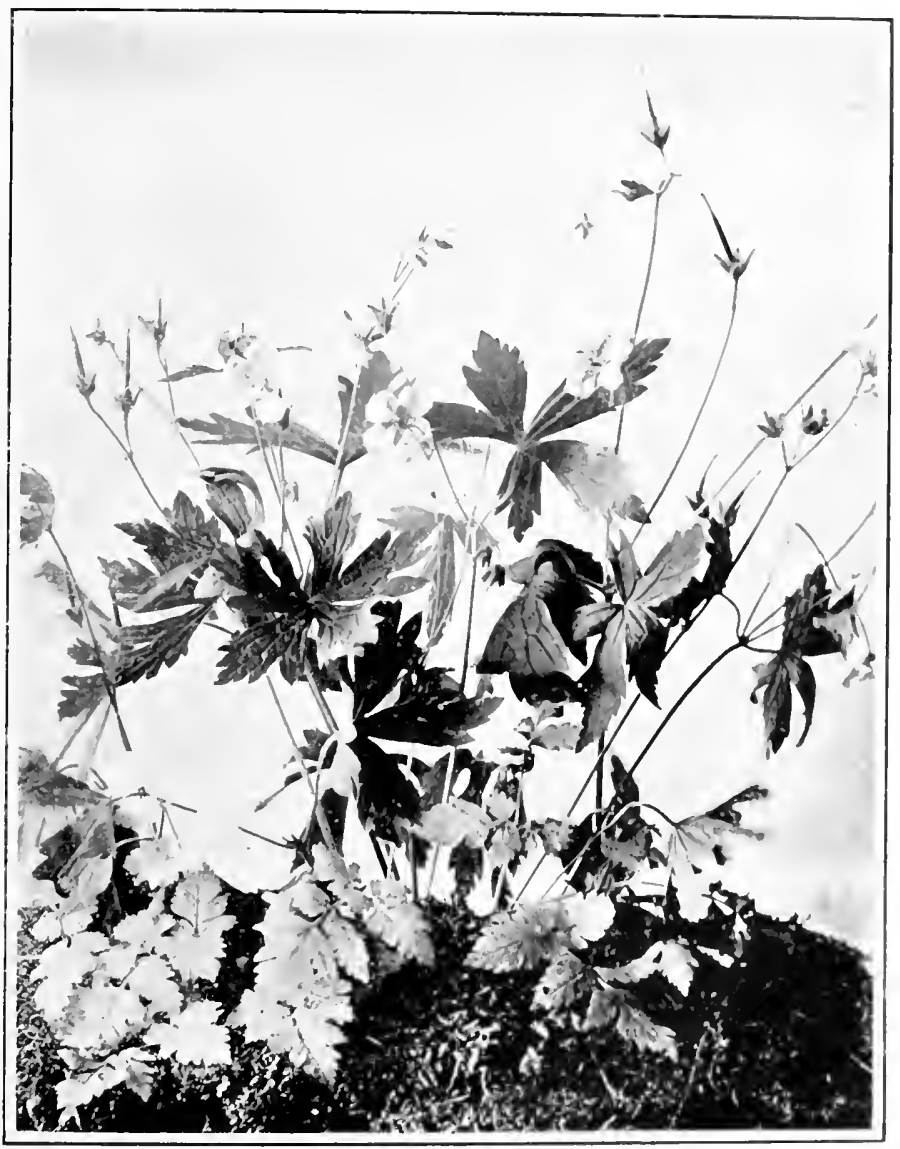

PLATE XXNII. WILI GERANILA ANI TIIE WIITE FIER 
. 
Herr Wilhelm Fritz had not carried the Yellow Lady's Slipper back again to the woods after my party, and planted it in its own spot, because it is so rare and already vanishing. But the Wild Geranium is as far from being rare in this part of New York State as Goldenrod, or Daisies. It isn't picked enough either by country children to make it vanish, because they know how soon it fades. Strangers to the woods are sometimes pleased with its pretty face and take it away in great bunches.

"The flowers," Tommy went on to say, "have a queer little way of scattering their seeds. When these are ripe, the long cranesbill pods burst open and out they jump in many directions. They open just as though they were made of elastic. Sometimes I have given them a little crack for the fun of seeing the seeds pop out."

The clump of Wild Geranium that I like more than any of the others is near Old Adam, and beside it there are many little fern leaves which are quite white. Tommy docsn't understand about these little leaves being so white when all the other ferns are green. This is something he is going to ask his father about.

When we went last along the little path that leads to the village, and which is a short cut across the back of Tommy's place, he stopped a minute and called out:

"So here you are, Poor Robin's Plantain!" 
I looked about to see what he was talking to, for often he says a few words to flowers, although he knows that they can never answer him. A tall flower stood close by the path and looked to me very like a Daisy, only it was not pure white, but a pale violet color.

"Let me present Poor Robin's Plantain," Tommy said, and he made a bow.

I made a curtsey, keeping my back very straight. "Have you met before?" Tommy asked.

"This is the first time," I answered.

"He's a friend of Wild Geranium," Tommy said.

"Then we shall see a great deal of him," I said.

We both laughed then, for we were acting just as we do in dancing-school, only there was no one to see but the flower that looked like a Daisy.

"It isn't really like a Daisy," I said when we were serious again. "See the woolly white hairs on its stem, and they quite cover the leaves. I see too that on the ground the leaves grow in a round tuft; the ones on the stem are smaller and pointed."

"Right," Tommy said, "all those things are true about Poor Robin's Plantain. It's really more like an Aster than a Daisy. It goes to seed and looks gray like an old man almost before Daisies have come, long before its Aster friends of the autumn are here."

After awhile Tommy said: "Perhaps that's 


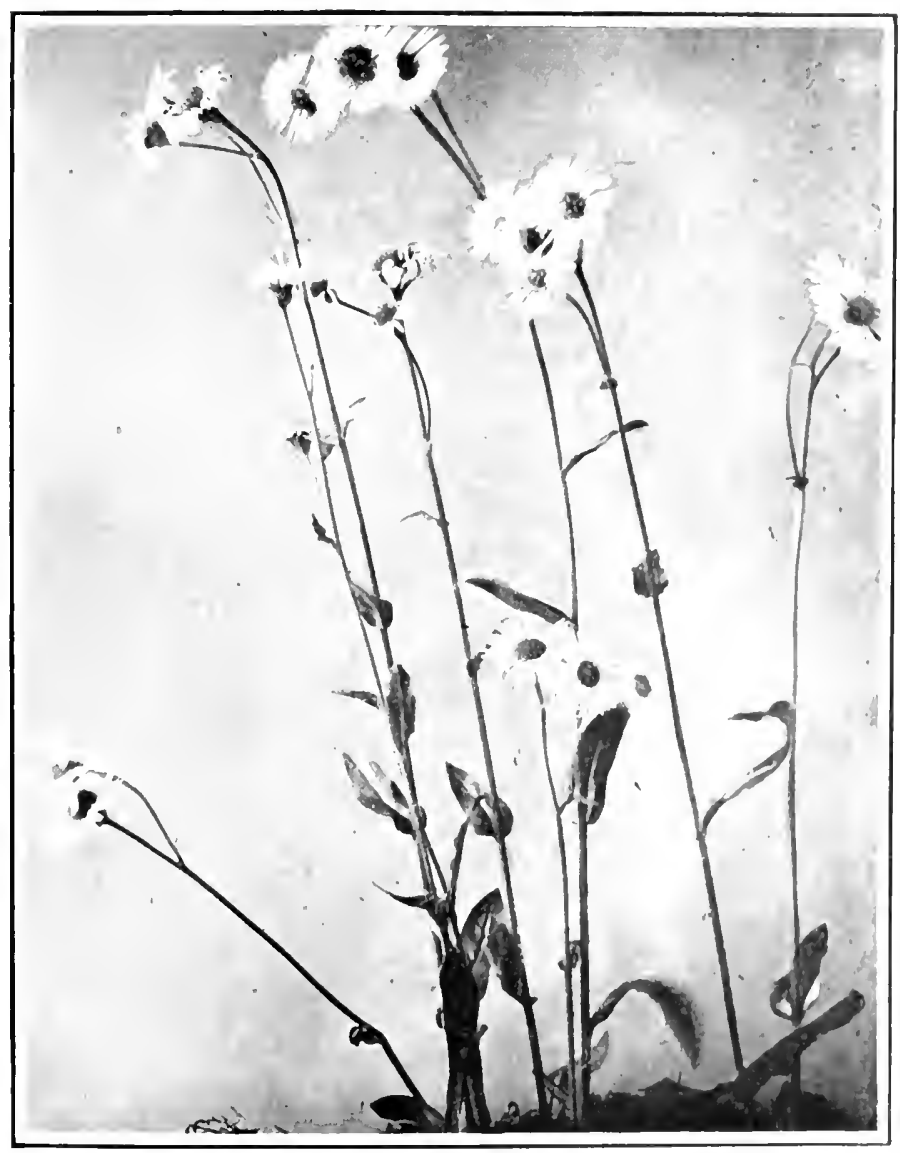

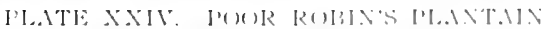




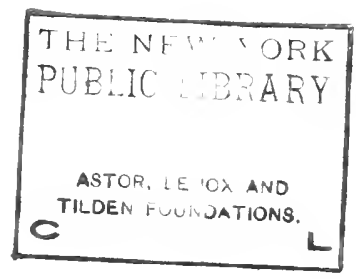




\section{POOR ROBIN'S PLANTAIN}

why it's called Poor Robin's Plantain. It's here before its true friends, although Wild Geranium is like a companion to it since they grow usually in the same places. They're not one bit alike, however, and belong to different families. Yet it has hundreds of near relatives which don't come until it's old and gone to seed, dead perhaps."

This did seem very sad. I told Tommy I should be Poor Robin's friend, for I had no brothers, nor sisters, nor any family but Grandmother.

We went on to the village then and came back through our own woods. Here we saw a few more Poor Robins, and one of them had grown up as tall as I. The others were shorter. Wild Geraniums were all about.

Each day now the woods get more full of green leaves.

"When Poor Robin's relatives come in the autumn there'll be hardly a flower left here," Tommy said. "We'll do all our hunting then out in the open, by the roads and in the ficlds."

I couldn't quite make out why, when it is only May, Tommy should want to talk so much about the autumn. Summer has not even begun. He "sees signs," he says, and by this I suppose he means that a Wild Geranium's leaf has turned to bright red and that Poor Robin's Plantain is here before its relatives.

After I have lived in the country a long time 
I may begin to know the leaves and signs as well as Tommy. It isn't only all the things that are here, he sees; he seems to see others long before they come. I hope he won't go on seeing autumn things for a long time yet. I love best to think of the summer, when Wild Rose will bloom, and of the bright warm sun that is shining to-day. 


\section{CHAPTER XVI}

PHILIP HEARS ABOUT THREE NEW FLOWERS

IT is the last week in May. In Grandmother's rose garden there are pink, and white and red buds all swollen and ready to burst out, and two Roses are in full bloom. Herr Wilhelm Fritz is very proud. He says: "Little Miss vill no more go to voods fur der vild flowers, but vill step into peautiful garten." I should like to visit Herr Wilhelm Fritz in his garden very often, only it is much more fun out in the woods. Grandmother goes to see him and talks with him every day, and as long as he has his flowers he is never lonely.

The woods are very gay now, and some new flowers are there that I have just begun to know. Tommy thinks that after they have faded the woods will look more green, but not so pretty again until spring comes back.

Philip Todd has been away for a week. He went with his mother to visit an aunt where he told us he had six girl cousins. Now Philip's mother calls him her little lamb, and nobody ever heard of his being punished; so Tommy is wondering how he enjoyed himself when he was visit-

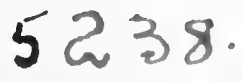


ing, and had to be polite, and give in to all those cousins.

He came back yesterday looking more sunburnt than ever. He says he had a famous time, and that all his cousins are coming to Warley Towers to see him. "They must all come together," he says, " and not keep spinning their visits out one by one the whole summer. They're only funny when they're all together."

Tommy asked him how they looked and what their names were. $\mathrm{He}$ answered that they all looked like Kitty Contraries, instead of Mary Quite Contrary, and said that if he had to sing about them he shouldn't mind a bit. He said he called them whatever names came in his head, because six real names were too many to remember. When he especially wanted to make them hear he called out, "whizz, phizz."

"They made green eyes at me," he told Tommy.

Then Tommy asked what were their ages.

"All about the same," Philip answered.

"They can't be," Tommy said.

"They are," Philip persisted.

Then we both knew there was something wrong with those six girl cousins, but what it was we couldn't find out.

We sometimes go to see Mrs. Todd when Philip is in one of his joking moods, but yesterday we knew she was away from home. 


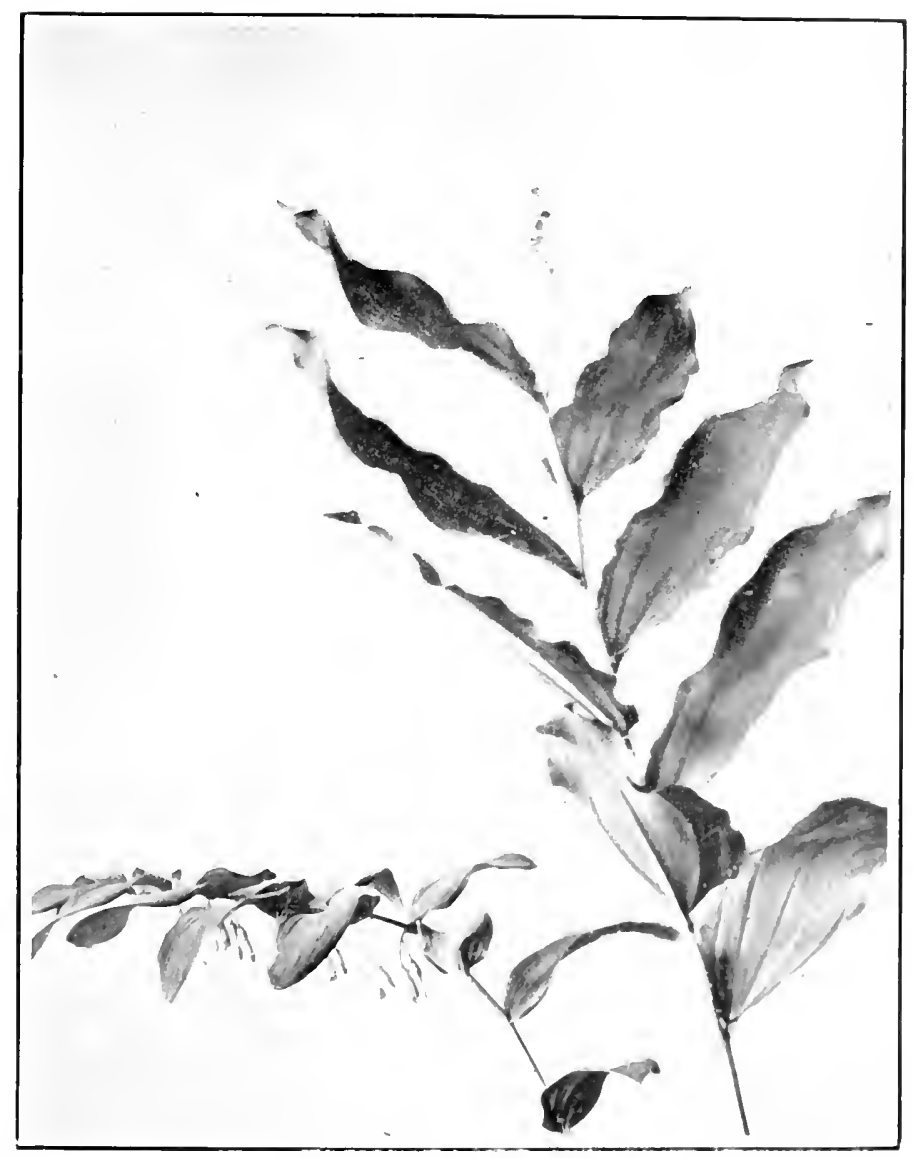

PLATE XXV. THE TRLE ANI) TIE F.MLE SOLOMUN'S SEAJS 


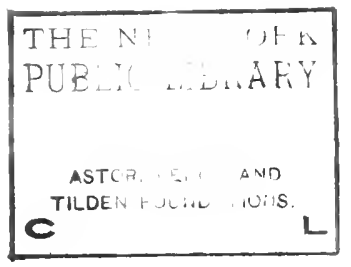




\section{THREE NEW FLOWERS}

To-day Grandmother and I are going to Philip's for luncheon. Afterward perhaps I will take Philip in the woods to show him what flowers have bloomed since he went to visit his cousins.

When Grandmother and I were there at last and waiting for luncheon, Philip said: "I saw from the train window coming home that Wild Geranium is out, and that Rock Pinks are still here. I suppose Poor Robin must be open by this time."

"It is indeed," I told him, and then I said that there were other flowers besides which perhaps he didn't remember.

"Let me guess," he said. "There must be Solomon's Seal, False Solomon's Seal and False Lily-of-the-Valley. He called out the names very fast and as though he were a parrot.

"Perhaps Tommy told you," I said.

"Perhaps this is not my first year in the country," he replied.

"What is each one like," I asked, for there was still time for him to tell me before luncheon.

"Well," he began, and I knew he was imitating Tommy, "they're plants that you can't miss seeing in the woods."

"That's true," I said, "go on."

"They're all related."

"They are, but how do they look?"

"Like plants," Philip answered. I was glad he had given up mimicking Tommy. 


\section{THREE NEW FLOWERS}

"Now I will tell you how they look," I said, "for I see you have never noticed them for yourself."

"I was thinking of my six girl cousins," he interrupted.

"Solomon's Seal," I began, for I had learned about these wild flowers from Tommy, "is the true one of them all. It is never called false. It looks like a long, bended, double spray of green leaves. The double look it has is because the leaves grow on each side of the stalk. The flowers are underneath these leaves, hanging in pairs together. They are like little green bells, and I think unless I had lifted up the spray of leaves I might not have seen them at all.

"The reason it is named Solomon's Seal is because there are scars on its roots which look like marks made with sealing-wax."

"Do you think they look like Solomon's Seals?" Philip asked.

"I'm not exactly sure," I said.

"Then go on."

I told him that Solomon's Seal was not to be picked. " It wouldn't make a pretty bouquet," I said, "although in the woods it looks beautiful."

Philip was sitting, half between a chair and the window-seat. He might have fallen any minute, but he listened to every word.

"Is that all you have to say about it," he asked. I nodded, "yes." 
"Then begin about False Solomon's Seal, and tell just why it's called false."

"That is because its leaves look almost exactly like those of Solomon's Seal," I said, " although the sprays of leaves are much larger, and they have no flowers like bells hanging underneath them. Perhaps they wanted first to be Solomon's Seals and then decided to be something else."

"Have they no flowers, Philip asked.

"Oh, yes," I told him, "beautiful flowers, and much easier to see than Solomon's Seal's little green bells. They have hundreds of tiny, white flowers which grow in a bunch at the end of the spray of leaves. Then they have a very sweet scent. You can find them by that alone when you are in the woods. Grandmother thinks they are very handsome plants and that they should have a name of their own. She calls them 'Wild Spikenard.' "

"It's time to hear about False Lily-of-the-Valley," Philip said.

I thought it must soon be time for luncheon, but I told him quickly, that it was a dear little plant, and that to grow well it snuggled up closely about the trunks of old trees, where the soil was rich and moist. It was much smaller than the other two plants, I said, and stood up quite straight, while they leaned over. I said also that its tiny flowers had the same sweet fragrance as the False Solomon's Seals, and that although they 
were smaller, they grew in bunches at the ends of the stems and had something of the same look. The only reason, I said, I could think of its being called False Lily-of-the-Valley was because its leaves were so much like those of the true Lilyof-the-Valley.

"They're related," Philip said, and he was imitating Tommy again.

"Do you think you could tell these three flowers apart," I asked him.

"Solomon's Seal, little green bells under the leaves," he began, marking it off on his thumb; False Solomon's Seal, bunch of sweet, white flowers at ends of the leaves; False Lily-of-theValley, the dearest, sweetest one of all."

I was going to ask him if he had listened when I told him about the last one, only then we had to go to luncheon.

Philip is very queer sometimes. When we went into the dining-room I saw that he had three of the very flowers we had been talking about in a bowl. He had been out early in the morning with Tommy, and had heard all about them. I said very little to him after that, but he didn't mind because he knows that Grandmother thinks children at the table should be seen and not heard.

When Mrs. Todd talked about their visit to Philip's aunt she never said a word about the six cousins.

After luncheon, when we were out on the lawn, 


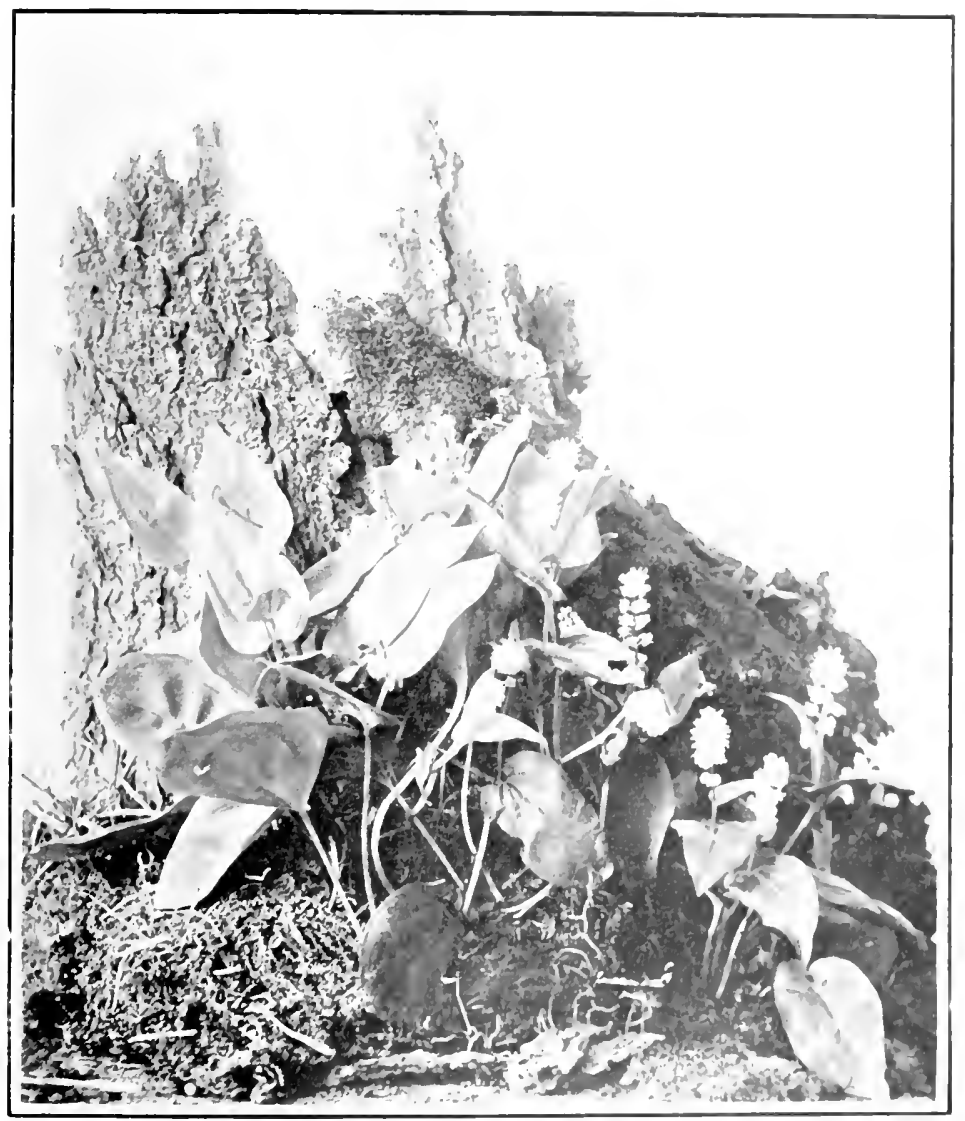

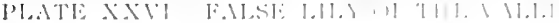




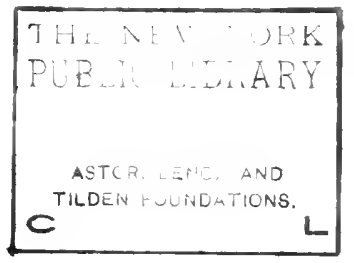


I stayed very close to Mrs. Todd's side, and when she was not talking, I said: "It's strange about Philip's cousins being all the same age. Those six girl cousins," I said, as she didn't seem to understand. Then I gave her arm a little tug, " the six girl cousins he has just been away visiting, the ones he is going to have here."

"My sister has no children," Mrs. Todd said. "I cannot think what our little girl means."

"Who did Philip play with while he was away?" I asked.

"Why six kittens," his mother said. "He sat in the sun playing with them from morning till night."

"They were the cousins then," I whispered to her, for just then Philip and Grandmother caught up with us. 


\section{CHAPTER XVII}

\section{THE FIRST DAY IN JUNE}

JUNE has come; only last night we said good-by to May. It is early in the morning, and I think perhaps it is hardly as warm as it was yesterday. Not a single one of the buds in Grandmother's rose garden have come out especially for to-day. The Roses there that are full blown opened on one of the last May days. In the city, I remember hearing that June was the most perfect month in the country, but I am wondering how it can be more beautiful than May.

I used to think that when June came everything would be changed at once, and that things would be quite different on its first morning from any other morning in the year. I'm sure when I awake Christmas morning that nothing seems at all the same as on other days. But I see now that I must keep my eyes open, as Tommy says, to see why June is more perfect than May.

This morning I have been up to look at Old Adam. A few Rock Pinks are still there, Wild Geraniums are all about, and the True and the False Solomon's Seals are looking just as they did last week. Poor Robin's Plantain has grown a I 06 
little taller, but it looks no more sad because the autumn relatives have not come, nor any more gay because June is here.

I miss Jack-in-the-pulpit. Of course his leaves are still in the woods, but the pulpit and the little preacher have both fallen, and I can see quite plainly that in their places berries are beginning to grow. They are green now and hard and fat, but some day they will turn bright red. I only caught a glimpse of the Star of Bethlehem once this morning. There is very little Columbine left, and although I have never been again to Uncle Hiram's woods, I know the beautiful Yellow Lady's Slipper must be quite faded.

Tommy has gone away for the whole day with his father, and Philip Todd is out setting traps for rabbits. Sometimes he makes a trap with sticks that looks just like a figure four. At its sharp end he fastens an apple, or something that Master Bunny likes to nibble on; only when he runs in to take it off the stick, another piece of the figure four slips out and a box falls down and covers him. Then Philip catches him very easily under the box, and carries him home to live in a hutch. He has said nothing more to Tommy or me about his six cousins since the day Tommy asked him if he liked kittens.

After luncheon I ran out into the meadow, for it was still the first June day. I thought there might be something to see there that did not grow 
about Old Adam. I had not gone very far when I looked down and truly the grass was blooming. I could hardly believe it at first; but then I remembered it was June, and thought it very wise of the grass to know this, and send out such dear little flowers.

They were a deep blue, and the second time I looked, I felt quite sure they belonged to the grass. They were the shape of tiny stars, and in the center of each one I saw a round yellow spot that might have been its eye. Then each little leaf of the flowers ended in a tiny point.

"You've a dear little face," I said to one of them, "and you're peeping out at June."

I picked quite a handful of these flowers, for I wanted Grandmother to see that the grass had really bloomed. But not all the grass in the meadow had flowers. It was only in spots I found them, and in these places there were very many.

As soon as I reached home I put these little blue stars in water. Then I ran to find Grandmother. They already had faded, but I thought the water would make them lift up their heads. When Grandmother came each little blossom was tightly closed and no longer looked pretty.

"I wanted to show you how the grass had blossomed for June," I said, "but the flowers have faded."

"Not faded, child," Grandmother said, " they 
have only gone to sleep. To-morrow, when the sun is bright, they will open again. Their name is Pointed Blue-eyed Grass."

I was glad to know the little flowers would open again, although to-morrow scemed a long way off. I asked Grandmother if they had not come out especially for June, and when she said " no," I was almost as disappointed as when they had closed so tightly.

"I have found them in May," she said, "and in July and August, although it is true that June is their high holiday."

After we had had dinner, and I was thinking that if I had not found the Blue-eyed Grass there would have been no difference between to-day in June and yesterday in May, Tommy's mother sent a man-servent, called Michael, to ask if we had seen little Trudy.

"It was Sunday when she came here last," Grandmother said.

"She has often run away before," Michael told us, "but never at dusk, and to-day Master Tommy isn't home to help us look for her."

"I'll help you," I said, and I went to get my hat.

Little Trudy had slipped away while her nurse was having supper, and Michael remembered she had said something about getting blue flowers for Master Tommy.

"Then she must be in the meadow," I said, 
thinking of Blue-eyed Grass. "It's the only place where there are blue flowers."

We went there first, but it is so even and flat, we could see quickly she was not there. Even the cows had gone home.

"Perhaps she calls Wild Geranium blue flowers," I said, and then it did seem dreadful to think of all the places we should have to look for her.

"Master Tommy could tell just where the blue flowers grow, if he were home," Michael said.

I thought of the Quaker Ladies' field, where once before we had found Little Trudy, and I told Michael we had better go there because perhaps she didn't know they were all dead. It was quite a long way to that meadow, and we asked two strange boys we passed if they had seen Little Trudy. They both shook their heads.

When we had climbed the last fence Michael felt sure she was not in that field, although there were many trees and little hills that she might have hid behind. He thought it very queer I had not taken him to look for Little Trudy where there were large blue flowers. "If Master Tommy were only here," he said again.

"There are no large blue flowers blooming now," I told him.

It was twilight and I saw that butterflies were flying about, and in the grass crickets were chirp- 


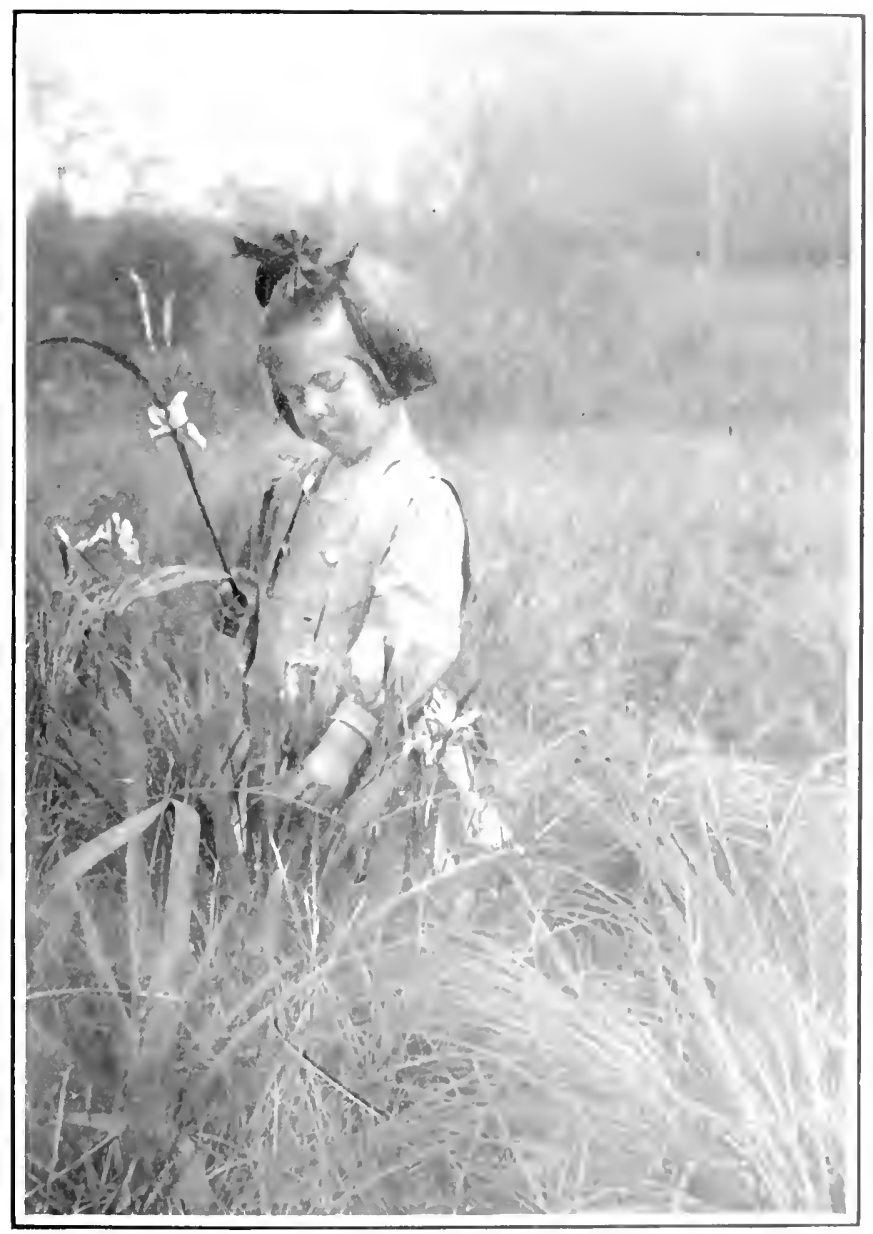

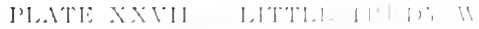




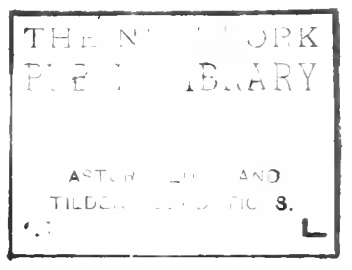


ing, and other insects that I had never seen before cried out with very shrill voices. I heard a treetoad croaking and thought it might rain before we found Little Trudy.

Michael said: "Perhaps she didn't go after blue flowers."

When we came out on the road again he called to a man driving a cart to know if he had seen a little girl anywhere.

"There's one now, down in that 'ere swamp with them blue flowers," the man answered, and pointed the way.

Michael took me up on his shoulder then and carried me, for the field before the swamp is hard and rough for walking.

Little Trudy was in the swamp, but we were there a long time before we found her. Her dress was just the color of the twilight, and if it had not been for her black hair we might not have seen her at all. Everything was still and looked like a mist. She had gone quite away into the swamp, and Michael knew she must be very wet. It was hard to keep on the little hills of grass, and some of them were farther apart than Trudy could jump.

It looked almost as though she had been picking blue flowers. In her hand she held a long stem of something. I could see it was not a Cat-tail, nor one of the long grasses that fill the swamp. But I knew I should have to wait until later to find 
out about it, because now Little Trudy had to be taken home.

Michael picked her up without saying a word, although she talked a great deal to him.

"Trudy never go home," she said, "she too tired. Blue flowers very far. Trudy find them just same."

Michael had a heavy load going back with both Trudy and me on his shoulders. He said he didn't mind, and he walked so fast I asked him if he had on his seven league boots.

Little Trudy's mother was so glad to have her back that she never said a word about how naughty she had been to run away. She just put her to bed.

Grandmother said that was the best place for me too when Michael took me home. I went to sleep, thinking that the next day I would find out from Tommy about those blue flowers.

The first twilight in June had been much more exciting than either the morning, or afternoon. 


\section{CHAPTER XVIII}

\section{LITTLE TRUDY'S BLUE FLOWERS}

It was not because the swamp is far away that Tommy had said nothing about Little Trudy's blue flowers being there in bloom; but because it is out of his way, and he thought it more full of Cat-tails than anything else. When he goes to a swamp he chooses Secret Valley, and there of course it is too dark and slimy for blue flowers to bloom. Now we have all seen the wonderful ones that Trudy carried home that evening.

Their name is Larger Blue Flag. They look to me quite as much purple as blue, and they are something like Irises, only not quite so large. What I think most beautiful about them are the fine, golden lines which run along their three largrest parts. They give the flowers a look that makes me think of kings and queens when they sit on thrones, and their subjects go and kneel before them. Trudy gave me one of her Blue Flags, and I put it in a little vase on the library table. 'The Blue-eyed Grass which is also there has already closed its blossoms for the day.

To-day, the old gentleman who is Grandmother's friend, and a botanist, has come for afternoon tea, but Tommy is not here yet. 


\section{LITTLE TRUDY'S BLUE FLOWERS}

Perhaps I have not said that the name of Grandmother's friend is Professor Bonn. His ancestors lived in Germany, in a university town that has the same name. It is not only because he is a great botanist that so many people know him; I think it must also be because he looks like the pictures of the poet Bryant, the one who wrote beautiful verses about the Yellow Violet. When the professor talks about flowers it is just as though he were telling a story. He saw the Blue Flag on the table before he had his tea, and then he said, for we never have to ask him to "go on ":

"So you know Master Bee's royal road, and the toll he pays for passing over it? He's on his way to court. You remember his dress is black and yellow? It's not cut like a jester's though, with little points and tinkling bells. Master Bee is a politician. He doesn't care to make people laugh as much as he does to get his own way, even if it costs him a trifle. He pays the price, you see, and so he treads the royal road very boldly.

"It's just here," Professor Bonn said, and he pointed with his gold pencil along the deep purple line right through the flower's center. Master Bee's eye is caught by this gray color, even more quickly perhaps than yours or mine. He never wanders from side to side of this road, but treads it to the very end. It's there he finds what he wants. The flower's nectar is there. He sticks his head 


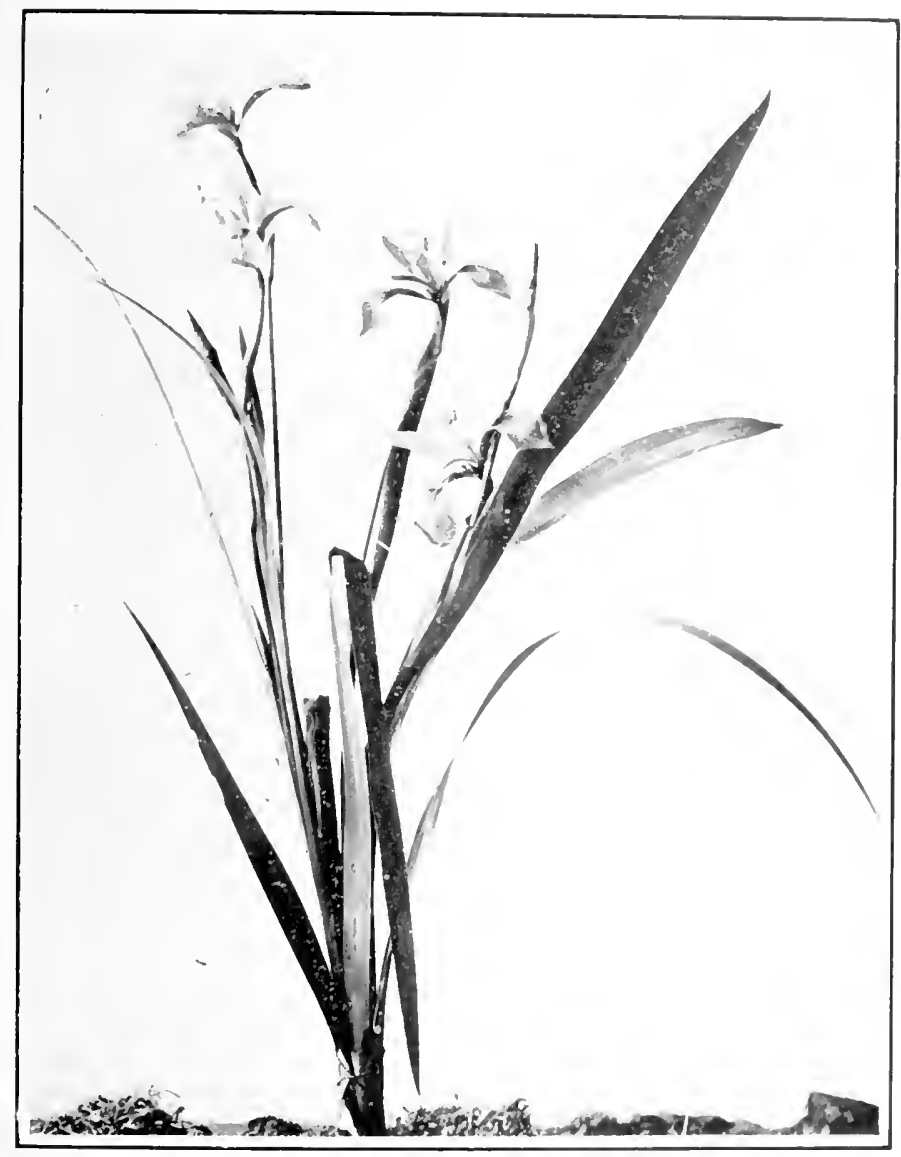

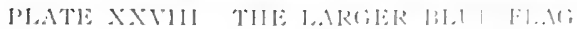



in and sips and sips. This nectar is so sweet and pleasing to the taste that many little boys and girls call it honey. Of course not such wiseacres as you and Tommy, who know, I'm sure, that honey is made by bees and not to be found in flowers."

Tommy had come by this time, and he stood by Professor Bonn's chair.

"When does Master Bee pay the toll," he asked.

"He pays when he is through his meal of sweets. Then he lifts up his head from sipping; but you know he's a big and rather clumsy fellow, and he can't get out without joggling this little piece a bit."

The professor's pencil rested on the parts that hold the golden dust.

"We botanists call these little things anthers," he said, "and it's this golden dust they hold that Master Bee has shaken off on his head when he knocked against them. He pays his toll or his fee by carrying it with him when he returns over the royal road, as an express wagon loaded with yellow dust."

"How does he know where to take it?" I asked.

"He doesn't know," the professor answered. "All he thinks about is going to another flower where there is more nectar for his greedy appetite. But while he is sipping again his body very likely brushes up against this sticky little bit in the very 


\section{LITTLE TRUDY'S BLUE FLOWERS}

center of the flower, we botanists call it the stigma, and not until the golden dust from his back sticks to it, and is taken off can we say his express package is delivered.

"If it were not for Master Bee's carrying this yellow powder and letting it touch these particular spots in other flowers, few seeds would be formed and we should not have nearly so many flowers. And the Blue Flags know very well how to tempt him to visit them. They give him a sweet, luscious feast and it is only polite of him to do something in return for them. Dame Nature besides has given him wings so that he can travel about from flower to flower without even buying a railroad ticket. The flowers, of course, must spend their whole lives in the very same spot. We and the bees can go to see them; they cannot come to us."

Then Tommy told Professor Bonn how his little sister had gone to visit the Larger Blue Flags and how frightened we all had been when thinking she might be lost.

"Little Trudy knew they were blooming in the swamp," Tommy said, "because the milkman brought her a bud one morning, and it had come out in water. No one thought she could walk so far."

Tommy also said that he had scolded her himself, and that she had promised him never to run away again. 


\section{LITTLE TRUDY'S BLUE FLOWERS 117}

It was my turn then to talk with the Professor, and I told him all about finding the grass with little blue blossoms on the first day of June, and that in the twilight I had found Little Trudy with Blue Flags.

"They're related," the professor said, smiling, and I was sorry Philip had not heard that other people besides Tommy said, "they're related."

"Yes, they're members of the same family. One is large and proud and beautiful, and the other is small and bright. So it is with flowers, the same as with people."

"We don't find so many blue flowers as we do other colors," I said, " though when we do, we're always glad."

"You have favorites, then, among the flowers' colors?" the professor asked.

"Mine is pink," I said, " and blue, too, because it's the color of the sky, and no other color is quite so pretty."

Tommy said he liked red and yellow best of all, because they made him think of Columbine.

"And I like white flowers," Grandmother said; "so none of the colors need feel slighted. Each has its stanch admircr."

Then Professor Bonn took another cup of tea and talked a long time with Grandmother about the school that is building in the village. When he was going away he said:

"Madam, may I have the pleasure of dropping 


\section{LITTLE TRUDY'S BLUE FLOWERS}

your letters in the post? I see you have a number ready."

Afterward, when Grandmother and I were alone, I said: "Perhaps people are more like bees than they are like flowers. Professor Bonn comes to drink your tea and eat cake, and when he goes away he carries your letters to the post. It's very much like Master Bee going to sip nectar and taking away the golden dust."

"Matters of courtesy," Grandmother said, and then she laughed. 


\section{CHAPTER XIX}

PROFESSOR BONN'S LETTER TO PIILIP

When Philip Todd heard that Little Trudy had gone to find the blue flowers, and what Professor Bonn had told us about them, he said he would like to hear what the professor knew about another flower that he had found.

"I know its name myself," he said. "It's Milkweed. I've seen Milkweed other years than this; only somehow this one doesn't look quite the same, and then it's out so early. I never had it before in a bouquet with Wild Geraniums and Rock Pinks, and a few sprigs of Columbine. Yet Columbine is lasting late this year."

Grandmother thinks there is no one who watches the wild flowers more and knows their ways better than Philip, when he is in his good moods. The difference between him and Tommy is that Tommy loves all flowers, while Philip only pays attention to those that are rare, or very beautiful; and then he cares for them in a shame-faced way, saying always that animals are twice as interesting. He has even said that when he is a man he will not care for them at all, because then he will be driving racehorses.

I knew it must be a very odd flower that made Philip wish to show it to Professor Bonn; and 
when Grandmother came in we asked her if he were coming soon again. She said she didn't know, but after talking with her a few minutes Philip decided to send the professor a note, and a little pressed piece of the flower. He thought he would write that he knew it was called Milkweed, and then ask if it were just the same as the one that blooms later along the roadsides, and is so much larger and not nearly as pretty.

Philip had found his treasure in Miss Amelia's wood, where it is darker than about Old Adam. He goes there sometimes and stops on the way by rocks like steps, where many beautiful little flowers grow.

"It isn't even in Tommy's books," he said about his Milkweed, and this he thought a very great joke.

Herr Wilhelm Fritz said: "Dat is a milkveed. Dat is a real veed dat America can't say is not her own."

"It is a flower, and pretty," Philip replied, for he was vexed that Herr Wilhelm Fritz had called it a weed.

"Mine son, dat is a veed," Herr Wilhelm Fritz said again, "it's just wun of der three dat dis country has got; der Milkweed, der Ragvort and der Goltenrod. Dis wun is out now, der others vill come soon."

"But there are hundreds and hundreds of weeds here," Philip said, and he waved his arms 


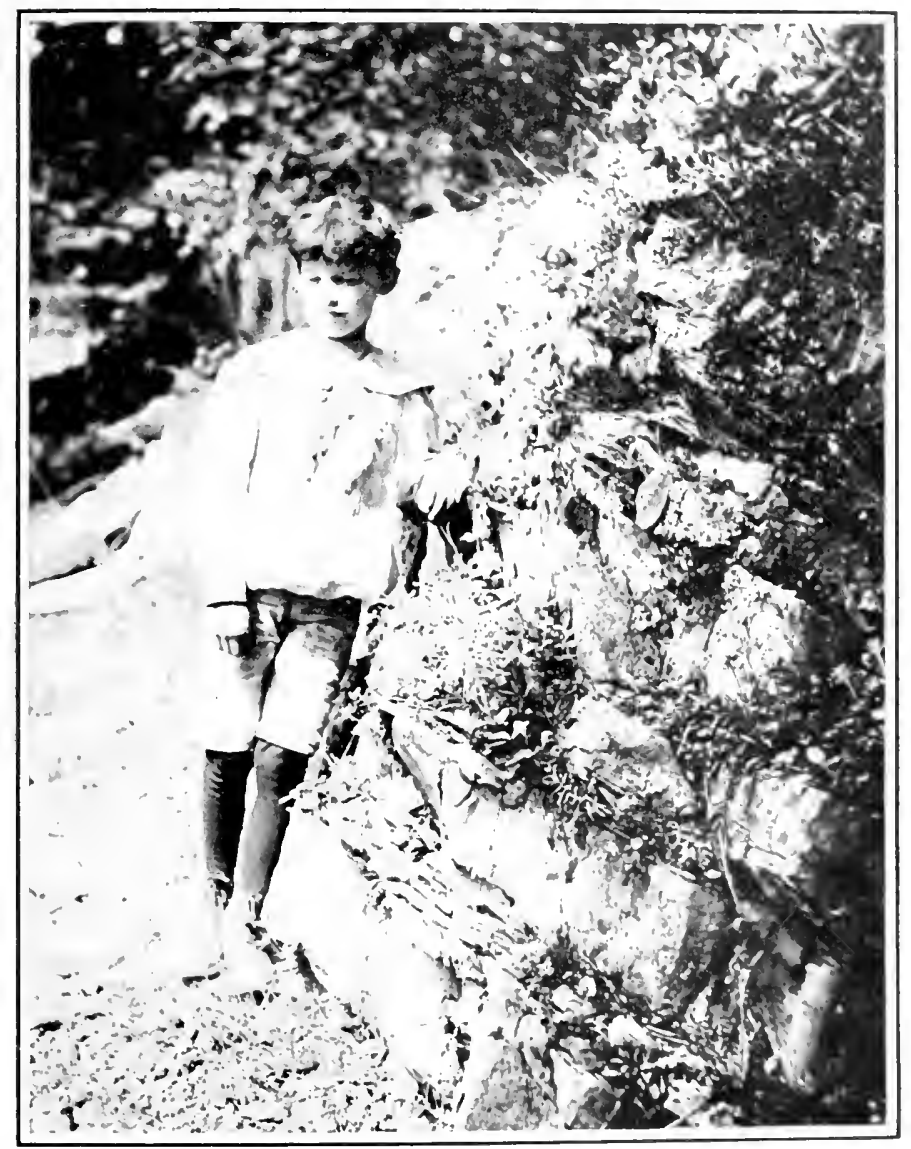

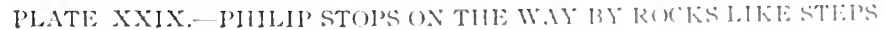




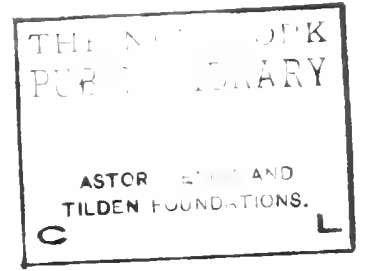


out as though he meant to cover the whole of America.

"And dey hev all come from Europe, mine son. Dey are just as European as Herr Wilhelm Fritz. Der seeds hev come over in der ships, and dey hev even crossed der ocean in der air, dey hev been so anxious to get here. Den dey get treated prutty vell and dey stay. Der is just more of dem here dan Herr Wilhelm Fritz can count. But der Milkveed belongs here, and it is a veed."

It was no use trying to make Herr Wilhelm Fritz believe Milkweeds were flowers when he had called them weeds; but Tommy said he would find out about the European weeds, and what Herr Wilhelm Fritz had meant by saying their seeds had crossed the ocean in the air.

That evening Philip sent his note to Professor Bonn and the very next day he received an answer. The letter was long and written so close and fine that Grandmother had to read it to us. This is what it said:

"My Dear Philip :

"Let me congratulate you because you have found the early Milkweed, and because your cyes are sharp. I presume you wore no glasses when you noticed that it was different from the common Milkweed, which we will not see bobbing its heary head of pale pink blossoms along the roadside fences until June is farther on its way. 
"The Milkweed which you found is shy and fragile. It grows in stony woods, and never in great company. A few of them are gay together, and sometimes one might tramp a good half day without finding them at all.

"You saw how daintily it lifts itself above the green things about? Yet it never grows very tall, perhaps not more than two or three feet. No doubt you were charmed by the purplish pink of its blossoms. They make me think of the inside color of seaside shells. Then you were pleased with its leaves, since they are so long and pointed, and group themselves around the middle of the stem in little companies of four. In fact, my dear Philip, you were looking at the one of the family which we old and sedate botanists call Four-leaved Silkweed, even though, as you and I have already decided, it is a Milkweed.

"Look at the small flowers forming the bunches, for they are fashioned in the same way as those of each member of this great family. Knowing one well you have but to say when you meet another: 'Ah, here is a Milkweed friend. It is not the woodland sylph, no, nor the roadside plebeian. There is then some particular thing for me to notice, either in the color of the blossom, the way its leaves grow on the stem, its roughness or smoothness, or its either having or lacking a milkwhite sap.'

"Each Milkweed flower, my dear Philip, is 


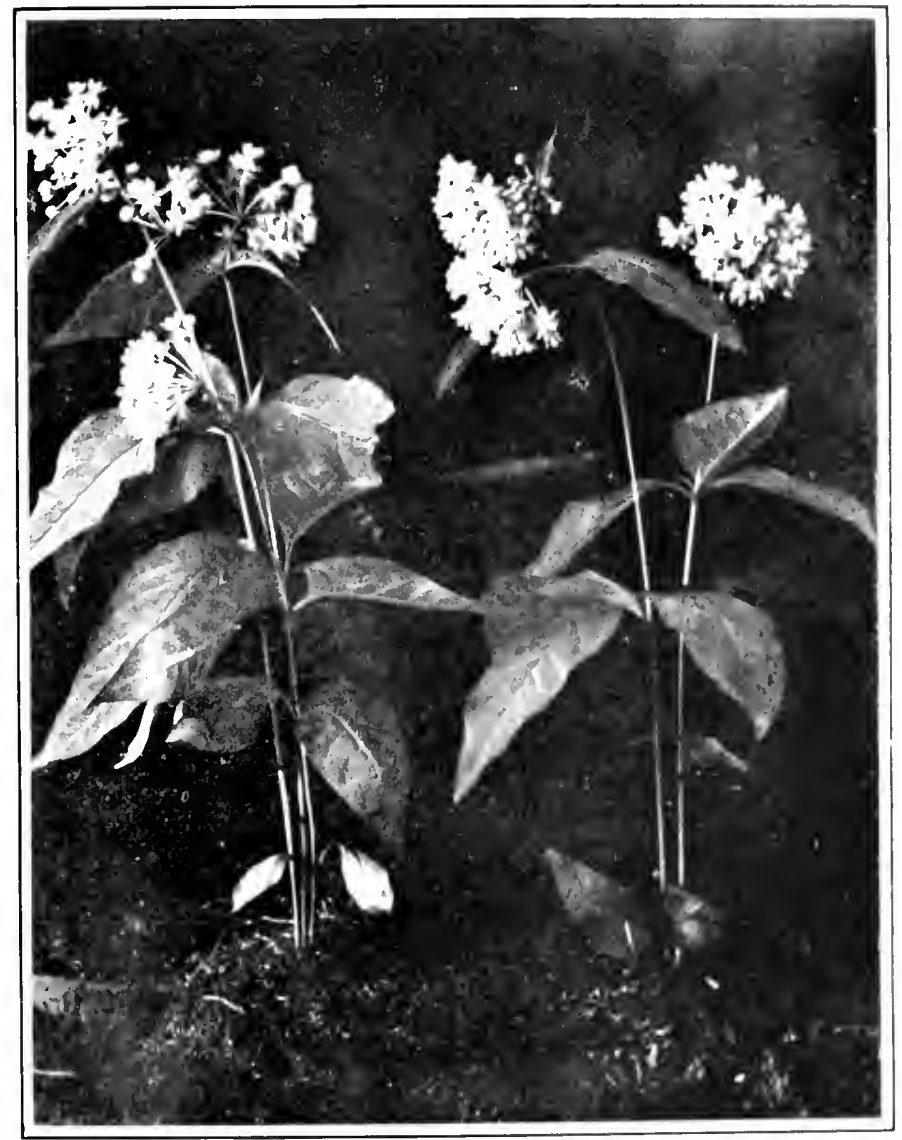

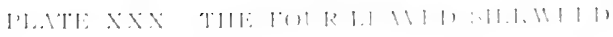




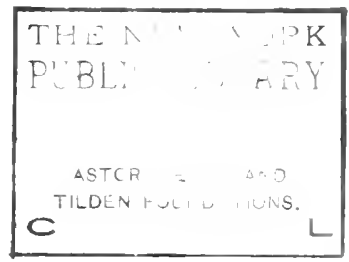




\section{PROFESSOR BONN'S LETTER 1:3}

as marvelously made as a king's palace. Five of the flower's little parts are turned downward. In that position they could hold no nectar for Master Bee's entertainment. Still the flower has five tiny hood-like pieces wherein the nectar is secreted. The insects find them easily; try if you can do so as well. Besides, the golden dust is not scattered loosely. It is compactly packed in two little masses that are held together by the finest thread imaginable. These are golden packages ready for the express. When Master Bec comes along for his feast of nectar, his feet somchow get entangled in this tiny thread. He is a poor one at picking out knots, and so he carries off the packages and leaves them at the next Milkweed house he visits. Most likely they are caught there by that little sticky spot called the stigma. Then, after a time of waiting and growing, two long pods are formed like those you have so often seen along the roadside.

"Lose your chagrin that Herr Wilhelm Fritz. has called your pretty plant a weed. At least it is a right royal one, and a true American. But can Herr Wilhelm Fritz always tell a weed from a flower?

"Some say a weed is one that covers up and monopolizes waste ground. This your woodland Milkweed does not do. I would I might saly the same of Wild Rose. Another says a weed is troublesome and difficult to get rid of. I cannot 


\section{PROFESSOR BONN'S LETTER}

believe it of your flower, but it is true of Wild Morning Glory. Call your Four-leaved Silkweed flower or weed, neither name can change its beauty.

"When autumn comes shall we take the narrow path to the village together? We may then meet the very weeds whose seeds have so gallantly crossed the ocean in the air. Indeed they might give a few points to the builders of air-ships.

"Believe me, my dear Philip, with best wishes for your botanical success,

"Your Friend,

\section{"Stephen Bonn."}

Philip was so delighted with his letter that he said he would keep it in his scrap-book and read it over and over again until he knew it by heart. Grandmother has loaned him her finest magnifying-glass, and he has several of the little Milkweed blossoms under it. Although they are so small, he says, there is a lot more to understand about them than there is about Blue Flag.

Grandmother told him that if he didn't learn it all this year he might next year, or the next, and that Professor Bonn's letter would keep a long time. 


\section{CHAPTER XX}

\section{ON WILD ROSE'S HIGHWAY}

Wild Rose's Highway is the little path that leads to the village. We like to go along it, because that way is shorter than around by the road. On both sides of the lane now Wild Rose is blooming, and Tommy thinks it is the prettiest rose in the world. It has only five very thin, pink petals. They are never white, or red, or yellow, but always a bright, pure pink. Besides, Wild Rose doesn't like being taken from the highway, and fades almost at once, although even then its sweet scent is left.

Wild Rose has what the most beautiful of Herr Wilhelm Fritz's roses has not, and that is a circle in its center of many soft little things bearing the golden dust. Wild Rose has something to do in life, which is to make seeds and sow them, so that year after year there will be roses along the highway.

Now the garden roses gave up taking this trouble long ago, and are very idle. They seldom make seeds, for Herr Wilhelm Fritz looks after there being plenty of roses each year. Of course he doesn't make seeds for them and sow them; 
but he has a way of coaxing several roses to grow from little shoots, or clippings that he takes from one rose. He told me himself that since roses had been helped along by gardeners they had lost nearly all the little yellow things from their centers, and now are nothing but petals, which all look alike.

The leaves of Wild Rose remind me of other rose leaves. I mean that they have leaflets growing on each side of the stem, and that one leaflet alone makes a point at the end. About the edges they are cut as though they were fine little saws.

I'm glad Tommy loves Wild Rose better than the ones that grow in the garden. He didn't tell me so, still I know it quite well. This is the way I found it out:

One day Grandmother and I were going along the highway, and just as we came near the place where Wild Rose is very beautiful, and Wild Strawberries are already ripe, we heard a voice, although we could see no one. We waited a minute. It was not a bird, we knew, but just as we stood quite still to listen it stopped, and a locust began singing.

"I've told you this before, Rosie dear," we heard the voice say. Then the locust sang very loudly, and it was some time before the voice called out :

"Next to Columbine, you're my favorite flower." 


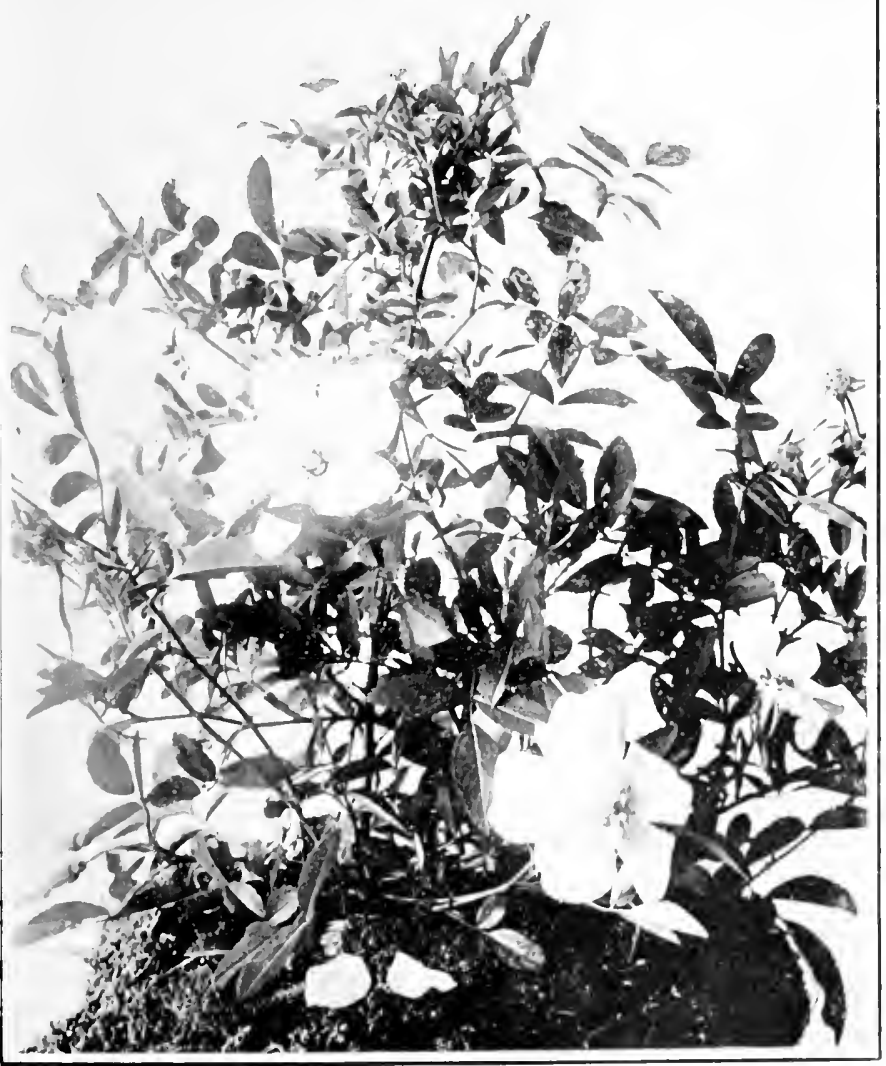

ILATE XXXI, WII, R(Bil: 


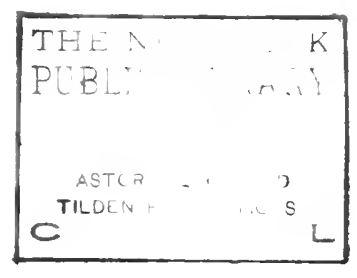




\section{ON WILD ROSE'S HIGHWAY $12 \tau$}

It came from the side of the path where we could not see the top of the bank. A cricket began chirping as though he really were angry. We couldn't hear a single word then. The wind also blew and stirred up the leaves until they made a great noise. There was a black cloud in the sky, rolling and tumbling over the soft white ones and the blue sky underneath.

"Will it rain?" I whispered to Grandmother, for I was hoping we might stay where we were to hear if the voice would say something more. She shook her head: "A wind cloud, child."

Then when the leaves were a little quiet, the voice said, quite loudly:

"You're different from Columbine." It was very provoking, but just then the locust broke in. I thought he never would stop singing.

"You're very-" but for the locust we might have heard what else the voice said.

The wind had also begun again. It blew so loud and strong that I had to hold my hat on with both hands. Somewhere, quite far off, we heard a dog barking. For a long time the voice seemed still. Then it began again:

"It's a shame to call you a weed."

Grandmother looked at me with a little smile. We were almost sure the voice was Tommy's, and that it said something else, but we couldn't hear, for a tree-toad made a noise big cnough for the bullfrog in the stream. A robin, too, hopped out 
in the path and chirped and chirped. His note is always loud and bold, and at that minute we could hear nothing else.

"There are very many noises to-day, aren't there?" I whispered to Grandmother.

"It only seems so," she whispered back, "because we want to hear the voice."

"These thorns are your body-guard, Rosie."

Then Grandmother whispered to me that it was true they kept insects from crawling up its stem and stealing the golden dust; and that cows couldn't eat its pretty leaves on account of the thorns.

After a while the wind and the tree-toad grew more still, although then the cricket began his chirp. I picked up a little pebble and threw it where I thought he might be, and after that he was as quiet as a mouse. This time we heard the voice plainly:

"You have no one to do you up in straw when winter comes, as Herr Wilhelm Fritz does the garden rose bushes."

Grandmother smiled at me again, for this time we were sure the voice was Tommy's and that he was talking to Wild Rose.

Then the cricket forgot about the pebble I had thrown, and cried out, in a voice shriller than ever.

"Dear me," Grandmother whispered, "that cricket is most persistent." 


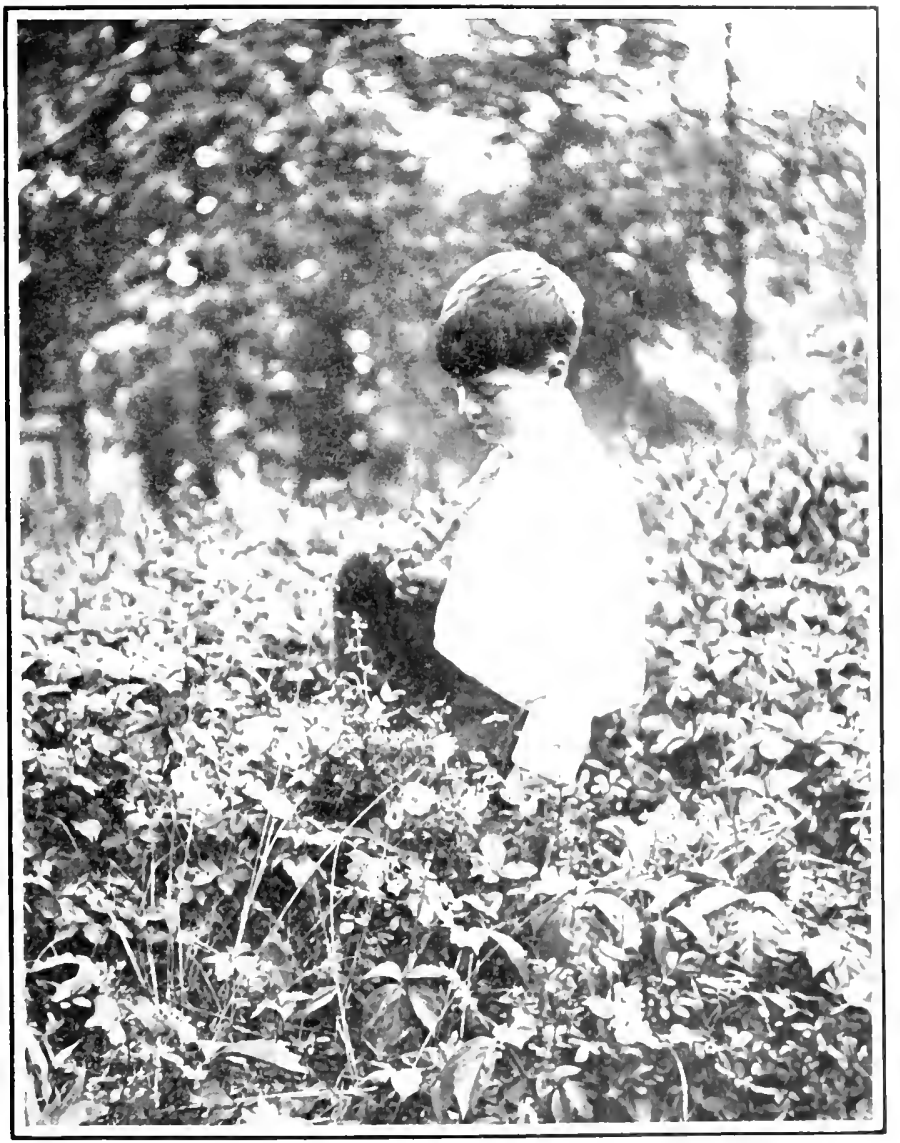

PLATE XXXI1. TALKING TO WIL, R(SE 


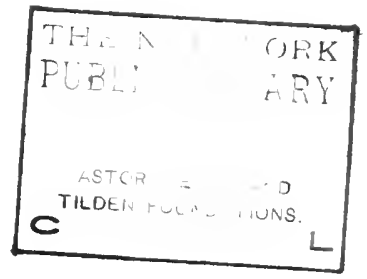


"What does it want?" I asked her, and I threw another pebble.

"I believe it's trying to hum," Grandmother answered, "just hear it!"

At the same time the locust sang, the cricket kept right on, the robin crossed the path, crying "chirp" and the wind grew louder.

"Let us go now," Grandmother whispered. "I think Tommy has nearly finished his talk with Wild Rose, and after all there may be some rain in those dark clouds."

Just then a drop struck my face, so I took Grandmother's hand and we went on to the village very quickly. It was only a shower, and the sun soon chased it away; but I could not help wondering what Tommy had done when it was coming down so hard.

Grandmother said: "Rain doesn't hurt boys, nor will it harm Wild Rose. It will make her lift up her head higher, and her leaves will glisten, after the dust has been washed away. But it takes the starch out of my little girl's frock, and her pretty curls are growing shorter. The shower isn't half as fine for her as it is for Wild Rose.

We went to see a lady Grandmother knew in the village, and then when it had cleared we took the road home. It was still too wet for walking along the highway. When we came to our house Tommy was sitting on the veranda, rocking himself in the largest chair of all. 
"We heard a voice along Wild Rose's Highway, talking to the queen herself," Grandmother told him.

"It might have been the cricket," he replied.

"The cricket is not so fond of Wild Rose as the voice we heard."

"The locust was singing," Tommy said.

"It was to the warm weather," Grandmother reminded him.

"I heard the robin chirping," Tommy hinted.

"He was calling his mate," Grandmother said. "The tree-toad was pretty chatty," Tommy said.

"It was about the storm," Grandmother told him, " only the voice I mean had something about it most familiar to my little girl and me."

- "Then it was my own," said Tommy, and he made Grandmother a bow, "for I was on the highway talking to Wild Rose." 


\section{CHAPTER XXI}

PHILIP GOES FOR A BOUQUET OF MEADOW-SWEET

To-DAY is the Ioth of June, and one of the loveliest wild flowers in bloom is called Meadowsweet. Every year that Tommy can remember it has lasted until midsummer; although he thinks it prettier now than later, when its leaves will be covered with dust, and its flowers will look dull and faded. It is often called Pride-of-the-meadow, and Queen-of-the-meadow, and perhaps it has other names besides these that I do not know. It looks like a queen in Grandmother's field. There it grows in the middle, and all around the sides, and especially in places where the soil is moist. I think it also likes to lean against the stone wall. I have seen it along the road, and on Wild Rose's Highway, and in another place I know, it is all twined about with Blackberry vines. It has never come out yet by Old Adam.

Meadow-sweet is not simply one stalk that comes up alone and bears a large flower; it is a small bush, or shrub, something the shape of Wild Azalea. The flowers are no larger than my little finger-nail; but so many of them are packed together in pointed bunches that, from a distance, they look like one large flower. They are pink, 


\section{A BOUQUET OF MEADOW-SWEET}

and white, and each one has five round petals the same shape as those of Wild Rose. Ever so many yellow pieces stick out from their centers and give the bunches a soft, fluffy look. The green leaves on the bush grow one above the other, and have little notches around their edges. The stems are wine-colored.

Philip always coughs and laughs when Tommy says that Meadow-sweet and Wild Rose are related; but Herr Wilhelm Fritz knows this is quite true. I used to be sorry that Meadow-sweet hadn't such a sweet scent as Wild Rose. But only a few wild flowers have any fragrance; and Tommy's father says we should be more grateful when they have it, than sorry when they have not.

After luncheon to-day Philip started out to get a bouquet of Meadow-sweet for his mother. $\mathrm{He}$ went to Grandmother's field, because the largest one of all these bushes grows there by the wall. It is so tall and strong that a pair of robins built their nest in it this year, instead of in the Elderberry bushes on the other side. And robins' nests are heavier than those of most birds, because they make them with mud as well as straw and tiny twigs. Both Tommy and Philip call this bush " the Veteran."

Philip picked his bouquet from an old part of the bush where the branches were close together. If he had broken off its young shoots it would have made "the Veteran" look wounded. 


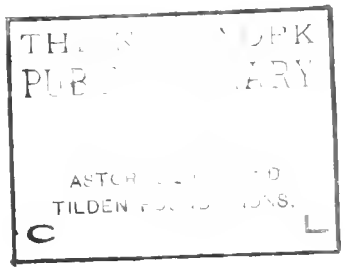




\section{A BOUQUET OF MEADOW-SWEET 133}

As he picked the flowers a darning-needle darted about his head, went away, and then came back again. Philip didn't mind this in the least, although whenever it came too close to him he brushed it away with his little white cap. There didn't seem to be much to do just then, so he walked slowly toward home. The sun was very hot in the meadow, and to keep it from fading the flowers he held them under his cap. Philip was tired, and when he came to a tree by the last fence he sat down under it to rest. Soon he laid his head on the soft grass, and before he could think of anything he was sound asleep.

He dreamed that he was somewhere in New England, and that he saw Francis quite as plainly as he had ever done when he was awake. Francis stood beside a Rhododendron bush, and he was shaking hands with a very little man. Philip knew the bush was a Rhododendron because it looked exactly like those the gardener had planted at Warley Towers, and which should bear beautiful bunches of lavender flowers in July. But there were no flowers on the bush Philip dreamed about; there were only large, shiny buds.

The little man was one of the funniest creatures in the whole world. He was no taller than the Rhododendron bush and he had a tiny cap on his head that looked like a box. Half of his clothes was red and the other half was white, while the buttons down the front and those on his shoes were 


\section{A BOUQUET OF MEADOW-SWEET}

round like balls. But it was the little man's face more than his clothes that appeared so funny.

Francis looked down at him and said, in a way that sounded something like a song:

When gentlemen meet there are certain things,

They always do together:

They nod their heads, and shake their hands, And talk about the weather.

The little man never nodded at all. He looked up in Francis's face, and although his mouth was open, he said nothing about the weather. Francis didn't seem surprised because the little man hadn't answered him. He said he was glad to see him standing up so straight, and that he hoped his cap would stay on.

Then a mosquito lit on the end of his funny nose, but he never even put up his hand to brush it away. Things certainly seemed very odd in Philip's dream, and all because the little man neither moved nor spoke, and the Rhododendron bush had no flowers. The little man's ears were large and round, and they stuck out very far as Francis leaned down and said, in the way that sounded again as if he were singing:

When gentlemen part where roads separate,

In noon-day sun, or in rain;

They turn their backs, and say farewell,

And hope to meet again. 


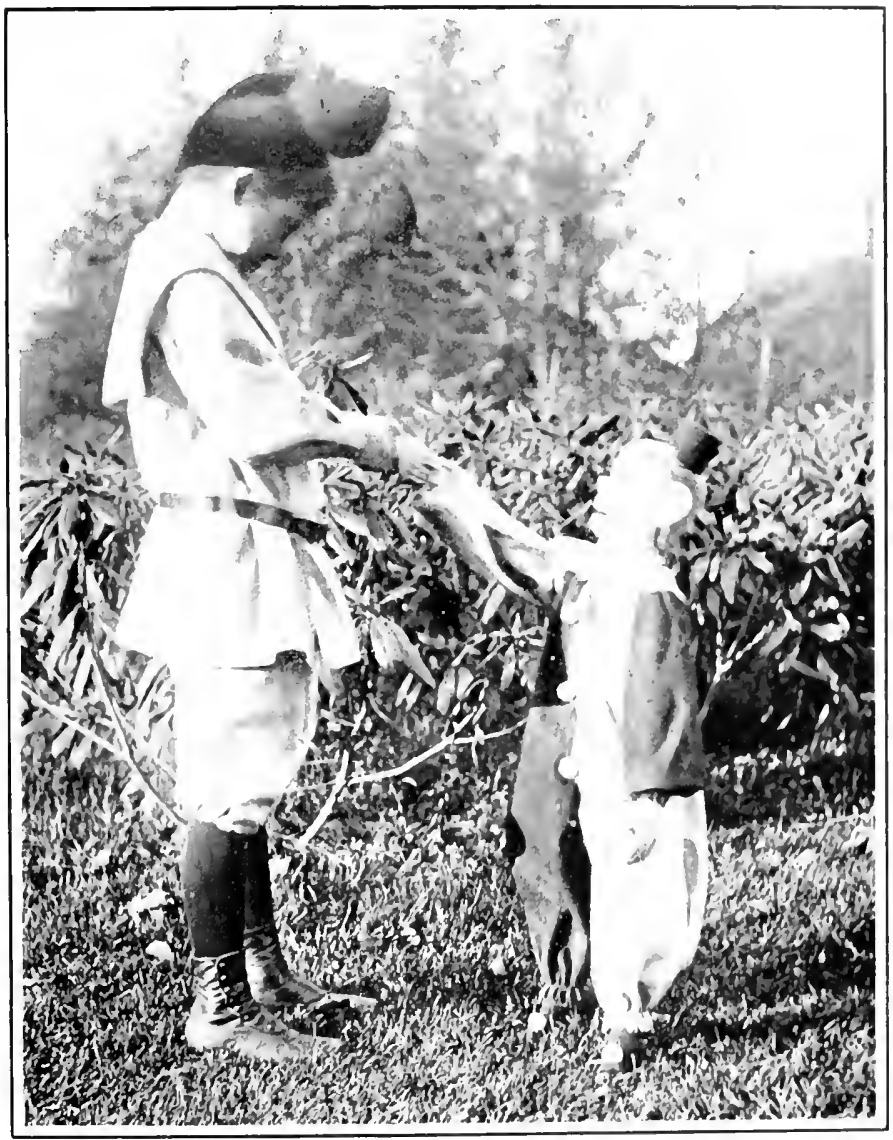

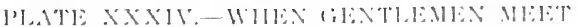




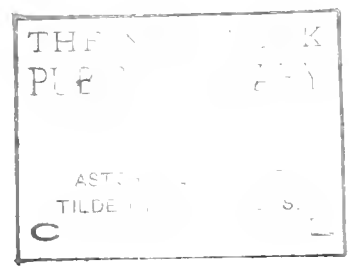




\section{A BOUQUET OF MEADOW-SWEET 105}

Before Francis had said the last word, and before either he or the little man had turned his back, Philip gave a yawn and drew his hand across his eyes. Then he looked straight in front of him, and around on every side. He sary neither Francis nor the little man. There was no Rhododendron bush, and he was not in New England, but in Grandmother's field where Meadowsweet was blooming. Philip jumped up from the ground and stretched himself until he felt wide awake again. Then he climbed over the fence quickly and walked toward Warley Towers.

When he was near the house, he saw a little American flag hanging out one of the windows. Mrs. Todd always puts it there when she wishes Philip to hasten home. He ran in at once and found Tommy and me waiting for him to go with us after Meadow-sweet.

"I've just been down to "the Vetcran,'" he said.

"Then where is the bouquet you promised me?" his mother asked.

Philip remembered that he had left it by the wall where he had fallen asleep, and that his little white cap was over it. We went back with him to get it, for the sun was no longer hot, and on the way he told us what he had dreamed about Francis and the funny little man.

"If that was a true dream," I said, " and the little man was no taller than the Rhododendron 
bush, I'm sure he was the clown your mother sent Francis on his birthday. His clothes were half red and half white, and, of course, he could never brush a mosquito away that lit on his nose."

Then Philip reminded us that his mother was going to take him to visit Francis in New England as soon as the autumn came, and that he would be able to find out if Francis had really played with the little clown by a Rhododendron bush, and also the reason why he had been teaching him the way gentlemen meet and the way they part. 


\section{CHAPTER XXII}

\section{WHEN BERRIES ARE RIPE}

Almost ever since we came to live in the country Tommy has been telling me how fine things would be as soon as Wild Strawberries were ripe. Even Peter pricks up his ears about Wild Strawberries, for he loves to eat them, and smells out where they are, by slipping his long nose through the grass.

One day along Wild Rose Highway the strawberries all turned red. Before this they had been growing and growing, but whenever I looked at them they were green and hard. They turned red so quickly that I thought it must have been in the night, until I remembered that the warm sunshine was their real friend, and helped them to grow soft and sweet.

When Grandmother and I heard Tommy talking to Wild Rose on the highway, we saw many green strawberries with little red patches on them, and we found two that were quite red. But these were not enough to give me a real taste of Wild Strawberries, for they are much smaller than the ones in Grandmother's garden. It has been a long wait for them; perhaps because so many other things had to happen first. 
When we used to go for Violets we passed little white strawberry blossoms in the grass. We never picked them, and I remember, too, that close by them and hugging the ground were ever so many little yellow blossoms. They looked something like Buttercups, only their leaves were more like strawberry leaves. When I asked Tommy if they were yellow strawberry blossoms, he said their names were Five-fingers, or Common Cinquefoils. I thought this a queer name to give the pretty little yellow flowers until Tommy showed me that the leaves were divided into five pieces, something like fingers when they are short and fat.

Each year this little Common Cinquefoil spreads itself by making new plants at the ends of runners, and the Wild Strawberry makes its new plants grow in the same way. Perhaps they both think this is a better plan to keep themselves from vanishing than by making and sowing seeds.

Even though Wild Strawberry blossoms are gone, the pretty little Five-fingers have stayed in bloom; and I have learned to know one of their relatives, which grows quite high and has a shrubby look. Its round, yellow flowers, and the five-fingered leaves made me think at once of the little common one, although they grew on such a large plant.

I remember now that Strawberry blossoms 
lasted only a short time. Perhaps because they wanted their berries to get ripe. They were gone before Violets, and while the berries were growing Wild Raspberries and Blackberries had their blossoms.

Blackberry blossoms were all white, and quite large. They don't grow on little plants like Strawberries, but on prickly vines that run along the tops of fences, or twine themselves in and out among the grass; or else they grow by the roadside, and stand up quite straight. Tommy says the ones that do this are different kinds of Blackberries, although they look almost the same to me as the ones that are vines.

The Wild Raspberry's blossom is the prettiest and largest of all. It looks almost exactly like Wild Rose, only its pink is more purplish, and it hasn't the same kind of sweet scent. It grows on a bush and the leaves are large and something the shape of a Maple-tree's leaves. The fruit is not ripe yet, but Tommy knows that it tastes almost the same as garden Raspberries, only a little more spicy. He thinks I will like Wild Raspberries very much. "They look," he says, "like little thimbles. Some people even call them Thimble Berries."

Tommy thinks it's the greatest joke that many city people believe Wild Raspberries are poisonous. He laughs and laughs over this, and says it's lucky they leave them for those who know better. 
Tommy doesn't laugh so much as Philip, but when he does he nearly closes his eyes and puts his head back and laughs so heartily that every one else laughs too.

Another thing about the Wild Raspberry bush is that its leaves are very useful. Sometimes when we are thirsty, and the day is hot, we fold them together like little scoops and drink the cooling water of the stream from them. When Tommy takes up a little plant to carry home and put in his garden, he wraps its roots around with Wild Raspberry leaves so as to keep them all right. Sometimes, though, he is not near Wild Raspberry bushes when he wants large leaves and then he has to be satisfied with others which are scarcely as useful. I'm sorry that we don't find them near Old Adam as we do Wild Strawberries and Blackberry vines.

Sometimes when Tommy goes to his tree seat to rest and think about things, he finds little Black Caps as well as Blackberry vines growing up all around him. He eats a great many of the little Black Caps, perhaps because they help him to think better.

Until I came to live in the country, I used to think that all berries grew on the same kind of bush; but now it would make me laugh to see Wild Strawberries hanging from Blackberry vines, or Blackberries growing on the Strawberry's little plants. The Raspberry, too, must surely look 


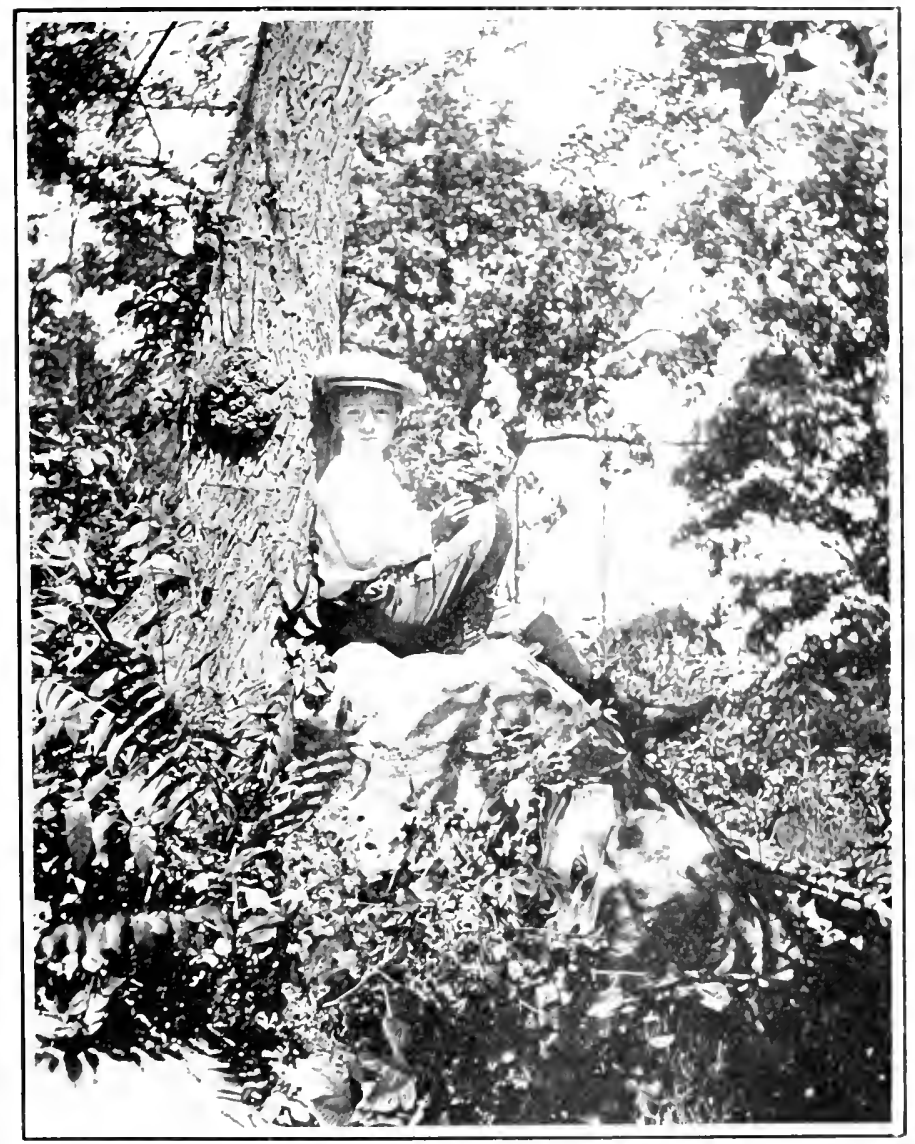

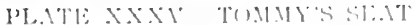




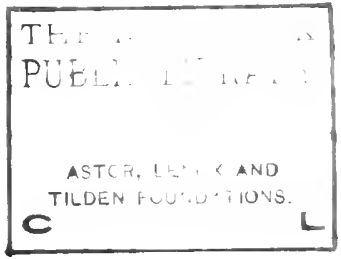


prettiest on its own bush, with its pink blossoms and large, beautiful leaves.

I think I shall always like the taste of Wild Strawberries better than any other fruit, unless I take a great fancy to Wild Raspberries. Tommy knows the taste of nearly all the berries and leaves. $\mathrm{He}$ is always nibbling on something in the woods, because he knows just what is good to eat and what is poisonous. Grandmother thinks, though, it would be very dangerous for a little city girl to eat anything in the woods, for some time a mistake might be made, and there are many plants poisonous enough to kill people.

When I grow older and study about the different parts of plants, the way that real botanists do, I may be able to tell all the members and cousins of the Rose family, even though I may never have seen them before. Tommy can almost do this now, and I think it is because he counts the flowers' five leaves or petals, and notices all the little yellow things in their middles.

I had almost forgotten to tell about the day I ate more Wild Strawberries than Tommy. It was up near Wild Rose's Highway.

The rule we have when hunting for anything is that when it is found it belongs to the one who sees it first; and no one can go where it is until after the one that finds it has left. Sometimes we hunt for Four-leaved Clover. Then if. 
Tommy finds one, I must not go and hunt in his clump for another while he is there. I must try to find one of my own somewhere else. It is just the same with Wild Strawberries.

The afternoon Tommy and I went up to the highway, we were going toward Philip's house to see his new dog. It was early in the afternoon. Suddenly we saw ever so many red spots peeping through the grass. At the place I found first the ground was covered with Strawberries. Every time Tommy looked toward me I was eating them as fast as ever I could. There were not so many where he was searching, but of course he couldn't come over to the patch I'd found, because that would be against our rule.

Tommy called to me not to soil my frock, but I didn't leave my place for that; I went on picking and eating. It must have been a very sunny spot where I was, for nearly every berry there was ripe, while where Tommy was looking they werc just beginning to turn red. I saw that he was finding and eating hardly any.

Then we made a bargain. Tommy was to come over to my patch if he would pick the Strawberries and give me half. He said he would and that he'd feed them to me besides. I sat down on a little slanting place where Blackberry vines were crawling all over, and as soon as Tommy had picked a handful from my patch he came and sat down too. First he ate one, then he gave me 


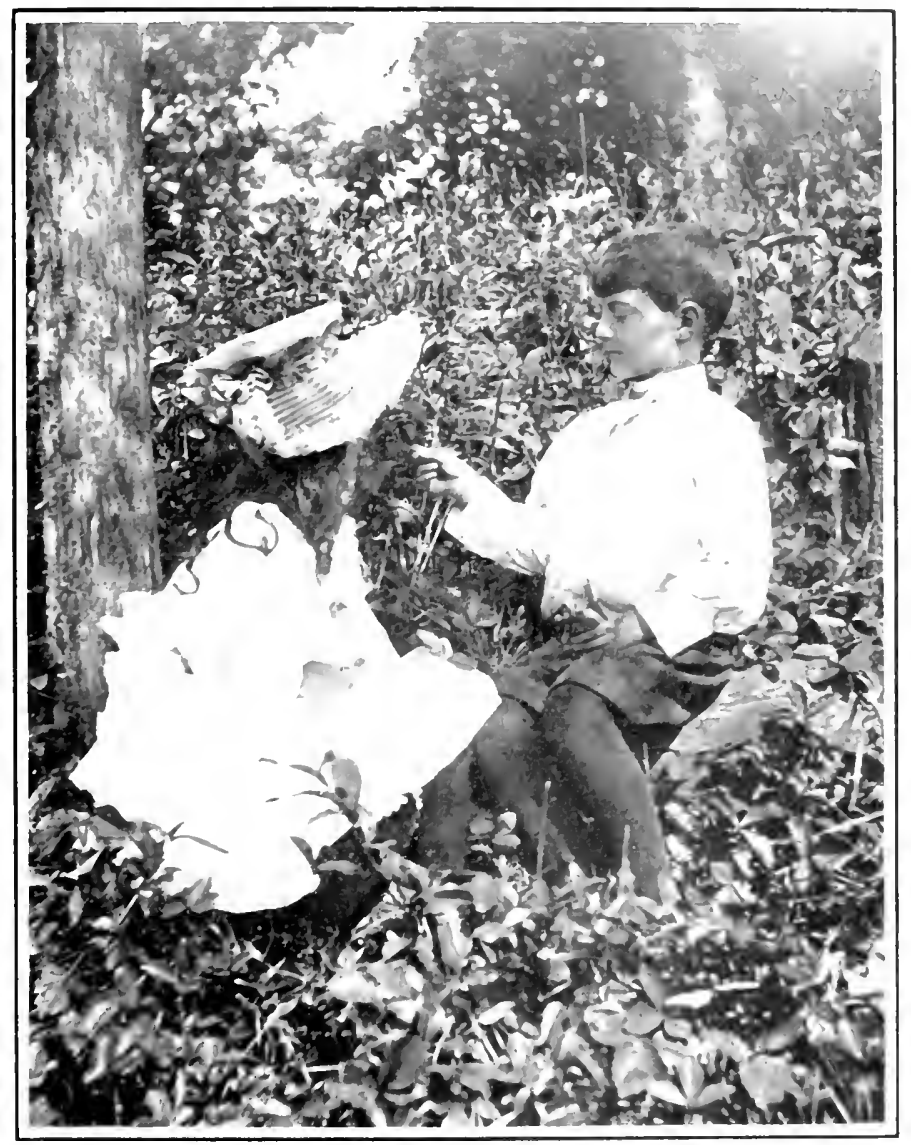

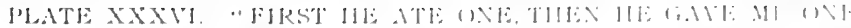




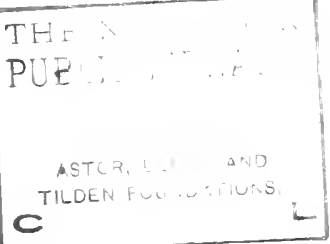




\section{WHEN BERRIES ARE RIPE}

one, and it was wonderful how soon his hand was empty. We didn't eat them every minute because we laughed sometimes, and Tommy said I looked like a baby bird opening its mouth to be fed. I don't believe he meant a young robin, for the ones he showed me when spring was here were the ugliest little things I ever saw.

Our fingers were red to the knuckles when we reached Warley Towers. Mrs. Todd said not to mind though, and that if she had had a chance to eat anything half as good as Wild Strawberries, her fingers would look just the same.

Philip had played so much with his new dog that he didn't even know that Strawberries were ripe. 


\section{CHAPTER XXIII}

\section{LETTERS FROM FRANCIS AND SALIIE}

Another letter and a box has come from Francis. This time the letter was not to Grandmother, nor to Tommy. It was to me. Sallie has written me a long letter too, so we know now what Francis is doing, and all about Sallie's "intentions."

Francis is not going to be an artist after all. $\mathrm{He}$ would rather be a forester. This is not because he thinks it would be fun to chop trees down, but because they are so strong and useful and just as beautiful as the flowers. He thinks every one should know how to care for trees, and when they should be cut down and others planted to take their places. He is already studying about each one and learning how to tell it from its neighbors, and why it is useful.

Francis wrote besides that flowers were blooming everywhere in New England, but that the best of all were the Laurel and the Pitcher-plants. He found out that neither of them grew near our home, and that was the reason he sent us one of each in the box.

They were not much faded, although they had come so far by the post, for Francis had packed 
them himself in moistened cotton. I took them out of the box very carefully. The Laurel looked very much like Tommy's pictures. Francis's letter read:

"The piece of Laurel I have sent is not the large one that some people call Mountain Laurel, or Calico Bush, because they think it looks like that stiff, white stuff spotted with pink. It is the little one which we call here Sheep Laurel, or Lambkill. I love it best, although the larger one is very beautiful, much more so than any calico you ever saw.

"Lambkill is my favorite because it's so pink, and because when thousands of its blossoms are open, it makes the hillsides look like great bouquets. It is not fragrant like the Mountain Laurel, and this makes me wonder at liking it better. Besides, it is poisonous.

" Last spring two of Betsy Tibbit's cows died because they ate its young shoots just as they were beginning to turn green. One day I told Betsy that I thought her cows looked stupid. They always do when I get close to them and see them chewing their cud. She said her cows were as clever as boys any day, and it was just after that they ate the Lambkill. It's too bad the cows have died because Betsy's an old woman, and only has the money she makes from selling milk and butter. "Perhaps you'll think Lambkill is just a little pink flower when you take it from the box. It is a trap besides, and much more finely made than 
the figure fours that Philip Todd sets for rabbits. It isn't really so much a trap for Master Bee as it is a surprise. It doesn't catch him; but it makes him do something that he knows nothing about. This is carrying the golden dust.

"You will see that the ten little things in the flower's center don't stand up straight as they do in most flowers. They are curved over and held down by little holes like pockets in each of the flower's leaves. The golden dust is at their ends. Master Bee is a pretty heavy fellow to tread on such delicate little places, and as soon as he lights on a flower he gives it such a joggle that one or more of the little pieces spring up and scatter the golden dust all over him. It is so light though that he doesn't mind carrying it, and perhaps the very next flower he visits will take some of it off his back. In the middle of each Laurel flower there is the same little sticky place that you have heard about in other flowers, and which is as eager to get the golden dust as the little places held down in the pouches are anxious to be rid of it. Sometimes I wonder if the bees know anything about the help they are to one flower in getting rid of the golden dust, and to another in placing it on the very spot where it will help make seeds. I never used to think bees much brighter looking than Betsy Tibbit's cows."

After I had read all that Francis wrote about Lambkill's surprise trap I took a little pin and 
played bee. It was the stamens that Francis meant were curved over. I tapped one very gently with the pin. It sprang up at once, and a tiny cloud of golden dust was scattered over my finger. I felt so sorry then not to fly off with it to another flower. I began to think Master Bee had a very jolly life.

Grandmother was just as delighted as I with this little surprise trap and we played bee until we had used up nearly all the stamens in the flowers that Francis had sent. The few we left down were for Tommy to see when he came.

After that evening Tommy's father wrote a long letter to Francis, telling him that the Laurel was one of the plants his society was trying to save from vanishing, and asking him to help them along by begging his friends not to pick it, and especially not to break off its young shoots. Tommy's father and Grandmother can both remember when it grew near here, and when they found it just as often as they did Arbutus.

The Pitcher-plant in Francis's box had a flower much larger than the Laurel's, which looked something like a garden Rose. It was crimson and rather green inside, and it nodded over from the end of quite a tall stalk. I didn't think it was quite as pretty as a Rose.

The leaves were very curious. They were folded together in the shape of little pitchers without handles. Any one could drink out of them 
quite easily. Sometimes on this account the plant is called Huntsman's Cup, or else Sidesaddle Flower.

"Look at this sweet, sticky stuff that lines them," Grandmother said, "and see how many little bristles there are down near the bottom. Were you and I flies, instead of bees as we were playing, we should sip this sweet stuff, and then wander on to get more until we crossed the bristles, or tumbled into the rain-water that is still in the bottom of the pitcher. It's doubtful if we should ever get out alive, for if we escaped drowning, we could not walk up over all those glass-like bristles. We should be prisoners for life, and as this plant, like Venus's Fly-trap, has a taste for animal food, it would digest us in a way of its own.

Francis had found the Pitcher-plant in a sphagnum bog, the only place he knew of where it grew.

There was still a little tuft of earth about the Pitchers, and Grandmother thought if we planted them and kept them in the library window they might live for a long time. We are also going to feed each Pitcher a fly a day, so that they need not die from being hungry.

Tommy is out now in the woods trying to find something as beautiful as the Laurel and Pitcherplant to write Francis about.

Sallie's letter was not as long as Francis's. She was so busy with her " intentions" that she hadn't much time. She is planting a garden of vanish- 


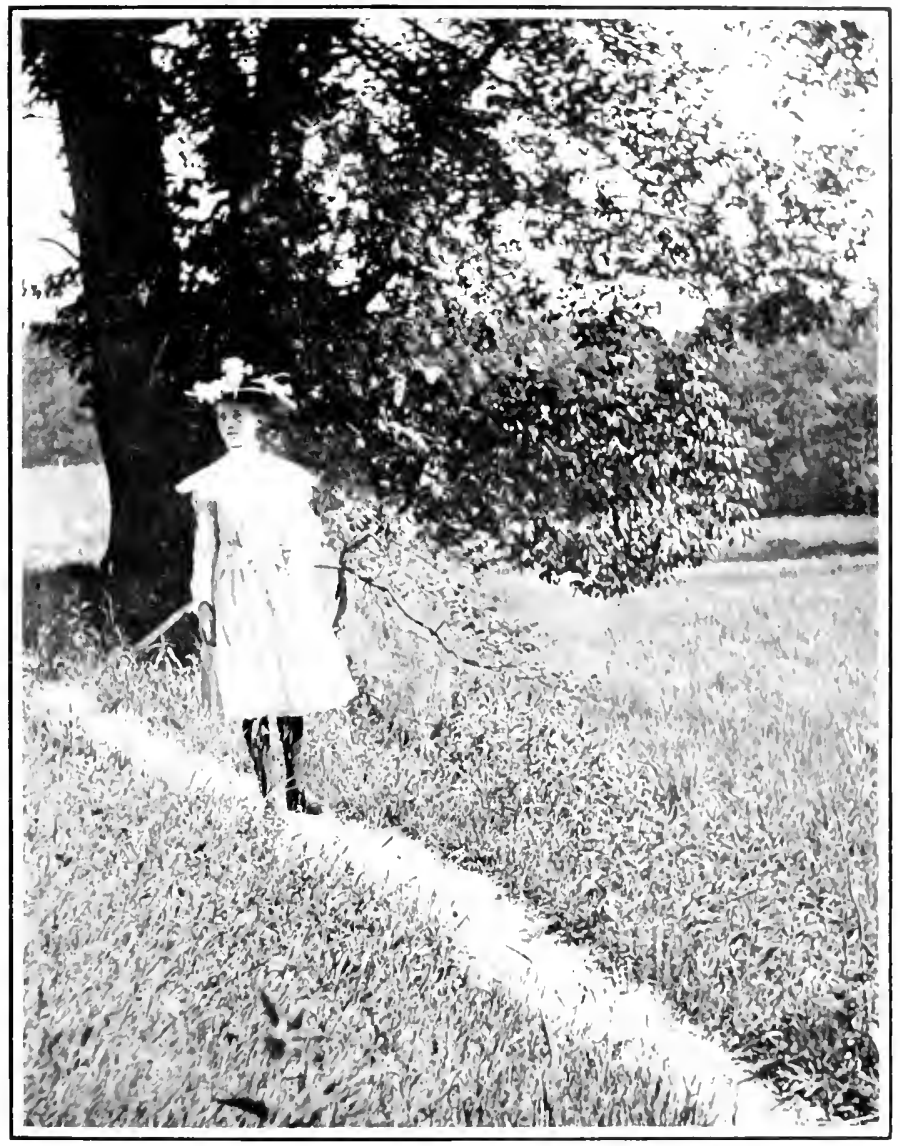

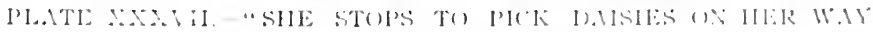
I10.11:" 


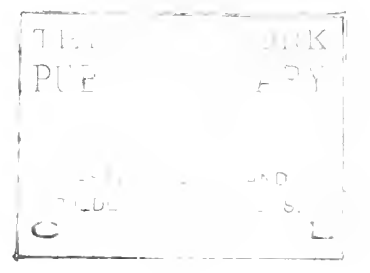


ing wild flowers, and it was to give it a good start that she took away Old Adam's earth.

This garden is in a very green spot back of her house, and away from the ocean. She has not planted very much there yet, because she has spent most of her time getting things ready. But one day in some woods she found a wonderful flower which she now knows to have been a Wild Orchid.

It was not a bit like the Large Yellow Lady's Slipper, for that had one of its flower leaves in the shape of a balloon, while in Sallie's Orchid the same leaf was quite flat, and all around it there was a tiny fringe. Only one flower grew on the stem, and but one leaf at the stem's middle.

The name of Sallie's Orchid is Rose Pogonia, or Snake-mouth. It has a very faint, sweet scent, and she writes that it is a dear little thing. She has planted it in her garden, for she remembered how Herr Wilhelm Fritz took up the Yellow Lady's Slipper so that it didn't die, and she was able to do the very same thing.

Sallie wrote that she didn't know very much about Rose Pogonia, except that it was rare and that it was vanishing. So she thought it a good one to start her garden with. Beside it she planted a clump of ferns, for she is trying to make the garden look like the place in the woods from which she took the Orchid.

Sallie has quite a long walk from her house to the woods, but she doesn't mind because she goes 


\section{FROM FRANCIS AND SALLIE}

across a meadow, and there Daisies and Buttercups are growing. She stopped to pick them on her way home, and she has a great bouquet of them in a jar on the veranda.

"They are not vanishing," she writes. "I know Farmer Higgins laughs when I pick them, and thinks to himself: 'Miss Sallie is helping me weed my pasture.' "

She says her next letter will be longer. 


\section{CHAPTER XXIV}

HELPING WEED THE PASTURE

AfTER reading about Farmer Higgins in Sallie's letter, I asked Tommy if there were not some farmers near here who would like us to help then weed their pastures. Tommy and his father and Grandmother have talked so much about vanishing wild flowers, that I thought it would be fun to find some that we could pick and pick until we were tired.

Tommy answered: "Uncle Hiram wouldn't make a fuss if we should go and help him weed his pasture, for he's got a field so covered with Daisies and Black-eycd Susans that the color of the grass can't be seen."

Daisies are just coming out in our meadow, and they give it a bright, pretty look. I remember that most people in the city love Daisies, but here it is a great disgrace to have them in the pastures. People like Uncle Hiram don't secm to know they are Daisies-he calls them "white weeds."

When many of them are in a field and it looks as if soft clouds had dropped on it from the sky, the farmers say, "Poor land, just covered with weeds."

I put on my frock of blue jean the day we went to help Uncle Hiram, and 'Tommy had on his old school suit. I 'spose it's a little harder work pull- 


\section{HELPING WEED THE PASTURE}

ing up weeds than picking Daisies, although when the weeds are Daisies it isn't easy to explain the reason.

We walked by the road to Uncle Hiram's, for that is the nearest way. We met Philip and he turned back and went with us. Philip is the only boy we know who really likes Uncle Hiram, and isn't one bit afraid of him. That's because Uncle Hiram has been his friend since the day he made him promise never to cut Dogwood again.

Tommy said we would go and pull his bell and ask if he wanted helpers; but Philip thought we wouldn't have to do this, because he knew Uncle Hiram was always in front of the house looking out to see if any one was near his Cherry-trees. We found him standing by the gate-post, and the first words he said were:

"Didn't expect to see me here, hey!"

Tommy said if he hadn't been there we should have pulled the bell, because we had something to ask him.

Uncle Hiram made a queer sort of noise and said: "Well, what is it?"

"We should like to pull up the Daisies in your meadow, because they make the land poor," Tommy answered.

"Real neighbor-like," Uncle Hiram said, and pulled one of my curls. "Used to know your Grandmother when she was a girl."

$\mathrm{He}$ looked at me in the funniest way, and then 


\section{HELPING WEED THE PASTURE 153}

I asked him if he would let us pick the Daisies from his pasture. He saw I had my basket with me.

"Perhaps you'd rather I'd fill this basket with cherries?" he said.

"Grandmother has plenty of cherries," I told him.

He laughed at that and asked Philip how much he wanted for clearing his pasture from white weeds.

"We'll do it for a quarter a hundred," Philip said.

"I can get it done cheaper," Uncle Hiram answered.

"Not by us," Philip told him very proudly.

Uncle Hiram smiled again and asked me, "You in this bargain?"

I was going to tell him that I only wanted to pick a great many Daisies to make a bouquet for our veranda, when Philip pulled my sleeve and winked, and Tommy nudged $m e$ in the back. I said, "Yes."

"Let me see," Uncle Hiram said, " if you each pull a third of a hundred, that's less than thirtyfour apiece, and if you divide up the quarter it gives you each a little more than eight cents. Eight cents for pulling up thirty-four weeds is pretty good pay."

Philip said: "It's hard work pulling white weeds." 


\section{HELPING WEED THE PASTURE}

"How many hours a day do you calculate to work?" Uncle Hiram asked.

"Until we are tired," I said, and Philip gave me a poke to keep still.

"We'll work," he said, "until we have money enough to buy new jack-knives."

"Oh," Uncle Hiram answered, and he put his fingers in his beard. "Pears to me boys are less of a nuisance when they have no jack-knives."

"We'll buy rabbits then," Philip said.

"Rabbits are as big a nuisance as jack-knives," Uncle Hiram said. "They gnaw the bark off young trees and nibble on the prettiest kinds of shrubs."

"Perhaps you wouldn't mind our buying cameras," Tommy said.

"To take Uncle Hiram's picture? Well, I see no objection to that. I rather think the bargain's made. Remember you must pull the Daisies up by their roots, and come and lay them here on my well-step, giving me your word of honor there's a hundred in each bunch."

We ran off to the meadow very fast. It was white with Daisies. Buttercups were there too, and yellow Daisies with brown, hard centers, that Tommy and Philip both called Black-eyed Susans. It was these flowers that Uncle Hiram told Philip to be sure and pull.

I had a handful of Daisies in my basket very quickly and then I started to pick Buttercups. 


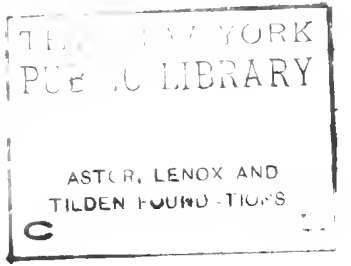


"You must pull them up by the roots," Philip shouted.

Then he and Tommy both said I needn't be in the bargain, but that I could help them. First I went with Tommy, and we pulled up Black-eyed Susans. I got fifty some time before Tommy. They were very hard to pull and hurt my hands dreadfully. Their stems were covered with sharp bristles that pricked.

Tommy said: "That's why Uncle Hiram wants to get rid of them; neither his horses nor his cows will eat the hay they're in. The sharp stems stick in their throats and make them sick."

Another reason I didn't like to pick Black-eyed Susans was because they nearly all had bees, or wasps, or flies, or beetles on them, which it was hard to brush away. I wouldn't have minded butterflies. I could see that these other insects were all hungry and trying to get the nectar which was in the hundreds of tiny florets packed together in the brown center cones. Tommy told me while I was helping him that Black-eyed Susan is really not one flower alone, but a whole colony of two kinds of florets. The yellow, narrow pieces all around the centers are called strapshaped flowers, because they are the shape of little straps; and the hundreds of tiny ones in the brown centers are called tubular flowers, because they are like little tubes.

Daisies grow this same way. So it is not only 


\section{HELPING WEED THE PASTURE}

the many Daisy heads we see over Uncle Hiram's field that would make and sow seeds for another year, but all the thousands of tiny florets that fill each Daisy head. It is no wonder I thought they were never likely to vanish, and children can pick as many of them as they please.

While I pulled another fifty Black-eyed Susans, Tommy lay down in the grass and only kept his eyes moving around after me to see that $I$ got them up by the roots.

Then I had to help Philip and all that time he sat on the fence. The Daisies were not so hard to get up as the Black-eyed Susans, so Philip thought I ought to pull two hundred for him, to equal the hundred Black-eyed Susans for Tommy.

There were tiny, crawling black things on the Daisies' yellow centers, and sometimes they got on my hands. I didn't mind them much though and Philip helped me to brush them off in the grass.

We had only a little corner of the pasture cleared when I felt sure it was time to go home. My hands were sore and I ached in the back. We took the Daisies and Black-eyed Susans and put them on the well-step, and then we tried to find Uncle Hiram. He was no longer by the gate-post, nor anywhere in sight. Some one called out the window that he had gone to the village and that he didn't expect us back so soon.

We thought perhaps we might meet him on the way and we started along the road. We 


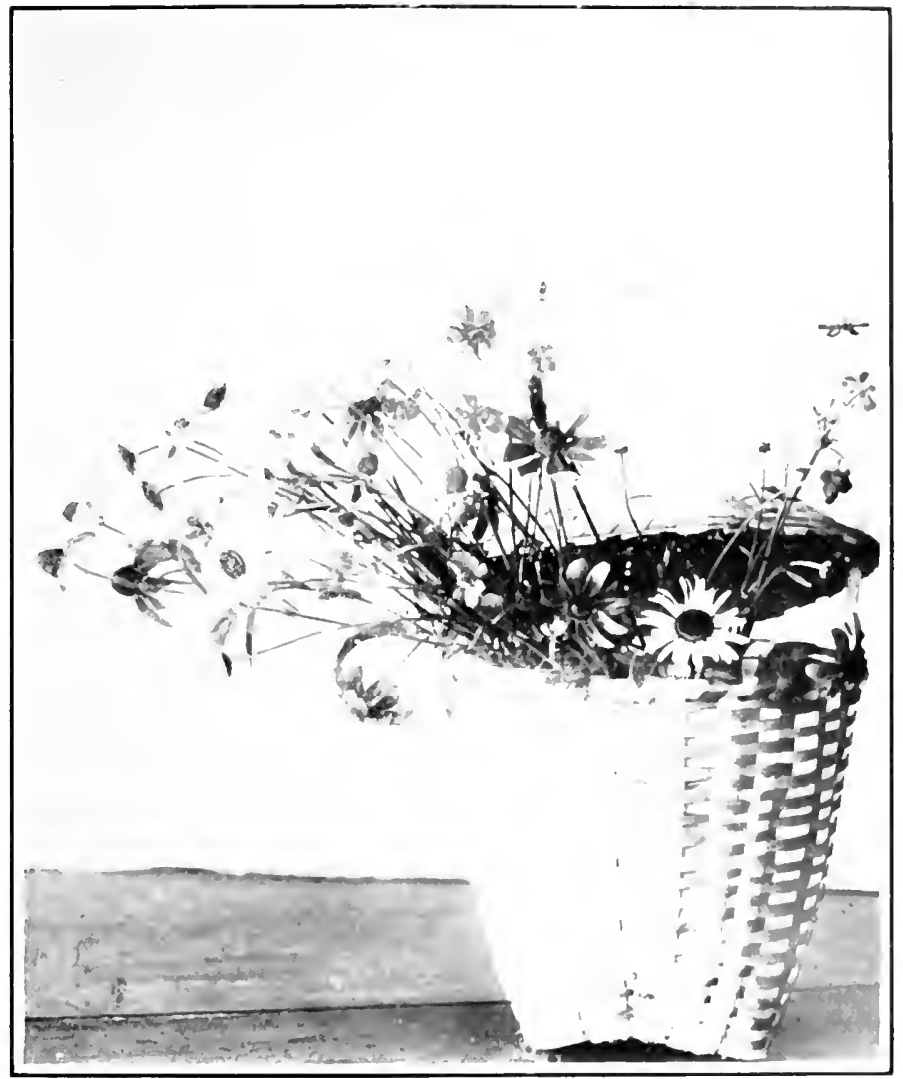

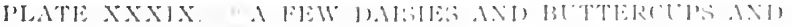

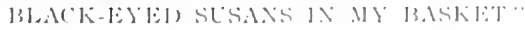




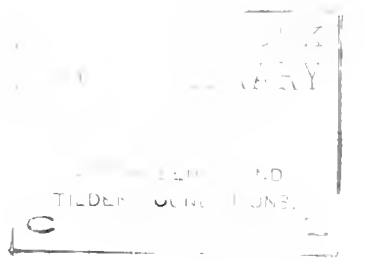




\section{HELPING WEED THE PASTURE 157}

reached Tommy's house without seeing him and then Tommy and Philip decided they would go back in the afternoon and settle the bargain. The boys said again that I wasn't really in the bargain, and that the twenty-five cents for each hundred that they were going to divide between them wouldn't be half enough to buy cameras.

I only had a few Daisics and Buttercups and Black-eyed Susans in my basket, and they didn't make a very big bouquet for the veranda. I think the next time I weed the pasture I will go by myself to Grandmother's back meadow. Sallie wrote in her letter that she went quite alone. 


\section{CHAPTER XXV}

ST. JOHN'S-WORT FLOWERS AND WITCHES' WORK

Yesterday was Sunday, and Mrs. Todd made both Philip and Tommy drop into the plate at church the money that Uncle Hiram had given them for pulling up the Daisies and Black-eyed Susans. Afterward I heard Philip telling Uncle Hiram about it. He put his fingers in his beard and said it might suit all parties just as well if he got rid of the weeds by running the mowers over them before they went to seed. I am beginning to like Uncle Hiram. There is something kind about him, and it makes me laugh to see him stroking his beard in that slow, soft way, as though it were a kitten.

In the country June goes by very quickly. This morning it is the twenty-fourth of June and Herr Wilhelm Fritz asked me if I knew it happened to be St. John's day. I said "no," and then $I$ asked him why St. John had a day all to himself. Herr Wilhelm Fritz said I could find that out at Sunday-school, but that it had nothing to do with what he had to tell me.

"Der's a number of plants called St. John'swort," he said, "dat's named fur der goot man, and dat all pegin ter ploom on dis day." 
"Do they have pretty flowers?" I asked.

"Der flowers is yellow, and all der different kinds of dem look alike, and yet dey are different. Der are some of dem dat are veeds."

"There's a plant in the pasture where the cows are," I told him, "that has small, pointed, yellow buds at the ends of nearly all its little branches, and with many leaves growing on its stems. It looks like a leafy, little bush."

"Dat's vun of dem," Herr Wilhelm Fritz said. "It has opened some of dem flowers to-day already. Dey hev five leetle petals vid plack spots on dem, and in der center of der flowers der are many what you call leetle things."

"I call them stamens now," I said.

"Vell, dat's petter; and it's very goot dat der first St. John's-wort you hev seen is from Wilhelm Fritz's country. It is not an American. Dat plant comes from Europe. It is called der Common St. John's-wort, and it is der vun dat all der superstitions is apout."

Grandmother came into the garden then and asked Herr Wilhelm Fritz if he were filling her little girl's head with witch stories.

"Only just der wuns dat she should know apout," he said.

Then they talked of Roses and other things, and presently it was luncheon time and I went in with Grandmother.

I kept wishing I might hear Herr Wilhelm 
Fritz's witch stories, and I asked Grandmother if she knew what they could be.

She said Wilhelm Fritz believed more in witches than was sensible, but that she knew a story for St. John's day, and that if Tommy and Philip came in the afternoon she would tell it when she was taking her tea.

I ran over to tell this to Tommy, so that he would surely come, and then we went for Philip. On our way across the meadow we looked for the Common St. John's-wort.

Just as Herr Wilhelm had said, ever so many of the buds had unfolded and the little plants looked quite proud of their bright, yellow flowers. Tommy said his father had told him this countryman of Wilhelm Fritz's was just as much a weed as Daisies and Black-eyed Susans, and that the farmers couldn't bear it because it devoured their soil.

"From now on," Tommy said, "we'll find it in lots of places, and often along the roadsides. But because this one is from Europe doesn't mean that our country has no St. John's-worts of its own. There's one I see often with smaller blossoms than this, and not so many stamens in the middle. It's not very pretty. Professor Bonn calls it Smaller St. John's-wort.

"The prettiest one that grows about here," Tommy went on, “ is Shrubby St. John's-wort, although to myself I call it fluffy instead of shrubby. 


\section{ST. JOHN'S-WORT FLOWERS 161}

It would take an hour or more to count all the stamens it has sticking out from the middle of its yellow flower leaves and making it look like a ball of down. Besides you can learn to tell it easily because its stems are bright reddish. It doesn't grow much about here, the soil isn't quite sandy enough. I saw it often last year when father and I were in New Jersey, and I suppose Sallie sees it where she lives on Long Island."

A queer thing about all the St. John's-worts is that their leaves have little black spots on them. Sometimes in early spring I could hardly tell the plants themselves, if I didn't look sharp for these spots. In spring, you see, they look exactly like weeds, for their buds are not even formed then.

At first I couldn't see the black dots; but when Tommy held a leaf up before my eyes it let the light through in ever so many little holes no larger than the point of a pin.

When we found Philip I told him he'd better look at the St. John's-worts before hearing Grandmother's story; but he said he'd wait, and if it was a good one he'd fecl more like going out and bowing to them afterward.

We thought Grandmother never would come home from driving, but when she did and we all sat close up to her in the library, she began:

"When I was a little girl I had a German governess. She used to tell me wonderful stories about fairies and little people, but always when I 
asked her if they were true, she said, 'no.' One day, I remember it was the twenty-third of June, St. John's-wort eve, Fräulein was very busy. She ran out to the pasture and gathered some St. John's-wort, and this she sewed in a little bag and hung it around her neck. She put another sprig of St. John's-wort over the kitchen door and still another over the door to her room. Then after dusk she went again to the pasture and bathed her eyes with the dew that had fallen on the plant.

"I was very curious to know why she did all this; but the only thing she told me then was that she had bathed her eyes with St. John's-wort dew to keep her sight from growing dim. Her eyes were very sharp, I knew, and it did seem strange that she could keep them so by just one night in the year putting the dew on them that fell on a St. John's-wort plant. But Fräulein thought this was true, and I suppose Herr Wilhelm Fritz would tell you the same story, for it is believed by many young girls and men in Germany.

"That same evening Fräulein talked very little. It was not until the next day that she told me all that happened.

"Before Uncle Hiram made the west road through his place there was a narrow path there called Witches' Lane, and many people thought a witch lived in an old house close by. It has since been torn down. Fräulein had heard about this 


\section{ST. JOHN'S-WORT FLOWERS}

witch and wanted to see her, but she was afraid. So she waited until St. John's eve when she believed that if she wore a piece of the plant hung around her neck, the witch would lose her powers for evil over her, and she also believed that no other evil spirits or witches could enter her kitchen or room while she was away because she had hung pieces of St. John's-wort over the doors.

"After Fräulein had put me to bed-in those days I used to go to bed at dusk-she started off for Witches' Lane. She went as far as she could by the road, for she said if she had stepped on a St. John's-wort in the meadow that the fairies would have been so angry they would have carried her off against her will. When she came to the lane she ran along quickly. Every minute the light was fading, but before she could see the old house, something made her look up and just in front of her stood the witch.

"Fräulein said she knew at once she was a witch because she had a look quite different from any other old woman she had ever seen. She held out a piece of St. John's-wort, and she was singing a queer sort of song that Fräulein could scarcely understand. It appeared as though she saw something very far away.

"When the witch saw Fräulein she cast an ugly look at her, but she could do her no harm because Fräulein was protected by the little picce of St. John's-wort in the bag around her neck. Most 


\section{ST. JOHN'S-WORT FLOWERS}

witches, Fräulein thought, would rather do people harm than good.

" 'Mother,' Fräulein said, ' tell me how I shall get my wish.'

"At first the old woman paid no attention to Fräulein but went on singing her song.

"Fräulein said again: "Tell me, Mother, how. I shall get my wish."

"The witch went on singing.

"The third time Fräulein asked: "Tell me, Mother, how I shall get my wish.'

"Then the witch turned around and gave such a sharp grunt that Fräulein would have been frightened out of her wits had she not clutched the St. John's-wort hanging around her neck.

"' 'Begone,' the witch cried, 'and marry the first man who comes in at the door in the morning.'

"Fräulein ran back a good deal faster than she had gone down the lane, and that very night she dreamed of the milkman, and that he wore a sprig of St. John's-wort across his shoulder.

"Sure enough he was the first man to come in the kitchen-door in the morning, and she married him before the summer was over. Uncle Hiram used to say that old witch was the milkman's mother, so perhaps she knew all the time how things were going to turn out.

"Anyway," Grandmother said, "that's all I know about witches and St. John's-wort." 


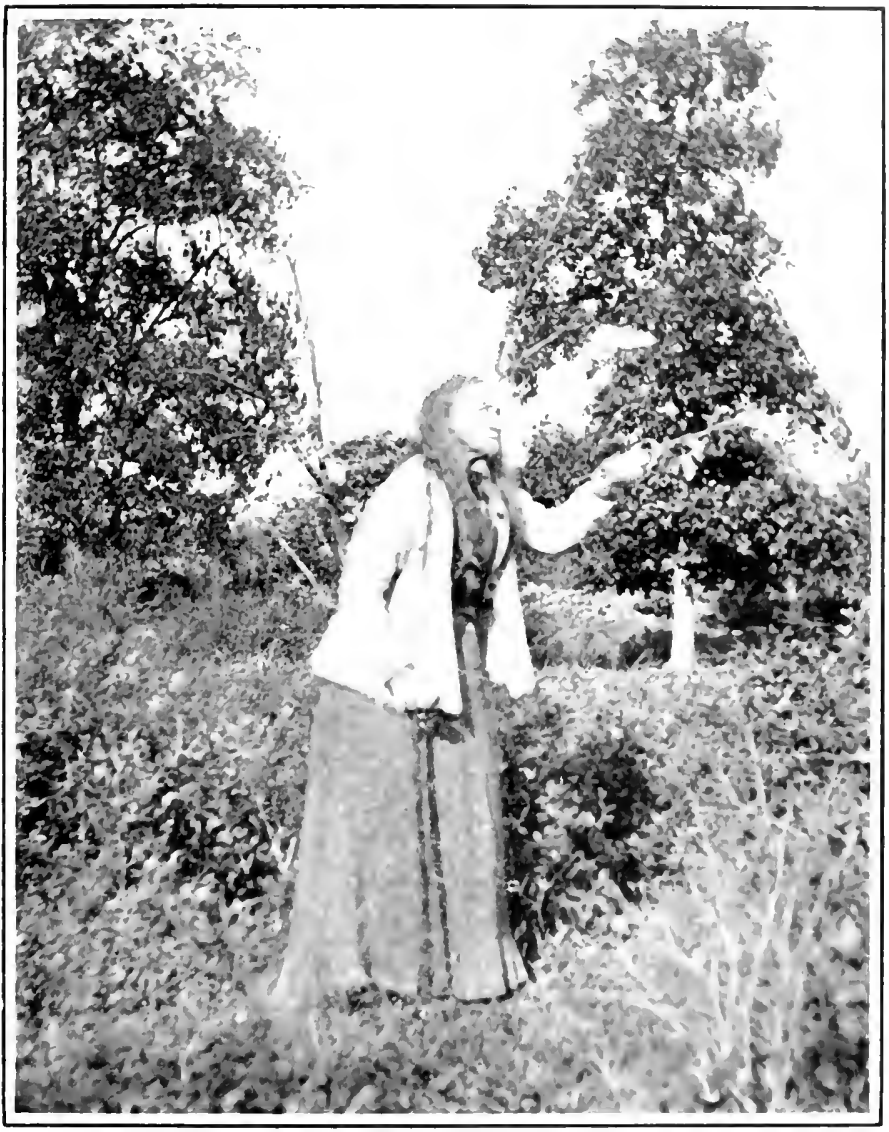

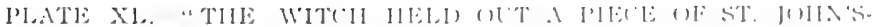
HURT" 


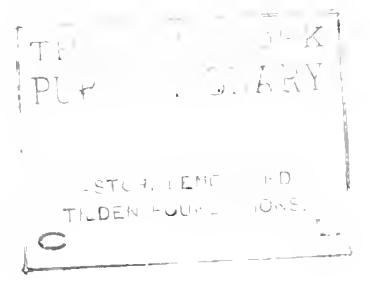




\section{CHAPTER XXVI}

WHEN TOMMY AND HIS FATHER WERE AFIELD

WHEN Tommy goes hunting with his father for wild flowers, they always find something that is wonderful. It is not only wonderful because it is pretty, but because it has wonderful ways. Nearly every Sunday afternoon they take a long walk together and on their way home they stop to see Grandmother.

Last Sunday it looked so much like rain that they went no farther than our own woods. At first nothing the least like an adventure happened. Hardly any flowers were in the woods, Tommy said, for Rock Pinks and Wild Geraniums had faded, and both the true and the false Solomon's Seals were making their berries. Even Wild Rose had gone to seed, and it was only possible to find a Wild Strawberry now and then along the highway.

Last Sunday the woods were very green. Most of the leaves are full grown now, and some of them have a dusty, old look, and make me think they are just as different from what they were in early spring as Grandmother and I are different. Tommy and his father left the woods after 


\section{TOMMY AND HIS FATHER AFIELD}

they had been there awhile and walked along the little path that leads to the village. There is a stone wall by one side of this path, and high bushes stand beside it which Tommy says bear Choke Cherries. They are not quite ripe yet, but even if they were they would have a puckery, choking taste that would make anybody dislike to eat them.

While Tommy was looking at the Choke Cherries his father called out: "I believe that's Spreading Dogbane. Yes, surely it is Dogbane."

Tommy had never noticed the plant his father pointed out, although he is so quick at seeing things out-of-doors. But the Dogbane grew close to the Choke Cherries and their leaves slipped in and out together. It was because it had just opened its flowers that his father saw it so quickly. Tommy climbed right up on the stone wall and took some of the Spreading Dogbane in his hand. It was a new flower to him, and of course he saw it was very beautiful.

I can't exactly tell how Tommy feels when he finds a new flower; but I know it makes him very happy. He says when he's a man he hopes he'll discover some flower that even botanists don't know about. This he thinks would be just as fine a thing for him to do as it was for Columbus to discover new land. But before he can do this he has to learn all about the flowers that are already known and have their histories written.

At first the Dogbane flowers looked to Tommy 


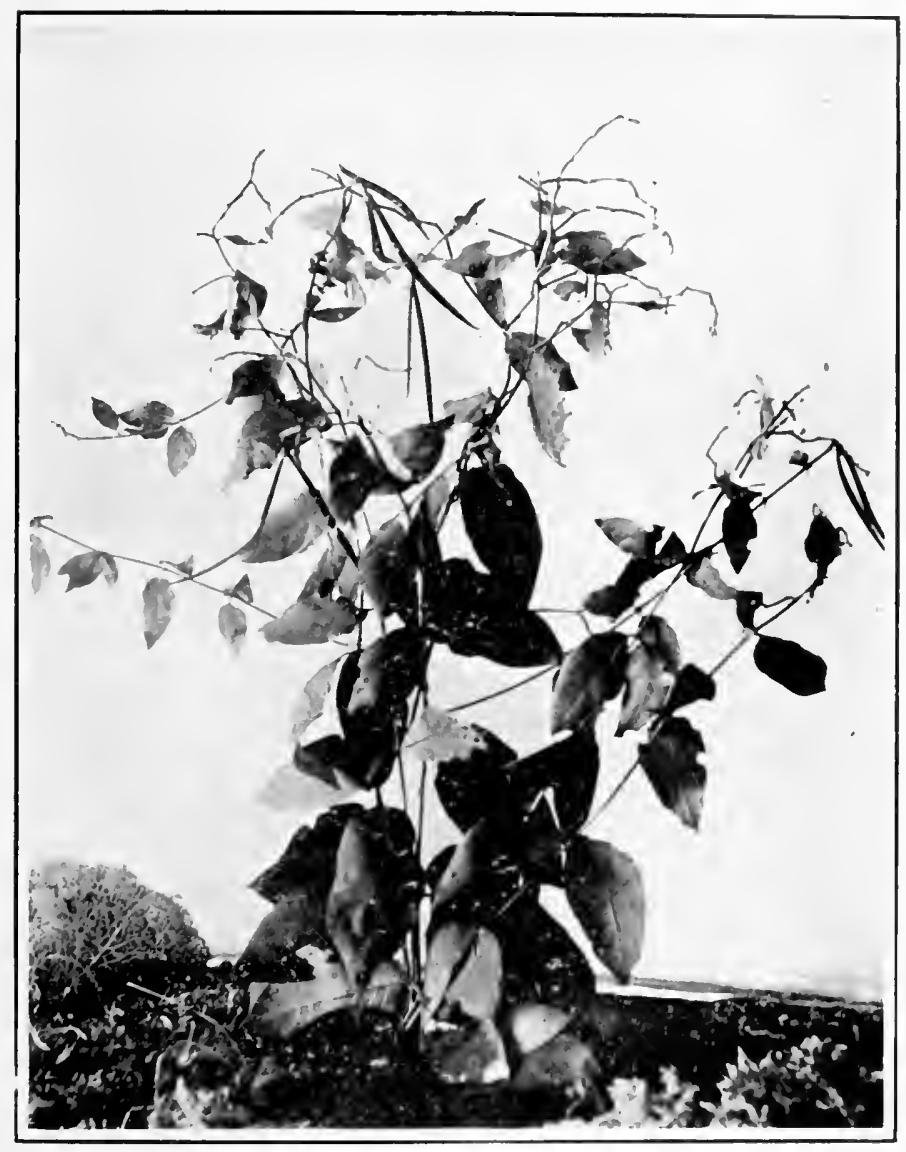

PLATE XLI,-SPRLADING WMIHANE 


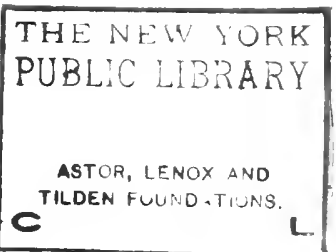


like Lilies-of-the-Valley, although they grew on a large spreading bush instead of a little two-leared plant. Besides, the leaves of the Dogbane grew just opposite to each other on the stem, and had no little dents, or curves around their edges. It was really only the flowers that reminded Tommy of Lily-of-the-Valley.

They were the same shape, but a faint rose color, and five deep, pink lines ran through them. What pleased Tommy best of all was their very sweet scent. He even thought it sweeter than the Honeysuckle on our veranda.

Tommy's father asked him: "Why do you suppose these little flowers have these pink veins? Is it just to make them pretty, like stripes in a lady's gown?"

Tommy didn't answer right away, for his father often said to him: "Think twice before you speak once."

While Tommy was taking the second think, he remembered Blue Flag, and all that Professor Bonn had told us about its purple vein being the bee's royal road to a feast. So he answered:

"Perhaps it's to show Master Bee the way to find something good to eat."

"Not Master Bee this time, but Sir Butterfly," his father told him. "He's guided by those pink lines to run his long, slim tongue down to the very center of the nectar feast. But the ly (whose tongue is short) as well as other little in- 


\section{TOMMY AND HIS FATHER AFIELD}

sects with no intention of carrying the golden dust, get caught in one of the five V-shaped traps which lie at the ends of those pink lines.

"These little traps, besides, have horny teeth, and when they close on the fly's tongue he is held a prisoner until he dies. It's pretty hard to starve to death when so near a luscious feast."

Tommy looked in the little flowers and saw a number of mites and two flies that had met this death.

"They go to steal," he said, " and are made life prisoners."

When Tommy told me about it I thought the little flowers acted in a cruel way because the flies don't know it's wrong to steal nectar.

On one of the sprays of Spreading Dogbane which Tommy brought to show us the pods were nearly ripe. Two of them hung together and Grandmother said they were quite three inches long. They were more slender than a lead pencil. We all thought them very big and important-looking for such little flowers to have made. Then Grandmother picked one open with a pin, and inside it was closely packed with seeds all covered with white, silky hairs. These hairs help the seeds to sail through the air when they are ripe and ready to find new places to plant themselves.

"A truly lovely wild flower," Grandmother said, "how glad we are to know it grows by the stone wall!" 
It seemed as though Tommy had told us all he had to say about Spreading Dogbane, yet he sat still in his chair and said he hoped tea wasn't ready. His father was smoking outside. I asked him if he knew anything else about Dogbane and he answered:

"It's called Honey Bloom by some people and Bitter Bloom by others who believe it's poisonous to dogs. I rather think though Peter 'll know enough to leave it alone. He's not getting his tongue caught in a trap like stupid flies."

We thought surely he was through then, and were just going out on the veranda when Tommy said: "Something else happened to-day," and before anybody could ask him what-"I've seen the girl from Secret Valley. Father saw her too."

Grandmother sat down again. "Tommy," she said, "you have saved the best until the last. Next you will be telling us you know her name and whether she has brothers and sisters."

"We thought the rain was getting nearer," Tommy began, " and were walking quickly by the side of the meadow to take a short cut here. It's there that the Wild Yellow Lilies, or Meadow Lilies are in bloom. I showed them to Philip the first day a bud opened. They're those Yellow Lilies, spotted with brown, and which nod over from the ends of high stalks. 'They're just as beautiful as garden Lilies, I think, and it's finc 
to see their leaves growing so nicely in a circle about the stems. I love these Wild Lilies and was just going to point them out to father when I saw that strange girl snuggling down among them. She looked as though she were leaning over to whisper something to them. Her hair hung straight by the sides of her face just as it did in Secret Valley, and she was as still as when she stood there on the stump.

"I gave father's coat-sleeves a tug and told him to look. He did, but not at the Lilies I meant, for at first he didn't see her. Then I whispered to him to look at the Lilies where the high Milkweed was in bloom and that time he saw her quite plainly.

"The queer thing about it was that when we got close to those Lilies she wasn't there, yet neither of us had seen her jump up and run away. An Elder-bush near by was covered with large flat bunches of fragrant, white blossoms, and I thought perhaps she might have slipped in there to hide, while father and I were talking. I ran all around the bush and parted its branches, but all I saw in them was an empty robin's nest."

Grandmother laughed. "This time, Tommy," she said, "your strange girl is the spirit of the Meadow Lilies instead of Secret Valley."

Just then Tommy's father came in. He said: "She was no spirit, for in her hair she wore a bow of white ribbon very like your little girl's. I 


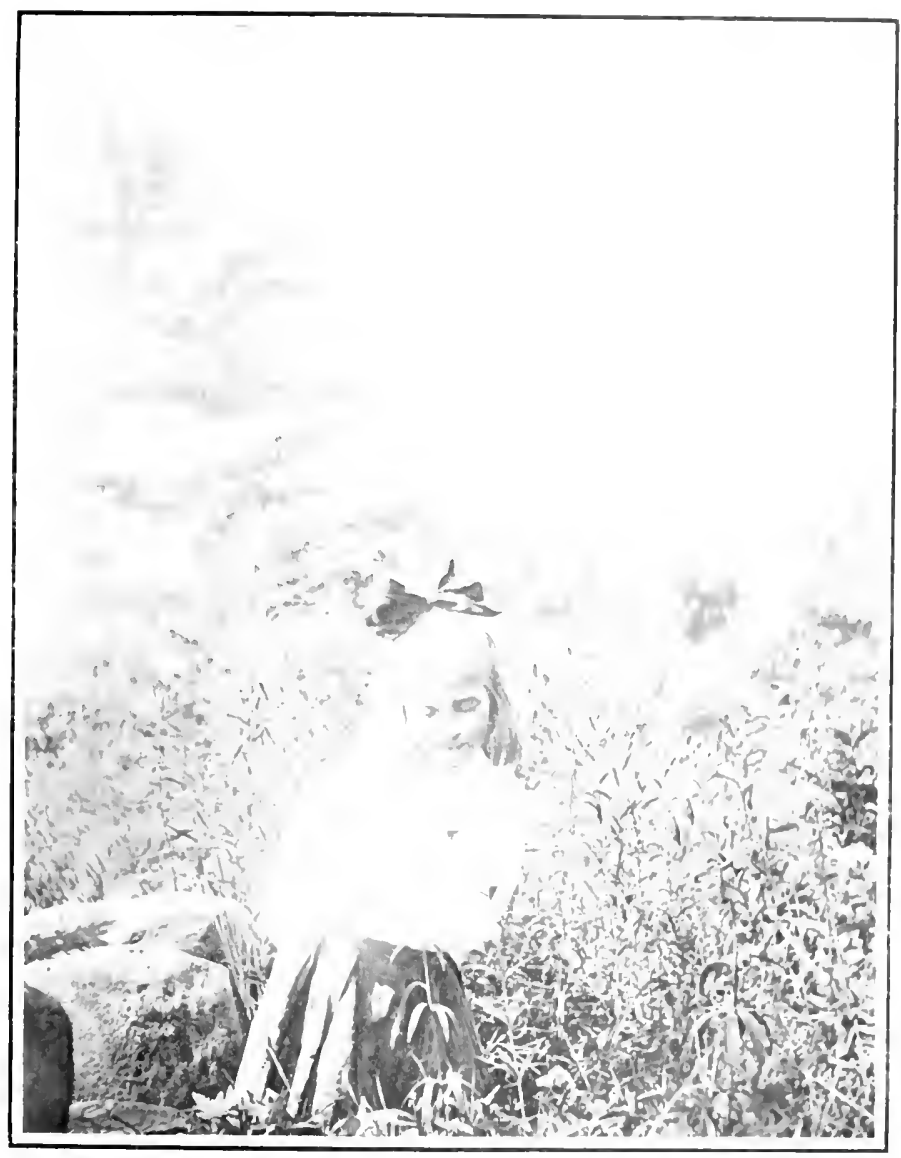

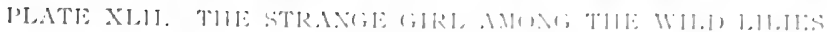




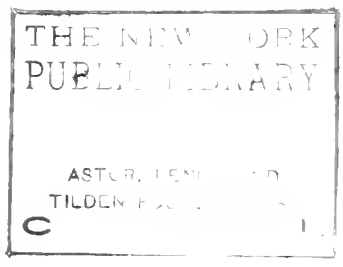




\section{TOMMY AND HIS FATHER AFIELD 171}

think it was tied to make the flowers believe it was a butterfly."

"When I saw her by Old Adam she had a Dogwood blossom in her hair," I told them.

"Anyway she is light of foot," Tommy's father said. "We should have to take a mile at a hop and a furlong at a skip to catch up with her. Tommy will have to see the good fairies that attend to such matters and get them to stretch him out a little."

But Tommy didn't like being teased about this strange girl and when they went away there was no smile on his face. 


\section{CHAPTER XXVII}

\section{PHILIP'S HUNT}

SINcE Tommy and his father saw the strange girl, Philip Todd has been out looking for her almost every day. He has sat in the woods watching about old trees and shrubs, and he has even been to Secret Valley. It isn't often he goes there, and this time he looked around for her until his ideas got twisted, and he took a wrong path to get back to the pool. He never reached the pool again.

It was about four o'clock in the afternoon when he gave up looking for her, and he didn't hurry as he went along the wrong path. He came to a place where there were the greatest number of white flowers. He thought they had been asleep and were just awakening; for every minute or so one that looked like a bud would slowly open.

"They're a lazy lot," Philip thought, " even if they are pretty. A great time in the day this to be peeping open. They're more drowsy than Spring Beauty."

It was cool and still in the woods where these flowers were, and Philip thought as he could not find the strange girl, he might just as well watch 
them awhile. Each one had five delicate white leaves, or petals, as I should say, and around their edges they were cut in strips, just as though they had ordered themselves to be fringed. Philip noticed that many little insects that had tried to crawl up the stems were held by something and could go no farther. Then he felt the stems. They were sticky. This made him remember Rock Pink, and he wondered if this white flower could be related to it, since it had the same way of holding fast the insects that were trying to crawl up its sticky stem to steal nectar. Butterflies flitted about; they had no need to walk on the stems, and a grasshopper that jumped on the plant was so big and strong that the stickiness made no difference to him.

Philip didn't know the name of this flower. $\mathrm{He}$ had never seen it before. He wondered if he' $\mathrm{d}$ found a new one that was not even in Tommy's books. It would be fine, he thought, to astonish Tommy, and write about his discovery to Francis. He took another long look to make sure he hadn't missed secing anything.

The leaves! he had almost forgotten them. They were long and pointed, and near the middle of the stems four of them grew in a circle. At other places, he noticed, there were only two, and they were opposite each other. The plants came about up to his chest, and as Philip is a tall boy for his age, they must have been a good deal higher than Rock Pinks ever thought of growing. 
At last, after he had picked a sprig of this flower, he started on. He kept following the new path, but instead of its getting wider, or leading him to the pool, it grew narrower and soon he could hardly see that he was in a path at all. Woods were all around him. He went up by a group of chestnut-trees to wonder a little where he could be. A bird flew out and called " chewink, che-wink."

"I know that's your name," Philip answered, "and what you say when any one visits you in the woods."

"Chewink, towhee," the bird said and went and sat on a limb quite close to Philip. The white tips of his tail feathers, which he kept moving, reminded Philip of the flowers he had left. The chewink kept looking at him, and Philip was just thinking that his back was black, his sides reddishbrown, and that underneath he was white, when he heard the most horrible noise. It sounded once, and then again. Philip ran as fast as ever he could. He lost his cap and the sprig of white flower that he had hoped might astonish Tommy.

He never stopped running until he came to a stone wall, and when he tried to get over it there was barbed wire on top. This caught his trousers, and as he was pulling himself loose a stone slipped off the wall and made him fall. His foot was badly hurt, for the stone fell on it. The tears came to his eyes, and he had to hold his foot, the pain was 


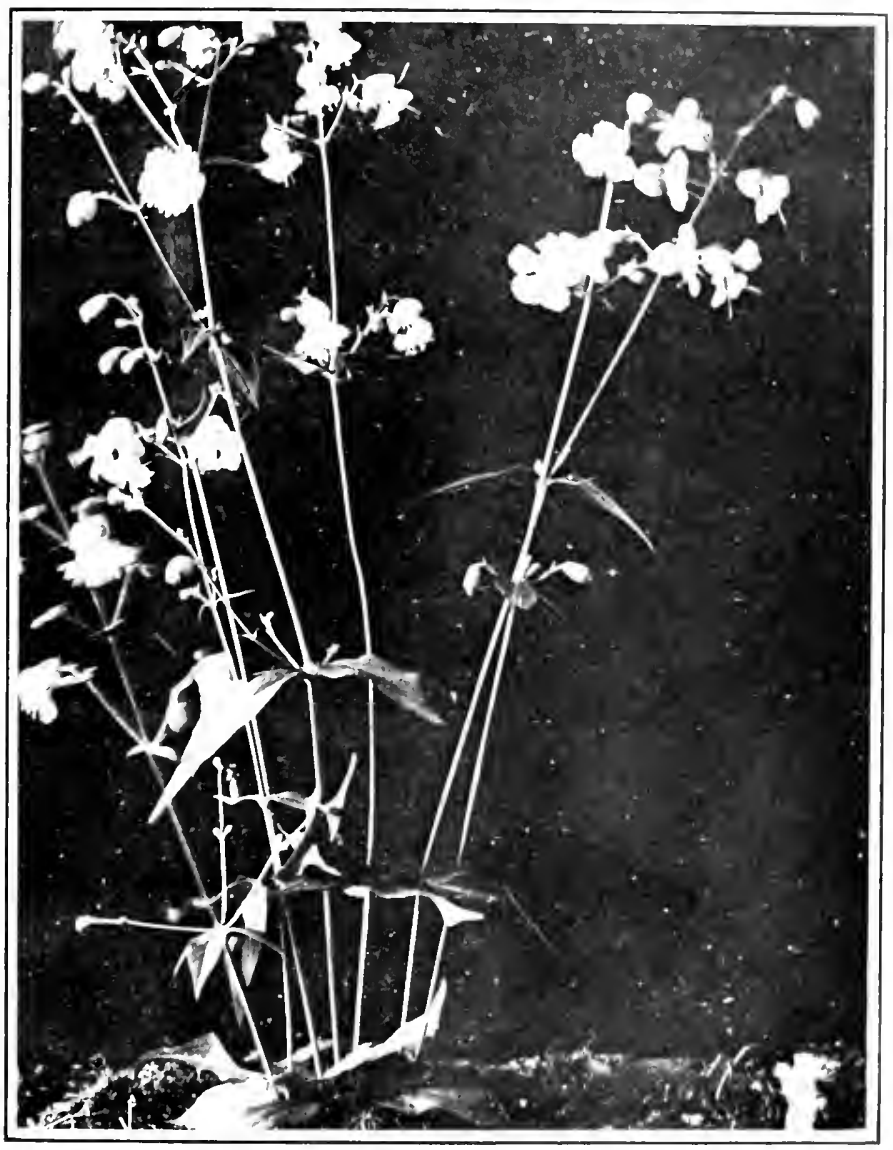

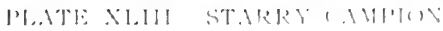




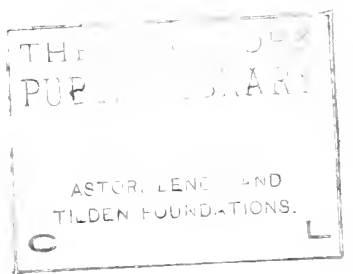


so great. Yet he couldn't help wondering about that loud noise.

He saw that the place he was in now was not woods, but a meadow, and it looked swampy. He didn't want to go back the way he had come, so he started to go across. The farther he got ahead the harder it was for him to walk with his sore foot.

In the middle of the swamp the water came up over Philip's boots. He had quite given up trying to keep dry and he stepped in the water as often as he did on the little hard hills of grass. Pretty soon he came to three planks that had been laid like a bridge over the water and from them he got on to drier ground.

There was something familiar to Philip about that rough bridge, and he saw many yellow flowers growing almost in the water, with fine swamp grasses all about them. The minute Philip saw those flowers he knew where he was, for he remembered that he and Tommy had found them in that very spot a year ago and that later Tommy had read in his books they were called Bulbbearing Loosestrifes.

They grew up tall and straight, and their flowers were all at the ends of the stems in long narrow bunches something like the way that hyacinths grow. Each little yellow flower had a brownish red center, and its shape was like a wheel. The plants had many leaves, and they were long and 
narrow. Philip remembered that these Loosestrifes sometimes bore queer little things looking like bulbs, instead of flowers, and that this was why they were called Bulb-bearing Loosestrifes.

The reason a whole family of these plants is called Loosestrife is because long ago a relative of theirs in Europe was believed to be able to stop cattle from quarreling. Farmers used to tie it on their yokes to loose their strife. I think perhaps cattle don't quarrel in this country, but anyway even Tommy's father has never seen a Loosestrife tied on their heads here, and if he did he says he should think it was to keep flies away.

Philip remembered all this when he saw the Bulb-bearing Loosestrifes, and he also knew then that he came into this meadow from another side than when he went there with Tommy.

$\mathrm{He}$ started on again, but his foot was so sore he could hardly walk at all, and part of the way he held it up and hopped on the other one. He was still a long way from home, for that swampy meadow is beyond Miss Amelia's woods.

Out on the road he saw Uncle Hiram coming along in his phaeton. Philip called out to him and Uncle Hiram took him in and drove him home. Uncle Hiram told him the noise he had heard was nothing but an old cow bellowing, and he laughed a good deal because Philip had lost his way. It was nearly seven o'clock when they reached Warley Towers, but it was still light, for 


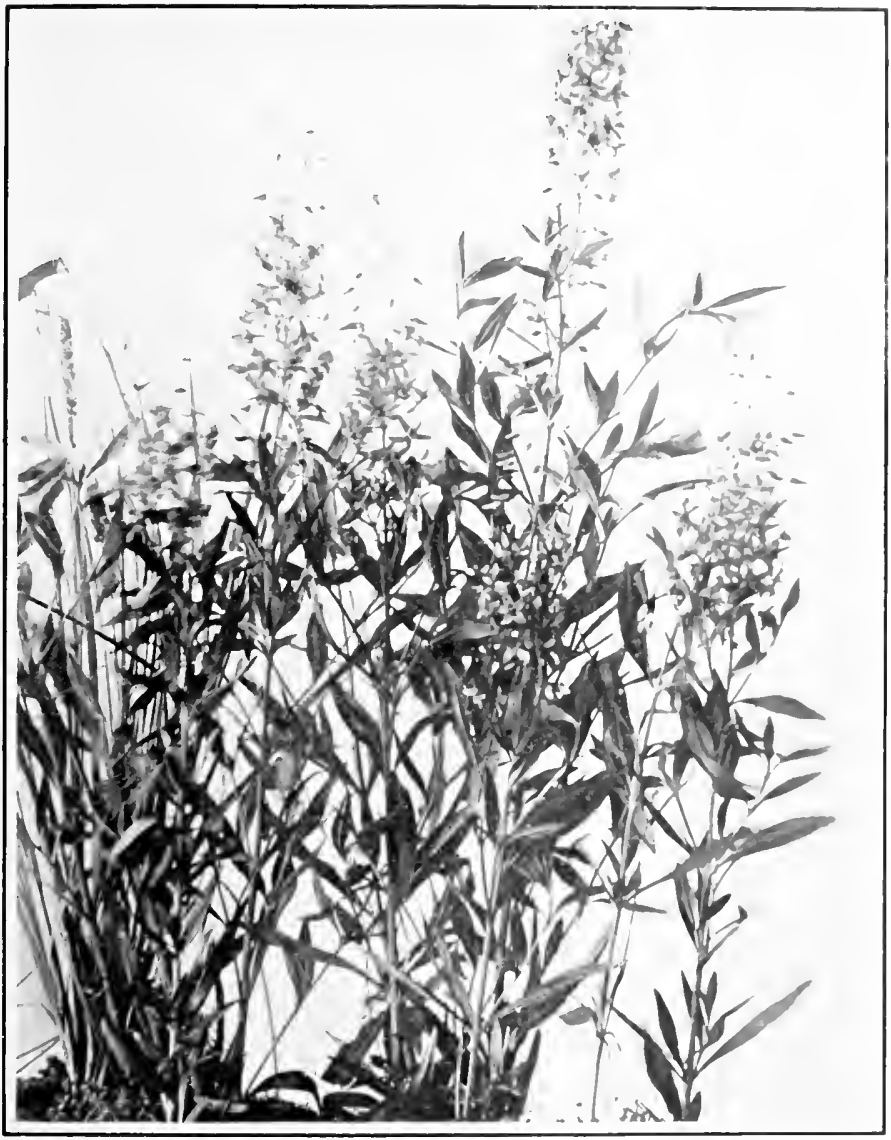

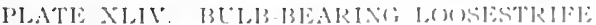


TH

$P \cup r$

LST.

,

in.............. 
after the St. John's-worts bloom we have the longest days in the year.

When Tommy found out that Philip's foot was hurt he went over to see him. He told Philip that he knew where he had found those white flowers, and that their name was Starry Campions. They're members of the same family as Rock Pinks, he said, and because they both have that stickiness on their stems to catch small insects they're called catchflies. This made Philip laugh, because he calls some birds flycatchers.

"Then I didn't find a new flower, and I didn't find the strange girl," Philip replied; "next time I'll have to look in other places." 


\section{(HAPTER XXVIII}

THE PICNIC ON OLD ADAM

IT was nearly a whole week since Tommy or I had been in the woods. But yesterday Philip's foot was better, and we had the picnic and ate our luncheon on Old Adam. Little Trudy went with us, although Tommy said he would have to tie a string around her waist to keep her from running away, We invited another girl also, whose name is Kate Hood. She is Miss Amelia's niece and has come to stay with her until school begins.

Kate is tweive years old, and quite used to the country, although her real home is in the city. She loves flowers, but she has never found Bloodroot's tissue-paper leaves, as Sallie did, nor seen the Large Yellow Lady's Slipper, and she doesn't think the little spring flowers are half so beautiful as I do. Yet she knows almost as much about the country as Philip and Tommy. She is about as tall as Sallie. Her hair is short and her face is tanned from being out in the sun. Yesterday, when we went to the picnic, was the first time she had been in our woods, or up on Old Adam.

We all started from Grandmother's, and Herr 


\section{THE PICNIC ON OLD ADAM 179}

Wilhelm Fritz carried the heary lunch-basket, although there were other little things that we helped him with. This was fortunate, for when we came to the rock Wilhelm Fritz had to take Little Trudy on his shoulder and carry her. We went up the side that is so steep.

When we were all up, the first thing we did was to begin unpacking the baskets. It was only eleven o'clock, but we were hungry, and Herr Wilhelm Fritz said we might as well eat first and play afterward.

Tommy and Philip started to build a fire-place so that we might roast potatoes. They made it of stone and earth in something the shape of an ant's house, only of course it was quite large. In the front they left a little opening for fire-sticks.

Herr Wilhelm Fritz said: "Dose vill be der pest potatoes dat you chilrun hev eat already."

Kate Hood and I spread the table. We laid the cloth over the place where Old Adam shows only bare rock, and right after that we saw that there were no knives and forks in the basket. We thought they had been forgotten. Tommy and Philip were much too busy making the oven to run home after them, so Wilhelm Fritz said "he vud make sum dat vud do very goot."

He went away for a few minutes, and when he came back he had a whole bundle of twigs under his arm, and was whittling very fast. A number of the twigs were just the shape of forks, and when 
he got the bark off they were smooth and white like satin. It was not so easy to make the sticks like knives, for they could never be real sharp.

Tommy stopped a minute from building the oven to look at the things Herr Wilhelm Fritz had made, and the minute he felt the wood he made a great scowl.

"That's Azalea wood, Herr Wilhelm Fritz," he said; "you shouldn't destroy those bushes."

"You like to eat vid your fingers, or wid chopsticks like Chinese?" Herr Wilhelm Fritz asked. "Dat vood is soft and goot ter vittle, and I hav" ter hurry up already."

Still Tommy was very displeased because he knew Wilhelm Fritz had been cutting the Wild Azalea bushes that were in bloom farther down in the wood and near the swamp. They were not exactly the same Azaleas that Grandmother and I had found along Wild Honeysuckle Lane, but they were so much like them that few children could tell the difference.

Afterward Tommy told me that instead of being rose color, their flowers were white, tinted with pink, and very, very fragrant. Then they waited until the leaves were all out to unfold, while the one Grandmother and I found, opened both its leaves and flowers at the same time.

"This one likes to grow near water," Tommy said. "It is called White Swamp Honeysuckle, 


\section{THE PICNIC ON OLD ADAM}

or else Clammy Azalea, because the flowers have a clammy, sticky feeling."

I said, "I suppose that's to keep little mites away from its nectar," for I was getting used to this trick of flowers.

"Dat goot pipe you like ter see Wilhelm Fritz smoke is made from dis vood, Master Tommy. It's just an old vild vun, anyway."

Tommy went back to finish building the oven, for he knew it was no use talking with Wilhelm Fritz when he began to call wild flowers, " just old vild vuns." He knew, too, how fine the White Swamp Honeysuckle wood was for whittling, although he would never take it himself because the shrub is vanishing.

We went on setting the table when Herr Wilhelm Fritz had the knives and forks ready, and then we found there was nothing to eat with them. The bread was all made into little sandwiches, and the chicken was already cut in pieces to take up in the fingers. There was one great big knife in the basket, and that was for cutting the pic and cake. We didn't need either knives or forks to eat the hard-boiled eggs.

Herr Wilhelm Fritz said he'd never "vittle no more," and he was almost as displeased as Tommy until Philip said we could each take one of his knives home for a paper-cutter, and that we would need the forks as soon as the potatoes were roasted. Then Herr Wilhelm began to smilc 
again, and said he would make them "peautiful by polishing dem vid proken glass ven he got back."

It seemed a long time waiting for the potatoes to get done, and while we were wondering what to do, Little Trudy said:

"No flowers on picnic table."

Then we all thought how much prettier the table would look with flowers in its center.

Kate Hood ran off one way and I another. We neither of us thought of Little Trudy.

I knew how hard it was to find flowers in the woods, since they have chosen to grow in the meadows and along the roads, and I was so afraid of not finding any that $I$ ran in just the other direction from Old Adam than we go usually. I went very fast and only stopped when I bumped into a great many beautiful flowers. I had never seen any like them before.

Each flower-head stood up on a stalk of its own, almost as tall as $I$, and in these round heads a great many little lavender flowers grew together. The green leaves of the plants were slender and pointed, and very good to smell.

I knew Tommy was cross already because Herr Wilhelm Fritz had taken the Clammy Azalea wood to whittle, but I didn't care if I made him crosser. I picked a whole big bunch of these beautiful flowers and ran back with them. Kate Hood was already back, and had only found some ferns. 


\section{THE PICNIC ON OLD ADAM 183}

The potatoes weren't done, and when Tommy saw the flowers I had he was surprised.

"Where did you get them?" he asked.

"Way down where I could see the road from the woods," I answered.

"They're called Wild Bergamot," Tommy said then. "I know another place where I find the flowers in bloom from now on until August. They're related to that little mint we have in sauce with lamb."

"This plant is much larger than that little thing," I said, " and much prettier." But then I smelt its leaves and they were very like mint.

"See how funny each of the little flowers in the heads are," Tommy said. "They are the shape of tubes, although at their ends they are divided like our two lips."

I told him there was a wonderful brown bug on many of the flowers when I gathered them.

He said he had seen that fellow and that it was just as fond of Wild Bergamot, and a beautiful relative of Wild Bergamot, called Bee Balm, as Ruby-throated Humming-bird was of Columbine.

"The potatoes are done," Philip shouted. And Herr Wilhelm began to help him and Tommy get them out of the hot earth. We all sat down on the rock around the table-but where was Little Trudy?

We remembered then that she had gone for flowers. We jumped up from the table and called 
and shouted for her to come back, while Philip ran down by the swamp and Tommy out by the road. I don't know where Herr Wilhelm Fritz went.

She wasn't hard to find this time, for Tommy had her in a few minutes, and then he gave his long "la, la," call so that the rest of us would come back.

"She was down there getting Bouncing Bettys," he said, when we were all around the table again.

Indeed she had brought back a bunch of Bouncing Bettys. These are pale-pink flowers, and grow more often about old houses and along the roads than in the woods and meadows. I think every child knows them, and knows too that they never bounce, although they are called bouncing. There are both double and single Bettys, and when I find them they are in little companies together.

We put the Wild Bergamot and Bouncing Bettys in the center of the table with Kate Hood's ferns all around them. They made such a beautiful bouquet that Herr Wilhelm Fritz never said a word about their being "old vild vuns," and Tommy kept still about vanishing wild flowers.

Philip said he'd give a toast. It was, "Our Flower Friends."

This was such a wonderful thing for Philip to do, who always says he loves animals better than wild flowers, that we began to laugh. I can't tell 


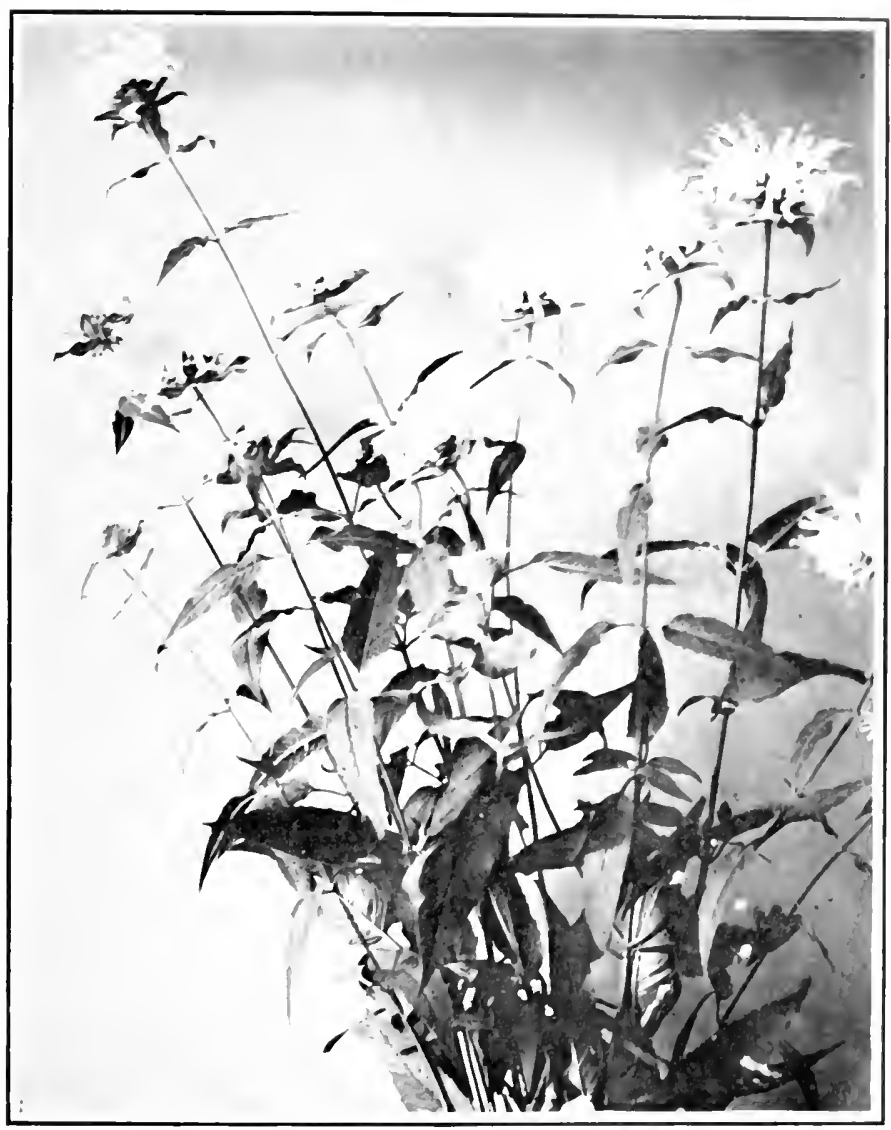

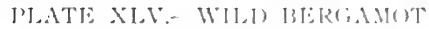




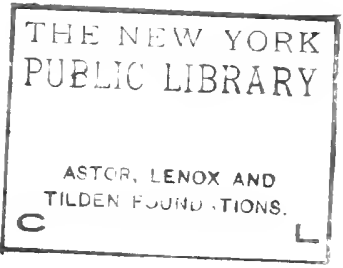




\section{THE PICNIC ON OLD ADAM 185}

when we would have stopped laughing and eating luncheon, if Peter hadn't come with a great bounce and upset the baskets.

Tommy had run away from Peter in the morning, and he had just found out where we were. 


\section{CHAPTER XXIX}

WHITE FLOWERS AND A MISCHIEVOUS FAIRY

Since the day we had the picnic on Old Adam, we have gone in the meadows and along the roadsides when hunting for wild flowers. Most of them now want to be out where the sun is brightest, and perhaps because they also like many people to see them. The little spring flowers that only peeped out in the woods were more shy. We really had to hunt for them. But I still love them and the woods best, even if Kate Hood tries to make me think the larger summer flowers are handsomer.

I know the woods will not look as they did in early spring again this year. The weeds have grown tall and bold, and the dead, dried leaves that covered the ground so crisply have blown away, and the tiny green ones that looked like crinkled tissue paper when they were unfolding are now so large and thick in the woods that they make it like a dark forest.

Just as I was thinking about our woods and that there is not a single flower on Old Adam, I remembered Francis's story about the Ghost-flower, and thought the time to look for it had come. Grandmother was taking her nap. I found my hat and ran out in the woods. 


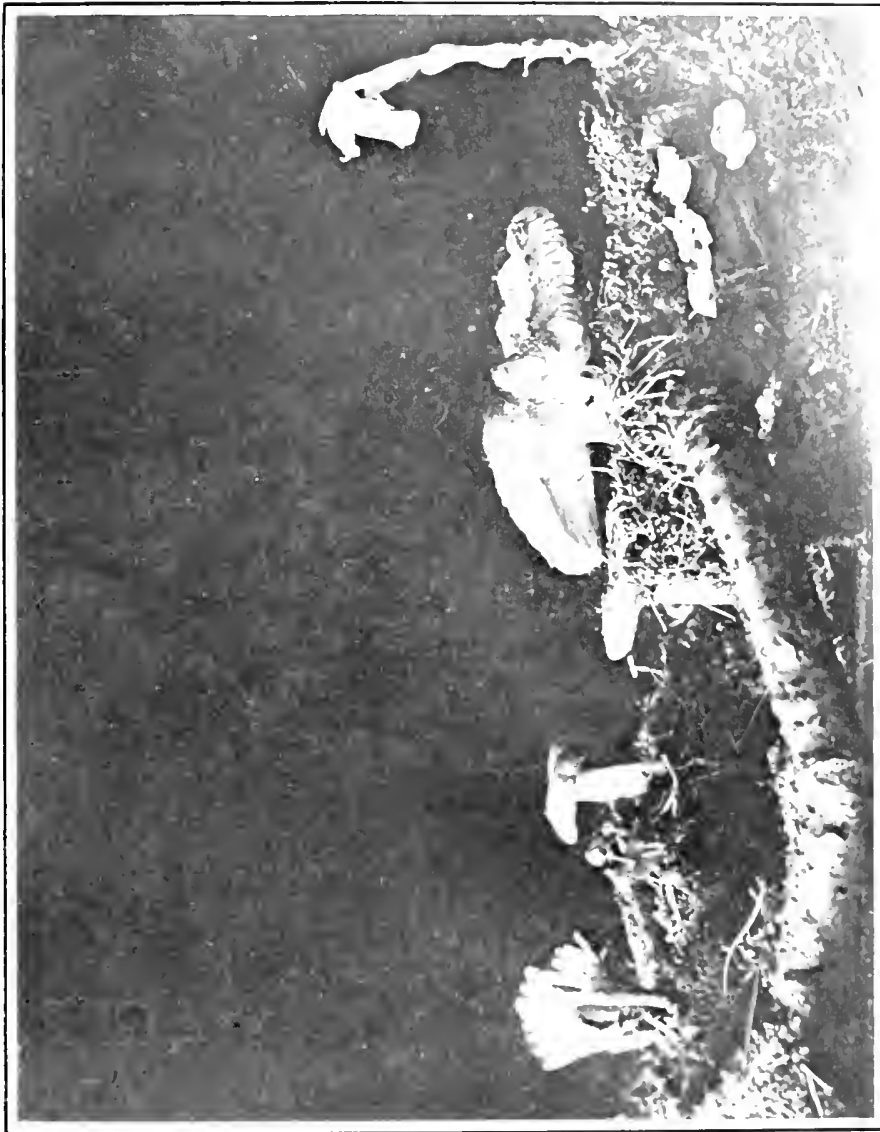

$\vdots$
$\vdots$
$\vdots$
$\vdots$
$\vdots$
$\vdots$
$\vdots$
$\vdots$
$\vdots$
$\vdots$
$\vdots$
$\vdots$
$\vdots$
$\vdots$
$\vdots$
$\vdots$
$\vdots$
$\vdots$ 

I didn't know where to look for this flower. If it were like a ghost, it should be large like a grownup person; but Francis had said it was small and looked like a pipe. This seemed odd. I searched over the ground for something like a ghost and like a pipe. In a book once I saw a picture of a ghost, although it was not a real one.

Our own woods are the only ones that Grandmother likes me to go into alone. They are not far away and when it is time for me to change my frock Wilhelm Fritz takes the megaphone and calls, "Home, Sveet Home." He never will call anything but that, and he repeats it over and over again, until he sees me coming. Once I came from another way than the woods and was close beside him when he gave a loud shout in the horn. He said, "Dat vus not a goot joke nohow."

I didn't go far in the woods when I went to look for the Ghost-flower, nor near Old Adam. I came very soon to an old $\log$, and close beside it I saw a young robin. It had hurt itself, for whenever it tried to fly it dropped right down. I sat on the $\log$ and took it in my lap. The mother bird was up on a bough and made a great noise, giving its loud chirp, but that was no help to the hurt birdie. When I put it on the $\log$ to see if the old bird would stop chirping, it dropped its head over and looked more sick than ever. I thought I would walk around a little and see what the mother bird would do, or else I thought I'd hide. I went be- 
hind a tree and stooped down on the ground. In front of me something made a white gleam, like a little piece of paper. I leaned over to see just what it was, and as sure as anything. I saw a little flower, white like a ghost and shaped like a pipe. Of course it must be the one Francis had told the story about.

Before I took it up from the earth I looked around to see if there were any others. Instead I spied a great Pyxie stool not far away, as Tommy calls mushrooms, with a beautiful bright, red top, and quite near it were two little baby ones also with red tops. Then I saw another curious white thing. It looked like the piece of coral Sallie's father once brought her from Mexico.

Surely this was a wonderful part of the woods for finding flowers. Here things were more like the early spring. There were no weeds, and the earth was not covered with all kinds of green leaves. I soon found some other white flowers, prettier even than the Ghost-flower.

Three of them grew together, on little plants that stood up so stiff and straight they made me think of trees, although they were only half as tall as a lead pencil. Pretty white lines ran through their stiff green leaves, but really the prettiest part of all was the sweet-smelling flower. It hung over from the top of the stem, and was as white as wax. The petals were curved back. I don't know why, but it made me think of fairies and the flow- 
ers they would love. Most of the plants had but one flower, although one had three that had turned to brown, so I thought it was getting ready to make seed.

I was so pleased to find these flowers that at first I didn't look far enough away to see another little one that was quite different. It was only a white stem with the queerest little flowers growing out from its sides near the top. These were brown and white, with purple dots in the center of the white, and they had a sharp look like some insects getting ready to snap. I felt sure these little flowers were very rare. I dug a stick down into the earth about them, so that I could take them up without harming their roots, for, of course, Tommy would want me to fetch them back and plant them in that very spot again. The fern that grew by the queer flower was the one we call Spleenwort.

When I had these two new flowers in my hand, I went back for the Ghost-flower and took it up and wrapped it in a large Wild Raspberry leaf. The little sick robin had gone away, and I couldn't see the old bird anywhere.

Just as I got back to our house Herr Wilhelm Fritz was taking out the megaphone. 'Tommy was in the library with Grandmother, and when I came in with so many treasures in my hand, Grandmother said I was more of a witch than the one Fräulcin had told her about. 
"Isn't that Francis's Ghost-flower?" I asked Tommy.

"Yes, and it's also called Indian Pipe," he said. "See, it has no real leaves, but these scaly things on its stem take their places, and no doubt it likes them just as much as fishes like their scales."

While he touched it a tiny round bug, as white as the flower, crawled out on his hand.

"It must be the special bug for this flower," Tommy said," and it is the same color as the flower, so that other bugs won't see it and eat it up. Let's put the Indian Pipe in water. If we handle it much it will turn black. I think it's for this reason that some people call it Corpse Plant."

The other little wax-like flowers, Tommy called Prince's Pine, or Spotted Pipsissewa.

"They have relatives," he said, "with fleshcolored flowers, whose leaves have not these white lines. They don't bloom until later."

Tommy thought I need not take either the Ghost-flower or the Pipsissewa back to plant in the woods, as from now on we would find more of them. He didn't know the name of the queer flower; neither did Grandmother, nor Herr Wilhelm Fritz. We have pressed it in between thick blotting papers and are saving it until Professor Bonn comes again. Tommy thinks I may be a discoverer.

In the evening Grandmother said I must surely tell the Ghost-flower story. Tommy and his 


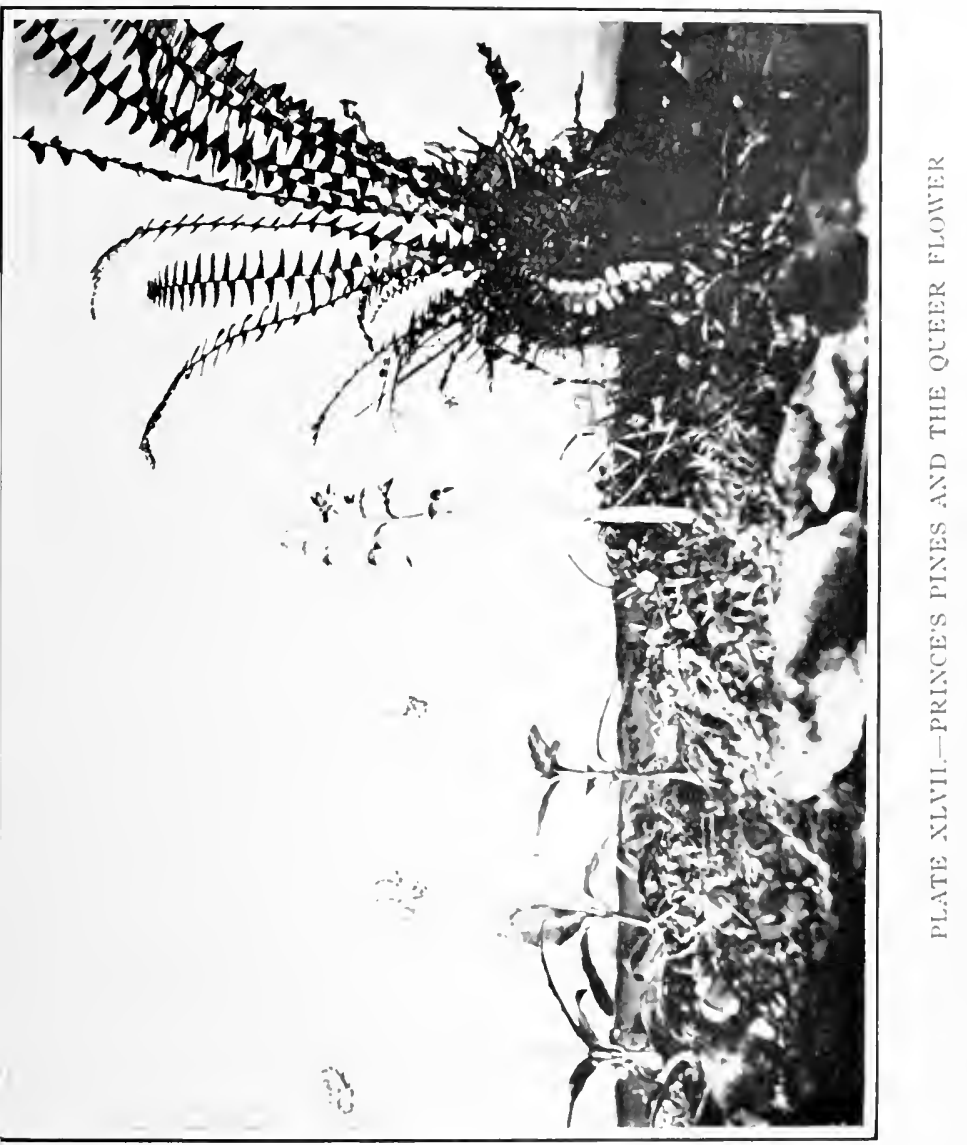




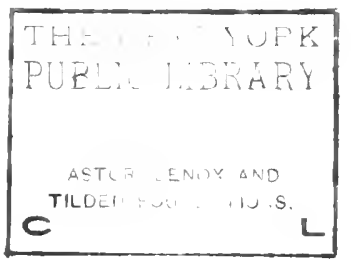


father, Philip and Grandmother were all in the room when I began.

"It all happened long ago when flowers had tongues, and fairies had not been frightened away from the carth. There was then a beautiful young fairy who used to come each evening and sit in the woods and sing. She didn't always sing: sometimes she danced, and sometimes she sat on Pyxie stools and pushed the toads away with her toes. She was the most mischievous of all the fairies, and she loved to tease the flowers and birds.

"Once an old crow that had hurt his wing was resting on the ground, and up the fairy jumped on his back. The poor crow couldn't shake her off and how he was ever to fly home with his hurt wing and the fairy on his back he didn't know. But when she had teased him until he nearly lost his wits she got off of her own accord.

"Some days she used to come to the woods dressed exactly like Columbine, and nod and jump around the rocks. This made Columbine angry, for Ruby-throated Humming-bird would $\mathrm{Hy}$ about her so much. Other days she dressed herself like Wild Rose, and danced so gracefully that Rose just pined to leave its thorns and leaves and dance too.

"She used to pick the flowers and wear them for caps and slippers and she made petticoats out of their petals. All these things made the flowers 
very angry, and they put their heads together to find out how to stop her mischief.

"A rabbit whose ears she had boxed gave them a bit of advice: 'Scare her,' he said, 'scare her; when I'm frightened I lie right down and am not a bit mischievous.'

"The flowers thought this advice was very sensible. They whispered to the earth, and to the wind, and lifted up their heads to the sun, for all these things make the flowers grow, and begged that a flower might come dressed like a ghost to scare the mischievous fairy away from the woods.

"It was growing late one day and many flowers were thinking about sleeping when along tripped the mischievous fairy. She was dressed like Meadow Lily and began to make fun of the flowers because they always had to stay in the same places. Then suddenly she gave a frightful scream. It was so sharp and piercing that the flowers lost their tongues that very minute, and the mischievous fairy and all her people forever left the earth.

"The reason she gave that scream was because a little flower, white as a ghost and shaped like a pipe, had sprung up in the path before her." 


\section{CHAPTER XXX}

FINDING ODD FLOWERS

There is no one like Tommy for finding odd flowers, and knowing all about them. He is still troubled though about the queer one I brought from the woods, and which we have pressed, because there is nothing like it in any of his books. Professor Bonn has gone to Europe for awhile, so it may be some time before we can even find out its name.

To-day we went to the woods, so that I might show Tommy the very spot where it grew, and because we hoped to find another of the same kind. Tommy could scarcely believe that it grew there all by itself, for he thinks its seed must have been sown by another plant not far away.

We passed the log where the sick robin had been, and I showed Tommy the two Pipsissewas I had left and the place where the Ghost-flower grew. We saw the very hole from which I had taken up the queer flower. But although we looked and looked all around, we could find no others that were the least like it. Tommy fecls almost sure that I am a discoverer.

"Did you see this Rattlesnake-weed when you were here?" he called. 
I ran to where he stood. He was quite close to the Spleenwort Fern, near where the queer flower had grown, and there surely a little yellow flower was open. I had not seen it before. The stem the flower grew on was fine and tall, and branched like a pitch-fork. It looked like a bright yellow daisy. The petals were shaped like small straps, although there was no round center of tiny tubelike florets. There was only a single flower in bloom, although, from the buds on the stalks, we knew that others were getting ready to open.

On the stem we counted two leaves, but more curious ones were about it where it touched the ground. They were quite large, with fine hairs around their edges, and the thing that made them look different from any other leaves were the deep purple veins running through them.

"It's called Snake Plantain, and Hawkweed, as well as Rattlesnake-weed," Tommy said, " and it has a good many relatives, although none of them are half so curious."

I knew I should always remember those strange leaves, hugging the ground so closely. I slipped my finger under one to see how it looked on the other side, and it was almost covered with black bugs. I put it down quickly.

"It isn't any more like a snake than other flowers," I said. "Why is it called Rattlesnakeweed?"

"Just because the country people think the 


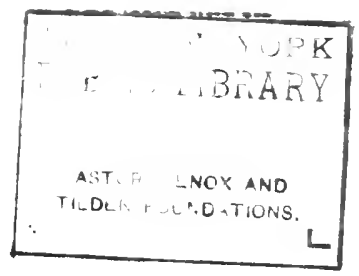


leaves look like a rattlesnake's skin. When they are bitten they run and get them to cure the wound."

"Do you believe they cure snake-bites?" I asked.

"Father doesn't," he answered.

I told him that was strange, because both he and his father were country people.

"There are different kinds of country people," he said.

"Do you mean Uncle Hiram's kind?" I asked. "Not exactly," he said.

"You mean country people like the man who sells chickens to Grandmother?"

Then Tommy nodded his head and said, "Yes, that kind."

I thought it would be a good idea for Sallic to plant the Rattlesnake-weed in her garden for vanishing wild flowers, as then the country pcople would know where to get a leaf quickly if they should happen to be bitten by poisonous snakes. Tommy said though that these plants were not vanishing, and that we should see ever so many of them from now on through the summer.

"They like to grow best in light woods," he said, " and people don't seem to pick them much."

Often Tommy says that it is more the early spring flowers that are vanishing than those which are coming out now in summer. When the winter is over pcople are often so glad to see green 
things that they rush out and pick everything in bloom.

Once Tommy knew a girl who thought wild flowers only grew in the spring, and she could scarcely believe it when he told her that the summer had flowers, and the autumn had others that lasted until Jack Frost came, and that even the winter had beautiful bright berries and leaves which kept green.

Tommy was disappointed not to find another flower like the queer one in the woods, but after we had hunted until we were sure none were there, we went down where the meadow is wet and almost swampy.

"We'll see what the sun has opened here," Tommy said.

I was looking every minute where I should step and trying to keep on the little hills of grass when I called out, "I smell something sweet."

"It's that Button Bush in front of you," Tommy shouted.

I saw then that near the water there was a large shrub with ever so many round, white balls on it that looked as though little pins with gold heads had been stuck in them. But these really were hundreds of little flowers growing in bunches as round as balls. I wanted one, but they were hard to reach, and Tommy shouted:

"Don't pick them; they would fade before you could get them home." 
I didn't notice anything odd about the leaves of this bush. They grew opposite each other on the stems, and underneath their color was more gray than green. There were no little sharp cuts, or points about their edges. After we had seen the Rattlesnake-weed's leaves these looked quite plain.

"How sweet the flowers smell," I said again.

"Honey-Balls is another of their names, or else Globe Flowers," Tommy answered. "I think they're even rounder than the globe."

It was such a wet place where we were that we got out quickly, and when we were only a little way from Button Bush Tommy spied another flower. St. John's-worts were near it, and tall Daisies and yellow Loosestrifes, and other flowers that we knew, but this one was quite different.

At first I thought it had too many leaves for so few flowers, and that it wasn't pretty. Tommy was delighted.

He said: "You never could guess its name."

"Blue-face," I answered, for the blue flowers that grew out on long stems from where the leaves joined on the stalk had a grinning look, something like the little queer flowers I had picked in the woods.

" Not right," Tommy said.

"Blue Tattle-Tales," I said this time, for they" looked as though they might like to tell things for spite. 
"Wrong again," Tommy said; " their name is Monkey Flowers."

"It just suits them," I said. "They do look like monkeys when they grin."

I picked a little bunch of them, and noticed that the stems were more square than those of most other flowers. We walked on then to another spot where they grew. When I happened to look at the blossoms in my hand to see if they were fading, every one of them had dropped off, and without the flowers the stems and leaves looked like weeds.

"Just like a monkey," I said.

" Carry a stalk home with buds on it," Tommy said, "and let them open in water."

I chose another then with buds, for most of these flowers had only begun to open, and all the way home I watched it closely.

"It stays around here until Cardinal Flower comes by the stream, and Joe-Pye-weed is in the meadow. Its blue looks pretty among the other flowers."

Tommy is like Little Trudy about blue flowers. Next to Columbine and Wild Rose he loves them best of all.

When we got home Mrs. Todd and Philip had come to see Grandmother, and to ask if we would go with them one day to a great rock very far away.

"Perhaps it is no larger than Old Adam," Mrs. 


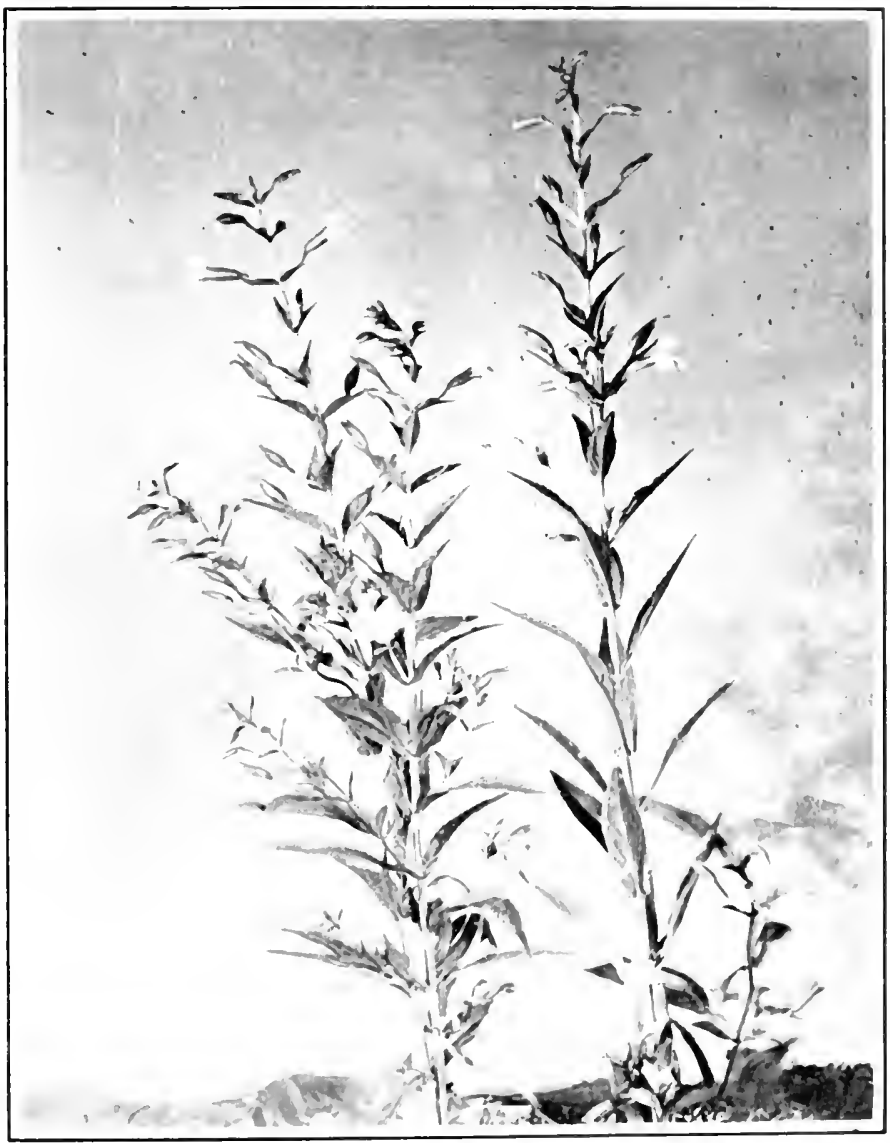

PLATE XLIX THE MUNEY LIAIER 


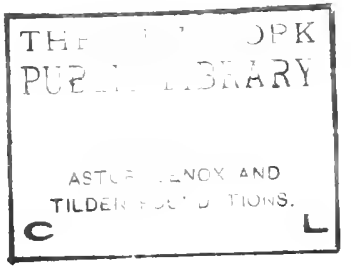




\section{FINDING ODD FLOWERS 199}

Todd said, " only it stands in a place from which there is a fine view."

We all wanted to go very much, and after awhile the day was set for Friday. 


\section{CHAPTER XXXI}

\section{MIDSUMMER}

To-Morrow Mrs. Todd is going to take us to Great Rock, so there is all to-day to be busy at something else. It is midsummer and the days are very hot.

When the postman came this morning he brought a letter from Sallie. In it there was a picture of her caught in a high bush of Sweet Melilot, or White Sweet Clover, which is the flower's other name. A little friend of hers had taken the snap-shot when Sallie wasn't looking.

Here Sweet Melilot has been blooming a long time, and we are glad Sallie sees it also at the seashore. It grows along our roadsides, and the air carries the sweet scent that comes from its leaves. Its little white flowers are something the shape of Sweet Peas, and they grow in long, slender bunches. The leaves are very like clover leaves, and at the top of each one there is a little notch.

One day when I went with Grandmother to see an old lady who sells peach ice-cream, there was a bunch of Sweet Clover leaves in the center of her table. I asked her why she made bouquets of the leaves instead of the flowers and she told me it was because she found they kept flies away. 


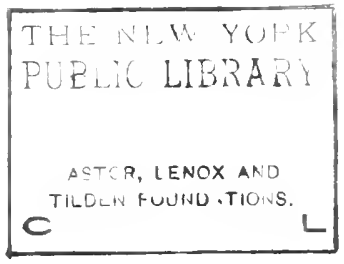


Tommy thinks the most curious thing about White Sweet Clover is that two of its leaflets close tightly at night and go to sleep, while the third one stays as wide awake as a watchman. Some time he is going to keep awake himself and find out whether it is the same leaflet that watches every night, for unless they take turns it seems very unfair.

Tommy's father says that many plants whose leaves are sensitive to cold drop them down, or close them at night, so that they may feel the cool air less than if they held them out flatly. This plan surely keeps Sweet Melilot just as warm and snug as the white woolly hairs do Hepaticas.

I wish I might watch with Tommy some night to see just how the Sweet Melilot puts its leaves to sleep. It can't rock them, or sing to them, as people do to children. Only when night comes I am so sleepy myself that I could never keep awake, no matter what funny way it had. If Sallie knew about these leaflets going to sleep I'm sure she would find out the way it is done. She didn't mind getting up with the birds to go out and see Bloodroot. When I answer her letter I will ask her if she knows why the White Sweet Clover puts its leaves to sleep.

Once Tommy went in the woods with his father at night, and he says they looked very different then from the way they do in the daytime. Bcautiful moths that he had never seen before were lly- 
ing about, and almost everything smelt sweet. 'A long way off he could see large, wonderful white flowers.

The reason Tommy and his father went in the woods that night was because Peter was lost: They hunted for him in some of Tommy's bunks and around Old Adam. But they couldn't find him, and it was not until the next day that he came home, and then quite of his own accord. Peter has acted badly lately. Tommy says he has secrets that he keeps all to himself.

There are flowers out in the woods now that could be seen at night; and I'm sure the people in a train would notice them if they passed by the wood's edges. Their name is Black Cohosh, or Black Snakeroot. This doesn't make things very plain, because they are pure white, and many of them grow in long narrow bunches on such tall stems that they make even Herr Wilhelm Fritz look short. Each little flower is tiny, and has a fluffy, pretty look, although its odor is rather horrid. The leaves are divided in something the same way as Maple-tree leaves, only they are larger and more cut.

When the woods are dark and these tall white flowers wave with the wind, they look like ghosts walking among the trees. They would make me much more afraid than the little Ghost Flower, shaped like a pipe.

To-day, when we were talking about flowers, 
Tommy told Grandmother that if he were not a naturalist when he grew up he would be a doctor. Then, he said, he could still love and study plants, and find out which ones would cure sickness.

Grandmother said then that once she had a gardener who used to make tea from Black Cohosh and drink it to cure his rheumatism. She wasn't quite sure though whether it did cure him or not, for he went away when Herr Wilhelm Fritz came to this country. She remembered that the same man used to hang up dried bunches of Black Cohosh in the glass-houses to keep insects away from the flowers.

Tommy was surprised to hear this about Black Cohosh, for his father once told him that long ago the Indians used it as a rattlesnake master.

I asked him if he meant that people used to wave long wands of the flowers at snakes and charm them, to pay them back for harming birds and rabbits.

"Oh, no," he said; "it only means that they used the plant to cure snake-bites just as country people do the leaves of the Rattlesnake-weed.

There are lots of toads in our woods, but nobody minds them. They hop away as fast as they hear any one. I am glad, though, that we seldom see snakes. Tommy thinks this is silly and of ten tells me that many of them are good creatures, for they eat worms and mites that would do the plants no good. Ladybugs and toads also cat up harmful 
little insects and Herr Wilhelm Fritz will never let us catch them to take away from his plants.

When I went to the edge of the woods with Tommy along the new road that has just been made, we wanted to get some Black Cohosh to dry and see if it would keep bugs away from Grandmother's flowers. We passed a place where there were many Starry Campions, such as Philip found the day he hurt his foot. It was early in the afternoon ther and many of them were still asleep. Of all the flowers it seems to me they are the laziest. Numbers of them don't wake up until four o'clock' in the afternoon, and although Tommy says they then stay awake until noon of the next day, it does seem very late to be opening.

I saw some bright specks of yellow just a little way ahead of them, so I ran on and found there another flower open quite near the Black Cohoshes.

"Do look, Tommy," I cried. "Do look!"

"It's Downy False Foxglove," he answered slowly, and making no more fuss than if it were a potato.

"Isn't it beautiful? " I asked.

Its leaves were very dark green, and the yellow blossoms were almost, but not exactly the shape of a funnel, because their large ends spread out into five little scallops.

"This one isn't as pretty as a relative it has with leaves like little ferns," Tommy said, "but I like 


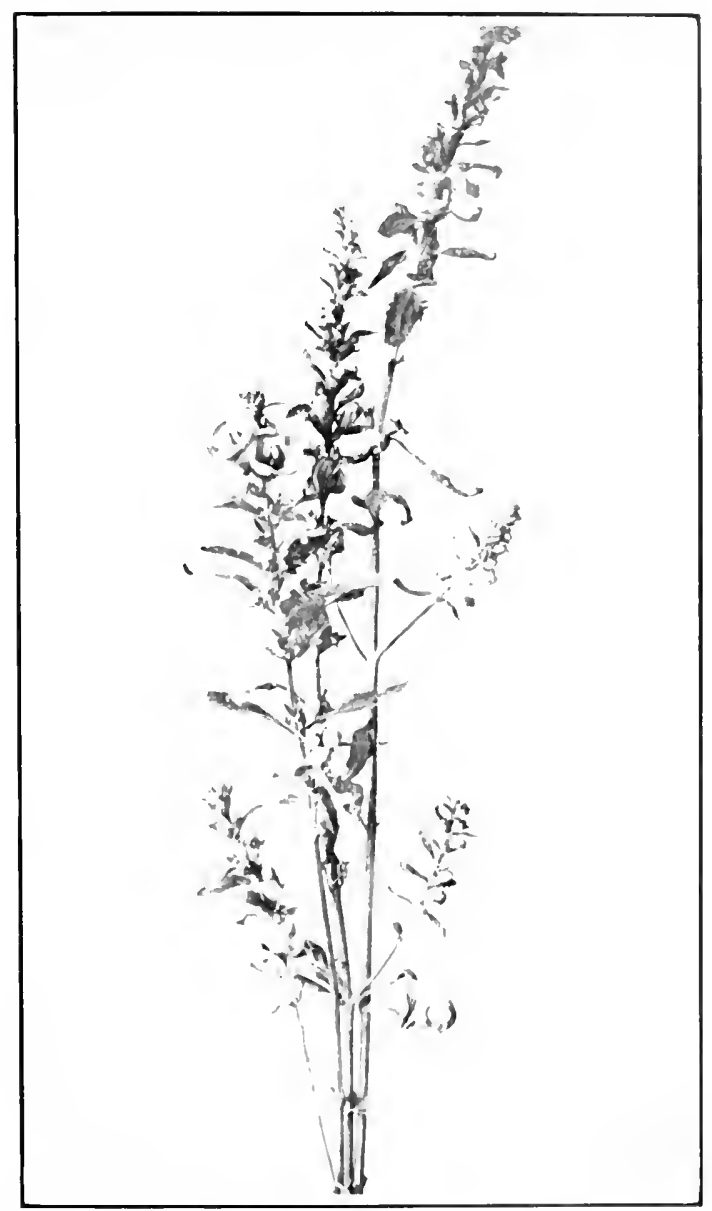

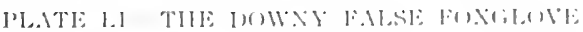




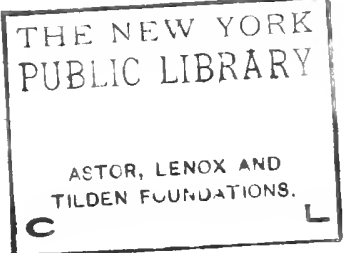


it better because it blooms earlier. The Fernleaf Foxglove waits until August to open, but here you see the Downy False one is in bloom while it's still July."

"How bright it makes the woods look," I said. Except Black Cohosh there was not another flower near.

"Nobody knows just why it's called Foxglove," Tommy said; "but father thinks the name was once Folk's-glove, because its other names have been Fairies' Petticoats, or Fairies'-gloves."

"I believe it's one of the very plants the mischievous fairy used to tease," I said; "the fairy in Francis's ghost story."

"If it is," Tommy answered, " it doesn't make much difference now. It looks just the same as it did last year and the year before."

We took a stalk home with a few flowers on and several buds. The flowers dropped off on the way, and the buds looked as though they might surprise us any minute by opening.

"They'll be beautiful flowers to-morrow, if you keep them in water," Tommy told me.

"So Foxglove is out," Grandmother said, when she saw what we had. "Let us enjoy each day then as much as we can, for the autumn will soon be marching down on us with a great army of flowers, and after that we must wave our handkerchiefs to summer."

"Why does that make you sad, Grandmother?" 
I asked, for I had heard her say that autumn in the country is very beautiful.

"Because Father Winter will then be just next door," she answered.

Tommy threw up his cap in the air and shouted: "That's skating-time!" 


\section{CHAPTER XXXII}

THE DRIVE TO GREAT ROCK

THE sun was very hot when we started on our drive to Great Rock with Mrs. Todd. We had three seats in the surrey, and I sat on the back one with Kate Hood and Philip. Tommy was in front with Barney, who is Mrs. Todd's coachman, and Grandmother and Mrs. Todd were in the middle.

Mrs. Todd said: "This is to be a drive and not a botanical excursion. The rock is a long way off, so we must go on steadily and not stop to look at every flower we pass."

Once Mrs. Todd had been to drive with Tommy and his father, and she teased them afterward because their horse went from one side of the road to the other, and stopped himself wherever there were many flowers.

As soon as we were a little way from Warley Towers Philip wanted to sing; but Grandmother said we must save singing until we were on the way home. Kate Hood said: "Let's tell stories," but we couldn't do that because Tommy was too far away to hear all we said.

"Enjoy the views," he called back to us. 
Just then a chipmunk ran along a stone wall we were passing. "Look, look," Philip and I shouted together.

"See his mate there," Tommy said. The mate was running up a tree.

For quite a little way then one chipmunk ran along the stone wall. Sometimes he dodged under, and in a minute came up again, but he always kept a sharp eye on us. Perhaps because he wasn't quite sure we would do him no harm. Kate Hood thought he was a red squirrel.

" Red squirrels don't have those two black lines running along their heads and backs," Philip told her.

He must have grown a little tired keeping up with the horses, for at last he sat up straight on the wall and let us get ahead of him, or else he wanted to go back to his mate.

"That's the largest chestnut-tree around here," Tommy called. "Just as soon as the frost cracks the burrs open we'll come and get the nuts."

Grandmother said: "It's one of the places I used to gather them long ago. The country is always the same."

"See that old Shagbark?" Tommy shouted. "Last year I picked up over a bushel of its nuts." We didn't wonder that this tree was called Shagbark, for its trunk all seemed to be standing out in narrow strips, as if the least little blow might shake them off. 


\section{THE DRIVE TO GREAT ROCK 209}

"Its bark stays like that even when we have hail-storms and thunder and lightning," Tommy called.

"Do you really get hickory-nuts under it?" I asked.

"Of course," Philip answered, as Tommy hadn't heard me. "Shagbark is another name for Hickory-tree." Then he shouted: "See that redwinged blackbird?"

Surely there was a bird as black as jet, with bright scarlet spots on his shoulders, flying across the wet meadow we were passing.

"Isn't he a beauty?" Mrs. Todd said, and then Philip told us he had seen the red-winged blackbird's nest, and that the eggs its mate laid were pale blue with streaks on them of dark purple. "It's so late in the summer now though," he said, "the little ones are pretty well grown, and they like to stay with their parents around the marshes and wet places."

Philip then gave a " chee-e-e-e-e," that sounded like the one the bird had made when he saw us coming and flew out over the marsh.

"That's the brightest bit of color we shall see to-day," Grandmother said. " My little girl here has not a ribbon so gay."

We were all glad when we came to a shady part of the road that had been made through the woods. Everything looked green here, and it was cool and still after the burning sun. 
Every step the horses took now was up, up; for the great rock stands very high, in a place almost like a small mountain. Mrs. Todd said: "When we come to the first gap in the woods we'll get out and walk."

Both Tommy and Philip had their jack-knives with them, and as soon as the carriage stopped they jumped out and looked about for walkingsticks. Mrs. Todd and I got down next, so there was only Grandmother left for the horses to pull. Barney walked along by their sides with the reins in his hands.

We came to one very steep place where we all stopped to rest. Tommy was ahead. He called back, "Hurry up!" So Philip and I ran along, even though we had just sat down on the bank.

"Here's something almost as bright as the blackbird's shoulders," Tommy said, when we caught up to him. Just in front of him I spied a single Red Lily. It grew all alone, and looked as though it had come to the very edge of the woods to peep out at the road. We all knew it was a Lily, although it didn't hang its head over, like the Meadow Lilies Tommy had seen by the side of the strange girl. This Wild Red Lily held its head up perfectly straight, and long, pointed leaves grew in little circles about its stem.

"It's the Wood Lily," Grandmother said, who was passing in the carriage. "It loves the woods quite as much as Meadow Lily loves the meadows." 
THE DRIVE TO GREAT ROCK 211

"Father calls it Wild Red Lily," Tommy answered; so we supposed it had two names.

Kate Hood wanted to pick it, but eren Philip told her it would fade before she could get it home. We left it and went on to see what else we could find.

We saw Foxgloves, and ever so many Milkweeds that had long pods on them; but nearly everywhere we looked the woods were plain green. When we stopped going up, we climbed into the carriage again and drove very quickly to Great Rock. Grandmother begged us not to go near its edge, for it hangs over the top of a high place, and if we should fall it would be far below into the valley.

It was real, real country up there. We couldn't see a single house, nor cren a cow. We saw meadows where grain was growing, and valleys and hills that stretched so far away they seemed to touch the sky.

Even Tommy had never seen such a view before, and he said he thought it more beautiful than the wild, moving ocean which he and his father once went to see. Then the wind blew his hat off. It went over the rock and caught in a poplar-tree a little way down. He was after it in a minute. He slid down to where the poplar grewand then climbed out on its branch and caught the hat. When he was there he was swaying orer the deep valley. Grandmother closed her eyes, she 


\section{THE DRIVE TO GREAT ROCK}

was so afraid he might fall. But he got back all right and said he couldn't think why we had all been so frightened about him.

We gathered some poplar leaves from other trees, because they were so pretty, and after that we were ready to go back. The Great Rock was so far from home we couldn't stay long.

Kate Hood made a wreath of the poplar leaves to put on Tommy's head, because he was such a wonderful climber. Philip wanted one too, as he had seen the red-winged blackbird. Then I wanted one, and Mrs. Todd, and soon even Grandmother had a wreath on her head. We came down from the high place much quicker than we had gone up. There was a brake on the carriage, and the horses went very fast.

"We mustn't forget that we are to sing," Philip said, when we were out on the road again. He now sat in front with Barney, and Tommy had his place between Kate and me. "Let's sing 'John Brown's body lies a-mould'ring in the grave." "'

He began and we were all joining in the chorus, when Grandmother stood half way up in her seat and asked: "Tommy, isn't that your strange girl?"

We were passing a meadow nearly all clover, and not far from the fence a girl was lying among the pink blossoms. She had straight hair which hung down by the sides of her face. I knew in a 


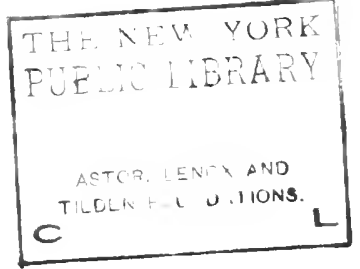




\section{THE DRIVE TO GREAT ROCK 213}

minute it was the girl I had seen in the Dogwood bough by the side of Old Adam.

She hadn't moved when the carriage came along and we were singing about 'John Brown's body,' nor did she even when we stopped so suddenly. Tommy was so surprised at seeing her that he forgot to answer Grandmother. He just nodded. Grandmother put her strong glasses to her eyes and said: "It's a soft pretty spot in which to rest among the clover. Perhaps if I try hard I may be able to think of the strange girl's name."

This time Grandmother didn't say one word about her being a spirit. Philip was the only one who said he saw nothing in the field but clover blossoms.

We didn't sing any more. The rest of the way we talked about the strange girl, and we were soon home. 


\section{CHAPTER XXXIII}

PHILIP FINDS FLOWERS BUT NO GIRL

The day after we had been to Great Rock, Philip started out to find the strange girl. $\mathrm{He}$ said he knew her hair hung straight down by her face, Tommy had said so often enough; he wanted to see the color of her eyes and to hear how she talked. Besides, Philip was disappointed that he had not seen her in the clover field when he had looked straight in front of him where Grandmother pointed.

When Philip left Warley Towers he was alone, and he counted on his fingers: "Strange girl was seen first in Secret Valley; seen again in Dogwood near Old Adam; seen again with Meadow Lilies, and last of all in clover field."

It was very hard for Philip to know which way to turn, for each of the places where she had been seen was in a different direction. Perhaps she goes where the wind blows her, he thought. He put his head up toward the sky and felt that the wind this morning was from the northwest, so he turned that way and it led him out by the old chestnut-tree, where the view from the hill is beautiful. Twice he had to cross the stream. Most of the way he was whittling a stick, and making calls to the birds, and looking over the fields as far as his eyes could see. 
In one direction he caught a peep of Little Trudy's white dress, and thought she was making mud pies. Far away he could see Grandmother in the garden talking with Herr Wilhelm Fritz; and when he went a little higher up the hill he could see Uncle Hiram standing by his gate-post. Peter was with him. But no matter where he looked he saw nothing of the strange girl. Then Philip thought the best thing to do was to sit down and wait for her.

A bush of Horsefly-weed, or Indigo Broom, was near by. He knew the look of its three smooth leaflets which are whitish underneath; and he liked its small, yellow flowers. Tommy once told us both that they were butterfly-shaped, although I remember them best because they remind me of Sweet Peas.

Such a hard wind was blowing that Philip could hardly hide himself among the small leares. Upon this hill the wind kept the soil very dry.

Philip really didn't care much for the Horseflyweed, although he thought it pretty, and saw it often in summer. He knew that country people made a sort of dye from it, and that Uncle Hiram sometimes had a bunch of its leaves tied over his horses' bridles to keep Hies away. Just then he noticed that the bush had more little bluish pods full of seeds hanging to it than it had flowers, and they had a sort of mist over them like that on the under part of the leaves. 
He thought he would go somewhere else to watch for the strange girl. He raised himself on his knee to get out from the bush, and just by his side, tucked snugly between two small branches, he spied a little nest. The eggs in it had been hatched long ago, even the little ones had flown away. Philip was sorry, for this made him think that the summer was nearly over, and that it would be a long time to wait for the next spring when birds would come again to build nests and lay eggs.

I must hurry up, he thought, or that strange girl will disappear with the summer, and I shall be the only one left who hasn't seen her.

He ran down from the high place to a stone wall. On its other side there was a field of corn, where he knew it would be useless to hunt for the girl. The walking between the rows is very bad, and once Philip had been lost in a field of high corn. It was when he was a very little boy, but he remembered quite well how hard it had been to find his way out.

It seemed as though the wind had sent him to rather a poor place to hunt for the strange girl. The hill now was on one side of him, and the cornfield on the other. He got up on the stone wall and walked along to where the next field crossed. There was little else in there but clover. Still he walked along and soon he came to a beautiful spot. 
EIderberry bushes stood up against the wall and their fruit was ripe. Philip picked one of the large bunches of berries which on the top are as flat as plasters and ate until his mouth and teeth were as black as if he had had blueberry-pie for dinner. But what made this spot so beautiful and different looking from the rest of the wall was because on the other side of the elderberry bushes, a vine with fleecy white flowers spread out along its top.

This may be the very spot to wait for that girl, Philip thought, and he sat down among the flowers, and snuggled in until the vine covered his lap. The sun was shining down on his head and was very hot, so he put on a little white cap he always carried in his pocket.

It wasn't a bit dull sitting there so long, as he had the flowers to look at, and could breath their sweet scent. The night before the rain had washed them clean, and many of them looked as though they had just opened. The name of this vine with bunches of white, sweet flowers is Virgin's Bower, or Wild Clematis, or else Traveler's Joy. This morning Philip thought the last name suited it best of all, as when he was a weary and disappointed traveler it made him happy to sit by it and grow cool.

The many little things sticking out from the flowers' centers gave them a fluffy look. The leaves, too, were pretty, and Philip saw how strong 
the vine was and how it reached out its tendrils like fingers and climbed.

It's as sure-footed as a donkey, he thought. Traveler's Joy was one of the first flowers he had learned to know when he was no older than Little Trudy. His mother then used to hang it in the house after its flowers had fallen, and long feathery ends were attached to its little seeds. These had caused Philip a great deal of wonder, because his mother did not think them pretty enough to wear in her hat, when he liked them so much better than ribbons and lace.

If that strange girl were sensible, Philip thought, she'd sit here on this wall, and not lie out in a sunny field of clover blossoms. But although he waited some time, thinking he might see her, he got up after he had eaten his fill of elderberries, and pulled himself free from the vine.

She's harder to find than a rare wild flower, he thought, and crossed the next field, and went back to where the plank is laid across the stream.

"Here are flowers, real beauties!" Philip cried so loudly that a little bird sipping in the stream looked at him and flew away. "If I'd have found that girl now, I would have brought her here to show her how beautiful you are. 'Jewel-weed,' that's your name, and you are like jewels. You hang on stems as fine as threads, and you are shaped like a lady's earring, or some pretty thing she dangles from her neck. I like your bright 


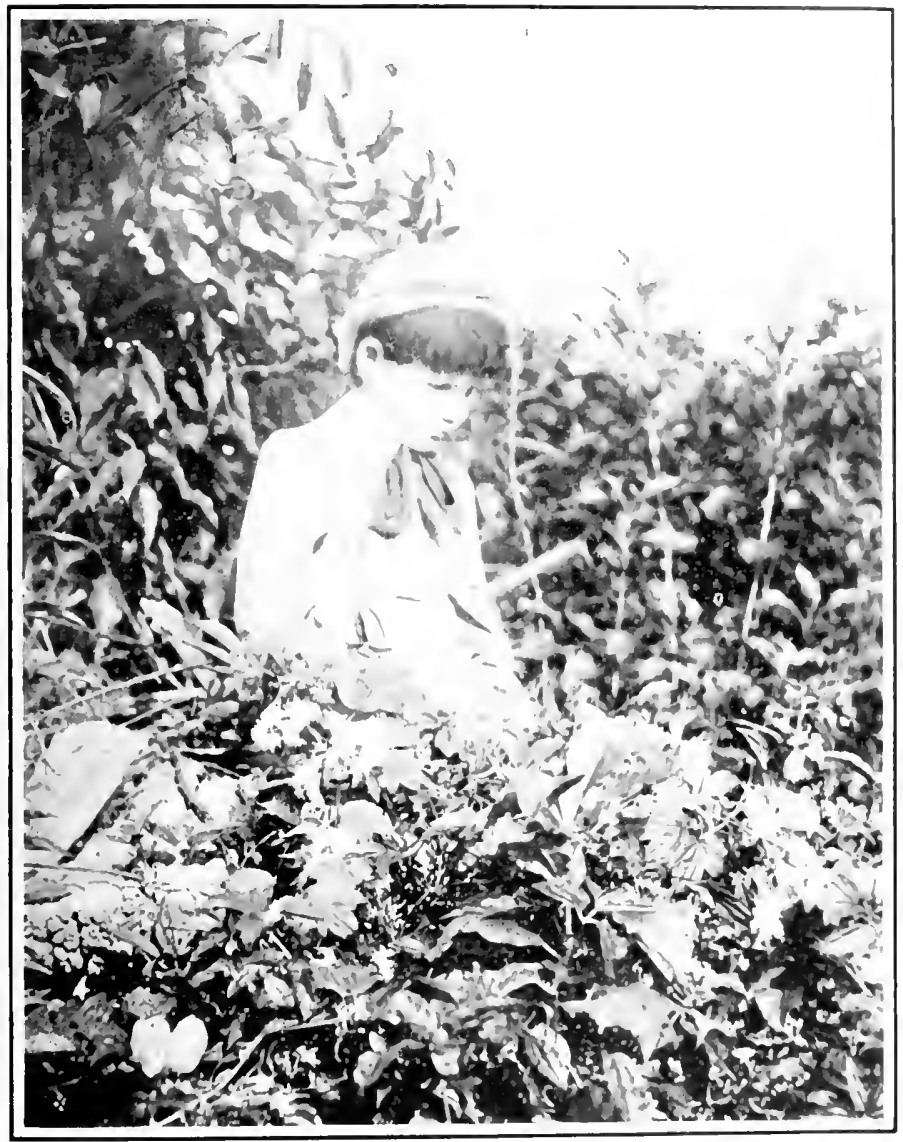

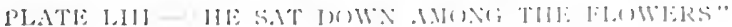




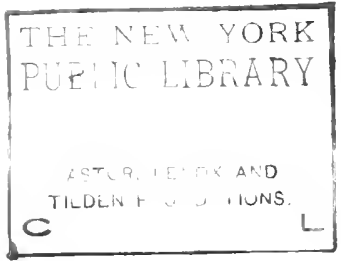


yellow color, and those dark spots that make you look as if you had been painted."

Pretty leaves hugged around the flowers. Underneath they were of a silver color, and bobbed up and down in the stream without ever showing that they had had a ducking.

"Silver-leaf, what a good name for you," Philip said. "You're much too pretty to be called Touchme-not."

He said this even though he knew that the Jewel-weed's pods could never bear to be touched. When they're ripe it's fun, though, to poke them with the finger, for then their seeds fly out just as straight as if they came from a pop-gun. Sometimes they shoot out so far that the next year Jewel-weeds come up a long way off from the one that made the seeds.

"Tommy says you're a weed," Philip talked on, " and that you have a way of choking other things that want to grow near you. I belicve myself that you have more than your share of this stream's bank. But I sha'n't scold you, even if you are a bad weed. I think you're almost as curious as the Yellow Lady's Slipper."

Philip hung a Jewel-weed flower in his buttonhole, and went on down the stream. He was getting nearer home every minute, and when he reached there he stopped and said:

"I haven't found that strange girl yet." 


\section{CHAPTER XXXIV}

\section{IN MISS AMELIA'S MEADOW.}

There are two ways of going from here to Miss Amelia's house. One is by the road, and the other is through the back meadows. When I go with Tommy, or Philip we choose the meadows. We don't mind climbing stone walls, and it's only on Uncle Hiram's fences that there is barbed wire. Grandmother and I always go by the road.

Since Kate Hood has lived there we have been to Miss Amelia's quite often. Yesterday, when we were as far as Uncle Hiram's fence, and Tommy was holding up the wire for me to crawl under without tearing my frock we heard some one shout, "Hey there, hey there!"

My heart beat very fast, and Philip, who says he isn't afraid of anything, grew quite white in the face.

"Hey there! hey!" we heard again.

"It must be Uncle Hiram," Tommy said, and soon we saw him coming along by the other side of the wall.

"What are you three thinking of doing in my pasture?" he asked.

"We're just crossing to go to Miss Amelia's," Philip told him. 
"It would be neighbor-like to stop in and see Uncle Hiram, either going or coming, wouldn't it?" he asked, and gave one of my curls a pull.

"We didn't think you wanted us," I said.

"Sometimes children don't know as much as dogs," he said. "Uncle Hiram's bark is worse than his bite."

He began running his fingers through his beard and smiling a little, so I said we could make him a visit then, because Miss Amclia didn't know we were coming, and that if we went there later in the afternoon it would make no difference. Tommy stayed a little bchind while Philip and I walked beside Uncle Hiram.

He lives all alone, and cooks the things he has to eat. Grandmother says he won't let any women in his house, because he doesn't know how sensible they are. We all followed him through the front door, and when we got inside Peter jumped up and began to make quite a fuss with Tommy.

"Uncle Hiram, what do you mean by kecping my dog shut up here?" Tommy asked. He was very angry, for Peter had been away from his home three whole days.

"Where are any doors shut here?" Uncle Hiram asked, and kept stroking his beard.

"You know he's my dog, and you should send him home," 'Tommy said.

"He'd come back again. I tell him he's a run- 
away every time he comes. He's just the sort of dog that knows when he's welcome, even if his master doesn't."

"Peter," Tommy said, " are you going to stay here with Uncle Hiram, or are you coming along with me?"

Then Peter got up from his haunches very slowly and walked over by Uncle Hiram. He lifted up his front paws and put them on his shoulders, and licked his face. We knew he was saying goodby. Afterward he walked over to Tommy. He knew he'd been doing wrong to stay away from home so much, for he had his tail down and looked ready for a scolding.

"If he comes here again and stays a day," Tommy said, "I won't take him back. He's yours to keep."

"Just as you say," Uncle Hiram answered, and he didn't seem to notice that Tommy was disgusted with Peter.

It was cool and shady in Uncle Hiram's house. I liked it there. He gave Philip and me lemonade and seed-cake. Tommy wouldn't take any. Uncle Hiram said to him, "No hard feelings?" as we were going away, but Tommy didn't answer. He hardly spoke a word to Philip or me when we were out in the meadow; but he kept tight hold of Peter's collar.

The tallest plant now in Miss Amelia's meadow is a Great Mullen. It's higher than any others 
about, and almost as tall as the Black Cohoshes that grew in the woods in July.

I don't call Great Mullen a new friend among the flowers. Ever since we found Hepaticas its leaves have been lying like rosettes in the grass. They are pale green and soft, and when I touch them they make me shiver a little as I do when I bite the skin of a peach.

Its pale yellow flowers grow on what looks like a tall stick coming up from the middle of the rosette, and this must be two ycars old before they peep out on it. Each flower then only opens for a single day. Afterward it fades and another higher up on the stalk opens in its stead. In this way the plant goes on blooming a little at a time all through the summer and part of the autumn. No one ever sees the whole of the Great Mullen's stalk covered at the same time with flowers. On days when only two or three blossoms are open, the stalk looks very tall and the leaves very large and coarse to uphold such a few pretty little flowers.

When we could get Tommy to talk, for he was still very cross about Peter and Uncle Hiram, he said he called this plant Mullen Dock, although it had really more names than he could remember, " not one less than forty."

Philip thinks this is because the Great Mullen has been a wonderful traveler, and christened with a new name in almost erery country. Its 
real home is in the Island of Trapsus, a place he can't remember in his geography, although he is sure it is there.

Tommy says when he grows up and becomes a doctor, he thinks he will give Mullen-tea to his patients. Even now Uncle Hiram mixes it in a drink for his sick cows.

We saw a pretty relative of Great Mullen close by in Miss Amelia's meadow. Its name is Moth Mullen. It is not exactly a new friend either, because it has been opening its pretty blossoms ever since Daisies came out, and I have seen it many times. It has the same way Great Mullen has of letting only a few flowers open at a time near the top of its stem.

The Moth Mullen's stem, though, is very slender and reddish, and bears small pointed leaves instead of large ones in a rosette on the ground. Most often we find the flowers yellow, but sometimes they are pure white, and when we are very lucky we find them pink. The stamens in the center of these flowers are covered with a soft, purplish wool. Indeed when we see this we know at once they are Moth Mullens.

The flowers that are open on the Moth Mullens' stems when I pick them usually drop off, but others come out from the shiny buds after they have been in water awhile. I love the Moth Mullens, and until I saw Tommy walk by them so proudly in the meadow, I thought he loved them too. 


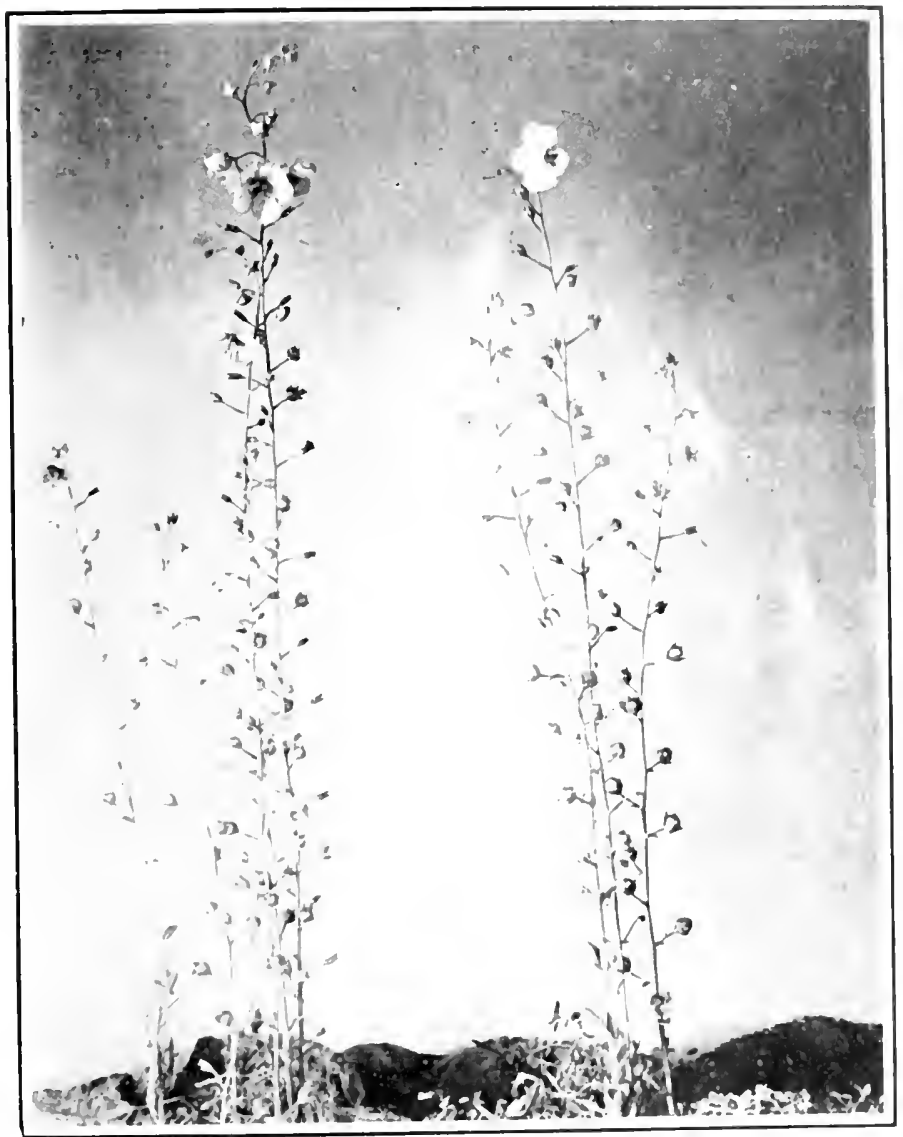

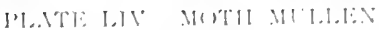




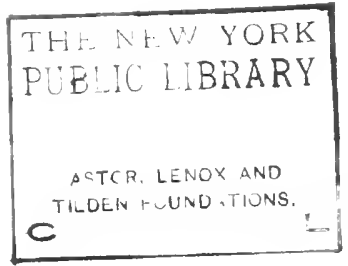

1 
"Why are they called Moth Mullens?" I asked him. "They look more like butterflies than moths."

"They keep moths and cockroaches away," he answered, and took a tighter grip of Peter's collar.

When we reached Miss Amelia's house we found that both she and Kate Hood were out driving, so there was nothing for us to do but go home. Tommy was a little more cheerful, and Peter seemed happier on the way back. He ran and jumped and wagged his tail for joy when Tommy let go his collar, just as he used to do.

The walking in Miss Amelia's meadow is very bad. Cows go in there and make great holes in the ground with their feet. Sometimes I stub my toe in them. Indeed if there were not so many wild flowers in this meadow it would be an ugly place to go. St. John's-worts are still there, and Monkey Flowers, and a few Black-eyed Susans and Buttercups. Other parts of the meadow now are almost covered with Simpler's Joy, or Blue Vervain.

Some of these plants grow much taller than my head, while others are not up to my knees. This is another wild plant that never lets all its flowers out at once. The Simpler's Joy flowers are smaller than either of the Mullens, and deep, purplish blue. They grow in bunches like spikes that stand up straight. Sometimes quite a number of the little flowers are open in each spike, but there is always 
a space at the bottom where seeds are forming, and another at the top which is all buds. It is only when they are nearly through blooming that the flowers come out at the very top of the spikes. "Let's take a bunch of Simpler's Joy home," I called to Tommy. Philip had left us when we came to the turn that leads to Warley Towers.

" All right," Tommy called back, " it isn't likely to vanish, by the look of this meadow."

"It's called Simpler's Joy," he said, " because long ago herb doctors cured so many diseases with it that it gave them joy."

"Perhaps it would cure us of colds better than castor-oil," I said.

Then Tommy began to explain that its leaves had to be made into a sort of tea for sick people to drink, and I knew he was no longer angry with Uncle Hiram and Peter. 


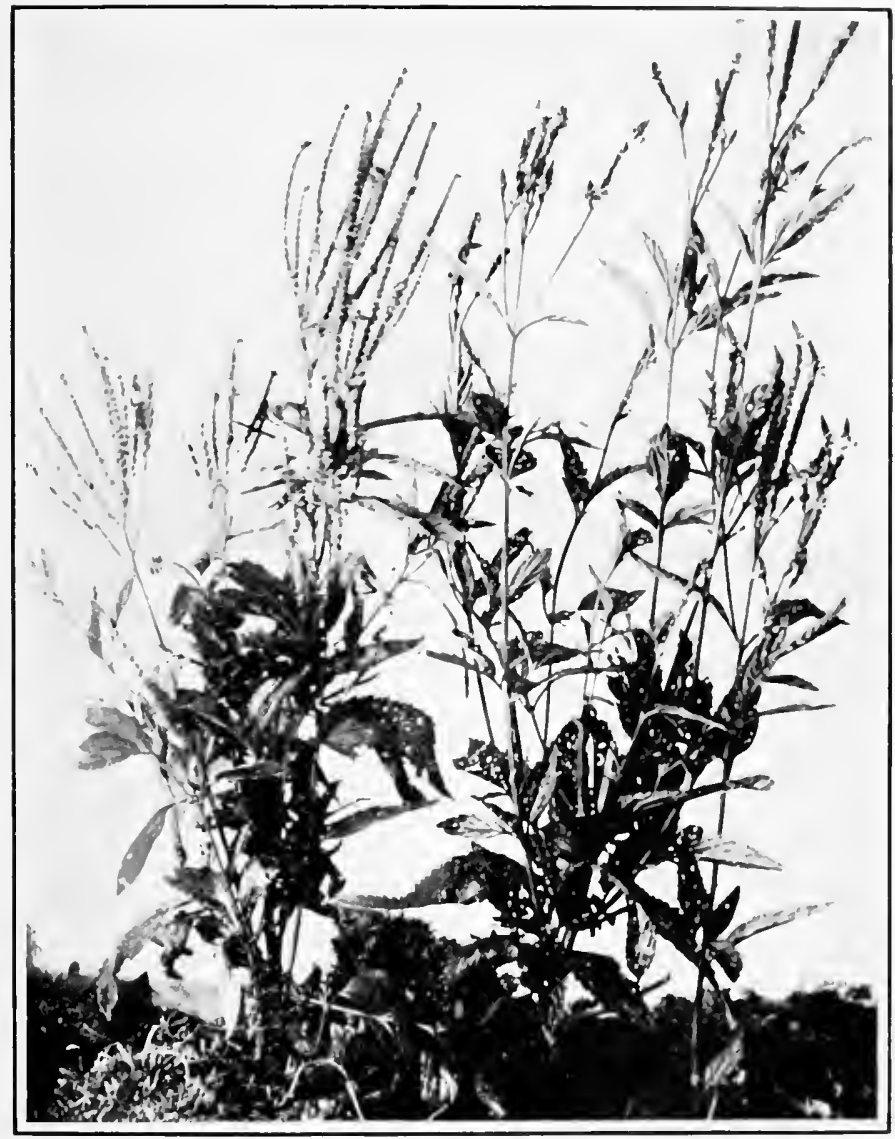

PLATE ルバーSIMU,ER'S Jル 


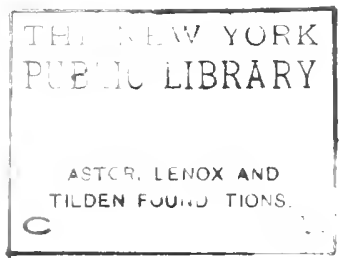




\section{CHAPTER XXXV}

\section{THE CARDINAL FLOWER}

When the first day of August came, Tommy was up very early, almost as early as Sallic was the day she went to the Bloodroot ridge. He gave a long whistle for Peter when he stepped out of the house, and then another, but the dog didn't come. Tommy then went to the kennel where he sleeps. He was not there. His bed was rumpled up in one corner, only it didn't feel warm as it does when Peter has been lying in it all night. Tommy whistled again, and called Peter as loud as he could. When he didn't come Tommy knew what had happened. He had run away again to Uncle Hiram.

Tommy felt so sad at finding this out that he almost forgot why he was up so early. He sat down and wondered what he should do. It was very different going out early alone, than it had been when Peter had sprung up to go with him, and barked and wagged his tail. Of course, Tommy knew that Peter was a jealous dog. Ife had even snapped at Little Trudy when Tommy petted her. He thought he liked it over at Uncle Hiram's because there was no one to interfere with him, and he had all the attention. Tommy began to talk a little to himself. 
"I've raised him from a puppy," he said, " and taught him about the woods and things until he knows almost as much as I do. He's the brightest dog in this county, but he hasn't a good heart. He bites little dogs every chance he gets, and he's always had a notion about running away. It's likely he'll stay with Uncle Hiram until he's tired, and he'll come and beg me to take him back."

A tear trickled down Tommy's cheek, for he loved Peter very much. The sun was growing bright, and Tommy began to remember it was the first day of August. He started off in the direction of the stream. Something made him glad it ran just the other way from Uncle Hiram's.

Most children are up early on Christmas and Fourth of July; but Tommy had a special reason for tumbling out of bed at dawn the first day of August. This was because the Cardinal Flower would then open. Of course, for such a wonderful flower as this Tommy had his own bunk. It was down by the stream, farther on than the Red Maples, and where the water runs a little over the meadow. He had not been down there for a long time, so he didn't know whether the flowers were even in bud. He walked rather slowly. He was still thinking about Peter.

He saw that the Button Bush had begun to make seeds, and that Monkey Flowers were all along the way. Then he noticed a Milkweed, prettier and more delicate than the common one which 


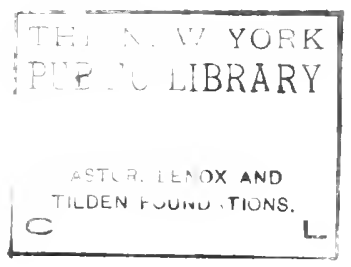


grows along roadsides, although he didn't like it so well as the Early Four-leaved one we had found in spring.

This Milkweed had deep crimson flowers, and long pointed leaves grew on its smooth stem. The flowers were just the same shape as those of all other Milkweeds, only they were larger. Tommy's name for this one is Swamp Milkweed.

With the Monkey Flowers and tall weeds and grasses that were nodding close by, the stream's side looked like a long bouquet creeping in and out by the water. Still Tommy walked on quite silently.

Some time before he came to the Cardinal Flower's bunk he knew it was in bloom. A tall bit of red like fire shot up among the greens. He forgot then about Peter and ran on. He didn't mind how wet it was, but jumped from one hard tuft of grass to another, until he came close up to the Cardinal flower.

"You're as beautiful as ever," he said, and before the words were out of his mouth another one of the flowers burst open. He saw how it undid itself as plainly as if it had been a box with a string tied around.

Cardinal Flowers grow together in long, narrow bunches at the ends of their stems. 'They are not large, but when many of them are in bloom the bunch looks like one beautiful flower. While Tommy watched them he was thinking hard. 
Each flower is like a little tube with a slit through its middle. At its end it is divided irto five pieces: two stand up and flare out, and the other three droop down. A Humming-bird was coming toward the flower, but when it saw Tommy it darted away. He hid himself then in one of the high swamp grasses close by, and waited without moving.

After a long time the bird came back. It held itself up on its wings in front of the flower, and ran its long bill in and out of the tube. Tommy said to himself: "Those three little drooping pieces in front make it easy for him to slip in his bill. What a feast he's having!"

A bumblebee came next. He couldn't sit down on the drooping pieces, nor on the other two that stood up. He buzzed around a little, sometimes getting quite close to the Humming-bird.

"Go away, old Bee," Tommy whispered; " you can't get the nectar, your nose isn't long enough to run down through that long tube. Why don't you go back to the Milkweeds and carry their golden dust?"

The bee still buzzed around, although once he went off and rested a minute or two on a large leaf. Then he came back and Tommy saw him light on the flower where its tube is slit. From there he could push his short bill in and get the nectar, and not come near the long stamens with the golden dust.

"You thief!" Tommy cried, and jumped from 


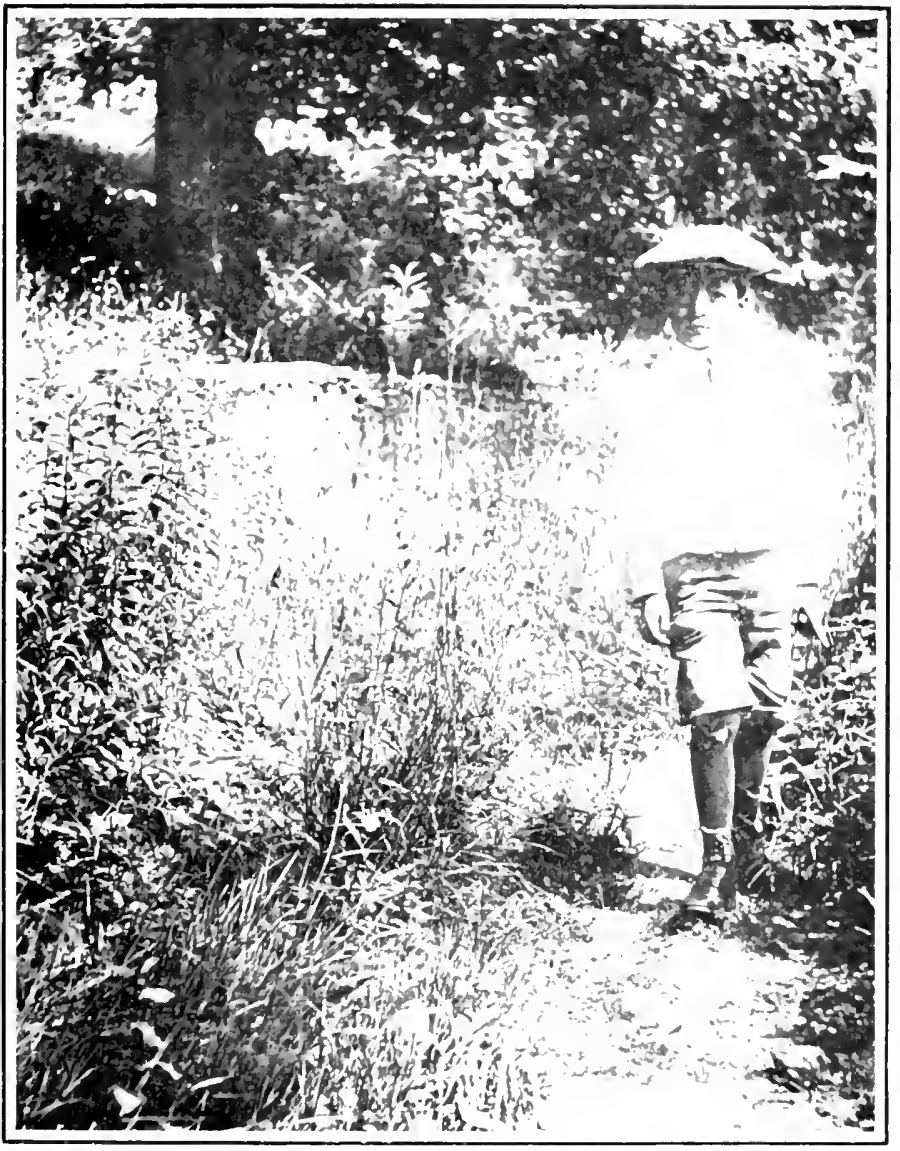

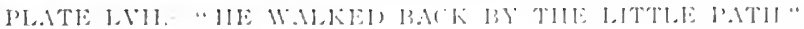




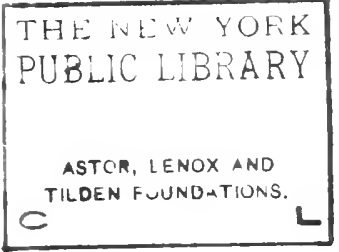


his hiding-place and frightened the bee away with his hat. "You won't have a feast without doing any work for it while I am here." $\mathrm{He}$ didn't notice that he had torn his stockings.

But the Humming-bird was frightened as well as the bee; and although Tommy sat down again and waited quietly a long time it didn't come back.

Higher up the stream Tommy saw a few other Cardinal Flowers that had burst open. He picked one of them to take to Grandmother. Afterward he began to feel hungry and wondered if it were time for breakfast. He walked back by the little path which we take to the village. It was shady that way, and the sun had grown very hot. He felt lonely without Peter, and hoped he would spring up from the kennel when he heard him coming. As he went along he whistled as loudly as he could, but he saw nothing of the dog.

After he had had breakfast he came over to show us the Cardinal Flower. It was quite faded, and although we put it in very hot water, it would not stand up straight again as Tommy had scen it by the stream.

Grandmother said: "It's a true wildling and looks best out in the meadow where things are green and sunny."

Its leaves are not pretty like those of Columbine. They even look more like weeds than those of Monkey Flower. I thought as Grandmother did, 


\section{THE CARDINAL FLOWER}

that it wasn't meant for the house any more than Herr Wilhelm Fritz's flowers would be able to grow by the stream.

"When I was a girl," Grandmother said, "the tallest Cardinal Flowers grew near a place called Indian Monument."

I asked right away if Indians were there.

"Not now," Grandmother answered, "but a long while ago they roamed through the woods near-by, and built the very monument which we must all go soon and see. There's a story about it also, but that I'll save to tell until we get there."

Afterward she talked with Tommy about the way Peter was behaving. 


\section{CHAPTER XXXVI}

ANOTHER PART OF THE STREAM

So many flowers bloom together through the summer that I cannot always find out which ones have opened first. I know Butter and Eggs were in the meadow and along the roadsides when Buttercups were here, and that they stayed to see Black-eyed Susans, and that a few of them are even here now when Loosestrife and Milkweeds are growing higher every day. Tommy thinks they will welcome the Asters and Goldenrods, and that they're really only afraid of Jack Frost.

I love these little yellow and orange flowers called Butter and Eggs, and which grow in long, narrow bunches. Their faces are so funny, and they seem to grin a little like Monkey Flowers. It is quite easy to see them far off in the meadow.

I suppose they are called Butter and Eggs because their pale shade of yellow is the color of butter, and their deep shade looks like the yolk of eggs. But this name isn't pretty, and I'm glad Sallie has found out about their other name being False Dragon's Tooth. Only a few people know how a dragon's tooth looks, and even fewer must know about a false one. I'm sure, though, that if a dragon had these little flowers set in his head 


\section{ANOTHER PART OF THE STREAM}

for teeth he would be terrible looking enough to frighten Uncle Hiram.

The flowers of Butter and Eggs end in long prong-like pieces, yet at their tops they flare out like mouths, and open and shut when their sides are squeezed. Philip used to play that he was a doctor and that they were his sick patients, and he dropped tiny seeds in their throats instead of tablets. Of course Tommy wouldn't play this game because he thinks it's silly. He doesn't care much for Butter and Eggs. "They are not even real Americans," he says, "but weeds that have come here from Europe."

I told him this didn't make any difference to me so long as they were pretty. He said then that his especial name for them was Yellow Toad Flax.

All summer long Tommy has walked by Butter and Eggs, just as though they were flower nobodies, and he never would say that they were beautiful, until one day when Grandmother had a little bunch of them in the window, and their fine pale green leaves and two shades of yellow shone in the sunlight. Grandmother asked him then how he knew they were weeds.

"Because they come up in waste soil and places," he answered. "They never hide away in dense woods like the Yellow Lady's Slipper, nor keep close to a stream like Cardinal Flower. You never have to hunt for them. They have no real bunks. They just grow anywhere." 


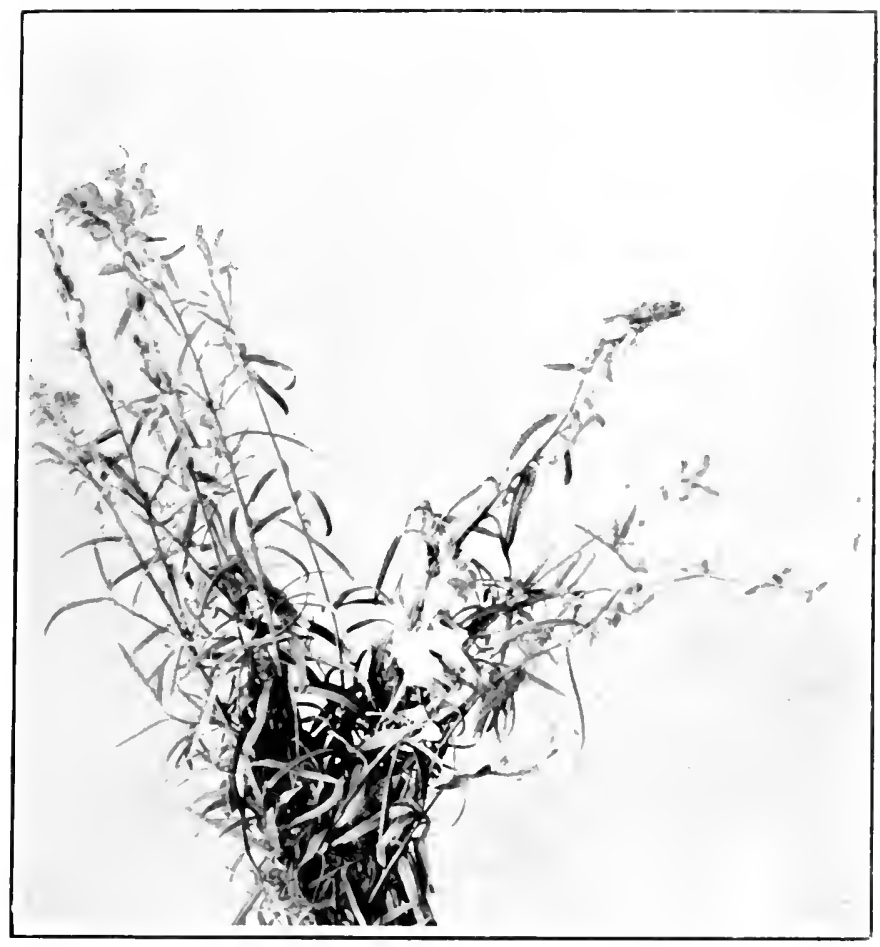

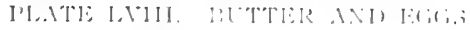




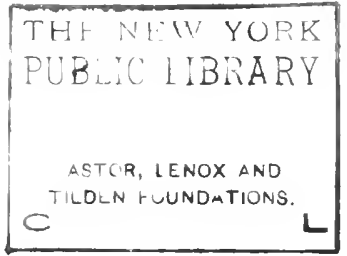




\section{ANOTHER PART OF THE STREAM 235}

Grandmother said she wished to know if a weed were a flower that had no real bunk.

"Not always," Tommy told her, but that he was very suspicious when they hadn't one.

I said I thought I should have to live in the country a long time before I would be able to tell weeds from flowers, because neither Tommy nor Professor Bonn had any rules to go by, and that even Herr Wilhelm Fritz was most perplexing whenever he talked about weeds. I don't know just what Grandmother means, but I have heard her say to Professor Bonn that it is sentiment which makes the difference between weeds and flowers, and that she only calls those weeds which are neither pretty nor useful. She thinks that her way is by far the best, for Wild Rose can then be a flower and so can Butter and Eggs.

Some plants that have been in the stream all summer are called Pickerel-weeds. But we have never once picked them. Their small flowers grow together in bunches, something the shape of spikes, and they are purplish-blue. Around their edges they have a ragged look. The one leaf on each plant opens near the top of the stem. It reminds me a little of a broad arrow.

Although Pickerel-weeds go on blooming all summer, Tommy has noticed that each of the little flowers lives but one day. As soon as it dies then another opens to keep the bunch fresh-looking. The reason we don't pick them is because they are 


\section{ANOTHER PART OF THE STREAM}

hard to reach in the water, and besides they have a rather horrid smell.

Close by them in the stream some pretty white flowers grow which are called Arrow-heads. I am often glad they are there, for we have no white Water Lilies nearer our house than Uncle Hiram's pond. Of course the Arrow-heads don't look a bit like Water Lilies, and they haven't the Lilies' sweet fragrance. But they are bright and pretty, and there is something curious about them. Their flowers grow in two groups of three around the stem, one above the other, and yet the flowers in these groups do not look the same. Those in the lower group are quite plain, for they are small and their dull little petals fall off early. But the ones in the upper group have large, white petals that are smooth and waxy-looking. These showy flowers are the male ones, and the little modest ones below are their mates. Tommy doesn't think it a bit strange that the little mates should be so much plainer than the other flowers. He says that the male Bobolink is much handsomer than its mate, and that this is true about other birds. He thinks things should be the same with flowers.

The leaves of Arrow-heads are even more like arrows than those of Pickerel-weed. One day I picked a few of them and a stalk of the flowers. The soft mud they grew in came up with the stems, and on the under sides of the leaves I soon saw many fat, black bugs. The flowers dropped off 
before I could get them home to Grandmother, and as the bugs crawled on my hand I made up my mind it was no more fun to pick Arrow-heads than it was to go in the water for Pickerel-weeds.

It is only because these two flowers are in bloom that we have been going to that part of the stream. Where they grow it runs through a different meadow than the one with the log and the bullfrog, and the ground there is mostly mud and full of holes. It is a squashy, soft place. Sometimes, just as I go to put my foot down, a toad jumps out and gives me a fright. One day I saw a little white toad there, and ever so many darning-needles flitting through the tall grass and about the Milkweeds. Then the crickets keep up the greatest hum in that meadow when the sun is shining. After all I like them much better than grasshoppers. These creatures hop on my skirts and hide in places where I don't see them until I am home and changing my frock before dinner.

There's been a grasshopper in my room for three whole days now. He came in with me the day I brought home the Arrow-heads. When he's on the window-sill I can see how ugly and awkward he is. He moves his queer, jointed legs very slowly, until I go to give him a poke out of the window, and then, quick as lightning, he hops back over my head into the middle of the room. His ways are so queer. I think I shall never be able to pet him as Philip does. Some day when he's 


\section{ANOTHER PART OF THE STREAM}

napping I mean to set a glass over him and then take him out and let him go on the grass again. Even now he must be hungry, for he has eaten none of the leaves I left for him on the windowsill.

The country is getting to look a little like autumn. Weed flowers have grown very high, and many plants have already sown their seeds. Tommy has shown me the trees where, before very long, we will gather the best nuts. But still the days are warm and many flowers are left, so I do not feel sad yet because summer is nearly gone and Herr Wilhelm Fritz has heard signs of frost coming in six weeks.

These signs are the katydids. They began to sing night before last outside of my window, and now they are keeping it up the whole day long as well. I should have thought they were crying if Tommy hadn't said so positively that katydids always sang. They seem to me to have arguments something like this :

" Katy did, Katy didn't; Katy did, did, Katy didn't, didn't did. Katy did, Katy did; Katy didn't."

They never seem to know very much about Katy or what she did and didn't do, but to-night, when I go to sleep, I suppose they will still be calling outside my window, "Katy did, Katy didn't, Katy did." 


\section{CHAPTER XXXVII}

\section{TO INDIAN MONUMENT}

THE day has come for Grandmother to take us to Indian Monument. It is a long walk there, but in the country it is much easier to go quite far than in the city. Here there are wild flowers to see along the road, and birds are singing, and ever so many different kinds of butterflies are visiting the flowers. Besides, here we can run and sing and jump along the road, while in the city it is only polite to go straight ahead.

Grandmother started in the carriage some time after Tommy and Philip and me, and we were to wait for her at the big chestnut-tree, where two roads cross. Just before we were quite there we heard her coming, so we ran quickly to the tree and were there first.

"Five minutes earlier and I should have beaten you all," Grandmother called, as Philip and Tommy helped her out of the carriage. "It's all on account of Herr Wilhelm Fritz that I have lost this race. He came to tell me the Nightblooming Cereus would open its flowers to-night. There are nine more buds on it than it has ever had before."

Tommy wanted to ask her then why she thought these flowers only opened in the night, but first 
we had to find out which road to take to Indian Monument.

"This time we will choose neither road," Grandmother told us. "We will go across lots."

She led the way then, and the horses waited under the chestnut-tree, where it was shady.

It was not often that Grandmother, or any one else knew a place that Tommy had never been to, and he kept wondering where she could be taking us.

"There's no Indian Monument in this field," he shouted, as we climbed over the first stone wall from the road. "Here there's only weeds, and rough grass; and in the next field there's wet ground, and Cat-tails, and Purple-spiked Loosestrifes."

We were already able to see the Purple-spiked Loosestrifes, for they covered nearly the center of the next field. These are wild flowers that grow very high. I had seen a few of them among the Milkweeds and Monkey Flowers along our stream, but there they had not half so wonderful a look as here, where they had the meadow nearly all to themselves.

"Isn't it beautiful! Isn't it beautiful!" we cried, "a whole field full of flowers!"

When we were close up to them we found that they were higher than our heads. Only Grandmother could look quite over them.

The flowers themselves are reddish-purple, and 
they grow along the ends of tall stems. They looked like purple wands that witches, or fairy godmothers, might wave. I thought, though, that when so many of them were together it was quite hard to see exactly how each stalk looked by itself. The whole meadow was more like a sea of purple water than a bed of wild flowers.

Why these flowers were ever named Loosestrifes is one of the secrets I am trying to find out this summer. They don't look a bit like the Bulbbearing Loosestrifes which Philip found the day he hurt his foot. They were yellow, and Tommy said they and all their relatives belonged to the Primrose family. But he told us the Purple-spiked flowers were members of the Loosestrife family, and not related to the others at all. I couldn't help thinking that either the Yellow Loosestrifes, or else the Purple-spiked ones should change their name, as it is surely not easy for children to understand why they are called by the same name, when they look so different.

"These purple flowers are not real Americans," Grandmother said, "like Columbine and Cardinal Flower and Goldenrod. They are European plants, although hundreds and hundreds of them appear to have settled very happily here, where they take up a great deal of soil and torment the farmers."

I said I supposed they liked to travel about, and see new countries, in the same way that Sallie did. 
"At least," Grandmother said, "there's more room for them to grow here than in the old country, for most of the ground there is taken up by people and houses."

We all could see that they were not a bit crowded in this meadow. Grasses grew with them, and a few Cat-tails, but no other flowers were in sight. Philip ran to get some Cat-tails, and just as he reached where they were, he saw Kate Hood walking through the Purple-spiked Loosestrifes.

"Hello!" he cried, and she called back, "Hello!"

"What are you doing out here?" he asked.

"Getting flowers!"

"Those purple ones fade," he called; "get Cattails, and come with us to Indian Monument."

Kate said she could do that, because Miss Amelia was away from home, and she had to amuse herself.

We didn't get over this meadow very quickly. It was wet in many places, and as Grandmother couldn't jump from one hard grass place to another, we had to make long curves around the field and keep where the ground was dry. The next field was very woody, and after we had been in it awhile we saw that picnic parties had had their luncheon there, and left old boxes and egg-shells on the ground.

"How ugly these things make the woods look," 


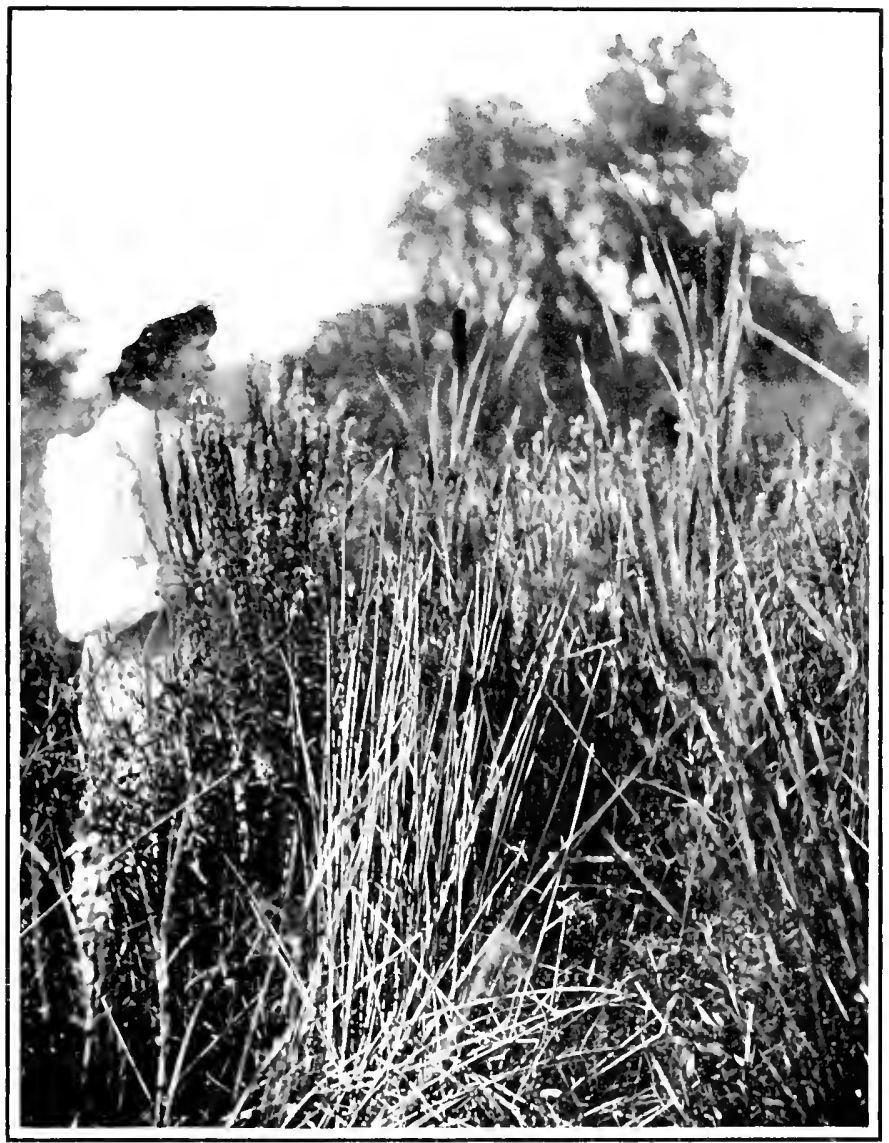

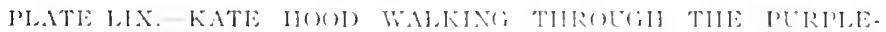
SIJKIJ I, SHISTRIFE 


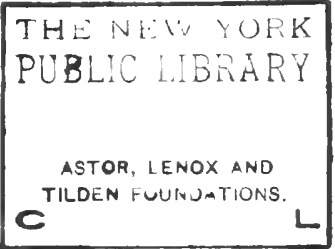


Grandmother said. "I think no one who loved the country very much would leave them here."

"Look," Tommy called, "here's a good plant trying to cover them up. It knows perhaps they don't belong to Mother Nature."

He wanted us to notice a great green plant like a shrub leaning over and hiding another lot of picnic rubbish. Its leaves were large with deep notches around them, and the flowers were pure white and something like Morning Glories. I thought both they and the big prickly pods which held the seeds were very pretty. I saw, too, that this was the very plant Francis had made a beautiful drawing from and sent it to Grandmother.

"It's called Jamestown-weed, or Thorn Apple, isn't it?" I asked.

"Yes," Tommy answered, "unless you want to say Jimsom-weed, like the rest of the country people."

Grandmother said: "You know, children, it is another European to which we extend hospitality. The Jamestown settlers brought it with them from Europe, because they used it in medicine. That is all long ago, and now it seems quite as much at home here as most of our own plants."

"It may be good in medicine," Tommy said, "if people know how to use it, but when they don't, it is very poisonous. One day I found Little Trudy drinking rainwater out of the flowers, and afterward she was sick. Father thinks it is one 
of the most poisonous plants, although the Jamestown-weeds that bear purple flowers have caused more harm than those with white flowers."

"Well," Grandmother said, "we need neither pick the flowers to find out how bad they smell, nor suck them to get poisoned. Let us just admire the way the plant makes itself useful by covering up rubbish."

We went on after this, Grandmother leading the way. Soon she took a turn in the woods, such as Tommy had never done, and before we had gone very far we came to an open space with a high ledge of rocks on one side. Just at the foot of them there was a pile of stones in something the shape of a haystack.

"That," Grandmother said, " is Indian Monument. I have heard many stories about how it came to be here, but I will tell you only the prettiest one that I know."

We sat around her on a soft bed of moss then, and she began:

"Once, long ago, there was an Indian maiden who loved a brave chief. He loved her also, for he thought she was as beautiful as the sun, and that her eyes shone like bright stars. But this young maiden and the chief both wore for their emblem a hawk, which meant that they belonged to the same clan, and therefore, according to Indian laws, they could never marry.

"One morning the maiden bade farewell to the 
chief. He was going away on a long hunt. The rest of the day she was very sorrowful, but when twilight came she gathered a great many wild flowers from these very woods. She twined them in her hair, and hung them in wreaths about her neck. At nightfall she climbed to the top of that cliff and threw herself over. She was very unhappy and felt she could not live without the chief.

"When her friends and relatives found out what she had done there was great grief in the tribe of the Hawk. The old and young Indians came from even a long way off and helped to bury her in the spot where she had fallen. Afterward a long procession marched in her honor along the top of the cliff. As it passed the place from where she had fallen, each brave leaned over the edge and dropped a stone on the grave. So the monument grew higher and higher as each one passed. Indeed, if we could count the stones to-day we should know just how many Indians there were in the maiden's funeral procession."

"What month was it when she died?" Tommy asked.

"The story didn't tell," Grandmother answered.

"Then we can never know what flowers she chose for her wreath," he said.

"I think it was spring," Kate said, "and she decked herself with the timid flowers that come early and are afraid to live."

"I'm sure it was summer," Philip said; "flow- 
ers are strong then and have courage. If she were timid she could never have thrown herself over that rocky cliff."

"I believe it was autumn after all," Tommy said, "and that her wreath was of red maple leaves. Only a few things stay the same when autumn comes, and many die."

I told Grandmother on the way home that I wished it might always be summer. 


\section{CHAPTER XXXVIII}

\section{FLOWERS THAT HAVE ESCAPED}

There are some flowers that Tommy calls "escapes." At first I didn't know what he meant, for flowers are never shut up in prison, and I could think of no other place for them to escape from. I have learned now, though, that they slip away from gardens, instead of prisons, which makes it quite easy to understand. Perhaps the flowers that escape get tired of living in gardens where they have to stand close to others which they may not like, and where they are always being picked for bouquets. So when they feel this way they send some of their seeds over the wall, and the next year a little company of their children springs up outside the garden. The next year these outside ones send their seeds still farther away, and so things go on until the garden flowers get far out in the meadow, or even into the woods. Then Tommy looks at them in the wise way that Philip calls "three-quarter," and says, " escapes."

Once Philip and I planted a Tiger Lily out in Miss Amelia's woods, and showed it to Tommy. We did this because we wanted to fool him into thinking it was a real wild Hower. He looked at it for a second or two, then lifted his head in the air as though he were sniffing something, and said: 


\section{FLOWERS THAT HAVE ESCAPED}

"This Lily is a great traveler. It has come from the garden at Warley Towers."

Neither Philip nor I smiled; we were too disappointed.

Another time we were on our way to catch bullfrogs in a pond back of Uncle Hiram's. We wanted them for Herr Wilhelm Fritz to put in his winter water garden, for there they eat little insects which might harm the flowers. Usually we catch them with hooks that are covered with red flannel. As soon as the frogs see these gay things bobbing up and down on the water they think they are wonderful flies, good for them to eat. They open their great mouths to snap them in, and then of course just what they don't expect happens. The hooks hold them tight enough for us to pull them up and Tommy unfastens them, and puts them in a tin pail full of water. He is always very careful to slip the cover on quickly, or they would hop out. Of course we never try to catch the bullfrog that sits on the log in the stream. He is a pet. Grandmother thinks we are more fond of him than he deserves.

The last day we started out for bullfrogs, Philip and Kate Hood were with us, and Philip said he knew a short cut to the pond. We went across a field that was very swampy, and then into one that was dry and had a little hill in the middle. There were a good many trees in this field, and my dress often caught in blackberry vines. After we had 


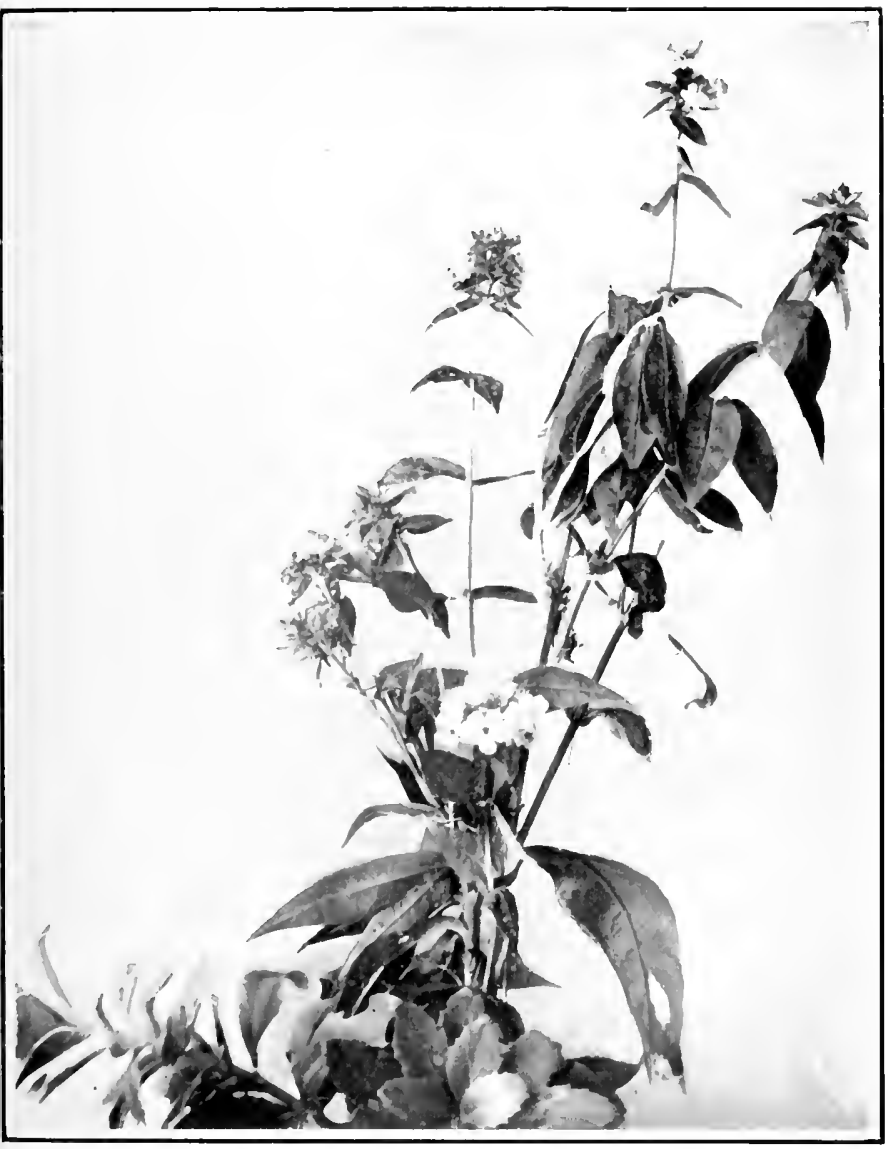

I'LATE LX-WILD I'IIUX AND RLBBER PLANT 


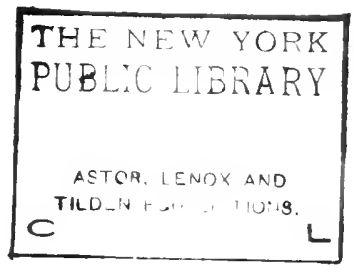


passed through the second clump of trees we all shouted out to see so many pinkish-purple flowers.

They were round looking flowers, and each one had five thin petals. I noticed that they grew at the top of tall, straight stems with many leaves on them, which were long and pointed at their ends. There was a sweet fragrance about these flowers, and I thought they would make a beautiful bouquet for Grandmother.

"How pretty they are," I said to Tommy. "They look like Herr Wilhelm's flowers."

"I'd like them better if they had a more wild look," Tommy said. "It's hard sometimes to tell these Wild Phloxes from the ones that do grow in gardens."

"Is this flower a Phlox?" I asked.

"Yes, Wild Phlox is its name, and it's related to the Ground Pink that comes in early spring. Those flowers were the same shape, only smaller, and they just lifted themselves a little way from the ground, because the little Ground Pink grows by creeping. Don't you remember we saw them in April on Wild Rose's Highway and that the flowers were either white, or pink, or purple?"

I said I did remember, and that I had thought it wonderful to see them spreading a carpet of flowers on the ground. I remembered also that they came before Columbine.

Then I didn't know how different flowers can make the same places in the country look. The 


\section{FLOWERS THAT HAVE ESCAPED}

highway seemed like some other spot when Ground Pink was in bloom than when Wild Roses and Wild Strawberries were covering the ground. That was all early in the summer, though, and I was still surprised at everything. Now I am more used to things here, and even Tommy thinks I have learned a great deal in one season. When I go back to the city I'm sure it will seem very dull.

Close to one of the Wild Phloxes a Rubberplant was growing. Its leaves looked bright green and fat, as they always do, and any one could have told them from the Phlox leaves, even if they hadn't had little notches all around their edges. I picked a good many of them, for I wanted to pinch their undersides until the skin was loose, and then to blow them up into little bags.

Tommy can't understand why all girls like to make bags of the Rubber-plant's leaves. He says they are no use after they are made. The reason really is because it's fun to blow them up without their breaking, and because it's something that can't be done to other leaves.

"Does the Rubber-plant ever have a flower?" I asked Tommy.

"Of course," he answered, in a way that made me think the question was silly.

"All plants do," Philip whispered.

"This flower comes, though, when nobody seems to be looking, and it is much less curious than the leaves. It isn't even pretty." 
FLOWERS THAT HAVE ESCAPED 251

In this same place by the trees there were many Bouncing Bettys and a little way beyond, Tommy called, "Here's Tansy."

"Tansy, what a funny name," Kate Hood said, and Philip began singing:

"Tansy in a gown of green, Wears a crown that's golden; Tansy is my heart's gay queen, Tho' her vows she's broken."

"You used to sing that white crows were your sweethearts, and tell us the things they said to you," Tommy reminded him.

"I've changed," Philip said; it's nearly autumn now, and I only love white crows in the spring."

"Tansy's a good plant," Tommy said later. "It can cure people from sicknesses; but I think it's more a plain home body than a gay queen."

"It's gay because it has all these hundreds of little round flower heads, as hard as gold, and because its leaves are cut into fine little pieces that make them look dressed up and pretty. It doesn't look half as sober as that Rubber-plant."

Kate Hood said: "I know something about Tansy, although I've never seen it before. It makes people beautiful if they wash their faces with it after it has been soaked for nine days in buttermilk." 


\section{FLOWERS THAT HAVE ESCAPED}

This made both Philip and Tommy laugh, but Kate was quite serious, and told us Miss Amelia's maid had tried it before she came from Ireland to this country, and that she was a very pretty girl.

"It might take my freckles away," Tommy said.

We all laughed then, for there's hardly a place on his face that hasn't a freckle.

"I'm thinking," Tommy said, when we had stopped laughing, "that perhaps long ago there's been a house here. Tansy likes to live near people, and Bouncing Betty and these Blackberry vines are ' escapes.'

A little way from the trees then we saw stones that both Tommy and Philip thought had once been the foundation of a house, and when we saw three currant bushes farther along, I asked if we had come to where the haunted house had been.

"Indeed," Philip said, " that house was a long way the other side of Warley Towers. It's too far away even for us to walk, which is a pity, although we might not find any 'escapes ' there. It's likely they have the sense to move away from haunted places."

"Perhaps the house burned down that once was here," Tommy said; "for if it had been haunted, or deserted, there would have been more of it left than just these stones. They wouldn't mean much though, if it weren't for the flowers about here being the kind that like to live near people." 
FLOWERS THAT HAVE ESCAPED 253

We all wondered then a good deal about how the house had looked that once stood in this spot, and about who had planted the garden and picked the currants. I said:

"Perhaps it was all very long ago, and the children grew up and went away like birds that leave their nests. Then the old people died and the house burned down, and all that was left in the garden was three currant bushes, and Bouncing Betty and Philip's Tansy Queen."

"There's something else left," Kate Hood called. "See that big Sunflower. It's just opening."

Tommy thought that perhaps it used to be in the middle of the garden, and that the currant bushes were along the north side.

We all thought he must be right, and as there was nothing more for us to wonder about we went on to the pond to catch bullfrogs. 


\section{CHAPTER XXXIX}

\section{SINCE AUTUMN HAS COME}

IT is no use making believe any longer that summer is still here. The flowers that really belonged to summer are gone. Now autumn has come, and its own flowers are blooming.

A few autumn flowers were here in summer, nodding their heads to the warm days and perhaps wanting to say: "You'll soon be gone. I'm wearing an autumn dress, you see, and my friends are on their way to take your flowers' places."

Then, perhaps, the summer flowers answered: "We've had a happy play spell and are ready to go now."

Anyway I noticed that they soon drooped their heads and let their seeds grow very fast. I noticed also that summer flowers had not nearly so many in their families as the autumn ones have, and some of them were a little shy about being seen. Now autumn flowers are not the least bit shy. They love to grow as high and fine as possible, and wave and bob their heads in the wind. They come up in the fields and swamps and sometimes in the woods, but we see them especially along the roadsides. On both banks of the road now there are high beautiful flowers, white and purple and golden. Of course they are quite different from 


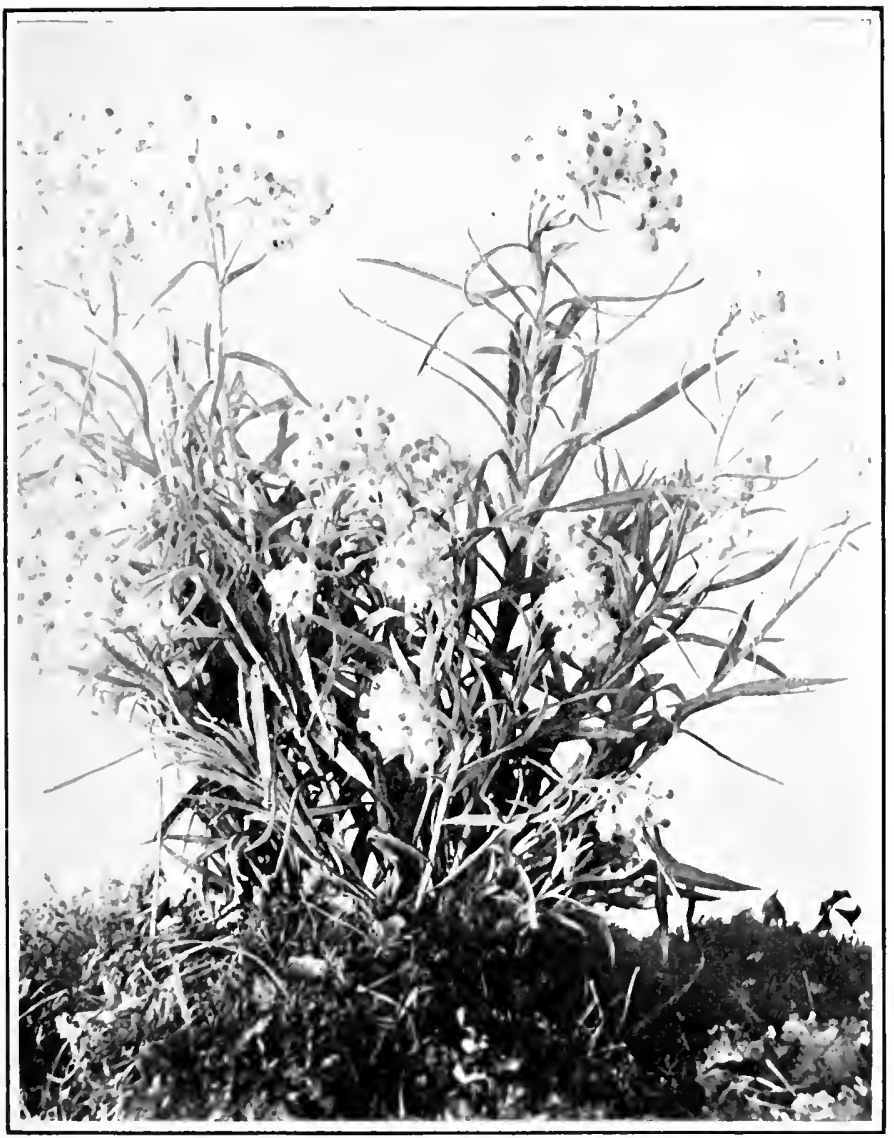

PLATE LXI,-EVERLASTING, OR SWEET BALSAM 


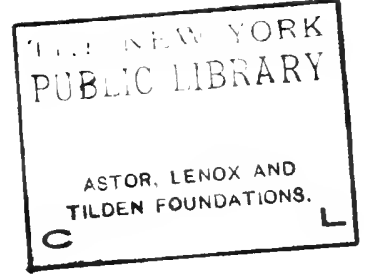




\section{SINCE AUTUMN HAS COME}

the ones that came in spring and early summer. They seem to have just been saved for the autumn, when the trees' leaves are changing from green to scarlet and yellow.

Often now there is a high wind blowing, and Tommy begins to talk about chestnuts. He doesn't love the autumn as much as the spring, for he says it is close to the time when there'll not be a flower in sight.

One flower that came when the Foxgloves and Wild Bergamot bloomed, and which is here still, is called Everlasting, or Sweet Balsam. It has ever so many little flower-heads, all in a group together, and growing at the tops of the stems. They are white with a tiny tint of yellow in their centers, and they feel more stiff and dry than any other flowers I have seen in the country. The leaves of Everlastings are the shape of blades of grass, and they are covered with a thick, whitish wool. I think their own color is a very pale green.

One day I picked a little bunch of Everlastings on the side hill where Philip goes to gather Huckleberries. Sweet Fern also grows there, and I can tell when I am near by its spicy fragrance. I put the Everlastings in my room, and every morning when I awoke, I looked to see if they had faded. At first I hoped that they would keep fresh a long time, and then I began to wonder if they were ever going to fade at all. It didn't seem to matter to them whether their stems were in, or out of water. 
Each day they grew a little stiffer and then suddenly I felt sure they would never fade, and that this was why they were called Everlastings.

I can't tell just why, but I didn't love these flowers nearly so much as if they had drooped their heads and died after a day or two. Tommy doesn't like them much either. They don't seem to him like real flowers, because they have this funny way of living so long. It would indeed be strange if Violets, or Roses lived on like the Everlastings and had their stiff, straw-like feeling.

An old lady who keeps a bunch of Everlastings in her parlor all winter told Philip a story about them. She said that once an evil fairy took a spite against them, and cast a spell, forbidding that they should ever fade. Of course when they saw that all the other flowers were dying, they wanted to curl up and die too; but no matter how hard they tried, it was quite useless. The most they could do was to make their little centers turn from yellow to brown. They felt very sad at having to stay in bloom so much longer than other flowers, and when the evil fairy passed by and called them Liveforevers they knew it was her work, but they also knew that it would do no good to complain. So from that day until this they have bloomed a great deal, and whispered to nobody that they were ashamed.

Philip feels quite sure that Everlastings do die after all, because they leave the fields, and the side 


\section{SINCE AUTUMN HAS COME 257}

of the little hill long before Jack Frost comes, Perhaps it's only when they're picked and taken in the house that they live so long.

I don't suppose either Philip or Francis have seen any more fairies than I have; yet it does seem strange that they both should have heard stories about mischievous evil ones. I used to think all fairies were good and kind.

Anyway no fairy could have had a spite against Thistles. They bloom and fade just as they please, and come up in the pasture wherever their seeds have been sown by the wind. The bumblebees are their best friends.

I have found out lately that all Thistles are not alike. In our meadow there are two kinds, and it is quite easy to tell them apart. One has a thick stem and its flower-heads are very large. It is called Spear Thistle, or Common Burr Thistle. The other one's flower-heads are smaller, and the plant has many branches for them to grow on. This last one besides is tall, and people call it Roadside Thistle. This doesn't mean that it only grows along the roadsides, but that there it has one of its favorite places.

Uncle Hiram's back meadows are so full of Thistles that his cows must be quite miserable. They can't eat their very prickly stems any more than they like to eat Black-eyed Susans with the grass-like hairs on their stalks. It's a good thing for the Thistles, though, that they have these sharp 
prickers. Even boys hardly ever venture to pick Thistles, for they know the spines will stick in their fingers and make them bleed. I have never seen a bouquet of Thistles, but Francis has sent Grandmother a sketch of them which is the prettiest of all the flowers he has drawn.

On one side of the picture there is a flower bursting open to let its seeds fly. These are covered with long, silk-like hairs which help them to ride on the wind somewhat as sails carry a ship over the sea. Indeed Thistle-seeds can fly a long distance. Every year very many fly off from the Thistle heads, and find new ground to grow in, so it is no wonder Uncle Hiram thinks them as troublesome as Wild Carrot.

The real Thistle flowers are the hundreds of tiny purple tubes that are held together in the heads. I think, too, they must be full of sweets, for butterflies and bumblebees sip and sip from them the whole day long. One butterfly that loves them very much is called the "Painted Lady," perhaps because she has such beautiful spots on her wings.

Another tall flower that we see often now is called Iron-weed. Its flowers are also like little tubes and are held together in heads; and although they look a little like purple Asters there are no long and narrow flowers around their centers. The color of these flower-heads is reddish-purple, I think, and they grow in clusters on the branches. 


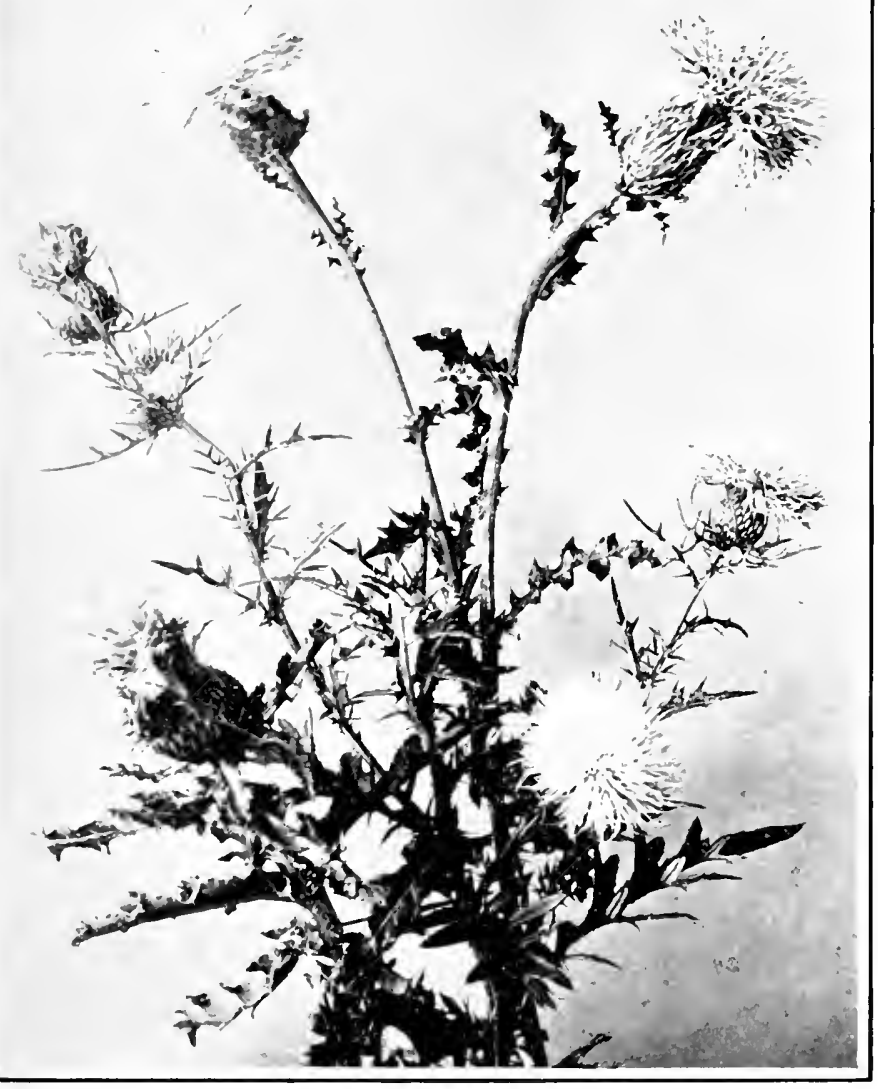

I'LATE LXII. ROADSHDE TIISTLES 


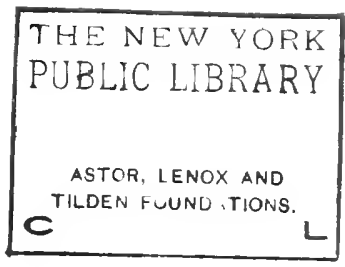




\section{SINCE AUTUMN HAS COME}

Iron-weed itself is most often taller than I, and its long, pointed leaves are like a saw about their edges.

I don't know why this plant was named Ironweed. There is nothing about it that is hard or strong, and it is much too pretty besides to be called a weed. It comes some time before the Asters, and even Uncle Hiram's meadow is like a garden in the places where it blooms. Tommy says it will begin to fade when the Asters come, and that they will burst open in such numbers, we won't even miss it. Of course I can't tell whether Tommy is right about this or not, because I have never been in the country in the autumn before; but now I think he has made a mistake and that I shall miss Iron-weed very much.

We walk along the roadsides now to gather flowers. The autumn ones make very fine bouquets, although Grandmother seldom puts them in the library. She says they are too bold, and need no coaxing, and that they look best in the hall. They are not vanishing, so we can pick just as many of them as we please.

Philip knows almost as much about flowers now as Tommy, but it seems to me that neither of them love the autumn ones so much as those they had to hunt and hunt for in spring. The young birds have all learned to fly now, and to sing like the old ones, and the only nests we find are quite empty. 
This morning I was glad when Tommy said he should start out in about a week and go to the bunk of a very curious flower. He said it looked much more like the spring and summer flowers than like the autumn ones, and that he was sure I would think it beautiful. He has kept its name a secret. 


\section{CHAPTER XL}

JOE PYE-WEED, THE STRANGE GIRL AND OTHERS

The day I learned to know Joe Pye-weed was the very one that Philip found out about the strange girl with straight hair. Tommy had gone away with his father that morning, and while Grandmother was taking her nap, Kate Hood came and asked me to go to Warley Towers to see what Philip was doing. Of course we took the short cut across the meadows.

Iron-weeds and Thistles and Everlastings were blooming there, and a few Black-eyed Susans that had forgotten to die with all their relatives. Then there was Joe Pye-weed. Kate Hood knew all about this plant, so we stopped a minute while she said:

"Joe Pye's more like a friend than a weed. Perhaps this is because it has such a funny name, and because it stands up so straight, and is so much taller than other flowers in the meadow. It seems besides as if all the plants must love it, and play it is a great strong friend who has come to take care of them. Look! all Joe Pye's little flowers are pinkish-purple. See in what large bunches they grow, and how very near they are to the top of the stems. Each of the tiny flowers is shaped like a trumpet, and two centerpieces stand 
up in their middle. It's they that give the whole bunch such a fluffy look. The people who call it Trumpet-weed do so on account of the little flowers."

Then she showed me that the easiest way of all to know Joe Pye was by its long leaves, which are narrow and pointed. They always grow around the stem in circles of six leaves each, although very near the top we saw one circle of only four leaves. But I could see all these things while Kate was talking, and I wanted most of all to know why the plant was called Joe Pye.

"That's because it is named after an Indian doctor who lived in New England," she said at last.

"Perhaps Francis would know something about him."

"If he did," Kate replied, " it would be that this old Indian was very wise about plants. $\mathrm{He}$ didn't care nearly so much for hunting and going on long chases with other Indians as he did about studying herbs, and finding out which ones could cure his people when they were sick. He made so many cures that even white people began to hear about him, for this was long ago, and the people in New England saw much more of Indians than they do now.

"Once a great many people became sick at the same time with typhus fever. It was like a plague in one little town. Then Joe Pye, who had grown 


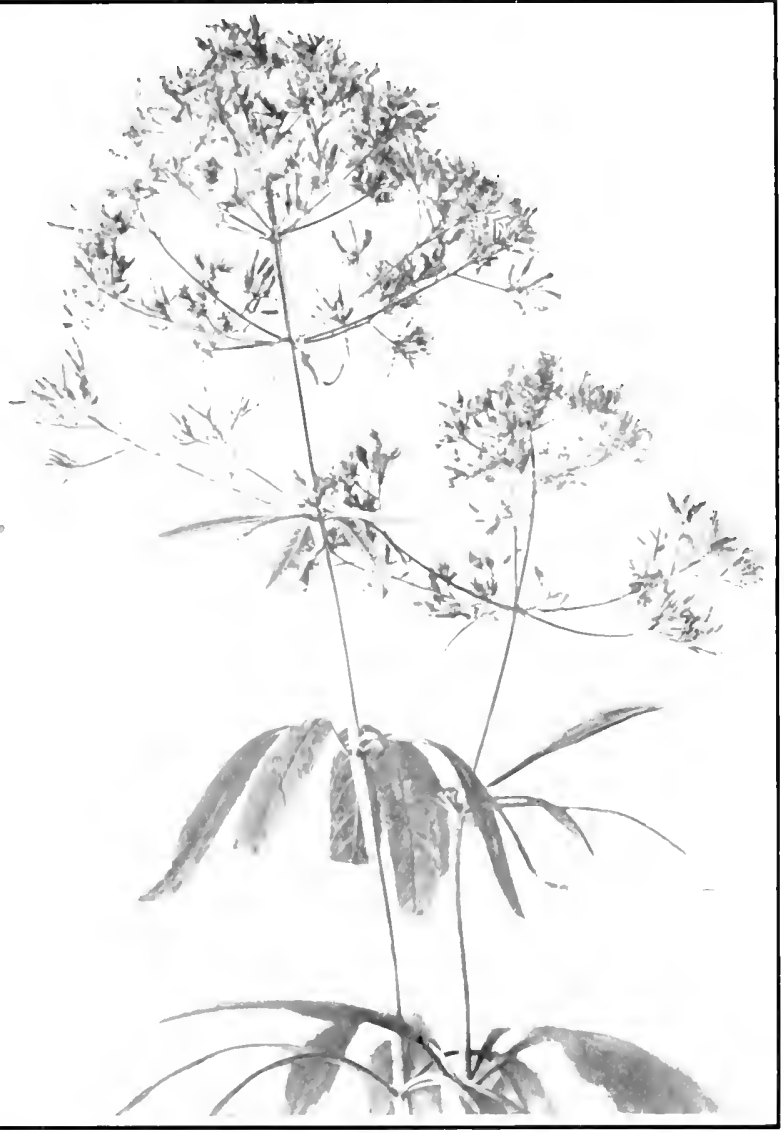

PLATE IXIH, JOHE PYIE-WEED 


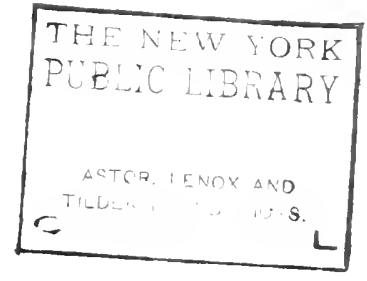


very old, went from house to house curing the people. He did it by using this plant in some way, and afterwards the people gave it his name."

I had been listening to Kate Hood's story every minute and neither of us heard Philip until he gave a great shout close to our ears. By his face and the way he waved his arms and skipped about, we knew that something must have happened.

"Shc's a real girl," he shouted, " and her name is Lucy. She lives in the little brown house covered with vines, and she has no brothers or sisters. She isn't the spirit of Secret Valley, nor of the Dogwood, nor of the meadows any more than we are."

I began to think Philip must be talking about the strange girl with straight hair.

"Did you really see her and touch her?" I asked.

"Yes," Philip answered, "she was up in the field beyond this where there's more Boneset and Milfoil than anything else. She was leaning against the stone wall, until I jumped over and scared her almost out of her wits. She started to run then, but I ran, too, and faster, so when I caught up to her she told me her name was Lucy. She doesn't know any children around here, for she only came to live in the brown house this spring, and she has no friends but the flowers and birds."

I thought I was the only little girl here who had bcen learning about the country since spring, and 
it seemed strange that some one else had been doing the very same thing.

"Did you ask her how much she had found out?"

"She said she knew we were all friends and had jolly times together, because she had seen us often when we were out looking for wild flowers. She didn't know why we always ran away so fast whenever we saw her, and then I told her it was because we thought her a spirit and not a real girl at all."

"She laughed a good deal, and said, 'Perhaps I'm both.'"

Philip said she was very pretty when she laughed.

"Where did you leave her?" Kate asked.

"Over there in the field," Philip answered. "I ran here to tell you and Tommy that I'd found her."

"Let's go back and see her now," I said. "Tommy's not home to-day."

We started then for the next field, and were soon there, but Lucy was no longer in sight.

"She's back in her brown house by this time," Philip said, and he looked disappointed. "There's no knowing now when we'll see her again."

I looked all around, but there was no girl in the field, nor even Joe Pye-weed. Here there was only grass and Boneset and Milfoil. It all looked white and misty, for the day was not quite clear. 


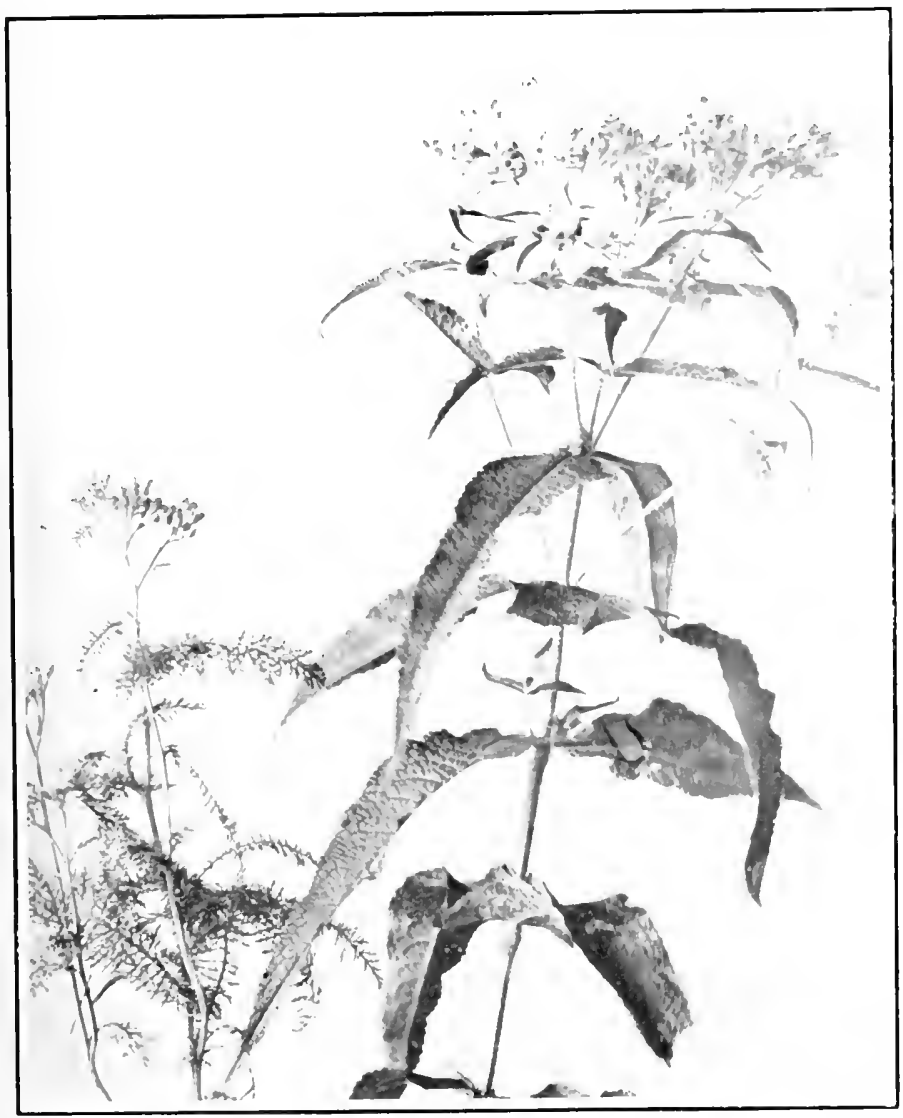

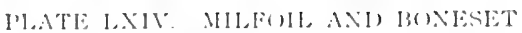




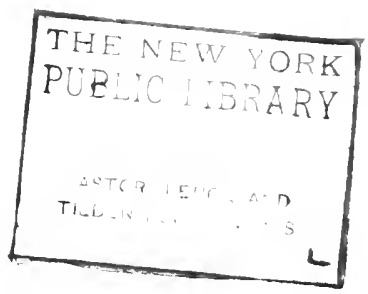


I have not written yet about Boneset and Milfoil, although we have been noticing them for a long time. They are both a little weedy looking, and their flowers are white. Some people think they look alike, but this could hardly be after they have had on what Grandmother calls their thinking-cap.

Boneset usually grows larger than Milfoil, and has bunches of tiny white flowers all in the shape of tubes. But it is by the leaves that any one can learn to know Boneset. They are long and narrow and taper down to a point. Then they grow opposite to each other on the stem, and close around it so tightly that it is hard for me to believe they are not just one leaf with the stem pushing through. These leaves, besides, look as though they were all little patches. They are not smooth and shiny like most other leaves, and when Boneset grows by the roadside where they get dusty I have thought them very ugly.

Although Tommy doesn't think that the Indian doctor, Joe Pye, knew much about Boneset, there were other Indians who found out it could cure the kind of colds and fevers that make the bones ache so hard they feel like breaking, and that this is why Boneset was chosen for its name. Grandmother says, though, that most old-fashioned people used to call it Ague-weed.

When Grandmother was a little girl and had a cold, she drank tea made from Boneset leaves. 
She says it was bitter and horrid to take and that she is glad people no longer give it to children. Tommy says Uncle Hiram takes it himself sometimes, and likes it better than lemonade.

Milfoil, or Common Yarrow, that lives in the meadow with Boneset, has also many little white flowers growing in a large bunch at the top of its stems. They are different from Boneset flowers because they are made more like a Daisy, and have both kinds of flowers in the heads; little square ones that look like petals around the edge, and other tiny ones the shape of tubes in the center. It seems very wonderful that each of these tiny things in the center is a real flower all by itself, and that each of the five little white squares around the center is also a true flower. Some time I am going to put one of these flower-heads under Grandmother's magnifying glass, and then perhaps I shall understand them better.

The leaves of Milfoil are very different from Boneset's. They grow one above the other on the stem and are just as much divided into little parts as the leaves of Fernleaf Foxglove. Milfoil looks more pretty and delicate than Boneset, although it is also very strong.

Tommy says it has lived in many countries. It grew in the fields and along the roads when Achilles lived, and found out there was something in it that would cure the wounds of his soldiers. It is written in history besides that he used it for 


\section{JOE PYE-WEED $26 \pi$}

them, and botanists as great as Professor Bonn have given it a name which they use themselves, in memory of Achilles.

On the way home I told Philip and Kate Hood that it was so long since I'd been to school I'd almost forgotten about Achilles. Philip hadn't, though, and he reminded us that he was a famous Greek warrior who lived long ago. 


\section{CHAPTER XLI}

THE STUDIO FAVORITE AND TURTLE-HEADS

When Tommy came home we told him that Philip had talked with the strange girl whose name was Lucy, and that she lived in the little brown house. Of course, he was afraid to ask any questions, fearing this might be another of Philip's jokes. But after awhile he saw that we were all quite serious. He remembered then that it was time to look for the curious flower he had told us about a few days ago, and said its bunk was only a little way from the brown house.

"Tommy," Grandmother said, "you and I will go to see Lucy first, and later you can all look for the flower."

They started together and walked along the narrow road that we take less often than the others. When they were near to the house, they saw Lucy on the veranda, rocking herself backward and forward in a great wicker chair. They saw her plainly, for there were no longer any Wistaria blossoms, and hardly any leaves on the vine that grew to the top of the roof.

Grandmother asked Lucy if her father was at home. She had heard that Lucy had no mother. and that her father's name was Paul Leonard.

"Father is in the studio," Lucy answered, and ran into the house. 
Grandmother and Tommy waited on the veranda then until they both came out together. Tommy thought that Mr. Leonard looked like a king, although I don't know why he should think so, as he has never seen one. He has long black hair, and instead of wearing a coat when it is cool, he throws a little cape around his shoulders. He is an artist, and has lived for many years in Paris. He said it was likely that Grandmother had known his mother long ago. He had come to live in the little brown house because he had wished for a quiet summer, and to paint a great deal, but it had been lonely for his little girl.

Then he asked Grandmother and Tommy to go into his studio, which Tommy says was different from any room he had seen before. It took up nearly the whole of the little brown house, and the ceiling was made of glass, through which they looked up to the sky. Hanging on the walls he saw three pictures of Lucy, and each one made him think of the way she looked when he saw her first in Secret Valley.

Grandmother told Mr. Leonard all about me. She said her little girl was never lonely, because there was Tommy, and Little Trudy, and Philip and Kate Hood for her to play with, and that we had had visits also from Francis and Sallie. They all laughed when Grandmother told them that she had called Lucy the spirit of Secret Valley.

What astonished Tommy more than anything 
else was to see a bunch of Wild Carrot on a table in the middle of the studio. When Mr. Leonard pointed to it, he said: "The Studio Favorite."

For a minute Tommy thought it must be some wonderful flower from far away. It looked so delicate and beautiful. He had never noticed before that its tiny, white flowers in round, flat bunches were as fine as lace, although he knew that many country people called the plant Queen Anne's Lace. He knew the reason it was also called Birdsnest was because the flower-heads, as soon as they were through blooming, closed together in the shape of nests. Before this day he had hardly given its leaves a thought, but he noticed now that they were cut in pieces as fine as ferns, and that they were a soft, pretty green.

Out in the meadows Tommy had always called Wild Carrot " the worst weed of all." It tormented farmers when it made up its mind to grow through their pastures, and made hard work to clear it away. He had never liked it.

Before they left the studio Tommy began to forget about its being such a trouble to the farmers, and to think that after all it was prettier than most flowers. He remembered that I had said it looked like fleecy, white clouds in the meadow.

On their way home Tommy told Grandmother that he had been surprised when Francis sent her the drawing of Thistles, but not nearly so much 


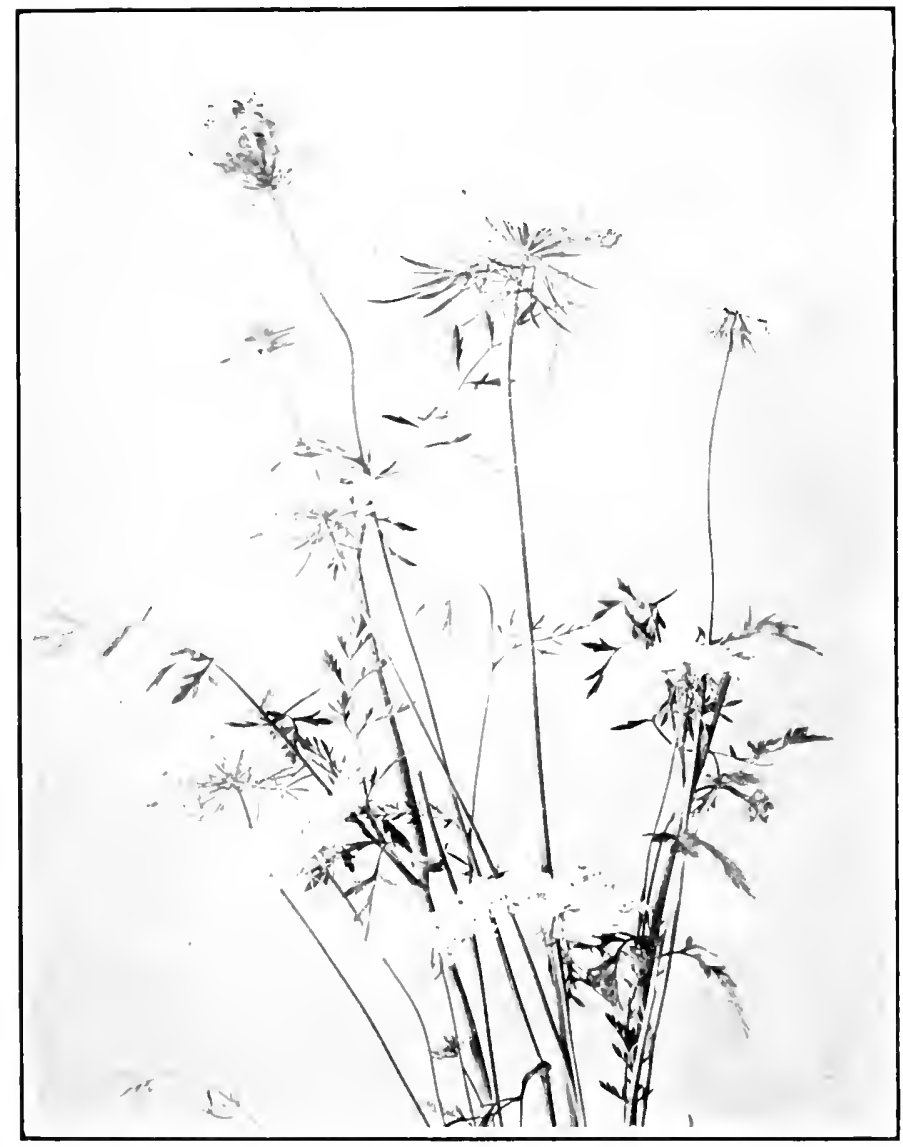

IAATE LXV. WIII CARROT 


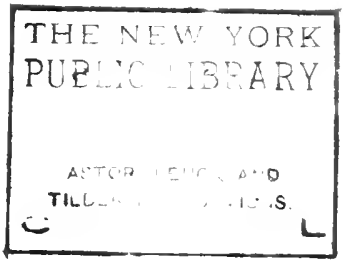


so as to hear Mr. Leonard call Wild Carrot "the Studio Favorite." Grandmother had no time to answer Tommy, for the rain began to fall quickly. By the time they reached the house, the wind was very high and masses of leaves were flying through the air. They were glad to get inside, for every minute the storm grew worse.

After luncheon we thought there was no chance of Lucy coming to see us then, so we might risk going out in the meadow together. It was still raining, and even if the sun should come out everything would be very wet. We watched by the window a long time to see if a little blue sky would peep through the dark clouds, and then when none came I said, "Let us go out, even if it is raining, and find the curious flower."

We put on our rubber coats and boots, and Tommy took an umbrella. Under it we had to walk very close together, and although the wind was blowing and making a great noise I could hear plainly all that Tommy said.

"I may as well tell you now," he began, "that the name of the curious flower is Turtle-head. It doesn't look a bit like other autumn flowers. You would guess that it bloomed in summer. It is a little too strong and tall for a spring flower; and it has neither strap-shaped flowers, nor tubes growing together in heads, the way of most autumin flowers.

"Turtle-heads are single flowers which grow at 
the ends of the stems. They are white with a pink tint, and so smooth that they make me think of wax. They look like snap turtles, which must be the reason that some one named them Turtleheads. Indeed it is very curious how much these flowers look like turtles. They have a tiny piece like a tongue sticking out from a part that looks like a mouth. But I can never make you understand just how funny they are, so hurry up! We're nearly there."

We had been walking along by the stream, and in one place the ground was so wet that when I pulled my foot up, the rubber boot stayed down in the mud. I wondered why any flower should choose this bunk if it knew how horrid it was on real rainy days. Joe Pye-weed was tossed about by the wind, and once a long spray of Goldenrod flapped under the umbrella and across my face.

"Here we are," Tommy cried, "and here is Turtle-head." I saw then that the flowers were like wax, and their turtle heads were ready to snap. He hadn't told me about the leaves, but they were long and narrow, and a little like saws around their edges.

"It comes up here every year," Tommy said. "I love it because it makes me remember the summer, and forget that Jack Frost is beginning to wake up after his long sleep. We won't pick it," he said, "but when the rain stops we will bring Lucy to see it, since we know now it is blooming." 


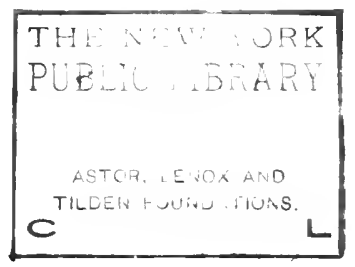




\section{THE STUDIO FAVORITE}

Just then I broke off one of the stems with four Turtle-heads at the top, because I also wished Grandmother to see why we had come out when it was raining so hard.

Before we went back Tommy pushed part of a tall bush aside, and as we looked through its branches we saw the little brown house not far away. 


\section{CHAPTER XLII}

BLUE FLOWERS THAT COME LATE

IT was not the next day after we had gone in the rain to find Turtle-head that Lucy came to see us, nor the next, nor even the next. It rained for three days almost steadily. At last, when it cleared, Grandmother said the Equinoctial storm was past.

While it was raining and the wind blowing, I thought that many of the wild flowers must have been drowned or blown over. But as soon as the sun came out, a dry, cool wind passed over the fields, and lifted up the heads of Joe Pye-weed, Goldenrod, Boneset and Milfoil, and all the other autumn flowers. This wind was quite different from the one that came with the dark clouds when it was raining. The flowers even looked brighter and prettier than before the dust on their leaves had been washed away.

Lucy came to see us on the day after it had cleared. She said she had not minded the long storm because her father had been painting a picture of her in a field of Wild Carrots.

"How could he do that in the rain?" I asked. "The Wild Carrots were all leaning over on their sides." 


\section{BLUE FLOWERS THAT COME LATE 275}

"Oh, father had painted them before on a clear day," she answered. "He put me in the picture afterward."

I thought this was very strange, and I made up my mind to write to Francis and tell him how Mr. Leonard painted his pictures.

Tommy was quite out of breath when he came in the library. Grandmother had sent for him, and he had run all the way over from his house. He sat down a few minutes, and then he asked Lucy if she had ever seen Turtle-head.

She said, "No," and that she only knew the names of a few large, autumn flowers.

"Lucy has no rubber boots on," Grandmother said, "and along the stream it must still be very wet. Perhaps there are other flowers besides Turtle-head that you might show her to-day."

"We had better go toward Old Adam," Tommy said, when we started.

Of course Lucy couldn't possibly love the old rock as much as we do, because she never saw it but once, and that was the day I spied her in the Dogwood bough. Then she was resting.

Tommy ran on ahead of us. We passed some Jewel-weed with its wonderful little flowers, hanging like gems, and Joe Pye-weed and Boneset and Milfoil were all looking their best. When Tommy was quite far ahead, I called out to him to come back. I saw a new bright, blue flower. He came so quickly that he stumbled and fell, and Lucy and 


\section{BLUE FLOWERS THAT COME LATE}

I had to pick him up and brush the mud off his clothes.

"It's Great Lobelia," he said, when he could only have seen blue and not the flower at all. "I didn't know it grew here. But then I know another one of its bunks that is not far from where we saw Turtle-head."

Of course I had to tell Lucy then that when Tommy said "bunks," he meant the places where certain flowers grow best each year. She nodded her head as though she understood. Lucy doesn't talk nearly so much as Tommy and I, or even Philip.

"Tell us about Great Lobelia," I said, for I wanted her to hear the wonderful way Tommy can talk about wild flowers.

"First tell me the name of its nearest relative," Tommy said, with his very wise look.

The bright blue flowers grew in long, narrow bunches at the top of the stems. I touched one with my finger. Two of its pieces stood up straight in the air, and the three others hung down, spreading out a little. But I noticed, sooner than anything else, that along the front of the flower there was a little slit, open place. The leaves were long and narrow, and grew one above the other on the stem. Perhaps they were a little thinner than most leaves, but there was nothing to make me think them especially pretty.

"It's late for this flower," Tommy said. "It 


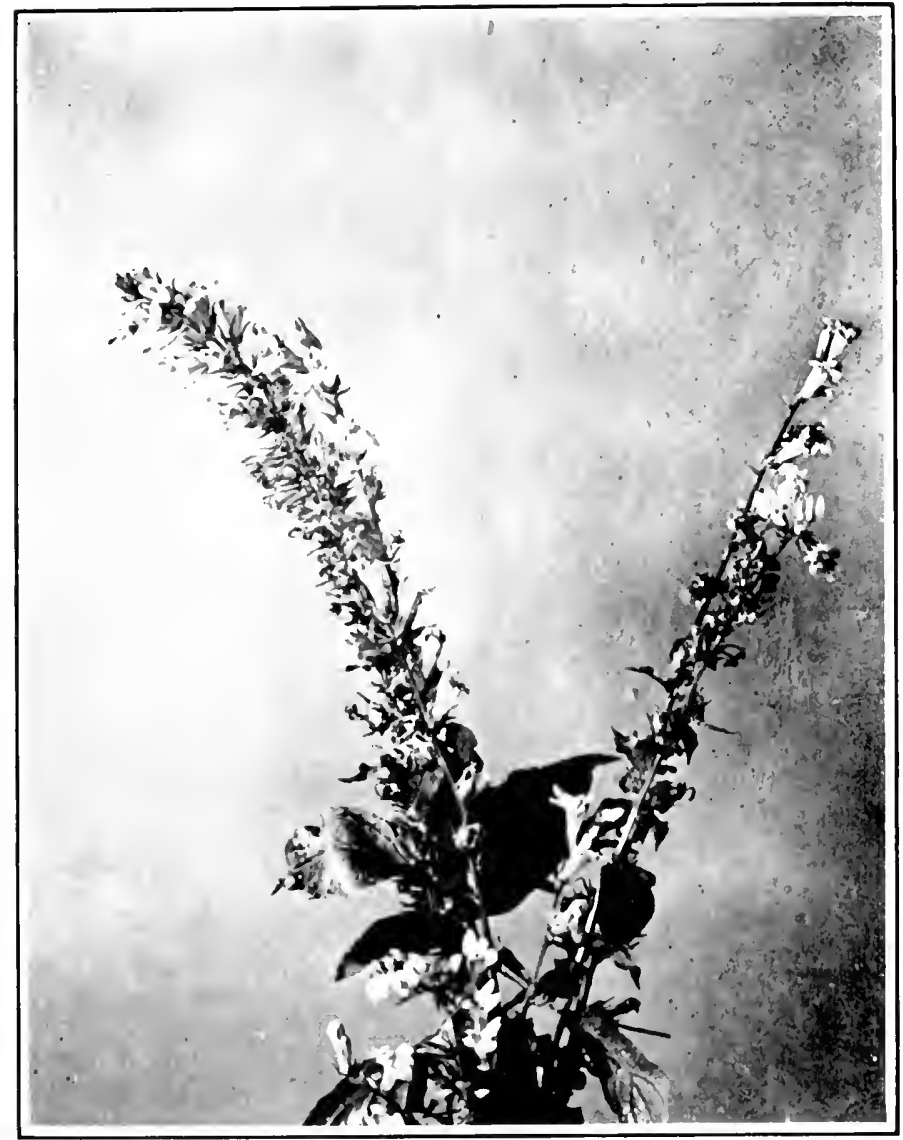

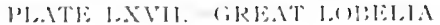




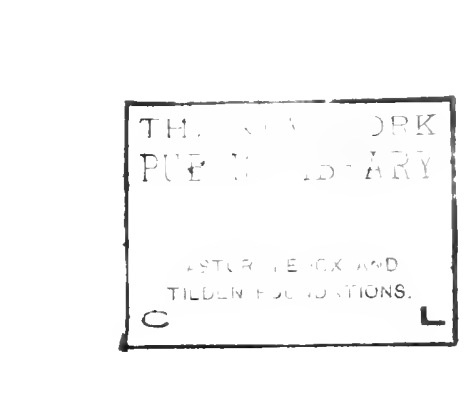




\section{BLUE FLOWERS THAT COME LATE 277}

opens just before the autumn." He was trying to help me think.

"It's related," I said, "to Cardinal Flower."

"Right," Tommy answered; "it's Cardinal Flower's brother, or sister; but how did you know?"

I was a little surprised myself that I had guessed its relative the first time. "It must have been," I said, " on account of the little slit and the way two of its pieces stood up, and three drooped down and flared out." I had noticed all these things about Cardinal Flower, and again, when Tommy had shown me a tiny blue flower growing like a weed in the meadow and had called it "Indian Tobacco," I knew it was also related to Cardinal Flower, and is the little plant with leaves tasting so much like tobacco that the Indians used to smoke them in their pipes. Just when I happened to think about some of these reasons that make Indian Tobacco related to Cardinal Flower, I saw the same things about Blue Lobelia. I was glad then that I guessed as I did, because I didn't wish Lucy to think I had lived in the country since before the trees budded, and had not learned anything about wild flowers.

"I didn't know plants were related," she said.

Tommy began telling her then some wonderful things about flowers, and that cach one belonged to a family with other members and relatives. He 
never stopped talking until we were nearly through the field and going into the woods. Then he stooped down to pick up a little flower named Large Purple Gerardia.

I had seen it before, and Sallie had written me about the Gerardias that grow near the sea, and make the sandy meadows so lively looking when Sundrops bloom beside them. The shape of these flowers makes me think of Foxgloves, but, of course, their color is pale purple instead of bright yellow. They are like fat, little bells ${ }^{+}$with five scallops around their edges. They always hold the big end up, however, and they drop off from their stems very easily. The Gerardia plants have many little branches, with leaves that are narrower than grass. When I take them in my hand they feel very stiff.

Lucy wondered how these flowers could have held on so tightly to the stems through all the rain. The one we had picked and put in Tommy's buttonhole had already fallen to the ground.

"Before we go into the wood, I want to ask you something," Tommy said to Lucy. "Have you ever seen Blue Gentian?"

"No," she answered.

"Neither have I," he said, and walked on whistling.

"I think Old Adam's asleep," I said, when we were in the wood. "Everything is so still."

"I'll wake up the old rock," Tommy cried, and 


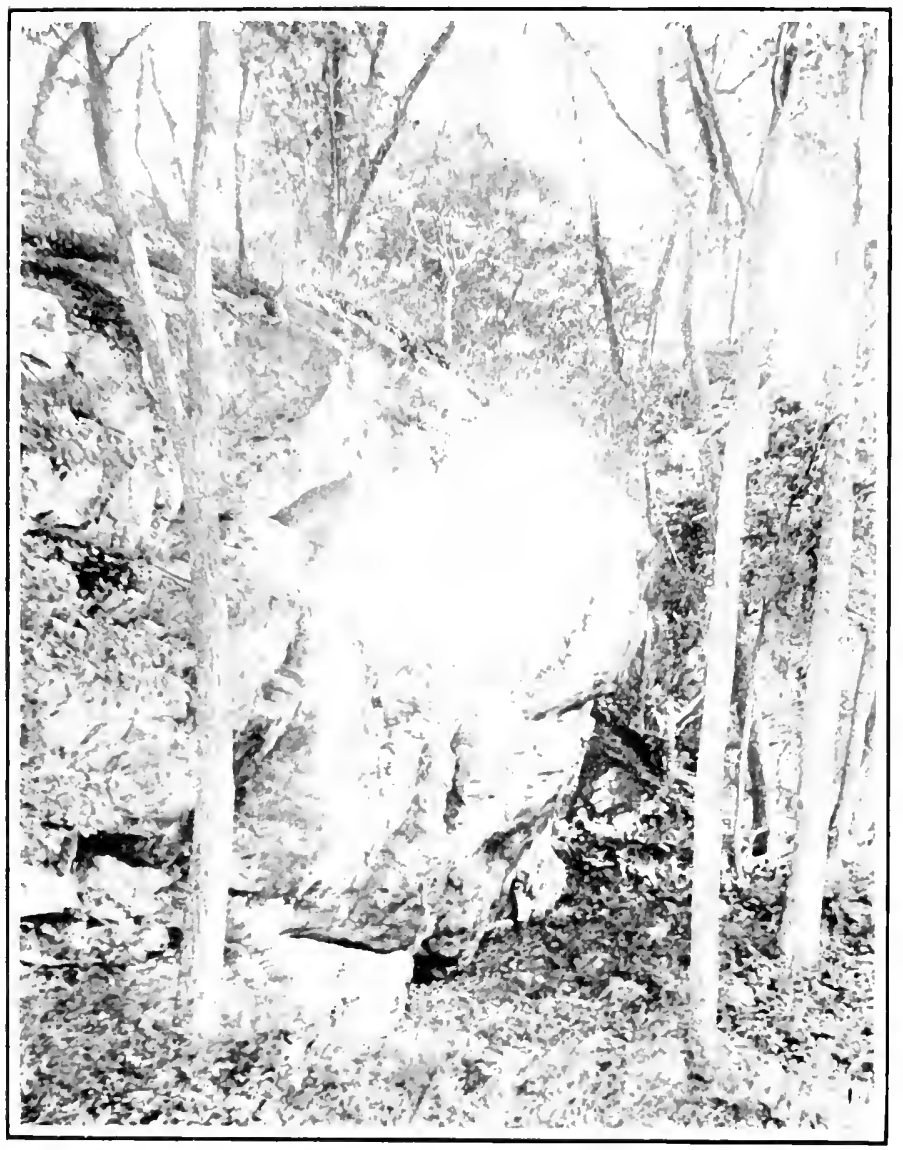

ILATE J.XVIII THE (H,I) RO(K 


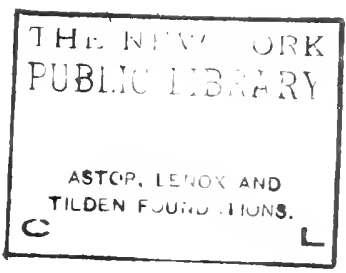




\section{BLUE FLOWERS THAT COME LATE 279}

ran to the highest point and shouted with all his might.

When Tommy does that he makes a great noise. I saw the leaves on the trees shake, and a few fell down, but Old Adam never stirred.

"It's because the flowers have left the rock that it looks so sad," I told Lucy, and then we tried to count all the different ones that had come and gone since the first Hepaticas. We could never get the number exactly right, though, because when Tommy counted he forgot some, and when I counted I forgot others.

Lucy said: "Perhaps Mother Nature has sent all the flowers she has for this season, and that is why the rock is left with only dead leaves falling around it."

We all thought this might be true. Then Tommy spoke again about Fringed Gentian.

"I know its ways and how it looks," he said, "even if I have never found it. There is a picture of it in nearly every one of my flower books. The flower would make most girls think of an oldfashioned garden pink, although it is not a bit like the Carnations Herr Wilhelm Fritz has in the glass-house. Blue Gentian has just four petals_"

"Lucy," I said, " he means the flower's leaves."

"And all around them there is a fine, long fringe," Tommy said, not minding that I had interrupted him. "It is a wonderful blue, as bright 


\section{BLUE FLOWERS THAT COME LATE}

as the sky when it has few clouds and looks its deepest shade. My books say that it grows in moist meadows; but I think it has vanished from those about here." Then we told Lucy about Wake-robins, and Arbutus, and Laurel, and how they had all moved away from this part of the country, and gone to places farther from men's dwellings. Blue Gentian must have gone also, because it was so beautiful people picked too much of it each year, and it had no chance to sow its seeds.

Just then Philip ran to the rock shouting, Hurrah! and saying that he and his mother were going to start in the morning for their visit to Francis in New England. 


\section{CHAPTER XLIII}

\section{INDIANS IN THE GOLDENROD}

Philip and his mother stayed for over a week in New England; and we have only heard, since they came back, about the Indians in the Goldenrod. At first Philip was not sorry he had gone visiting, because he liked to be with Francis. Things there, however, were almost the same as at home, and he missed Tommy and me. He looked over the fields, and down the road, and all he could see was Goldenrod, either standing still, or waving with the wind. "Just the way it looks now at Warley Towers," he thought.

Usually Philip doesn't take much notice of Goldenrod, and I am not sure that Tommy does either. Of course they can't help seeing it when it pushes Asters and Thistles and all the other autumn flowers out of the fields. They both know, besides, that the Goldenrod family has a great many members, more than they have ever been able to count.

Some Goldenrods stand up like bushes, and send out long sprays of small yellow flower-heads; others have flower-heads packed so closely together that they look like thick plumes, while again there are others that are thin and miserable looking. One kind of Goldenrod has a square stem, and the leaves of another kind have a sweet scent; one 


\section{INDIANS IN THE GOLDENROD}

of the family blooms first of all, and another waits to send out its flowers until its relatives are either dead, or dying. But although the Goldenrods have so many different ways of growing, there is a certain look about them all that lets children know their family name just as quickly as they recognize a purple violet.

Both Tommy and Philip agree that they haven't time this year to learn the special names of even the Goldenrods that grow in Grandmother's fields. It is only people like Professor Bonn who can remember them easily.

When Philip looked out the window and saw so many long sprays of Goldenrod he thought, there is one, anyway, that looks like those growing in the moist meadows at home, and he wished he was back with Tommy and me.

In the next house to where Francis lives there was a little girl and her brother, whose names were Jean and Dickey Vaughan. They were both younger than Philip. Indeed, Jean was only about as old as Little Trudy. Philip had already told them that he was afraid of nothing, not even bears; and he asked them how many birds they had caught by putting salt on their tails, and if they knew the names of all the wild flowers. Of course Philip was in one of his joking moods, only these children didn't know that, and as he talked, they wondered more and more.

The second day Philip was there, and when 


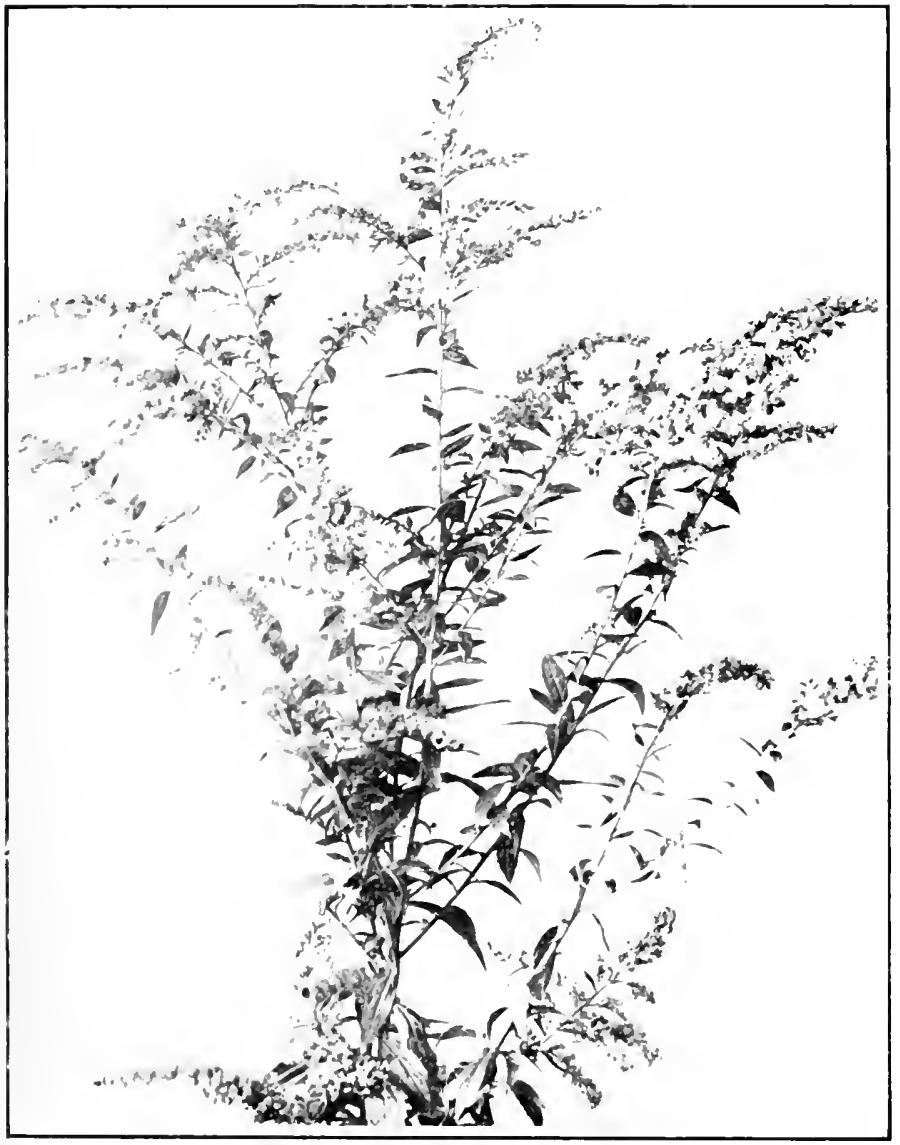

PIATE LAIX (IIIDENRUI) 


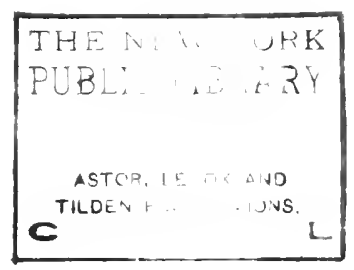




\section{INDIANS IN THE GOLDENROD 283}

Francis was having lessons, he told them that nothing in the world could scare him.

The little girl asked, "Not even Indians?"

Then Philip laughed, and said the jolliest people he knew were Indians, and that if there were any around there he would like to fight them.

"Indians go in the Goldenrod," Jean said; "but they don't fight, they only scare people."

Of course Philip paid no attention to that because he thought Jean was too young to know the real way Indians behaved themselves. $\mathrm{He}$ said that he was going out in the afternoon to see if there were any old birds' nests among the high bushes, and that he would go alone, because then he could see things better.

After that Dickey and Jean were very quiet, and once they went over to a corner of the room and whispered together. Philip was whittling a stick.

Dickey was a very good boy, only he was as mischievous about playing jokes as Philip, and his little sister always helped him. Now, Philip liked them both, and they liked Philip, because he was brave and knew so many funny things. He had told them all about Tommy and Lucy Leonard, and how Tommy had seen her first when he went to Secret Valley to look for white crows.

Dickey told Philip that he and Jean had had the best fun at their May party, when Jean had been dressed like a flower, and his suit had made him look like a beautiful butterfly. But when- 


\section{INDIANS IN THE GOLDENROD}

ever Philip said a word about Indians they ran right over to the corner and whispered.

As soon as Philip had his stick whittled he put on his little white cap and went out. Jean and Dickey saw from the window that he was going toward the meadow with the high Goldenrod, and they ran upstairs laughing and talking together.

Philip felt rather dull as he walked along. He began to think from the look of the flowers and trees that it would soon be school time again. He went a long way without finding a single empty bird's nest, although he passed by a number of very large Thistles, and Purple and White Asters, and Goldenrods were all about him. Joe Pyeweed was getting fuzzy looking, as though its seeds were ready to fly. It is too bad summer doesn't last forever, Philip thought, as he swung his stick in front of him until it knocked down a path among the tall weeds and grasses. The crickets were chirping so loudly that it seemed as if the whole meadow was singing their tune.

We'll have history, geography, spelling and a lot of other things at school this year, Philip was thinking, when, goodness, how his heart began to jump!

Just in front of him and in the Goldenrod there were two Indians. He felt for his stick, but he had dropped it somewhere, and he saw that the Indians had tomahawks. They came nearer and nearer. The tallest of the two was shading his 


\section{INDIANS IN THE GOLDENROD 285}

eyes with his hand so that he could look straight at Philip. The little one appeared very surprised. As soon as Philip's heart stayed still a minute, he thought he had never seen such small Indians before, nor ones with such jolly faces. The Indians he had seen always looked very grave, and he was sure they were much taller than Goldenrod.

Soon the big Indian took his hand from his face, and crouched down in the bushes. The little one did the same thing. Philip thought, "They're waiting to spring from their ambush; I'll wait also." So he burrowed like a woodchuck into a very thick clump of Goldenrod and sat quite still. $\mathrm{He}$ had hardly settled himself there when the Indians sprang from their hiding-place and shouted, "Fight, fight!"

They had long sprays of Goldenrod in their hands, and before Philip could get up on his feet, they were waving them in his face. That was a little too much to stand even from Indians. $\mathrm{He}$ grabbed another long piece of Goldenrod and cried, "Come on!"

The fight didn't last long, because they slashed the flowers off the rods, which soon broke. Then the little Indian lifted a tomahawk and hit Philip with it on the arm. The tomahawk bent and cracked open, and he saw it was made of paper.

That's quecr, Philip thought, and grabbed the little Indian around the waist. At the same time he looked the big one straight in the eye. 


\section{INDIANS IN THE GOLDENROD}

"If my name is Philip Todd," he said, " yours is Jean and yours is Dickey Vaughan."

"You were frightened at us," Jean said; " you didn't fight first, you hid in the Goldenrod."

"Of course I hid. I hadn't even a paper tomahawk to fight with, and real Indians don't use Goldenrod."

Dickey said: "You were scared at first, because you couldn't look me in the eye."

"I thought you were the littlest Indians I ever saw," Philip replied.

"You didn't know who we were at first, nor that I was a girl," Jean said.

"I found that out soon enough," Philip answered. "I knew you were going to try and frighten me when you ran off in the corner whispering before I came out."

"We put on our Indian suits and followed you," Jean told him, "and we were dreadfully afraid you would look behind before we came to the tall Goldenrod."

Philip said that if he were a girl he would dress like an Indian all the time; but Dickey said he hoped Jean wouldn't do that because she broke too many tomahawks.

Then they each put a long piece of Goldenrod in their belts, and took another in their hands, and marched home in single file. Dickey went first, then Jean, and Philip was last of all. 


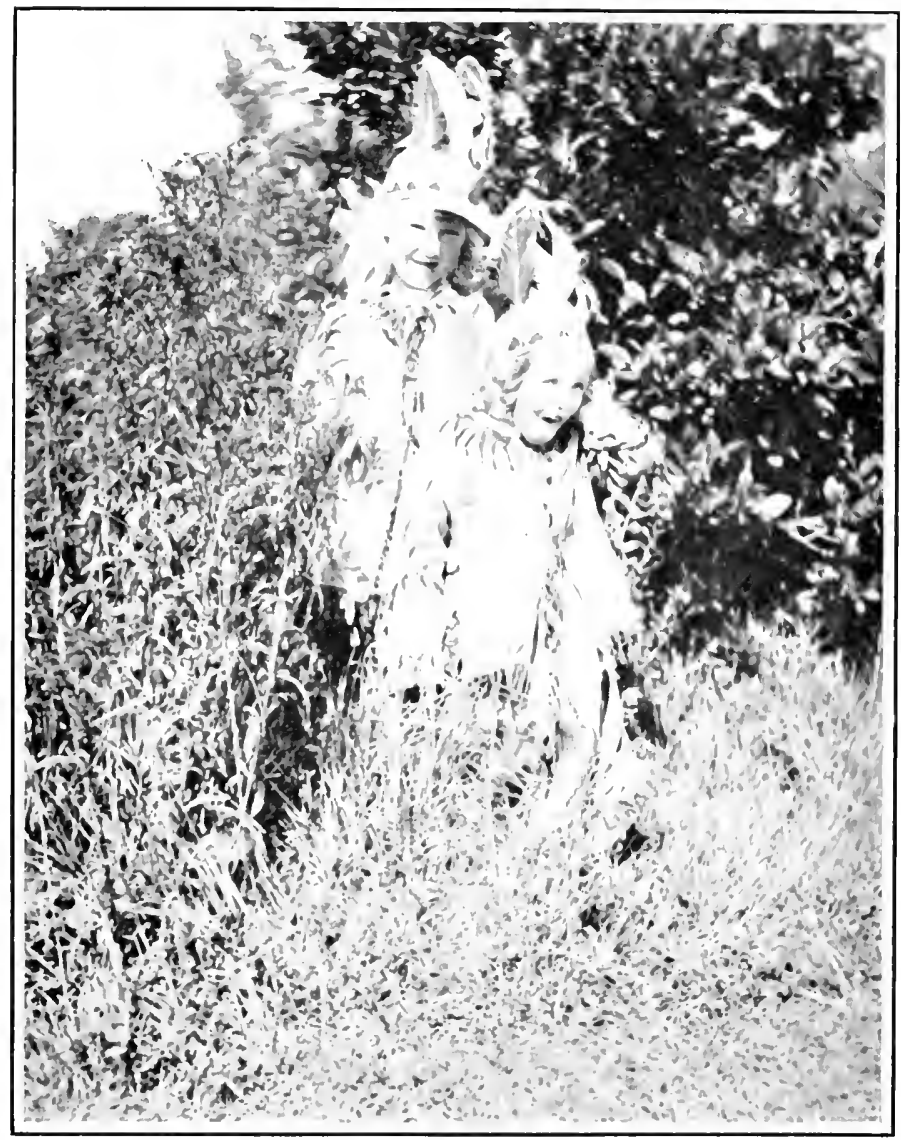




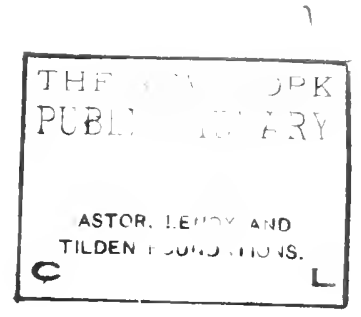




\section{CHAPTER XLIV}

CONCERNING ASTERS

When Philip came home from New England he noticed that Tommy had stopped talking about flowers being related. This was because the Asters had come. He said that any one could see they all belonged to one great family and that he knew it had about two hundred and fifty members. "Even if they were boys and girls," he said, "I think it would take a long time to learn all their names and what each one looks like. Perhaps we shall never see them all, for some live only on high mountain-peaks, while others can only be found in the Far West, or in the North, and some only grow by the seashore. These are the ones that Sallic will see."

The asters came into the meadows and by the roadsides very quickly. It seemed to me there were only a few of them one day, and then while I slept, or forgot about looking at them, they opened thousands and thousands of either purple or white flowers.

Tommy didn't talk about bunks either when the Asters came. We never hunted for them-they were everywhere. 
The Asters look something like Daisies, because their flower-heads are filled in the centers with tiny flowers in the shape of tubes, and around their edges are long narrow ones. I think, though, that the centers of Asters are not nearly so hard as the yellow eyes of Daisies; and that the flowers around their centers are more the shape of bits of string than little straps.

Most often Asters look like small bushes with branches in different directions. The white ones do not all grow in the same way. Neither are the purple ones all alike. Some white Asters are small, and others are large, and there are others besides that are a size in between the large and small ones. But there are not nearly so many white Asters as there are blue and purple ones.

There is one little white Aster that grows in a great many places and is just as fond of roadsides as it is of dry fields; it has very small flowerheads covering its branches so thickly that they sometimes bend them over like fairies' wands. I can hardly tell which one of its names I like best, it has so many.

Aster means a star, yet this one looks like ever so many stars. Professor Bonn usually calls it either White Heath Aster, or White Rosemary. Tommy calls it Farewell Summer, because it comes so late that he thinks it is waving the summer away. Philip's name for it is Frostweed, which is not nearly so pretty I think as Michaelmas 


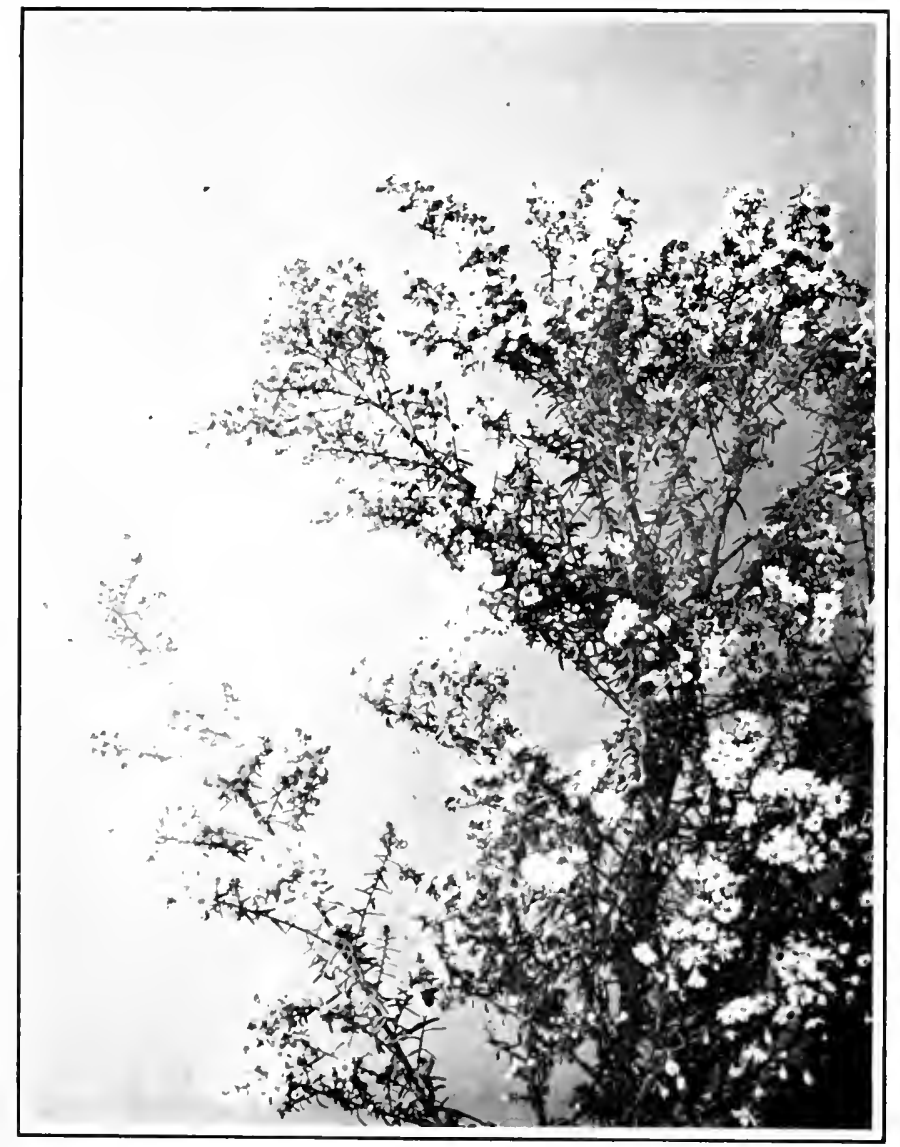

PLATE LXXI - MICIALLMAS WAIS 
$-$

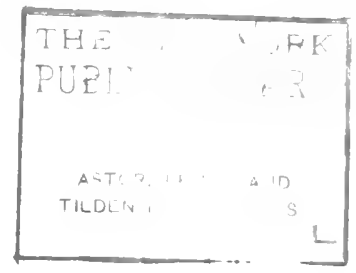


Daisy. This last name makes me think of winter and Jack Frost just as much as Frostweed, only Michaelmas is pleasant to think about, while plain frost is disagreeable.

Close beside Michaelmas Daisy we sometimes find Starry Aster, or White Wreath. Its flowerheads are smaller even than those of Michaelmas Daisy, and they grow all along the branches. These plants look very much like bushes. Sometimes they are so short I have to stoop down to them, but of ten they grow so tall that they make me stretch up to reach the branches. Any child might learn to know this one of the white Asters because its leaves are small and stiff, and look as if they were trying to be baby pine needles.

When Little Trudy found out this Aster was called White Wreath, she thought it was a wild flower that had come just for her to weave into wreaths. She picked a large bunch of it and sat for a long time making one for Tommy's head. But when it was finished the flowers had faded, so Little Trudy threw it away, and called it a naughty flower. Since then she has found out that some of the purple Asters also fade very quickly.

We only know the names of a few purple Asters. Tommy tries to tell them apart by looking very sharply at their lcaves, and counting the number of their ray flowers, as the long, narrow outside ones are called. Then he finds them in his books, and we learn their real names. Professor Bonn 
thinks it is just as foolish not to know a flower's especial name as it would be if we only knew that Philip belonged to the family of Todd.

The purple Aster that we see most often, which is in the fields with Goldenrods, white Asters, and bursting Thistles, is called either Purple Daisy, or Purple Aster. I like the first name best, because it looks like a purple Daisy. The flowers grow alone at the ends of little branches; and I have found out by counting that they have as many as thirty ray flowers. The leaves are thick and stiff and clutch about the rough stalk very closely.

Grandmother often gathers Purple Daisies for bouquets. When she picks them late in the day they close up and go to sleep, although in the morning they are wide awake again.

Another Aster that is a deeper purple than the Purple Daisy and which has as many as fifty ray flowers, is called New England Aster, or Starwort. Professor Bonn says it is found in many places, even in Canada, so it is not easy to know why it is called New England Aster. Underneath the yellow flowers of the center there is a little green cup which holds them, and this part of the flower is quite sticky. The flower-heads are about the same size as the Purple Daisies. The leaves are the shape of lances and they clasp about the stems very tightly.

It was August when this Aster first began to peep out. Now it is October and it is still here. 


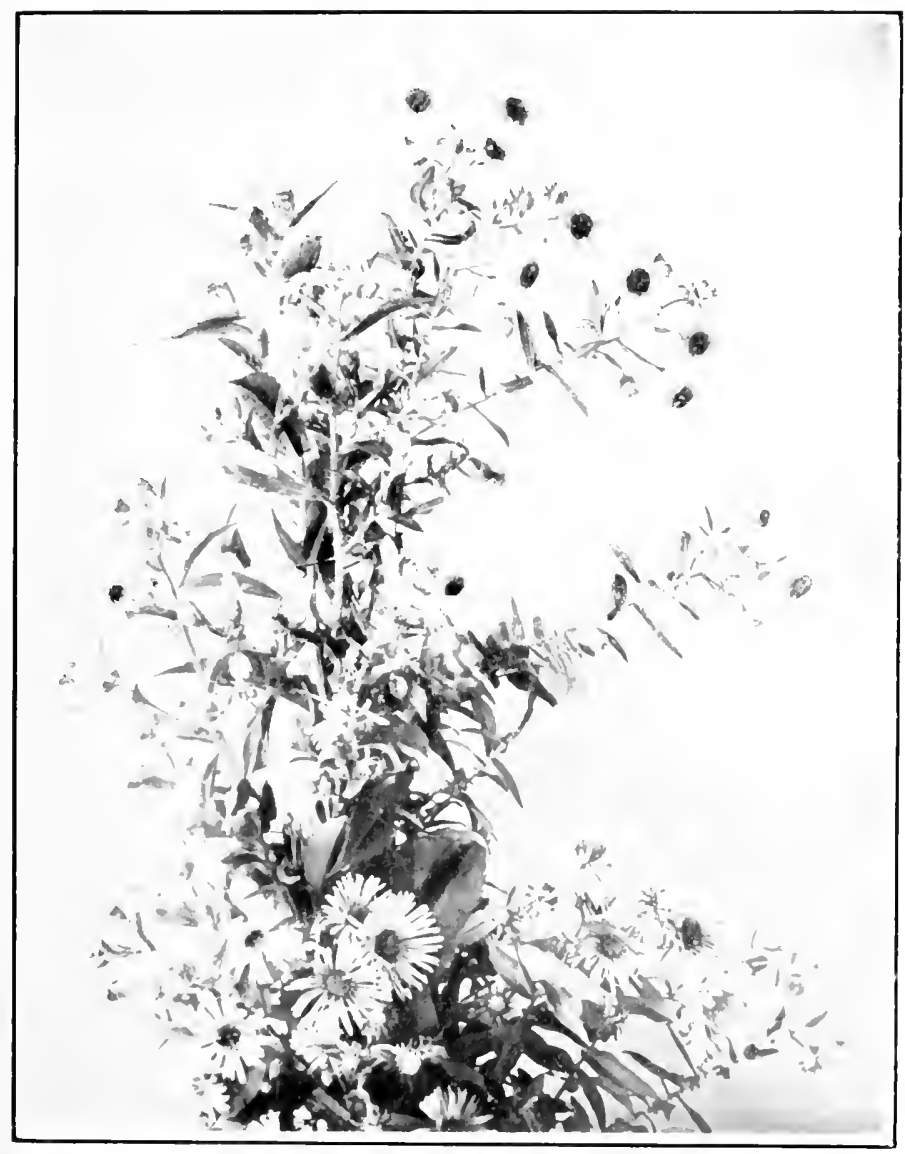

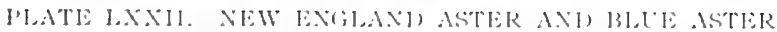




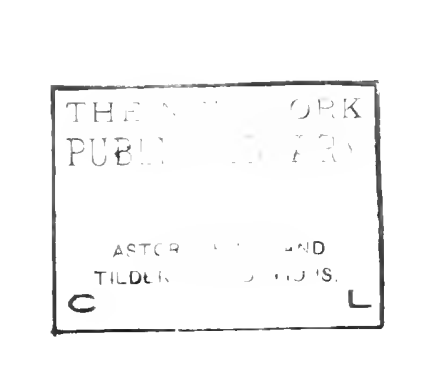


Even Goldenrod is beginning to turn brown and dead-looking, for last night there was a frost which nipped off its look of gold.

The Blue Aster, or Smooth Aster, as a large skyblue one is called, is still here with Starwort in fields and along the roadsides, and it grows, too, by the side of Old Adam in the wood. I think it is very kind of the Blue Aster not to forget the old rock, for since the cool, autumn days have come the flowers have left it quite alone. Only green things and a few berries are there now.

Tommy and I have wondered if the rock feels shivery and cold when winter comes. Of course there will be no chestnut gathering or Christmas for Old Adam: winter can only make it feel cold.

By the road outside the wood where Old Adam sits there are many Golden Asters. Their stems are covered with long, silky hairs, and although they are yellow as sunflowers they look very much like all the other Asters. In their flower-heads there are the same two kinds of flowers; long, narrow ones around the edges, and others crowded together in the centers that are the shape of tubes. These center parts of the Asters I have heard Tommy call their disks.

One day when I was looking at the Golden Asters, I heard the long grass rustling beside me, and soon Peter came and slipped his head under my hand. Nobody had petted him very much lately. I talked to lim for a long time, but al- 


\section{CONCERNING ASTERS}

though he walked more than half the way home with me, he turned and waved his tail "Good-by" before we crossed the road leading to Uncle Hiram's. 


\section{CHAPTER XLV}

\section{REAL AUTUMN}

Although autumn is here, and most flowers are taller than Little Trudy's head, she has not given up running away and finding them for herself. To-day she was lost again. Tommy went out after her, and a long way off he saw a bunch of flowers that seemed to be walking by itself. This was such a queer thing for them to do that he thought Little Trudy must surely be behind them. When he and the walking flowers were closer together, he saw that this was true and that Little Trudy was holding as many Wild Sunflowers in each arm as she possibly could. She was walking toward home and seemed very cross because Tommy had come to fetch her back.

These Wild Sunflowers grow all along the sides of the lane that leads from Tommy's house to Grandmother's garden. They look like the Sunflowers in Uncle Hiram's garden standing up by the fence, only they are smaller.

Tommy was astonished that Little Trudy had been able to pick so many, for the plants grew much taller than her head. She said: "Stems snap," and showed Tommy how she had given them a quick, sharp break. When they were back 
in the house Tommy helped her to put them in water in an umbrella-stand. There was no other vase large enough to hold them.

He gave her a little scolding then for picking so many, not, however, because Sunflowers are vanishing, but because the birds eat their seeds when they are ripe. He told her that it was getting harder every day for the birds to find food, and that Sunflower seeds were one of their last feasts before they went south.

"Little Trudy throw out crumbs," she said, and Tommy knew it was no use trying to make her feel sorry that she had picked the flowers.

Now she gets pieces of bread every day, and throws them out by the well; but only sparrows come to eat them, and these little birds are not favorites with Tommy's father. In the spring they build their nests above the windows or in the shutters of his house, and long before he wishes to awake in the morning they begin their noisy chattering. Yesterday one robin came for the crumbs. He looked very big and bold among the sparrows. They were just beginning to tease the robin and try to drive him away, when a chicken ran in among them. This made Little Trudy angry.

"Crumbs only for birds," she cried, and shooed the chicken away. The robin flew off also, and neither he nor the chicken have been back since.

Close to where the Sunflowers grow Pokeweed 


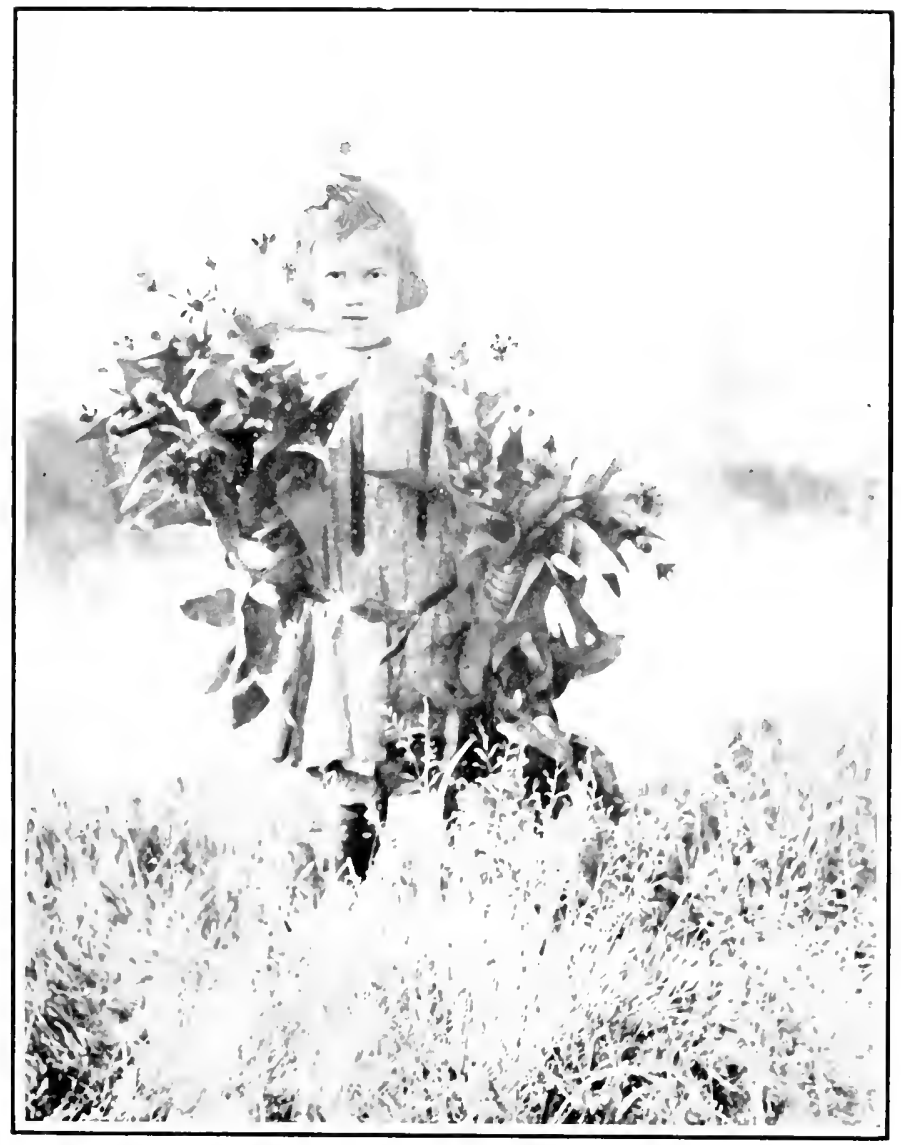

PI.ATE IXXII - IITTIE TRLDY WITH WHLD SLNFLOWERS 


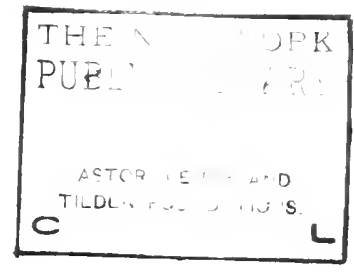


berries are hanging in long black bunches. At first Little Trudy was going to pick these berries instead of the Wild Sunflowers. She thought they were cuddling themselves together and that they were pretty and shiny. At the same time she saw the bushes' tiny white flowers.

"Very funny," Little Trudy said, for when there is no one near by, she talks to herself, "that wee flowers make big, black berries."

Then she pulled off a bunch and squeezed them so tightly that her hand and frock looked as if she had spilt an ink bottle. Trudy scowled and left them then for the Wild Sunflowers. Of course she didn't know that long ago the country people used to make their own ink from the juice of Pokeweed berries, nor even that many people now call them Pigeon-berries.

Pokeweed is a great, strong shrub. It stands up by the fence along the lane, and it is also by the stone wall between the meadows. Its leaves are large, and pointed, and smooth. The smallest things of all about Pokeweed are the flowers. They are white with a pinkish tint, and after they have faded their red stems hold the berries closely together in the bunches.

I brought a spray of Pokeweed home this morning, but before I got as far as Grandmother's garden the leaves and berries and flowers were drooping.

"That's Pokeweed," Grandmother said. "It's 
a true American, and it seems to me some one has called it an Indian sachem."

"That was Mr. Burroughs," Tommy called, for he had just come into the garden. "He said it looked over the fences like a painted Indian sachem."

I thought it didn't look a bit like an Indian. Then Grandmother said, "that was one of the poetical thoughts of a great man, but that it didn't mean Pokeweed had either the face or the figure of a sachem."

Just then Tommy laughed, and said I must have looked so hard at Pokeweed that I forgot about Burdock. That is the name I dislike most of all in the country. I looked right down at my frock, and all around the bottom it was covered with Burdock's prickly burrs. I hadn't seen them before.

They grow near the ground, and as I walked along my head was lifted up over the Pokeweed branch.

Burdock burrs, Tickseeds and Spanish Needles are some of the mischievous seeds that stick to boys and girls and even to grown-up people in the real autumn. They stick to cows and dogs besides, and nearly cover Uncle Hiram, because he says he doesn't care enough about looks to pick them off. They take such a tight hold of people's clothes that they can't be brushed or shaken away; they have to be picked off one by one. If Violets, 


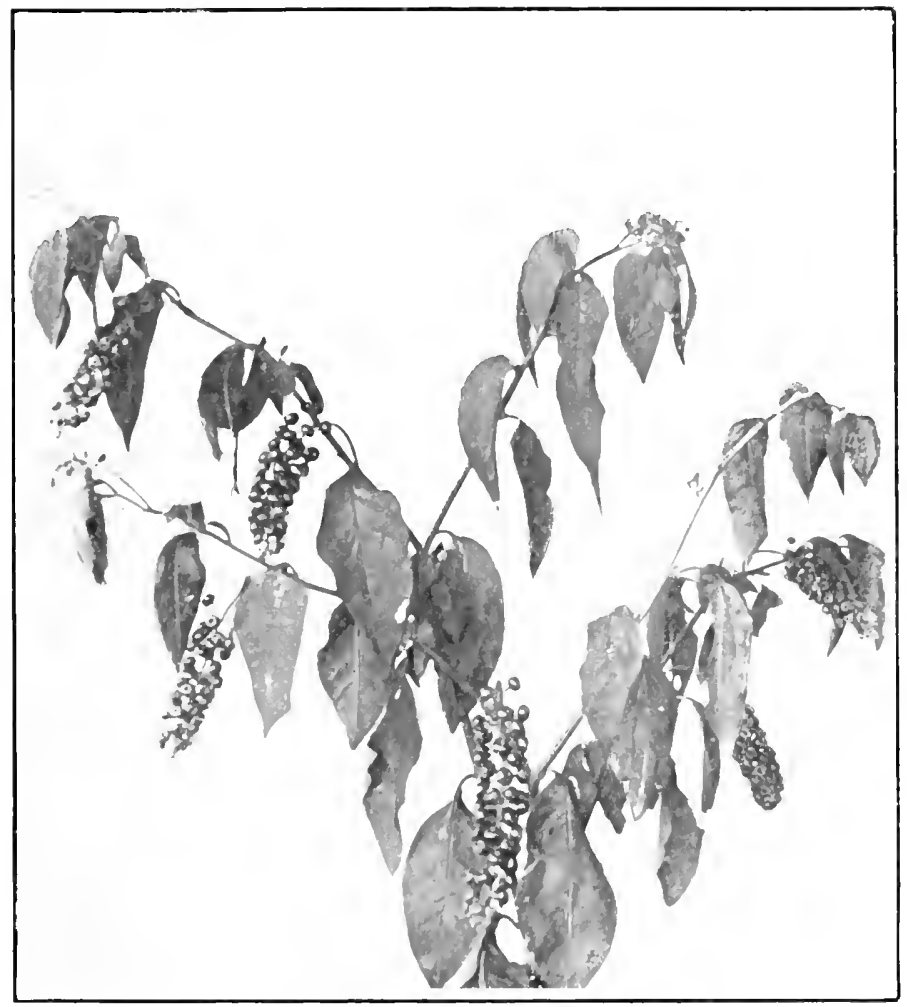

PIATE LXXIV.-POKEWEEI 


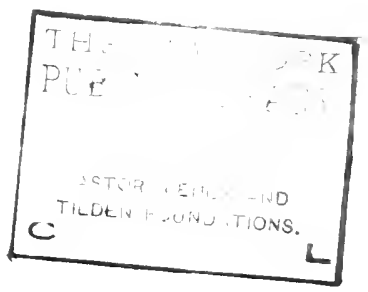


or Wild Roses clung to people it would be very different; but these mischievous seeds are all as ugly to look at as ugly can be.

Herr Wilhelm Fritz says: "Dey make der people do tings ven dey don't vant ter, and dat is not der fair play."

If we wished to sow seeds we would buy them in little packages and drop them in the rows of earth that Herr Wilhelm Fritz makes so neatly.

But the mischievous seeds take hold of us, and cling to us without our knowing it, and when we stop to pick them off, we are really sowing them, as they wish us to do. Most often we pick them off in the meadow, or along the road before we come home.

Unless it is the wind, I think no one has sown so many mischievous seeds this autumn as Peter. He has gone to live now with Uncle Hiram, and he only visits Tommy when he feels like it. Yesterday we passed him on the road, and so many little, roundish seed-pods were clinging to his long hair that he looked very funny. Burdock burrs were on his tail, and Spanish Needles were sticking out around the edges of his ears. His feet were wet and muddy as though he had been walking through a swamp and there were red marks in his eyes. Tommy hardly noticed him as we passed, and after the dog had barked and wagged his tail at me, he went on down the road by himself. Tommy began to whistle. It wasn't the kind 


\section{REAL AUTUMN}

of a whistle, though, that used to make Peter jump and run after him. His cap was pulled down over his face, and although Philip had told me that Uncle Hiram had a puppy in his barn which he was going to give Tommy, I kept the secret.

"Peter doesn't look pretty with all those prickly seeds sticking to him," I said.

"No," Tommy answered, "but he is growing more of a tramp every day. It's just like some of those autumn plants to have found out that Peter is a good one to help them sow their seeds. They are more clever than all the spring and,autumn flowers put together."

Just then I looked at Tommy's stockings. In some places they were quite green, owing to the mischievous seeds. Then he saw that my frock was also covered with them.

We had to sit down by the roadside and pick them off one by one.

"Let us mark this place," I said, " and come back next year to see the plants that have grown through them.

"Oh, the wind wili blow many of them away, and some of them will not take root," Tommy said. "Dame Nature has to make and sow hundreds of seeds sometimes before even a few plants come up that are strong and perfect."

But we did mark the spot. It was the side of a wall where a Great Mullen grows, and which farther along is covered with Poison Ivy. 


\section{CHAPTER XLVI}

\section{NUTTING TIME}

IT seems very strange to go to sleep one night in the country, knowing that all the trees' leaves are green, and to wake up in the morning and see that the tops of the maples have turned to scarlet, or yellow, and that the birches, ashes, poplars, and oaks are less green than they were the day before. No one sees how they change their colors, but I think it must be because they have grown ripe like berries, or else because Jack Frost has begun his traveling through the air.

The Scarlet Maples are the trees that had such beautiful red flowers in early spring. However, since the day this autumn when their tops first changed, they have been growing more red. Silver Maples turn their leaves a bright yellow, which is perhaps because they had yellowish blossoms in the spring instead of red ones.

Then when all the trees look very beautiful in ever so many shades of red, and yellow, and light brown, Jack Frost touches them again, and their colors grow dim, and their leaves begin to drop one by one to the ground. The bare twigs stand out by themselves, and the trees look much more dead than they did in the early spring when Grandmother and I came to live in the country. 
Nearly all the flowers have been bitten by Jack Frost. The Goldenrod looks very brown and gray, and there is surely not a fresh bud anywhere that would dare to unfold. Two nights ago Jack Frost knocked over all the Asters that were standing up straight in the meadow. They have a sick look now, and I think they will soon die.

The best thing that the frost has done so far has been to crack open the Chestnut and Hickory nut burrs. Kate Hood, Lucy, Philip, Tommy and I have all been nutting. We went too far for Little Trudy to walk, so we promised to bring her back more nuts than she could eat. On the way we wished that Francis and Sallie, and Jean and Dickey were with us, but Tommy said that most likely they were all gathering nuts near their own homes.

"Not such big ones as these," Philip said, as we ran under a Chestnut-tree, and began picking up the nuts.

"I have one," Lucy shouted; " and I," "and I," the rest of us shouted as we found them.

We turned each one over before dropping them into our baskets to see if there were any wormholes, or if squirrels had taken bites out of their sides. Indeed both gray and red squirrels like chestnuts very much, and they are up so early in the morning that it is hard to get ahead of them.

It is easy enough to see the chestnuts that have fallen out of their burrs lying on the ground. They 
look so brown and shiny. But Tommy seems to have an extra quick way of secing them. He had his basket nearly full, when Philip had only a few in his pocket, and Kate Hood and Lucy and I had just a handful besides the ones we had eaten.

From the chestnut-tree we went to a big, old hickory. On the ground under it there were more nuts than all of us together could gather. We could not eat them, for they were still green, and Tommy said we must take them home and spread them out to ripen on his woodshed roof, where the sun would make them dry and warm. Already he has nailed a board along the low side of this roof to keep nuts from sliding off.

It was so cold that my fingers stung, and we had to run around the tree to keep warm. When we were on the way home we went along the road that in summer was always shady. Now most of the leaves had fallen from the trees and lay in great heaps in the road. We pushed them before us with out feet, and both Philip and Tommy rolled over and over in them. These leaves, though, are clean and dry, and after they had shaken themselves, nobody would have known they had been rolling so close to the ground.

Along this road we passed two places where there were odd little yellow flowers. They looked like little bunches of strings holding tightly to the bare twigs. I thought as all the flowers were gone that perhaps Philip had cut these out of 
paper and stuck them on to the bushes for a joke. No one spoke about them, and then Tommy called out :

"You're a great lot of girls. We've passed Witch-hazel twice and you never noticed it."

"Witch-hazel," Kate Hood said, " comes in bottles."

"And it's made out of that shrub," Tommy replied.

The next time we saw these yellow flowers we climbed on the fence to look at them more closely. We couldn't understand why they should wait to bloom until all the other flowers were gone, and the trees were nearly bare. They were not exactly pretty flowers, although when many of them grew together they gave a soft, yellow look to the branches. But most often there were only a few of them together, and it was hard to see them because they were hidden by the large leaves which had turned yellow.

"Witch-hazel has its flowers when all the others are dead," Tommy said, "and in summer when flowers are everywhere it sows its seeds. These seeds," he went on to tell us, "are like little nuts. As soon as they are ripe the husks burst open, and the nuts shoot out as if they had come from a popgun. If you are standing near-by then, they are just as likely to shoot you in the eye as on the hand. Sometimes they shoot out farther than across the road. Of course witch-hazels want to plant their 


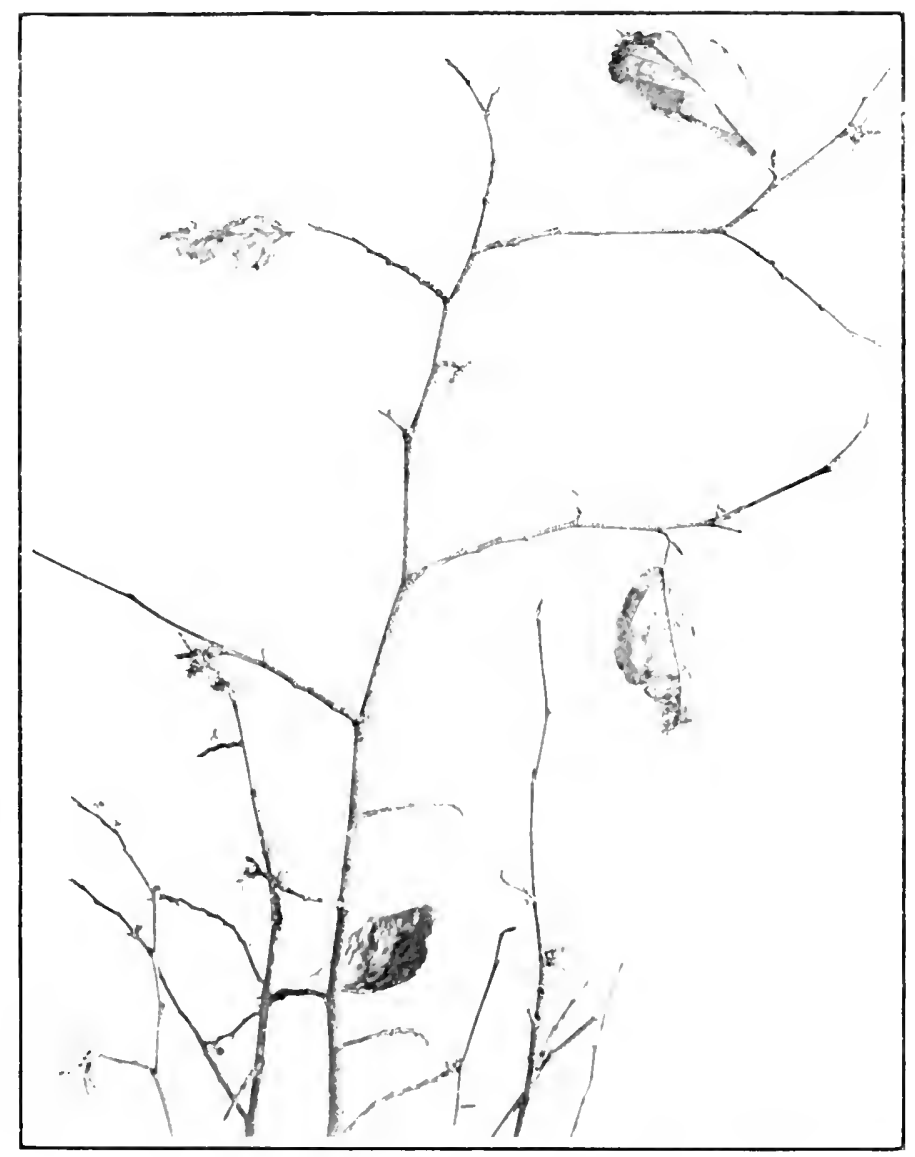

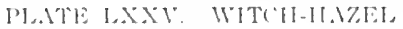




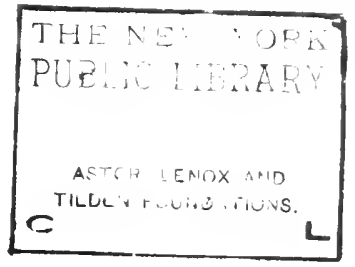


seeds as far away as possible, so that they need not all grow in one clump together. The seeds are not light enough to sail on the wind; and they have no prickers to catch into people's clothes, who will carry them away and sow them in different places. So the Witch-hazel thinks the best way to scatter its seeds is to shoot them out as far as ever it can."

"Perhaps that's why it is called Witch-hazel," Lucy said.

"No," Tommy told her, " it is called 'witch' on account of its twigs. They can show people where there is gold, or water, under the ground."

"Hurrah! hurrah!" Philip shouted. "WV'll find gold now."

He was going to break a straight twig from the shrub when Tommy stopped him.

"You must take a branch that is shaped like a pitch-fork," he said.

Fortunately there were a good many of this kind on the shrub, and soon we each had chosen one. We held the forked pieces tightly in our hands, and let the straight part point away from us.

"Now, we must walk around," Tommy said, " and when we pass over gold, or water, the long end of the twig will tremble and the whole piece will turn in oul hands."

We went down the road, and afterward into the meadow next to Miss Amelia's; but the twigs kept 
perfectly still, excepting when we moved them ourselves. It seemed to me that they were always going to keep still when suddenly Lucy's twig began to tremble, and the long, straight end turned in toward her, while the forked pieces that she held in her hands tried to turn outward. It looked as if the twig were trying to turn a somersault.

Lucy was frightened, and although she tried to bend the twig back, it had a way of turning and pointing by itself.

"There's water under here," Tommy. said.

"It's gold," Philip said.

Lucy felt sure it was water, and as hers was the only twig that had trembled, we thought she knew best.

"It's mostly when people want to dig wells that they like to see the Witch-hazel tremble," Tommy said.

"We don't want to do that," Kate Hood said. "Why should we wait here any longer? My hands are cold."

We went back on the road then. Farther along we saw the Virginia Creeper vine spreading over the wall. It looked very beautiful, for its leaves had turned a deep wine color, and its blue berries were covered with a white mist. Some children mistake its leaves for Poison Ivy, although they could never do this if they looked at them sharply. They are something the shape of maple leaves, while those of Poison Ivy have three oval 



\section{NUTTING TIME}

leaflets. Besides, the berries of Poison Ivy are white.

Then we passed a tall shrub with many bright red berries, and leaves that tapered at both ends. They had no long, sharp points around their edges, and some of them were already falling from the twigs.

"That's the Large-leaved Holly," Tommy said, "and it is vanishing, so we must not pick a single one of its pretty berries."

"It is not like the Holly we see at Christmas," Lucy said.

"That one has already vanished from here, and lives mostly in the South," Tommy told her. "This is just another one of the family, which sometimes grows until it is a large tree."

On the Dogwood-trees where the little flowers had been surrounded by their four white leaves in May, and had made the woods so beautiful, we now saw groups of bright, red berries. When I stopped to pick a spray of them for Grandmother the others called to me to hasten on because their hands were cold.

I felt cold also, and Philip said it would soon be time for mittens and fur caps. Even Tommy said we would search for no more flowers until spring came back again. 


\section{CHAPTER XLVII}

\section{THE DREAM}

IT was night, and I thought that Tommy had a wonderful dream; although in the morning I wasn't sure whether Tommy dreamed, or whether it was I who dreamed Tommy's dream for him. I wasn't sure whether it was near the Fourth of July, or near Christmas, or whether there were any real people in the dream.

It seemed that Tommy was asleep by the side of Old Adam, and that a number of beautiful flowers walked before him, in a procession as long as that of a President. Each flower nodded to him as it passed; but I couldn't remember ever having seen one of them before. The first one was a white flower as smooth as wax. It hung its head under large, green leaves, which were hard to see because they wrapped themselves around a beautiful book.

"So you are Wake-robin," Tommy said in the dream, "and you are carrying away the prize that none of us won by finding you in May or June? I'd like to see that book and to know just where you hid yourself."

The flower gave a little laugh and said: "Ten times ten you passed me by in the wood. I hid 
myself beneath my leaves. I have not quite vanished from near Old Adam," and again it laughed.

It was so funny to hear a flower laugh that Tommy almost awoke.

Just then a Honeysuckle crept along.

"Dear me," it seemed that Tommy cried, " you're that Trumpet Honeysuckle I could never find. I see that your long red flowers are in little bunches. They are just the shape of trumpets, and your thick leaves grow all around your stems as if they were made of one piece. Where do you come from?"

Then the Trumpet Honeysuckle laughed in a way that sounded like a squeal. "You stepped on me once and hurt me," it said. "I don't like to have my leaves crushed, and I hope you will be more careful next summer when you go through Uncle Hiram's woods."

"So you live up there?" Tommy said in the dream, and he was going to ask the exact spot when another flower walked along.

"My name is Evening-Primrose," it said.

"You're very beautiful," Tommy replied. "If I knew where you lived I would go to see you some day."

"I live by fences and along the roads," the flower told him. "I am very easy to find, but come at twilight. It is stupid of children to stare at me in the morning. I open my flowers at dusk when my gay moth friends visit me." 
"Goodness!" Tommy cried out in the dream, as he caught the fragrance of the Primrose's pale yellow flowers, and a red and yellow flower pushed it along. "What a wonderful creature you are. You must be called Milkweed. I can tell that by. the shape of your flowers."

This flower also laughed, and it was a sort of crow. "Indeed," it said, "my name is Butterflyweed. I am a Milkweed, to be sure, and the handsomest one of the family. Next year perhaps you will visit me. I live in a rocky place by Miss Amelia's woods. Lucy, in the brown house, knows me well."

The flower crowed again, and made Tommy feel very much ashamed that he had not found it without having to be told its bunk. A flight of butterflies passed along beside it, and Tommy wondered if they could be the kind his caterpillar would turn into after he had had it in a paper box long enough, and fed it a rose leaf a day.

"I'll give that ugly worm two lumps of sugar if it will make him come out as beautiful as you are," he said in a sleepy, half-awake whisper.

The butterflies didn't seem to hear, for they went by so quickly, only a little one near the end turned back and said: "Punch another hole in the box to give your caterpillar plenty of air, and don't throw. him away when he weaves a warm and snug little house for himself."

"Indeed, I know the look of a cocoon," Tommy 
thought as he dreamed, and the little butterfly went on after the others.

It seemed then as though Old Adam gave a great snore. It was so long and so loud that the flowers walking after the butterflies tripped by very quickly. The rock had really gone to sleep for the winter. It was cold, and not a single flower stayed beside it. The leaves also had left the trees, and only far away a mischievous little Dandelion lifted its yellow head.

"It's chilly; how that boy sleeps!" a very proud, red flower lisped as it passed.

"I know you," Tommy said, as fast as his sleepy lips could move. "I never found you growing wild; but I saw you at the Botanical Garden where you have a little bed of earth all by yourself. Your name is Oswego Tea, or Bee Balm. You make me think of the Wild Bergamot we found the day of the picnic on Old Adam, only your color is red and Wild Bergamot's is lavender. Do you grow wild near my home?"

"Indeed I do," the flower answered. "I grow close to some beautiful Chicory or Succory blossoms that have just had their heads nipped off by Jack Frost. Some little boys don't know all the bunks around here yet." This flower gave a long laugh, and again Tommy felt he had been very stupid not to have found it and Chicory.

Every minute he had to dream faster, because the flowers went by so quickly. But there were 
none of his old friends among them. Violets were not in that procession, nor Columbine, nor Wild Rose, nor a single one of all the summer and autumn flowers he had found.

"Perhaps Old Adam and I have gone to live in a different country," he thought; "and if these flowers don't stop laughing, I shall open my eyes to see." Tommy stretched and looked so very serious that a tall Sunflower marching along never said a word. Then he went sounder to sleep than ever.

Next a Pond Lily went by murmuring very gently: "So you never came down to see me this summer. I like little boys and I don't mind being picked. I'm wise enough to keep my roots in soft mud under the water where they can't be pulled up. I'm not vanishing like Columbine, or Butterfly's Banners. If you come to see me next summer, I'll unfold a fresh blossom for you every day." The Pond Lily sent out such a sweet perfume as it passed that Tommy dreamed he had it on his handkerchief, and moved as though he were 'feeling for it in his pocket.

"Dear me," he said again in the dream. "I thought I knew all the flowers about here, but you're a jolly lot for me to look for next summer and tell Philip Todd about."

Somehow Tommy thought that he saw Philip back at school making ciphers on a blackboard, and Sallie in another school writing a composition about 


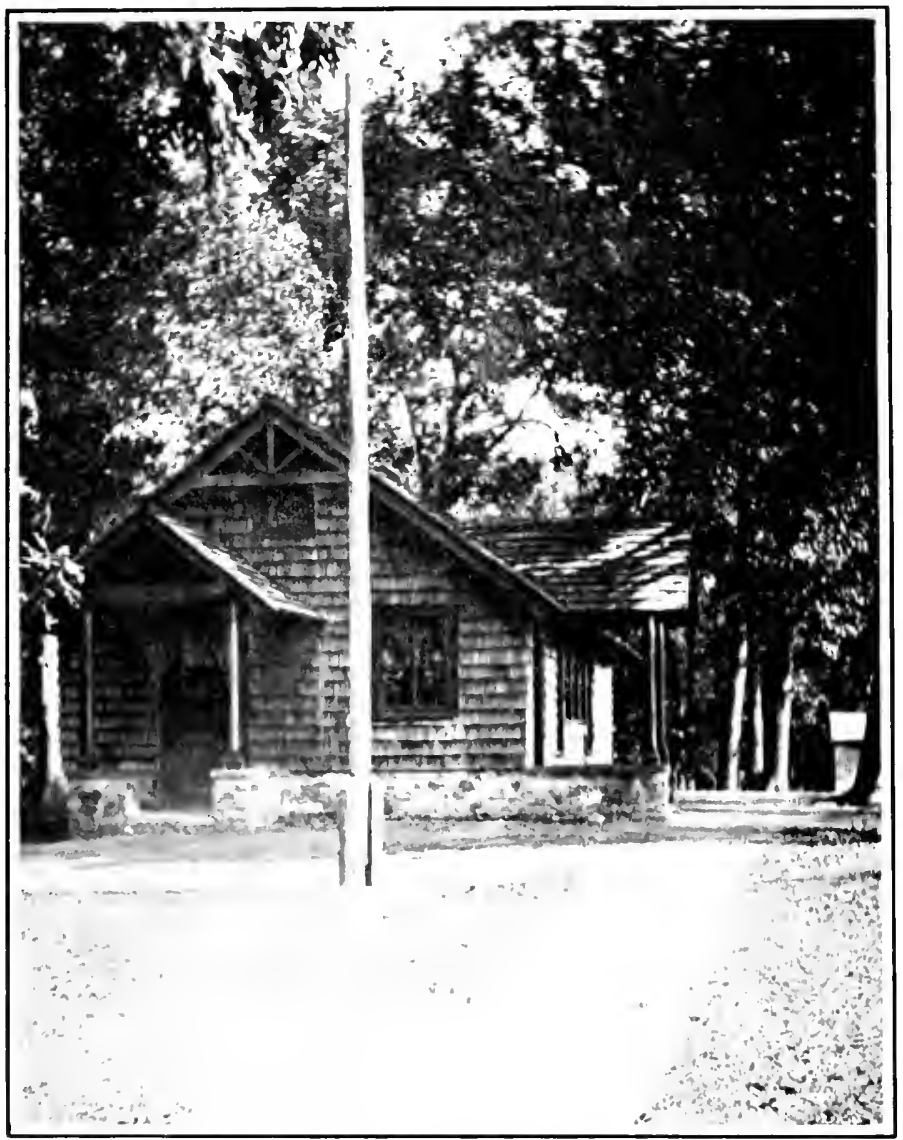

T'ATE LXXVII. THE SCHO(H-IHOLSE IN THE WOODS 


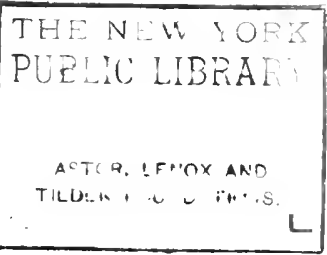


the flowers she loved best. Francis was still in New England, and he was sure it was nearer Christmas than Fourth of July. In the dream Francis was looking at a little evergreen tree and wondering if he could dig it up and take it into the house to hang his presents on. He had his bag of Japanese tools tied to his side, and when he passed again in the dream he had taken up the tree and planted it in a wooden tub to keep it from dying while he had his Christmas party. Some friends of Francis's from Herr Wilhelm Fritz's country had taught him to be very kind to trees, and also that the children in Germany carry back their evergreens after Christmas and replant them in their own places.

Francis has grown very wise, Tommy thought while he slept; perhaps before I wake up he will remember that Herr Wilhelm Fritz told us Christmas trees were already vanishing in this country, because so many thousands and thousands of them are cruelly cut down every year and thrown away.

After Francis and the evergreen-tree had passed, Tommywent on to dream and dream. He dreamed that when Christmas was over and the snow had melted, and Jack Frost had gone back to his home, spring would come again, and that a pink Hepatica would be the first of all the flowers to awake by the side of Old Adam. He dreamed that Little Trudy would be so tall and wise that she would never run away again after spring came back. He 
dreamed that Philip would love flowers more than kittens; and that Sallie would not be startled when she saw a rabbit's tall ears. He dreamed that Grandmother would have a picnic for us almost every day, and that Lucy would wave and shout at him when she saw him, instead of standing still and letting a darning-needle fly about her hand.

Tommy dreamed that he would never feel chilly after spring came again, and his caterpillar had turned into a butterfly. He dreamed that he himself was back at the school house in the woods which had been closed all summer, and that instead of reciting his lessons he was thinking about the flowers. He dreamed-but before I could remember the rest of Tommy's dream, I, too, had fallen asleep.

It was truly winter instead of Fourth of July; the flowers were asleep under the snow, and there was no more for me to tell. 


\section{INDEX TO FLOWERS}

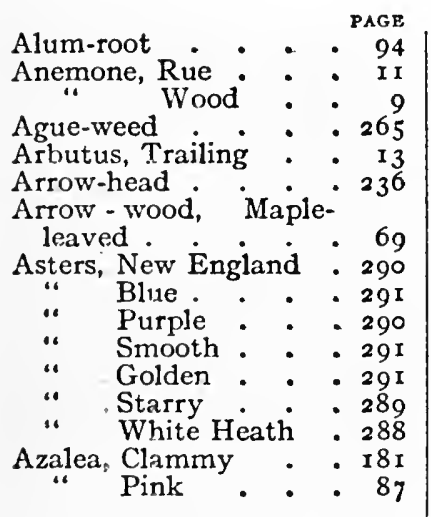

Balsam, Sweet . . 255 Baneberry, White . $\quad 32$ Bee Balm . . 183,309 Bellwort . . . 60 Perfoliate. Bergamot, Wild . 183 Birdsnest . . . 270 Bitter Bloom . . . I69 Blackberry Vines . . 139 Black Caps . . . . 140 Black-eyed Susan . . I5I Bloodroot . . . 35 Blue Eyes . . . . 5 Bluets . . . 20 Boneset . . . . . 264 Bouncing Betty . . . I84 Broom-rape, Naked . 90 Burdock . . . . 296 Butter-and-Eggs . . 233 Buttercup . . . I54 Butterflys' Banners : 12 Butterfly-weed . . 308 Button-bush . . . I96 Calico-bush . . . 145
PAGE

Campion, Starry $\quad 177,204$ Cardinal Flower “. 227 Carrot, Wild . . 270 Catchflies. . . . 177 Cat-tails . . . . 240 Chestnuts . . . 300 Chicory . . . . 309 Choke-cherry . . . 166 Cinquefoil, Common - 138 Clematis, Wild . . . 217 Clover, White Sweet 200 Cohosh, Black . . 202 Columbine, Wild : 67 Corpse Plant . . . I90 Cowslip . • • 3 I Cranesbill, Spotted . $\quad 9^{2}$ Creeper, Virginia $\quad .304$

Daisy, Michaelmas . $\quad 288$ “ Ox-eyed . . . I 5 I

Dandelion Purple - . 290 Dogbane, Spreading . I66 Dogwood, Flowering - 53 Dutchman's Breeches : 305

Elder-bush . . I I0,217 Evening Primrose, Common . . . . 307 Everlasting . . . 255

False Dragon's Tooth . 233 Farewell Summer . $\quad 288$ Five-finger . . . 138 Flag, Larger Blue - . II3 Forget-me-not . . 2 I. Foxglove, Downy False 204 Fern-leaf . 208 Frostweed . • . 285 Gentian, Blue . • 279 
Gentian, Fringed $\quad . \quad \begin{array}{r}\text { PAGE } \\ 279\end{array}$

Geranium, Wild . .92

Gerardia, Large Purple 278

Ghost Flower I6, 90, I8 7

Ginger, Wild • • $55^{\mathrm{I}}$

Globe Flower • . . 197

Goldenrods . . . $28 \mathrm{I}$

Grass, Pointed Blueeyed . . . . 108

Hawkweed • • . I94

Hepatica . . • . 5

Hickory, Shagbark . . 208

Hickory Nuts . . . 30 I

Holly, Large-leaved . $3 \circ 5$

Honey-balls . . . . 197

Honey Bloom . . . 169

Honeysuckle, Trumpet . 307

“White Swamp I80

Horsefly-weed : $:$. 215

Huntsman's-cup. . . I 48

Indian-pipe • . $\quad 90,187$

Indian Paint • • 40

"Tobacco . . 277

Indigo Broom . . . 215

Iron-weed . . . 258

Ivy, Poison . . 298, 304

Jack-in-the-Pulpit

Jamestown-weed 42, 47, I07

Jewel-weed . $\quad \cdot \quad 218$

Joe Pye-weed $: \cdot \quad 261$

Lady's Slipper, Large

$\begin{array}{rr}\text { Yellow } & \\ \text { Lady's Slipper, Smaller } \quad 73 \\ 77\end{array}$

Pink . 77

Lambkill . . . . I 45

Laurel, Great . . . I45

“ Mountain •. I45

" Sheep . . . I 45

Lily, Meadow . . . 169

"Wild Red . . . 2 Iо

“Wild Yellow . . 169

Lily, Wood . . . 2 Iо
Lily, Water, or Pond

PAGE

236, 3 Io

Lily-of-the-Valley, False ror

Live-forever . . . 256

Liver-leaf . . . 5

Lobelia, Blue . . .276

“. Great . . 276

Loosestrife, Bulb-bearing . . . . . I75

Loosestrife, Purple spiked . . . . 240

Lousewort . . . 60

Maidenhair Fern . . I 2

Maple, Scarlet • • 299

“ Silver : $\dot{8}, 299$

Marsh-marigold

May Apple . . . 90

Mayflower . . . . I3

Meadow-sweet . . I I I

Melilot, Sweet . . 200

Milfoil . . . . 264

Milkweed, Common . I2I

" Swamp • . 229

Monkey-flower . . . 198

Moth-mullen . . . 224

Mullen, Great . . . 222 “. Dock . . . 223

Oswego Tea . . . $3 \circ 9$

Phlox, Wild . • . 249

Pickerel-weed • . . 235

Pigeon-berry . . . . 295

Pink, Ground or Moss . 249

“ Rock . . . 81, I 73

“ Wild.. . 81, 173

Pinxter Flowers . . 89

Pipes . . . . . 90

Pipsissewa, Spotted . 190

Pitcher-plant . . . 147

Plantain, Snake . . . 194

Plantain, Robin's, or

Poor Robin's . . . 95

Pokeweed . . . . 294

Pond-lily, White . . 310 


\section{INDEX TO FLOWERS}

Pride-of-the-Meadow PAGB

Primrose, Common

Evening . . . 307

Prince's Pine . . . 190

Pussy Willow . . 4, 7

Quaker Ladies . . 20

Queen Anne's Lace . . 270

Queen-of-the-Meadow . I 3 I

Raspberry, Purple-flow-

ering - I 39

Rattlesnake Master : 94

Rattlesnake-weed . . I93

Red Puccoon . . . 40

Rock Bells . . . 68

Rhododendron, Bush - I33

Rosemary, White . . 288

Rose, Wild . . . I 125

" Pogonia . . . I49

Rue-anemone . • . I I

Rue, Early Meadow $\quad 82$

Rubber-plant . . 250

Saxifrage, Early . 17

Sidesaddle Flower • . 148

Silkweed, Four-leaved . 122

Silver-Leaf . . . . 219

Simpler's Joy • . 225

Skunk Cabbage : $3,4,48$

Snake-mouth . . . 449

Snakeroot, Black 93,202

Soldiers' Caps - . - I 2

Solomon's Seal . . 43, ror

" "False - IOr

Spice-bush . . . 29

Spanish Needles $\quad .296$

Spikenard, Wild . . I03

Spring Beauty . • 4 I

St. John's-wort, Com-

mon . . • • 559

St. John's-wort, Shrub-

by . . . . . 160

St. John's-wort, Smaller I60

Star of Bethlehem - • 59

Star Grass, Yellow . . 60

Starwort. . . 290
Ptrawberry, Wild

Strawberry, Wild $\cdot 24$, I 37

Succory . . . . 309

Sundew . . . 50

Sundrops.$\quad \cdot 278$

Sunflower, Wild • . 293

Sweet Fern . • • . 255

Tansy . $\cdot{ }^{\circ} \cdot 25 \mathrm{I}$

Thimble Berries . . I 39

Thorn Apple • • . 243

Thistle, Common $\quad . \quad 257$

“ Burr. • . 257

“ Roadside . . 257

“ Spear . . . 257

Tick-seeds . . . . 296

Toad Flax, Yellow • 234

Touch-me-not . . . 219

Traveler's Joy • • . 217

Trillium . . . . $4^{2}$

Trumpet Honeysuckle . 307

Trumpet-weed . . 262

Turtle-head . . . 271

Venus's Fly-trap • $\quad 49$

Vervain, Blue . . . 225

Violet, Bird's-foot . 25

"Canada.. . 25

“ Common Blue . 24

“ Dog's-tooth . . 18

“ Downy Yellow . 26

“ Early Blue . . 25

“ Sweet White . 23

Virgin's Bower . . . 2r7

Virginia Creeper. . 304

Wake-robin, Large-flowered $.42,53,59,306$

Water-Lily, White - 310

White Hearts . . . I 2

“Weed . . . I5I

“ Wreath . . . 289

Wind-flower . . . 9

Witch-hazel . . . 302

Wood-anemone . . 9

Wood Betony : . $6 r$

Yarrow, Common . . 266 


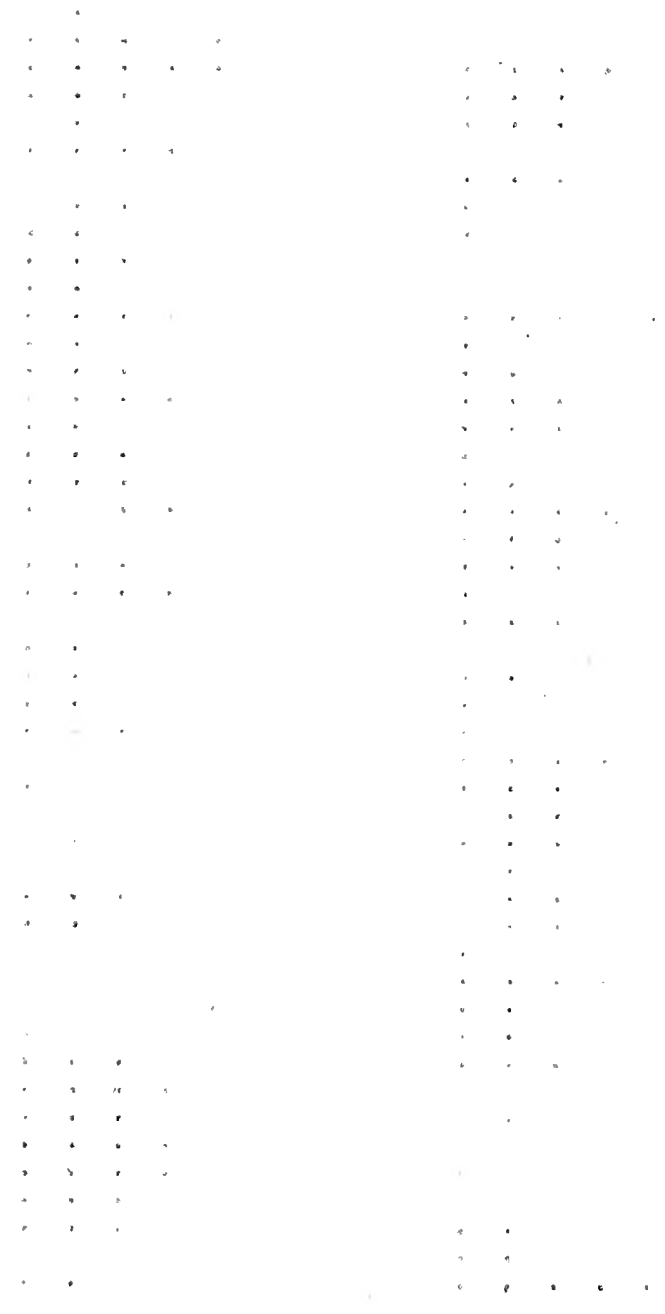


EP 






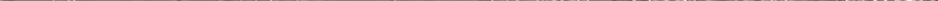

